$$
\&
$$




\section{The studies regarding monasticism and voluntary poverty in the patristic Church}

Dariusz Kasprzak OFMCap. 
Proofreading

Ewa Popielarz

Technical editor

Jadwiga Malik

The publication was financed by the subsidy for the maintaining of research potential of the Pontifical University of John Paul II in Krakow, granted by the Minister of Science and Higher Education in the year 2016.

Publikacja finansowana $\mathrm{z}$ dotacji na utrzymanie potencjału badawczego Uniwersytetu Papieskiego Jana Pawła II w Krakowie przyznanej przez Ministra Nauki i Szkolnictwa Wyższego w roku 2016.

Copyright (C) 2017 by The Pontifical University of John Paul II in Krakow

ISBN 978-83-7438-575-6 (print)

ISBN 978-83-7438-576-3 (online)

DOI: http://dx.doi.org/10.15633/9788374385763

The Pontifical University of John Paul II in Krakow Press

Poland, 30-348 Kraków, ul. Bobrzyńskiego 10

tel. (12) 42260 40, e-mail: wydawnictwo@upjp2.edu.pl

www.ksiegarnia.upjp2.edu.pl 


\section{Introduction}

The essays herein presented as The studies regarding monasticism and voluntary poverty in the patristic Church constitute a collection of the English translations of ten representative articles which since 2008 I have devoted to the theme of monasticism and voluntary poverty in the First - Fourth century Church. The individual chapters of this book were previously published in a form of articles to which I have the author's right. All of them have been thoroughly revised for the purpose of including them in this book. The research aim I had in each of my explorations was the attempt to answer the question: "What is voluntary monastic poverty in the patristic thought?" I looked for the answer in the source texts specific for the discussed subject. For that reason this book has the character of a study of theological sources with the use of the historic and theological methods.

The majority of the assumptions of the Christian theological doctrine were formed in the first centuries of the formation of the Church. The concepts then elaborated, with the lapse of subsequent centuries, started to be referred to in the Church as the theological Tradition. The theological thought of the first centuries of Christianity is equally essential for the issue of monasticism and voluntary poverty. These matters were sethen considered in the Church first and foremost in the soteriological key since it is always deciding for each Christian concept. 
6 The studies regarding monasticism and voluntary poverty...

As far as the chronological range is concerned, the stage in the history of the Christian Church, which in the Church historiography is referred to as the epoch of the Church Fathers, will be depicted. It is traditionally regarded that this period stared with the death of the last of the Apostles, that is St John the Apostle, and lasted until the death of St Isidore of Seville (AD 636) in the Western Christianity, and until the death of St John Damascene (AD 749) in the Eastern Christianity. Firstly, I will briefly present the biblical theology which was at the foundation of the contemplations of the Fathers and the first law creators, to further proceed to the most important concepts of the patristic authors up to the $4^{\text {th }}$ century concerning voluntary poverty in the patristic period monasticism.

The principal patristic reflection from the very beginning took its origin in the biblical message. The Bible represents a varied approach regarding the wealth - poverty issue. In the Old Testament wealth is unambiguously interpreted as a sign of God's blessing and acknowledged as good. Material wealth is understood as a God's gift but is only one of the elements of the full life that is promised to the believers by God (cf. Ps 23:1; Ps 34:10; Ps 37:19; Deut 16:14n). However, no sooner than in the New Testament does a clearly précised idea appear that God only is the Lord of wealth as its one and only owner and it is God that offers wealth to man (cf. 1 Cor 1:5; Eph 2:7; J 6:35; 2 Cor 8:7; 2 Cor 9:8). Material wealth interpreted as good is a thought especially characteristic for the Pentateuch in which it becomes the entitlement to nobility and the sign of God's blessing (cf. Gen 13:2; Gen 26:12n; Gen 30:43; Gen 49:1225; Deut 8:7-10; Deut 28:1-12).

Material wealth does not constitute absolute or most important good. According to the authors of the wisdom books, such goods as the peace of the soul, good name, justice, good health or wisdom are more important. In the wisdom books of the Old Testament one will notice the approach that for a Jahveh believer wealth constitutes relative and what follows from that - secondary 
good. The peace of the soul (Prov 15:16), good name (Prov 22:1), health (Eccl 30:14n), justice (Prov 16:8), wisdom (3 Kings 3:11nn; Job 28:15-19; Wis 7:8-11) are consequently given priority over wealth. The due balance between wealth and poverty is shown in the Book of Proverbs which, as an example, describes the comportment of a Jewish wise man achieved through prayer meditation: "Two things I ask of you, LORD; do not refuse me before I die: "Keep falsehood and lies far from me; give me neither poverty nor riches, but give me only my daily bread. Otherwise, I may have too much and disown you and say: 'Who is the Lord?' Or I may become poor and steal, and so dishonor the name of my God" (Prov 30:7-9).

What is more, in the prophetic writings the identification of wealth with idolatry is clearly noticeable. The damnable rich trusting foremost their material wealth reject the covenant with God (cf. Isa 2:7; Hos 2; Hos 13; Ezek 16). Yet, in the wisdom writings from the period of the Babylonian exile one finds the theme of a poor servant who trusts his God and is rewarded by him on one hand, and on the other - a rich man trusting his wealth only (cf. Isa 42:1-7; $49: 1-6 ; 50: 4-9 ; 52: 13-53 ; 12$ ). For that reason the differentiation between wealth as a sign of blessing and poverty as a sign of curse, still so well visible in the Torah but not so clear and unambiguous in the later writings, is starting to change.

Another, probably the most characteristic change in the reevaluation of the Old Testament antagonism between wealth and poverty is the evolution of the Messianic idea. Along with the collapse of the David dynasty, beside the monarchic Messianism (Messiah in the royal power of the eastern absolutistic ruler) there appeared the royal-prophetic Messianism in which the role of Messiah is given to no other but Jahveh. And he is the poor, suffering and rejected prophet sentenced to death.

The New Testament, continuing the Old Testament threads, highlights the motif of the universal salvation which is accomplished by the suffering Messiah the most. The historic Messiah 
8 The studies regarding monasticism and voluntary poverty...

as a servant of Jahveh is poor and he trusts God the Father. Jesus is the poor Messiah sent to the poor (cf. Mt 11:5; Lk 2:7; Mt 11:29; Mt 13:55; Mt 8:20; Mt 27:35). In the Gospels poverty is shown not only as a sign of trust to God but also as a sign of blessing. The Sermon on the Mount points at the poor as the blessed ones and the heirs of the Kingdom of God (cf. Mt 5:3; Lk 6:20; Ps 22:27). Moreover, spiritual poverty becomes the sign of the God's Kingdom (Jas 2:5; Lk 18:15nn; Mt 19:13-24). Poverty of Messiah and of his followers becomes an eschatological sign (cf. Lk 12:33; Mt 10:8; Mt 19:21-27; Lk 14:26-33; 1 Cor 9:18; Phil 4:11n). Never in the Bible does wealth have this power of foreseeing the eternity. Wealth - understood as the mammon, idolatry - becomes in the Messiah's teachings the prognostic of the rejection of God, of the religious impurity and injustice (cf. Lk 6:24; Mt 6:24; Mt 13:22; Lk 12:15-21; Lk 14:33; Lk 16:25; Mt 19:23; Jas 5:1-5; 1 Tim 6:17; $1 \mathrm{Jn} 2: 15 \mathrm{nn})$. Wealth carries with itself the threat of moving away from God and each Christ's follower needs to be aware of that. For that reason the original Christian community from Jerusalem, emphasizing the central role of Christ, proposes the community of material goods (cf. Acts 2:44; Acts 4:32), which is meant to constitute the sign of mutual acceptance of the members of the congregation and the spiritual union with Christ, as an ideal of the Christian life.

The early Christian authors in their considerations regarding the theme of wealth and poverty refer to biblical contemplations and continue various biblical threads themselves. In the first two centuries the strong eschatological expectation causes that wealth is for Christians a neutral and moderately relative value. In the $3^{\text {rd }}$ century, alongside with the weakening eschatological perspective, the Christian ethics regarding wealth becomes very conservative. In the predicatory teachings firm pronouncements against wealth as such start appearing and greed is especially condemn. The authors of the $3^{\text {rd }}$ century, respecting the right to private property and never speaking against it, discuss the relative moral neutrality of wealth 
and at the same time encourage the rich Christians to give bigger alms to the needy ones. The Christian Church of the $4^{\text {th }}$ century, from the moment of gaining the legal status in the Roman Empire, faces a range of new economic issues which will later be considered by many theologians and priests. However, the reference of individual Christian authors to the issues of wealth and poverty is still interpreted by themselves in the soteriological key. For that reason the introduction of specific social, economic and political doctrines on the basis of the opinions of individual Fathers and church writers of this period is incorrect. Alongside with the constantly changing socio-economic situation and with the political changes taking place in the period between the $4^{\text {th }}$ and $7^{\text {th }}$ century which affected the daily life of common Christians, soteriology becomes the perspective of Christian considerations regarding wealth and poverty.

In the essays presented below I am trying to show the understanding of ascetic poverty in relation to Christian monasticism on the basis of patristic texts. I hope that this approach will render useful for the readers. 


\section{The criteria of religion affiliation in the Christian community of the first and second century ${ }^{1}$}

The Christian community reviled amongst its followers the attitudes and doctrines which were radically different from the original consciousness already in the Old Testament. Such attitudes in the New Testament were referred to as heterodoxy/heresy since they negated completely or partially the articles of faith and the fundamental structures of religion. In the the $1^{\text {st }}$ and $2^{\text {nd }}$ century Church various groups of views formed, and their representatives, having accepted Christianity, denied consciously and voluntarily some articles of faith, accepted by the Church as the revealed truths. Gradually, their representatives were forming separate communities. In this article I am going to look into the question of how the orthodox community reacted to the heterodox views. I am going to present the reaction to heterodoxy and heteropraxy in Judaism of the $1^{\text {st }}$ century, and then in Christianity of the $1^{\text {st }}$ and $2^{\text {nd }}$ century.

\section{The criteria of orthodoxy and heresy in Judaism of the $1^{\text {st }}$ century after Christ}

In the $1^{\text {st }}$ century after Christ Judaism was not defined as a religion in terms of a doctrine which established its identity and which had

1 This article was originally published under the title: Kryteria przynależności do wspólnoty wierzacych w I-II wieku, "Analecta Cracoviensia” 40 (2008), p. 165-178. 
The studies regarding monasticism and voluntary poverty...

to be followed. Judaism of that time was defined through its relation to private and social life ruled in the tiniest details by the Law of Moses and by the ethnic affiliation to the Jewish nation. For that reason, e.g. according to P. Grech, it is better to use the term orthopraxy than orthodoxy to refer to the Jewish religion in the $1^{\text {st }}$ century after Christ, even if we find in Judaism of the time such practices (exclusion from the Synagogue) that are comparable to the later Christian excommunication (exclusion from the Church). ${ }^{2}$

In the Jewish literature of the $1^{\text {st }}$ century after Christ, the noun synagogue (Greek synagogue) meaning "the meeting, the gathering, the union of people or things" and most often referring to "the gathering of the community of Israel," 3 is the fundamental term defining the affiliation to the religious community. The Synagogue in the $1^{\text {st }}$ century after Christ constituted an important communal institution in which the elders of the Synagogue community held the religious, administrative and judicial power independently of the political community. ${ }^{4}$ Issuing the excommunication from the Synagogue acts was one of the competencies of the rabbinic courts. ${ }^{5}$

2 P. Grech, Criteri di ortodossia ed eresia nel N.T., Augustinianum 25/fasc. 3 (1985), p. 583; cf. L. H. Schiffman, At the crossroads. Tannaitic perspectives on the JewishChristian schism, [in:] Jewish and Christian self-definition, vol. 2, London 1981, p. 115156; R. Kimelman, Birkat Ha-Minim and the lack of evidence for an Anti-Christian Jewish prayer in Late Antiquity, Jewish and Christian self-definition, vol. 2, London 1981, p. 226-244.

3 M. Wróbel, Synagoga a rodzący się Kościół. Studium egzegetyczno-teologiczne Czwartej Ewangelii (J 9, 22; 12, 42; 16, 2), Kielce 2002, p. 151, points out that in Septuagint (LXX) this term appears more than 200 times, most often as a translation of the Hebrew " "êdah" (130 times) and "qāhāl" (about 35 times), meaning "the gathering, the meeting of the community." The term synagogue in LXX, however, means most of all "the gathering of the community of Israel” (cf. Lv 4:13; 22:18; Ex 12:19; Nm 16:9), and besides that it can mean the gathering of wealth or crops (Sir 31:3; Ex 34:22), or "the gathering of people, animals and things" (Jb 8:17; Lv 11:36; Is 19:6; 37:25; Jr 6:11).

4 L. I. Rabinowitz, Synagogue. First Century C. E., [in:] Encyclopaedia Judaica, vol. 15, Jerusalem (Is.) 1973, p. 581-583; R. Żebrowski, Synagoga, [in:] Polski słownik judaistyczny. Dzieje, kultura, religia, ludzie, t. 2, red. Z. Borzymińska, R. Żebrowski, Warszawa 2003, p. 596.

5 W. Tyloch, Judaizm, Warszawa 1987, p. 148-172, it emphasizes the fact that rabbinic Judaism connected with the fraction of the Pharisees, after AD 70, overtook the authoritarian 
The excommunication from the Jewish community had its origin in the discipline of the sect of Pharisees. It was also practiced by the Essenes and the Qumrans and it concerned the members of the sect who broke one of the internal laws of their group. ${ }^{6}$ As $\mathrm{M}$. Wróbel notices, on the basis of the texts from the rabbinic literature, a two-stage classification of the excommunication from the Synagogue, after the studies of P. Billerbeck, ${ }^{7}$ in the $1^{\text {st }}$ and $2^{\text {nd }}$ centuries after Christ is assumed: reprimand ("the nezifah"), ${ }^{8}$ understood as an initial stage, ${ }^{9}$ and the punishment. ${ }^{10}$ The punishment, depending on the geographical region, was graded and was treated as: the first grade punishment (in Palestine it was called "niddui" meaning to isolate, to separate, to exclude, ${ }^{11}$ in Babylon it was

leadership in the Jewish nation and set as its principal target to retain the religious-national identity of the Jews, the sign of which was the codification of the Jewish oral law (Mishnah) as well as the analysis and commentary on the Mishnah (Gemara), which together comprise the Talmud.

6 D. J. Silver, Heresy, [in:] Encyclopaedia Judaica, vol. 8, Jerusalem (Is.) 1971, p. 361. In this author's opinion, in Judaism, virtually until the Middle Ages, there were no signs of formal prohibitions concerning heresy, which would be spoken out against individuals. M. Wróbel, Synagoga a rodzący się Kościół..., op. cit., p. 179, footnote 175, read after C. H. Hunzingerem, points out that before the year 200 only a few Jewish excommunications of individuals known by name took place: Eliezera b. Hyrcanis (circa AD 90); R. Jose b. Taddai (circa AD 90 ), R. Akiba (circa AD 135), Hananiah (circa AD 140), Pelimo (circa $\mathrm{AD} 200)$.

7 M. Wróbel, Synagoga a rodzący się Kościót..., op. cit., p. 172-173; cf. P. Billerbeck, Kommentar zum Neuen Testament aus Talmud und Midrash, Bd. 4, München 1922-1928, p. 292-333.

8 The spelling of the transcription of the Hebrew terms describing the excommunication in Judaism of the $1^{\text {st }}$ and $2^{\text {nd }}$ century provided after Encyclopaedia Judaica, vol. 8, op. cit.

9 M. Wróbel, Synagoga a rodzacy się Kościół..., op. cit., p. 174, notices that "nezifah" had a form of a caution, and "shamt-a" was understood as an oral punishment, whereas "nezifah" was the kind of punishment administered by an individual on oneself. A reprimend was most often administered by a person who had an authority in the Jewish community while an individual could administer "nezifah" on oneself if he or she noticed that he/she offended a teacher or other prominent person with his or her behaviour. A reprimand was in effect for seven days in Palestine and for a day only in Babylon.

10 H. H. Cohn, Herem. In later Jewish law, [in:] Encyclopaedia Judaica, vol. 8, op. cit., p. $350-353$.

11 M. Wróbel, Synagoga a rodzący się Kościół..., op. cit., p. 176-179, points out that "niddui" was the real excommunication which was used in Palestine. The first excommunication 
The studies regarding monasticism and voluntary poverty...

so called "shamt-a" meaning to excommunicate, to exclude from the community) $)^{12}$ and the more severe one - the second grade punishment, "herem."13 The second grade excommunication ("herem") was pronounced if the "niddui" punishment was used ineffectively twice, that is after 60 days. The idea of the "herem" punishment was known in the Old Testament, ${ }^{14}$ and LXX translates the term most often as anathema. In this meaning the idea was adopted by the New Testament. ${ }^{15}$

In Judaism of the $1^{\text {st }}$ century after Christ we encounter the Jewish excommunication (in a form of a curse) codified in the liturgical formula of "Birkat ha-Minim" ${ }^{16}$ which constitutes the Twelfth

("niddui") was imposed on those Jews who did not observe the laws and traditions or ridiculed them in the community. It was preceded by three warnings.

${ }^{\text {It }}$ was in effect for 30 days, and the excommunicated person was excluded from the active life at that time, was tested and had to withdraw his or her non-orthodox views and show signs of betterment. If an individual with the niddui excommunication did not show betterment and did not withdraw his or her views, then his or her coffin was stoned after his or her death as a sign of final exclusion from the Jewish community. The Talmud lists 24 contraventions which required inflicting the "niddui" punishment. According to the oldest sources, the right to impose "niddui" was restricted to the Senhedrin, later also writers and writers' disciples had it, and in the $3^{\text {rd }}$ century also common Jews could impose it; cf. H. H. Cohn, Herem. In later Jewish law, op. cit., p. 351-352.

12 M. Wróbel, Synagoga a rodzacy się Kościót..., op. cit., p. 180, notices that the "shamt-a" was the Babylonian counterpart of the Palestinian "niddui." With this punishment some ceremonies were connected, and the formula of the Babylonian excommunication was "Let this man be excommunicated." According to some texts, it appears that the punishment was imposed by a court consisting of rabbis.

13 H. H. Cohn, Herem. In later Jewish law, op. cit., p. 351.

14 N. Lohfink, hāram, herœem, [in:] Theologisches Wörterbuch zum Alten Testament, Bd. 3, Hrsg. G. J. Botterweck, H. Ringgren, Stuttgart-Berlin-Köln-Mainz 1982, p. 192-213.

15 J. Behm, anathema, [in:] Theologisches Wörterbuch zum Neuen Testament, Bd. 1, Hrsg. G. Kittel, Stuttgart-Berlin-Köln 1990, p. 356-357; M. Wróbel, Synagoga a rodzacy się Kościót..., op. cit., p. 180-181, emphasises that the excommunication could only be administered by court and its effect was an absolute prohibition of teaching and of any economic contacts with other members of the Synagogue. As S. T. Katza claims, the "herem" punishment was a complete exclusion from the Synagogue and in the $1^{\text {st }}$ and $2^{\text {nd }}$ century was not directed against the Judeo-Christians. However, according to W. Bauer, R. E. Brown, R. Bultmann i W. D. Davies, the "herem" sanction was a complete exclusion from the Synagogue and was directed precisely against Judeo-Chrisitans.

${ }_{16}$ M. S. Wróbel, Antyjudaizm a Ewangelia według św. Jana. Nowe spojrzenie na relację czwartej Ewangelii do judaizmu, Lublin 2005, p. 195, states that the oldest text of 
Blessing of the Prayer of the Eighteen Blessings ${ }^{17}$ said regularly and commonly by the Jewes. The aforementioned blessing/curse of the heretics exists in two versions: Palestinian and Babylonian. ${ }^{18}$ The Babylonian version of the Talmud contains the word "Mosrim" (informers, traitors) instead of "Nocrim" (Nazarethians). In other parts of the Talmud we encounter another category of the cursed referred to as "Apiqoros" (so called Epicureans). A Hebrew who did not follow the Law in public and did not observe Sabbath, either due to carelessness or lack of respect, was referred to as an apostate ("Meshummad"). Such a Jew would not attain the future life but was not excluded from the earthly community of Israel. However, he was not allowed to make an offering in the Temple in

the "Birkat ha-Minim" formula was found in the genizah of the Cairo Synagogue and was dated to the $9^{\text {th }}-10^{\text {th }}$ century after Christ.

17 M. Ydit, Birkat ha minim, [in:] Encyclopaedia Judaica, vol. 4, Jerusalem (Is.) 1973, p. 1035-1036, points out that the "Birkat ha minim" formula (Hebr. "blessing concerning heretics"), most probably comes from Sir 36:7 and initially was directed against the Jews collaborating with the Hellenist-Syrian enemy during the Maccabean Revolt (then known as the prayer "Let the one who humiliates the haughty be blessed"); in the $1^{\text {st }}$ century before Christ it concerned Sadducees; The history of the creation of this formula was told in the Talmud (b Ber 28b-29a). The currently existing "B.ha.m" formula was most likely written between $80 / 90$ and 110 by Samuel the Younger by order of the rabbi Gamaliel II. The original "B.ha.m" formula was then reformed and that time directed against the Gnostic Judeo-Christians and other Jewish sects. In the Middle Ages (during the period of the Geonim) it was directed against the sinners ("poshe'im"), heretics ("apikoresim"), and apostates ("meshummadim"). M. Ydit concurs with the thesis of those scholars who claim that "B.ha.m" was never directed against non-Jews in general, but only against Jewish heretics or those, who persecuted Jews. In most variants of the reformed Judaism "B.ha.m" was modified or abandoned. More information regarding the history and variants of the "shemoneh 'esreh" blessings can be found in Thoma, A Christian theology of Judaism, New York 1980, p. 146-150.

18 In the Palestynian version of the Talmud the above mentioned blessing is: "There will be no hope for apostates. Eradicate the insolent authority immediately during our days. Let Nocerim and Minim die out immediately. Let them be erased from the Book of Life and let them not be noted together with the just ones. Blessed be you, Jahwe, who humiliate the haughty" (Polish translation: M. Wróbel, Synagoga a rodzący się Kościót..., op. cit., p. 186). While in the Babylonian version the text of "Birkat ha-minim" is as follows: "There will be no hope for the apostates; and let all Minim and Mosrim die out immediately. And root out the insolent authority and crush it immediately during our days. Blessed be you, Jahwe, who crush the enemies and humiliate the haughty" (M. Wróbel, Synagoga a rodzqcy się Kościól..., op. cit., p. 187). 
The studies regarding monasticism and voluntary poverty...

Jerusalem even though pagans could do that. The term "Minim"19 was definitely used in Palestine of the $1^{\text {st }} / 2^{\text {nd }}$ century to refer to a Hebrew who belonged to one of the sects existing on the fringes of Judaism (Judeo-Christians, Ethno-Christians, Gnostics, pagans), that did not follow the norms of rabbinic Judaism. ${ }^{20}$

Hence, the person excluded from the Synagogue, that is religiously penalized by Judaism of the $1^{\text {st }}$ century, was the one who sinned against his Jewish identity through renouncing or abandoning the Law of Moses or through not following the religion motivated by the spoken tradition of the Pharisees was. Orthopraxy was the measurement of membership in the community of Israel and its criteria were established by the rabbis who followed the tradition of the Pharisees. The case of rejecting Judeo-Christians was definitely the most interesting one as the actual reasons, legal or

19 D. J. Silver, Heresy. Heresy in the Talmud and rabbinic literature, [in:] Encyclopaedia Judaica, vol. 8, op. cit., p. 359-360; P. Grech, Criteri di ortodossia..., op. cit., p. 584, points out that in Babylon this term also refered to the pagans (or to the Christians of pagan origin), who in Palestine were referred to as "Goy". However, both in Palestine and in Babylon, one of the meanings of the Hebrew term "Min" referred to a Judeo-Christian and was often linked with Jesus of Nazareth ( $t$ Hull 2, 22.24). The "Minim" were not allowed to lead the liturgical assemblies in the Synagogues, they rarely attended them because they felt cursed and the interdict was imposed on their books ( $t$ Shab 13 [14] 5). "Apiqoros" was the semitization of the Greek term Epicurean and was used in reference to those Hebrews, who denied the possibility of God's intervention in the history of mankind. At the end of the 1st century the term could also be used in reference to Sadducees who negated resurrection and renounced the oral tradition accepted by the Pharisees. "Apiqoros" was then used in reference to all Jewish agnostics, who were materialists. The term "Nocrim," that is the Nazarethians, on the other hand, in the Talmud meant Christians ( $b$ Tanit 27b), and was used especially to refer to Judeo-Christians, as others were usually called either pagans or "Goyim." Those people were excluded from prayers in the Synagogue, they were not wanted there as the authors of the Talmud considered the Nazarethians those, who would not gain the eternal life; cf. M. S. Wróbel, Antyjudaizm a Ewangelia według św. Jana..., op. cit., p. 196-198.

20 H. Wahle, Wspólne dziedzictwo. Judaizm i chrześcijaństwo w kontekście dziejów zbawienia, Tarnów 1993, p. 67, claims that "due to that interjection in the prayer ['B.ha.m' D. K. comment] it became impossible for a Jew believing in Jesus to pray using those words or as a listener to identify with those saying the prayer aloud, by saying 'amen' as in that way he would bring bad luck on himself". In that way Christians were prevented from participating in the prayer in the Synagogue and they were excommunicated, although the words of the curse itself had never been spoken out. 
other, for which the Talmud did not allow them to participate in the prayers in synagogues and pointed at them as the ones who would not attain the eternal life, are not clear. It is possible that in the $80 \mathrm{~s}$ and 90s of the $1^{\text {st }}$ century Judeo-Christians were acknowledged by the Pharisees guiding the religiousness of Israel to be a Jewish sect which definitively rejected Judaism as such.

\section{The criteria of orthodoxy and heresy in the New Testament}

The term "the Church" itself (ekklesia) is rarely encountered in synoptic gospels (Mt 16:18; 18:17) but it often appears in the Epistles of St. Paul the Apostle and in the writings of St. John the Apostle..$^{21}$ For St. Paul the Church is the structure wanted by Jesus Christ (1 Cor 10:14-22; 11:23-33; 14:2-19), the community possessing its own rules the advocate of which is St. Paul (1 Cor 11:16). ${ }^{22}$ For St. John the Apostle the Church is the community which praises Jesus, in which all followers can possess the Spirit of truth and life (Jn 8:28-32) and take decisions through which they judge themselves (Jn 9:39; 10:19-21; Acts 1:4). It is not surprising then that first mentions concerning Christianity in the New Testament understood in communal categories of orthodoxy and heresy are encountered in the Epistles of St. Paul the Apostle and in the writings of St. John the Apostle.23

21 R. Morgenthaler, Statistik des Neutestamentlichen Wortschatzes, Zürich $1992^{4}$, p. 93, shows that the term ekklesia appeares 114 times in the New Testament: only 3 times in Mt, 23 times in Acts, but 62 times in the Epistles of Paul, 3 times in Jn, and 20 times in Apoc.

22 J. A. Fitzmyer, Teologia świętego Pawła, [in:] Katolicki komentarz biblijny, red. R. E. Brown, J. A. Fitzmyer, R. E. Murphy, tłum. i red. nauk. W. Chrostowski, Warszawa 2001, p. 2176-2183.

23 B. Vawter, Teologia giovannea, [in:] Grande commentario biblico, a cura di R. E. Brown, J. A. Fitzmyer, R. E. Murphy, ed. italiana A. Bonora et al., Brescia 1973, p. 1913-1915. 
The studies regarding monasticism and voluntary poverty...

Four fundamental criteria of the affiliation to the primal Church can be drawn from the comparison of Paul's and John's texts: 1. Jesus Christ revelation accepted by the authority of the Apostles; ${ }^{24}$ 2. the conformity to the Scriptures (i.e. to the Old Testament); 3. the argumentation showing that the opposite thesis would destroy the central position of predicting (kerygma), and 4. the presence of the Holy Spirit. The one who rejects Paul's teaching in this areais to be cursed..$^{25}$ The Greek word "anathema" conveys the meaning of the Hebrew "herem," and in the New Testament it most often means "let him be cursed" implicating so called wishes connected with the twelfth blessing "shemoneh 'esreh." ${ }^{26}$

From Paul's Epistles ${ }^{27}$ and from 1 Timothy, 2 Timothy, the Epistle to Titus and the Epistle to the Hebrews, it appears that

24 E. Szymanek, List do Galatów. Wstęp, przektad z oryginalu, komentarz, PoznańWarszawa 1978, p. 42-43 (Biblia. NT, red. E. Dąbrowski, F. Gryglewicz, t. 6, cz. 2), commenting on Gal 1:8-9, emphasizes that the truthfulness of the Gospel preached by Paul is the foundation (cf. 1 Cor 3:10) of the Churches in Galatia, and the plural "we" emphasizes the apostolic authority in preaching the Gospel. E. Dąbrowski, Listy do Koryntian. Wstęp, przekład z oryginału, komentarz, Poznań 1965, p. 150-152 (Biblia. NT, red. E. Dąbrowski, F. Gryglewicz, t. 7), commenting on 1 Cor 1:10-11, emphasizes the fundamental issue of unity and affiliation of Christians to Christ through the baptism; M. Carrez, Paolo e la chiesa di Corinto, [in:] Introduzione al Nuovo Testamento, a cura di A. George, P. Grelot, vol. 3: Le lettere apostoliche, Roma $1993^{2}$, p. 66, similarly points out that the Apostles are only the sowers and builders of God.

25 P. Grech, Criteri di ortodossia..., op. cit., p. 585; por. H. Conzelmann, 1 Corinthians. A commentary on the First Epistle to the Corinthians, [in:] AA. VV., Hermeneia. A critical and historical commentary on the Bible, Philadelphia (USA) 1975, p. 31-39; W. F. Orr, J. A. Walther, I Corinthians. A new translation. Introduction with a study of the life of Paul, notes, and commentary, [in:] The Anchor Bible, vol. 32, New York (USA) 1986, p. 244-251; G. D. Fee, The First Epistle to the Corinthians, [in:] The new international commentary on the New Testament, eds. N. B. Stonehouse, F. F. Bruce, G. D. Fee, Michigan (USA) 1987, p. $52-63$.

26 J. Behm, anathema, op. cit., p. 356-357; H. D. Betz, Galatians. A commentary on Paul's Letter to the Churches in Galatia, [in:] AA. VV., Hermeneia, op. cit., p. 5054; F. Mussner, La lettera ai Galati. Testo greco e traduzione, [in:] S. De Ausejo et al., Commentario teologico del Nuovo Testamento, Brescia 1987, p. 121-125; R. N. Longenecker, Galatians, [in:] Word Biblical commentary, vol. 41, eds. D. A. Hubbard, G. W. Barker, R. P. Martin, Dallas (Texas, USA) 1990, p. 16-18.

27 For Paul the most representative texts concerning the criterion orthodoxy/heresy are as follows: Gal 1:8-9; 1 Cor 1:10-16; 1 Cor 5:1-5; 1 Cor 15:3-8. 13-19; cf. Col 2:18; 
the Christian community, originating from Paul's recommendations, worked out a way of reacting in the face of false doctrines of faith that it encountered: 1 . if a Christian wants to follow the righteous way of faith, he needs to guard the faith entrusted to him (cf. 1 Tim 6:20), 2. he needs to study the Scriptures and draw conclusions from the liturgical life, 3 . what finds its expression in the credo formulas. 4 . If a follower behaves differently, he steps beyond the faith of the Church: in the case of a simple mistake - he gets the chance to redress it and come back to the community of believers. However, if a follower does not want to admit his guilt and reform his conduct, then he is separated from the community of faith, such a man loses his Christian identity, leaves the area where the Holy Spirit acts and enters the area of Satan's influence (cf. 1 Tim 4:1; 1:20). ${ }^{28}$

John's communities, on the basis of the writings of St. John the Apostle, also developed the criteria of orthodoxy and heresy: 1. the mystery of the eternal life, which is announced by the Son of Man, can be understood only through the Holy Spirit, that is a gift from Jesus (Jn 6:60-63);29 2. the faith is practised by the Twelve Apostles, in the name of whom Peter speaks (Jn 6:68); 3. the dissenters from faith are the disciples of Judas Iscariot who betrayed Jesus - for that reason, not to follow Jesus means to leave the Church (Jn 6:64-70); 4. not only is Jesus a Messiah but also the Son of God (Jn 8:58; $1 \mathrm{Jn} 4: 14 ; 5: 1-5)$; 5 . a schism is a sin against love (1 Jn 3:11-15). In John's schema of differentiating between the orthodox and the heretical faith, the foundation of the truth about Jesus Christ is accepting his history authenticated by an eyewitness

Heb 1:2-4; 7; Ti 1:10-16; 3:9-11; 1 Tm 1:3-11. 18-20; 6:20nn; 4:1-16; 2 Tm 1:5-18; 2:18; $4: 9-22$.

28 P. Grech, Criteri di ortodossia..., op. cit., p. 591.

29 R. E. Brown, The Gospel according to John (I-XII). Introduction, translation, and notes, [in:] The Anchor Bible, vol. 29, New York (USA) 1979², p. 295-304; R. E. Brown emphasizes that Jn 6:63 should not be understood in relation to the Eucharist but essentially in relation to the Son of Man giving the Spirit who is the God's rule of the eternal life. 
The studies regarding monasticism and voluntary poverty...

(Jn 1:1-3; 1 Jn 1:1-4). Only after is there a reference to the kerygma of primal prediction (in Pastoral Epistles it is "the deposit of faith"); to the Holy Spirit as the true "inner master" of the followers (1 Jn 4:1-4; Jn 6:45), and the last criterion of the faith differentiation is love for God and brothers in faith (Jn 2:27; 1 Jn 2:9$11 ; 3: 13)$. For that reason the term that is closest to the idea of the orthodoxy of faith in the writings of John is the idea of community - koinonia (cf. 1 Jn 1:3). ${ }^{30}$

The affiliation to the Church discussed in the New Testament from the aspect of orthodoxy is then understood as perseverance in faith of apostolic kerygma, which creates a union with the Father, the Son and the Spirit and with the Church. The criteria of orthodoxy used in the New Testament are: reference to the Old Testament, reference to the New Testament as the words of Jesus and the writings of the Apostles; the deposit of faith/kerygma of the primal prediction (in the $2^{\text {nd }}$ century it would become the so called criterion of the Tradition of the Fathers and it would be finally codified in the $5^{\text {th }}$ century by St. Vincent of Lérins), ${ }^{31}$ the authority of the Apostles, the liturgy of the Church (the later lex orandi), the professions of faith (the later Credo or regula fidei). The community

30 J. Y. Campbell, Koinōnia and its Cognates in the New Testament, JBL 51 (1932), p. 352-380; F. Hauck, koinonia, [in:] Theologisches Wörterbuch zum Neuen Testament, Bd. 3, op. cit., p. 789-810; S. Brown, Koinōnia as the basis of New Testament ecclesiology?, "One in Christ" 12 (1976), p. 157-167; R. E. Brown, The Epistle of John. Translated with introduction, notes, and commentary, [in:] The Anchor Bible, vol. 30, New York 1982, p. 170; P. Grech, Criteri di ortodossia..., op. cit., p. 593-595.

31 Vincent of Lerins, Commonitorium, 2, 2: "In view of such a number of mistakes, it is necessary to ascertain the interpretation of the prophetic and apostolic writings according to the church law and Catholic feeling. In the Church itself one should adhere to what everybody has always and everywhere believed in. Only that is truly Catholic, as the meaning of the word itself indicates, referring to universality. It will only happen when one follows universality, antiquity and uniformity,” POK 8, J. Stahr, Poznań 1928, p. 7; E. Staniek, Przekaz prawdy objawionej $w$ Kościele w ujęciu Wincentego z Lerynu, [in:] Ewangelizacja w epoce patrystycznej, red. F. Drączkowski, J. Pałucki, Lublin 1994, p. 21-24; E. Staniek, Tradycja w ujęciu Wincentego z Lerynu, [in:] T. Dzidek, B. Sieńczak, J. D. Szczurek, Tradycja w Kościele. Materiały z sympozjum zorganizowanego przez PAT, PTT, IT CM w Krakowie, Kraków 1994, p. 67-78. 
of faith that lives according to the above mentioned criteria - lives in "koinonia" and keeps love. The New Testament gives then the germs of elements which in the 2nd century would be used to differentiate between heresy and orthodoxy. ${ }^{32}$ A person who does not perceive the criteria of orthodoxy contained in the New Testament (it concerns mainly the writings of St. Paul and St. John), does not live in "koinonia" and for that reason is considered a public sinner and church punishments are inflicted on him (deprivation of office, church privileges, and finally exclusion from the Church). The exclusion from the Church showed a tragic paradox: the excommunicated ones did not fulfill their fundamental communal vocation as constituting one body through faith and baptism, they did not participate in one bread - in the Eucharist. ${ }^{33}$

\section{The criteria of orthodoxy and heresy in the Church of the $2^{\text {nd }}$ century. Ignatius of Antioch, Justin Martyr, Irenaeus of Lyons}

In the letters of St. Ignatius of Antioch, not much later than John's canonical writings, one constantly hears the Antiochian successor of St. Peter the Apostle's calling Christians to: believe in the truth of Christ's incarnation and resurrection and to dissociate themselves from judaizing the Christianity. ${ }^{34}$ Those encouragements

32 P. Grech, Criteri di ortodossia..., op. cit., p. 595-596.

33 R. Sobański, Chrzest jako podstawa jedności Kościoła, Warszawa 1971, p. 113-131. The author comes to the conclusion that in the $1^{\text {st }}$ century Church it was believed that people who were baptized are to live in the community. "The community is the way of life of the baptized. The New Testament community is not a social group - that is the Church - but the relationship between the members of the group, that is of the Church. The mystery of the Church itself is touched on: the Church lives in the community. The community is the Church's mission. That is the will of the Founder," ibid., p. 116-117.

34 Ignatius of Antioch, Do Kościoła w Smyrnie 1-3: Schriften des Urchristentums, 1 [further as: SUr 1], Hrsg. J. A. Fischer, Darmstadt 1998, p. 204-207; BOK 10, Pierwsi 
The studies regarding monasticism and voluntary poverty...

were always accompanied by absolute condemnation of the opponents, and their mistakes were classified as heresy. ${ }^{35}$ The term heresy itself has a technical meaning in Ignatius' writings, which proofs the consolidation of the category of heresy in the Christian communities at the beginning of the $2^{\text {nd }}$ century. ${ }^{36}$

For Justin Martyr heresy was a false doctrine about God or a doctrine about godless conduct, which originates from Satan's inspiration $^{37}$ and some borrowings from the pagan philosophy. ${ }^{38}$ Heretics develop heresy by passing their teachings from the master to the disciple, similarly to what schools of philosophy did with their teachings, and for that reason Justin compares the heretic succession (diadoche) to the philosophical succession. ${ }^{39}$ Hence, heresy is for Justine a distortion of Christianity and a promotion of views contrary to Christ's recommendations. ${ }^{40}$

świadkowie. Pisma Ojców Apostolskich, tłum. A. Świderkówna, red. M. Starowieyski, Kraków 1998², p. 136; Do Kościoła w Magnezji 8-10: SUr 1, p. 166-169; BOK 10, p. 121122; Do Kościoła $w$ Efezie 7, 1; 16, 2: SUr 1, p. 146; 154; BOK 10, p. 115; 117; Do Kościoła $w$ Filadelfii 6, 1: SUr 1, p. 198; BOK 10, p. 133.

35 Ignatius of Antioch, Do Kościoła $w$ Tralleis 6, 1-2: SUr 1, p. 176; BOK 10, p. 125; Do Kościoła $w$ Smyrnie 6, 2; 7, 1: SUr 1, p. 208; 210; BOK 10, p. 13-138; Do Kościoła $w$ Magnezji 8, 1: SUr 1, p. 166; BOK 10, p. 121-122.

36 M. Simonetti, Ortodossia ed eresia tra I e II secolo, Messina 1994, p. 23, 23-24, footnote 32, shows that Ignatius of Antioch, to mark his opponents of faith, uses the term heterodoxein (e.g. To Smyrnees 6, 2) and the term eterodoxia (e.g. To Magnesians 8, 1). While the Christian use of the term orthodoxein and orthodoxia is later, most likely only since the time the writings of Eusebius of Caesarea were created (264-340). Hence, the concept of the orthodoxy of faith itself was expressed much earlier than the term orthodoxy appeared. In the $1^{\text {st }}$ and $2^{\text {nd }}$ century to refer to the true faith (orthodox) the following were used: the true faith, the doctrine or mercy.

37 Justine Martyr, Apologia I, 26: PG 4, p. 271-273; POK 4, tłum. i red. A. Lisiecki, Poznań 1926, p. 31-32; Justine Martyr, Dialog z Żydem Tryfonem 35, 2: PG 4, p. 365; POK 4, p. 155-156.

38 Justine Martyr, Dialog z Żydem Tryfonem 35, 6: PG 4, p. 366-367; POK 4, p. 156-157.

39 Justine Martyr, Dialog z Żydem Tryfonem 49, 6: PG 4, p. 383-384; POK 4, p. 181; 52, 3: PG 4, p. 386; POK 4, p. 186; 82, 1: PG 4, p. 425-426; POK 4, p. 250; 103, 3-4: PG 4, p. 447-448; POK 4, p. 285-286; 139, 4: PG 4, p. 487; POK 4, p. 347; Justine Martyr, Apologia I, 32, 1: PG 4, p. 277-278; POK 4, p. 36-37; I, 32, 8: PG 4, p. 279; POK 4, p. 38. Cf. A. M. Javierre, El tema literario de la sucesion. Prolegómenos para el estudio de la sucesion apostolica, Zürich 1963, p. 402-406 (Biblioteca Theologica Salesiana, I, 1).

40 A. Le Boulluec, La notion d’hérésie dans la littérature grecque IIe-IIIe siècles. T. I. De Justin à Irénée, Paris 1985, p. 37-91. 
The fact that the Roman Church rejected marcionism as a doctrine (theological dualism: the God of the Old Testament - the just demiurge and the creator of the world and the God of the New Testament - the highest and good, Christ's Father; docetism concerning Christ; accepting the New Testament only and negating the Old Testament) became another stepping stone in the formation of the catholic orthodoxy. The Church categorically rejected the Marcion's erroneous views, interpretation of the doctrine of faith which could have become the universal interpretation in the Christianity of the time. Excluded from the Christian community, Marcion did not change his views and did not convert to the proper faith but definitively separated himself from the catholic Church and gave its beginning to the Marcionist church. ${ }^{41}$

Another essential step on the way to differentiation between orthodoxy and heresy and to asserting the fact of affiliation to the Christian religious community was the series of norms established by St. Irenaeus from Celtic-Roman Lugdunum (later French Lyons). ${ }^{42}$ Ireaneus made the Church sensitive to doctrinal differentiation between the true Christian doctrine and the heresy of Gnosticism in various forms ${ }^{43}$ - well disguised by superficial rhetorical similarities. The Bishop of Lugdunum uses the term heresy (airesiv) 8 times to refer to the views which are contradictory to the "rule of the truth," while the term heretic (airetokon) appears 52 times in his writings. ${ }^{44}$ Generalizing a number of Irenaeus' antiheretical statements, in each Gnostic heresy he ponders, three fundamental motives of heresy can be pointed out: 1. a blasphemy against the Creator (in a sense that each heresy is a type of devilish apostasy from God, an act of submitting oneself

41 M. Simonetti, Ortodossia ed eresia tra I e II secolo, op. cit., p. 29-33.

42 A. Benoit, Irénée et l'hérésie. Les conceptions hérésiologiques de l'évêque de Lyon, "Augustinianum" 20 (1980), p. 55-67.

43 K. Koschorke, Die Polemik der Gnostiker gegen das kirchliche Christentum, Leiden 1978.

44 B. Reynders, Lexique comparé du texte grec et des version latine, arméninne et syriaque de l'Adversus Haereses de Saint Irénée, CSCO 142, Louvain 1954. 
24 The studies regarding monasticism and voluntary poverty...

to devil's temptation, a denial of the Scriptures and a deprivation), 2. the negation of the salvation of the body, 3. lack of acceptance of the Word incarnation. ${ }^{45}$ The central point of the dispute between the Christian orthodoxy and the Gnostic heresy was the interpretation of the Bible (especially the interpretation of the Prologue of John - Adv. Haer. III, ${ }^{46}$ of gospel parables - Adv. Haer. IV ${ }^{47}$ and 1 Cor 15:50 (essential in the discussion about the salvation of body) - Adv. Haer. V). ${ }^{48}$

According to Irenaeus' view, the evil of heresy in Chistianity lies in the fact that: 1 . heresy deforms Christian faith received from the Apostles (on the pretext of: gnosis, purgation and correction of faith); 2. heresy rejects "the rule of truth" either fully or selectively, it divides the Bible; under the pretext of purgation of faith it rids the Scriptures of those ideas, which are not in accordance with the rules of the given heresy (and in effect it leads to doctrinal divisions and divisions of the whole Church); 3. heresy breaks the communion (koinwni6a) with the Spirit, the Church and creates its own universe, however, without communion. ${ }^{49}$

Irenaeus defines Christian orthodoxy through: 1. the rule of truth ("regula veritatis") provided during baptism; ${ }^{50}$ 2. the proof from the Scriptures ("ostensio ex Scripturis") justified on the basis of the Tradition and the apostolic succession passed by bishops'

\footnotetext{
45 Y. De Andía, L’hérésie et sa réfutation selon Irénée de Lyon, Augustinianum 25/ fasc. 3 (1985), p. 610-611.

46 Irenaeus of Lyons, Adversus haereses III: FChr 8/3, Hrsg. N. Brox, Freiburg 1995.

47 Irenaeus of Lyons, Adversus haereses IV: FChr 8/4, Hrsg. N. Brox, Freiburg 1995.

48 Irenaeus of Lyons, Adversus haereses III: FChr 8/5, Hrsg. N. Brox, Freiburg 2001.

49 Y. De Andía, L’hérésie et sa réfutation selon Irénée..., op. cit., p. 611, 644; while E. Peretto, Criteri do ortodossia e di eresia nella Epidexis di Ireneo, Augustinianum 25/fasc. 3 (1985), p. 666, analyzing Irenaeus' Epidexis lists four criteria differentiating between the Christian orthodoxy and the Gnostic heresy: 1. the apostolic Tradition as the fundamental criterion of the evangelical truth standing above the Church and Scriptures; 2. the continuation of the Revelation and the continuation between the Old and New Testament; 3 . the rule of faith; 4. the continuum of autonomy and freedom of a human being, also in a state of sin.

$50 \quad$ J. N. D. Kelly, Early Christian creeds, London $1964^{4}$, p. 76.
} 
holy orders ${ }^{51}$ the harmony ("consonantia") between the theological thought and the Eucharist; 4. the union of faith compared with the multiplicity of heretical systems; 5 . truth compared to mistake; 6. the integrity of the Bible and the body of the Church compared with the multiplicity of heresy; 7. the kerygma of faith included in the apostolic Symbol; 8. the fact that the Bible is canonical in the Church; 9. the apostolic tradition based on the apostolic succession (the Episcopal letters of Church in Rome are the example). ${ }^{52}$

The measure of affiliation to Christianity in the $2^{\text {nd }}$ century was then the common criterion of orthodoxy and orthopraxy defined by the Christian community. The final punishment, which was administered since the times of St. Paul the Apostle in relation to people considered to be heretics, after a few admonitions, encouragements to betterment in behaviour and calls for the unity with the Church (cf. 2 Thess 3:15), was exclusion from the unity with Church, that is excommunication (cf. 2 Cor 2:5-8). The Church did not consider any sinners to be irretrievably lost. On the other hand, however, since the apostolic times it had seen the necessity of excluding from the community the Christian who did not believe in the Christian way and did not behave in the Christian way. ${ }^{53}$ Also, as the Fathers and Christian writers of the $1^{\text {st }}$ and $2^{\text {nd }}$ century stated, those who do not fulfill the duties imposed on them by the holy baptism $^{54}$ are to be avoided, as the heterodox Christians become

51 B. Sesboüé, La preuve par les Écritures chez saint Irénée. À propos d'un texte difficile du livre III de l'Adversus Haereses, "Nouvelle Revue Théologique" 103 (1981), p. 872887; M. Simonetti, Per typica ad vera. Note sull'esegesi di Ireneo, "Vetera Christianorum" 18 (1981), p. 357-363.

52 Y. De Andía, L’hérésie et sa réfutation selon Irénée..., op. cit., p. 643-644; more about the meaning of heresy in the writings of St. Irenaeus of Lyons in: A. Le Boulluec, $L a$ notion d'hérésie dans la littérature grecque IIe-IIIe siècles. T. I. De Justin à Irénée, Paris 1985, p. 113-188.

53 B. Löbmann, Die Exkommunikation in Neuen Testament, Theologisches Jahrbuch, Leipzig 1965, p. 446-458.

54 Didache 5, 2: SUr 2, Hrsg. K. Wengst, Darmstadt 1998, p. 74, 76; BOK 10, p. 37; Didache 14, 2: SUr 2, p. 86; BOK 10, p. 39; Didache 15, 3: SUr 2, p. 88; BOK 10, p. 40; List Barnaby 19, 2: SUr 2, p. 186, 188; BOK 10, p. 197. 
26 The studies regarding monasticism and voluntary poverty...

the false brothers promoting heresy ${ }^{55}$ the dissenters and traitors to the Church. ${ }^{56}$ The writers of the Church of the $1^{\text {st }}$ and $2^{\text {nd }}$ century recommended praying for the sinners' repentance and return, as leaving them outside the community hurt the Christian unity, ${ }^{57}$ calling on the dissenters to return to the community, ${ }^{58}$ not losing hope that they would repent, ${ }^{59}$ as, as long as they live, they have a chance to confess and repent. ${ }^{60}$

\section{Conclusion}

The Christian Church of the $1^{\text {st }}$ and $2^{\text {nd }}$ century was already conscious of being a community of believers. The criteria of membership developed gradually and frequently only incidentally. Consequently it is still too early to speak of a developed problem of orthodoxy/orthopraxis or heterodoxy/heteropraxis. The basic criteria of being a member of the Christian Church in the $2^{\text {nd }}$ century were as follows: the belief in Jesus Christ corroborated by baptism, a sincere will of belonging to the Church of true believers in Christ, and a duty to live in agreement with the high moral standards. If a Christian man or woman broke the principles observed by the community, he/she was successively removed from the Church community of the faithful, and had to remain out of the Church until he/she again converted to the true faith. The similarities between the Christian excommunication and Jewish herem are clearly visible. A heterodoxy was regarded as sinful (a lack of unity with the church) and

\footnotetext{
55 Polycarp of Smyrna, List do Kościoła w Filippi 11, 4: SUr 1, p. 262; BOK 10, p. 160.

56 Hermas, Pasterz 72. (6) 4: SUr 3, Hrsg. U. H. J. Körtner, M. Leutzsch, Darmstadt 1998, p. 290, 292; BOK 10, p. 266.

57 Clement of Rome, List do Kościoła $w$ Koryncie 46: FChr 15, Hrsg. G. Schneider, Freiburg 1994, p. 176-179; BOK 10, p. 72.

58 Polycarp of Smyrna, List do Kościoła $w$ Filippi 11, 4: SUr 1, p. 262; BOK 10, p. 160.

59 Ignatius of Antioch, Do Kościoła $w$ Efezie 10, 1: SUr 1, p. 148, 150; BOK 10, p. 116.

$60 \quad$ Homily from the 2nd century 8, 3: SUr 2, p. 248; BOK 10, p. 95.
} 
consequently must have been a painful experience of isolation from one another on both sides, orthodox and heterodox. 


\section{II}

\section{The idea of poverty in the first to third century Church*}

The contemporary exegesis of the historical-critical current and the current examining the theological significance of biblical texts has shown that not a single New Testamental text provides a base for determining the state of consecrated life in the form it was successively undertaken, defined and institutionalized in the Church. ${ }^{1}$ As Jean-Marie Roger Tillard OP aptly observed, "Gospel demands that all of us give a radical answer; it guarantees divine grace to everyone, to reach fulfillment greater than this ideal in the neverending search for the overcome; for 'perfection' is Christian life itself as depicted [in Gospel]."2

* This article was originally published under the title: Idea ubóstwa w Kościele pierwszych trzech wieków, "Analecta Cracoviensia” 42 (2010), p. 255-268.

1 J. Hering, La première Epître de saint Paul aux Corinthiens, Paris 1949, p. 56-57; J. Dupont, Mariage et divorce dans L'Evangile, Paris 1959, p. 191-220; S. Légasse, L'appel du riche, contribution à l'étude des fondaments scripturaires de l'état religieux, Paris 1966, p. 184-245; J. M. R. Tillard, Autorité et vie religieuse, "Nouvelle Revue Théologique» 88 (1966), p. 786-806; Q. Quesnell, Made themselves eunuchs for the kingdom of heaven, “The Catholic Biblical Quartelry” 30 (1968), p. 335-358; J. M. R. Tillard, Le fondement évangélique de la vie religieuse, "Nouvelle Revue Théologique" 101 (1969), p. 916-955; A. Dumas, Colloque sur le célibat. Célibat et sexualité, Paris 1970, p. 69-75; J. W. Glaser, Commands-Counsels, a Pauline teaching?, "Theological Studies” 41/2 (1970), p. 275-287; J. M. R. Tillard, La pauvreté religieuse, "Nouvelle Revue Théologique” 102 (1970), p. 806848, 906-941; M. R. Tillard, Le propos de la pauvreté et l'exigence évangélique, "Nouvelle Revue Théologique” 110 (1978), p. 202-232, 359-372.

2 J. M. R. Tillard, Consigli evangelici, [in:] Dizionario degli istituti di perfezione [further as: DIP], vol. 2, a cura di G. Rocca, Roma 1975, p. 1671. 
The studies regarding monasticism and voluntary poverty...

Hence, traditional concepts of Evangelical Counsels - which assume two-track Christianity - are a rather ascetical construct that came into being as a result of a spiritual interpretation referring to the life and preaching of Jesus Christ, but which were not directly expressed by Him. The concept of the so called Evangelical Counsels came into life not earlier than in the second half of the $3^{\text {rd }}$ century, together with the genesis of Christian Monasticism, and settled only in the $12^{\text {th }}$ century. ${ }^{3}$ The synthesis of its doctrine was initiated by St. Thomas of Aquin ${ }^{4}$ and developed by St. Francis de Sales, ${ }^{5}$ but had not fully appeared as an interpretation of the monastic life before the Second Vatican Council (Lumen gentium 43-44; Perfectae caritatis 12-14). ${ }^{6}$ Therefore, when it comes to renunciation of possession and collective property, analogies provided by biblical texts may not be identified with the subsequent phenomenon of voluntary poverty. ${ }^{7}$

3 J. M. R. Tillard, Davanti a Dio e per il mondo. Il progetto dei religiosi, Roma 1977, p. 367-413.

4 A.-I. Mennessier, Conseil (Don de), [in:] Dictionnaire de Spiritualité, vol. 2, Paris 1953, p. 1584-1592; A.-I. Mennessier, Conseils Évangéliques. 4. Saint Thomas d'Aquin, [in:] Dictionnaire de Spiritualité, vol. 2, op. cit., p. 1599-1607.

5 A.-I. Mennessier, Conseils Évangéliques. 5. Saint François de Sales, [in:] Dictionnaire de Spiritualité, vol. 2, op. cit., p. 1607-1609, 1599-1607.

6 E. Gambari, Życie zakonne po Soborze Watykańskim II, tłum. J. E. Bielecki, Kraków 1998, p. 120-121; cf. Życie konsekrowane w dokumentach Kościoła od "Vaticanum II" to "Vita consecrata", red. B. Hylla, Kraków 1998.

7 Cf. J. Jeremias, Jerusalem zur Zeit Jesu, Göttingen 1962³; J. Jeremias, Die Gleichnisse Jesu, Göttingen-Zürich 1996 ${ }^{11}$; L. E. Keck, The poor among the saints in Jewish Christianity and Qumran, "Zeitschrift für die neutestamentliche Wissenschaft" 57 (1966), p. 54-78; J. Dupont, Les béatitudes, vol. 1-3. Paris 1969-1973; R. Batey, Jesus and the poor, New York 1972; L. Schottroff, W. Stegemann, Jesus von Nazareth - Hoffnung der Armen, Stuttgart 1978; J. Sobrino, Relation de Jésus avec les pauvres et les déclassés. Importance de la morale fondamentale, "Concilium" 150 (1979), p. 23-34; D. L. Mealand, Poverty and expectation in the Gospel, London 1980; W. Stegemann, Das Evangelium und die Armen, München 1981; E. Lohse, Das Evangelium für die Armen, "Zeitschrift für die neutestamentliche Wissenschaft und die Kunde der älteren Kirche” 72 (1981), p. 51-64; R. Schnackenburg, Nauka moralna Nowego Testamentu, tłum. F. Dylewski, Warszawa 1983, p. 47-49. 
However, in the Old and New Testament there are contents that since the second half of the $3^{\text {rd }}$ century have become a point of reference in the formation of the doctrine of poverty consecrated in the womb of Christian coenobitism. Thanks to a critical study of source texts - both biblical and patristic in their theological and literary-historical aspect - a literal interpretation of certain source texts is avoided, because in the past there was frequent abuse of ideological interpretations. Instead, the focus is on approaching eligible conclusions that are elicited from Revelation and its theological interpretations in the history of the Christian community.

Hence, contemporary theology defines Evangelical Counsels as ascetic means to revealing the form of life of Jesus Christ in the life of a consecrated person and as means to individual sanctification. Therefore, the concept of consecrated poverty is described in spiritual theology as a radical form of life assumed voluntarily, according to one's personal vocation and based on renunciation of private possession. ${ }^{8}$

Is the aforementioned concept of consecrated poverty reflected in the original Christian tradition? In this article, I wish to examine biblical texts to which classical interpretations of the counsel of poverty refer, but expressed from the point of view of historicalcritical exegesis and a historical development of poverty doctrine. My analysis will be narrowed down to the first three centuries, as they are considered the most significant to the development of Christian doctrine.

Firstly, I shall discuss New Testamental teaching juxtaposed with a propagated ideal of consecrated poverty, followed by the most important forms of patristic interpretation of evangelical poverty, and finally I will depict a patristic interpretation of the poverty of Jesus Christ (first to fourth centuries).

8 S. Légasse, Povertà, 1: Dati biblici e interpretazione teologica della povertà di Cristo, [in:] DIP, vol. 7, a cura di G. Rocca, Roma 1983, p. 248-249. 
32 The studies regarding monasticism and voluntary poverty...

\section{New Testamental preaching and the ideal of consecrated poverty}

The formation of the idea of poverty, understood as an incentive flowing from the preaching of the Gospel, was a gradual process. Christ's benediction from Mt 5:3 does not say anything about any philosophical or ascetic virtues adopted on account of the Messiah authority nor about a promise of eternal life in exchange for it. Yet, it does point to the fact that precedes the meeting with Jesus, i.e. the state of the inner self already present in a blessed person. "Blessed are the poor in spirit", paradoxically they already are so, even before meeting Jesus. ${ }^{9}$

In the context of the basic Gospel message of eschatological awaiting the Parousia, there was the preaching of evangelical catechesis about vigilance and bearing fruit (Mk 4:18-19; Mt 6:1934), about the search for real treasure (Mt 6:19-21), about the lack of compromise between God and wealth (Mt 6:24), about the encouragement to give the money to the poor and follow Christ (Mt 16:24-28) as well as a didactic message about the young man being challenged to reach Christian perfection (Mt 19:16-22). As Simon Légasse OFMCap. observed, the appeal directed towards the wealthy young man ( $\mathrm{Mk}$ 10:17-22 and par) points to the fact especially by Mt 19:16-22 - that Jesus directs an individual appeal to some people, which obliges them to leave everything behind and follow the Messiah. ${ }^{10}$

This is one of the evangelical paradigms in which all Christians may find themselves summoned by Christ and may undertake an individual endeavour to follow Christ, with all - even the most radical - consequential implications deriving from such an activity. The message about the wealthy young man - Mt 19:16-22 - long

\footnotetext{
E. Bianchi, Povertà e ricchezza nella Bibbia, "Servitum" 6 (1972), p. 277-309.

10 S. Légasse, Povertà, op. cit., p. 250.
} 
existed and was interpreted in spiritual theology as a foundation for the now historical classical distinction between commandment and counsel, or else between regular demands of the Christian life and demands of the perfect life. ${ }^{11}$ However, the classical interpretation, presented by the aforementioned Elio Gambari SMM, does not reach beyond regular references to selective quotations that corroborate his standpoint (chiefly from St. Augustine of Hippo and Thomas of Aquin) all the same ignoring the rest of Tradition and the aforementioned study of contemporary historical exegesis and the history of theology.

A strong emphasis should be put on the fact that there is only one perfection in the Evangelical message tradition with which Christ appeals to all Christians. The reality of blessings (Mt 5:1-11) calls for perfection greater than the one passed on by the Law of Moses; nevertheless, it is the call directed to all believers in Christ. ${ }^{12}$ For that reason, the Christian community may not be solely identified with the poor, but it shall show solidarity with the poor and aggrieved..$^{13}$ The Gospel is the new Law that binds the human being together with God in the New Covenant ratified through the blood of Christ and His Resurrection. Hence, the classical differentiation between commandment and counsel may no longer be theologically justified. The evangelical summons show a huge portion of God's dynamism, which presupposes a new life in God.

11 Such a distinction, was cited as valid in his case study by E. Gambari, Życie zakonne po Soborze Watykańskim II, tłum. J. E. Bielecki, Kraków 1998, p. 121, where he stated that "The differentiation between commandment and counsel is justified in New Testament, specifically in the invitation directed to the wealthy young man (Mt 19:21), and in Jesus' statement about refraining from marriage 'for the Kingdom in Heaven' (Mt 19:12). Both texts express exactly what Paul calls 'counsel' (1 Cor 7:40)."

12 J. Du Plessis, Teleios, the idea of perfection in the New Testament, Kampen 1959; S. Légasse, L'appel du riche..., op. cit.; B. Häring, The normative value of the Sermon on the Mount, "The Catholic Biblical Quarterly" 29 (1967), p. 375-385; R. Schnackenburg, Nauka moralna Nowego Testamentu, Warszawa 1983, p. 47-48.

13 R. Schnackenburg, Sittliche Botschaft, Freiburg-Basel-Wien 1988, p. 293. 
34 The studies regarding monasticism and voluntary poverty...

God aids the realisation of the New Covenant in Christ, therefore the Gospel demands that everyone give a radical answer of faith and appeals to all faithful to achieve perfection. The Christian life itself is rendered perfect, in the form it was passed on by the Gospel of Matthew and parallel texts ${ }^{14}$.

Thereupon the contemporary exegesis of the text of Mt 10:1622 compared with Mk 10:17-22 and Lk 18:18-23 does not allow for the classical differentiation between commandment and counsel. The evangelical reality described by Matthew, influenced by the human writer, adopts a form of a didactic dialogue, nota bene to all Christians, in which the evangelist Matthew appeals to all to take the effort of approaching perfection.

Perfection is the aim of the Christian life (comp. Mt 5:48); the evangelist emphasises that it is necessary to abandon earthly goods as they may constitute a source of scandal or a threat to a successful get through to the real aim (Mt 5:29-30; 18:8-9). There are no reasonable grounds to consider an institutional interpretation of Christ's appeal; the evangelist simply desires that the believers' faith in the Saviour was guaranteed in the best way possible. No conclusions about a potential exaltation of the followers of Christ should be drawn either; they are obliged to perfection just as the rest of Christians, as well as to choosing all necessary means to achieve the desired aim. ${ }^{15}$ Significantly, none of the canonical Gospels uses the word "poor" to describe Jesus or his disciples. The Apostle Paul will be the first one to use the term. ${ }^{16}$

\footnotetext{
14 S. Légasse, L'appel du riche..., op. cit., p. 113-124.

15 S. Légasse, L'appel du riche. Contribution à l'étude des fondements scripturaires de l'état religieux, p. 113-124,184-196; S. Légasse, Richesse, [in:] Supplément au Dictionnaire de la Bible, fasc. 5-6 (1982), p. 645-687; cf. S. Ormanty, Bóg albo pieniądz. Wymagania Kościoła pierwotnego od katechumenów na podstawie perykopy Mk 10, 17-31, "Studia Gdańskie" 17 (2004), p. 5-22.

16 J. Galot, Le fondement évangélique du voeu religieux de pauvreté, "Gregoriana" 56 (1975), p. 441-467; M. Del Verme, La comunione dei beni nella comunità primitiva di Gerusalemme, "Rivista Biblica" 23 (1975), p. 353-382.
} 
The events described by Luke in the catechesis of the Apostles subsequent to the evangelical catechesis - depict exemplar ideas of collective property and brotherly love of the first community in the idealised vision of the community of Jerusalem (Acts 2:42-44; 4:32). The ideal of the Christian community's poverty was significantly encouraged by the anticipated end of the world. Those who renounced their earthly goods, exchanged them into cash and offered to the Eleven for the needs of the community of Jerusalem, were soon to obtain heavenly goods from the Christ descending on clouds. ${ }^{17}$ Luke's ideal of the apostolic poverty was implemented in the early Church, in the Jerusalem community ${ }^{18}$ (Acts 4:34-37) and to this very ideal, sprouting from literal interpretations, will the Cenobites later refer in their works. ${ }^{19}$

It seems that other early Church communities did not share Luke's visions about collective poverty; no references were made to potential acts of disposing of or selling goods and assembling money at the feet of the Apostles of the Resurrected, neither in communities of Corinth nor Ephesus nor Rome. With the end of the world anticipated soon, the Apostle Paul preached about distancing oneself from the world's virtues, material goods and marriage (1 Cor 7:24-40); but most of all, in the light of the end of days, he called for pure faith and not coming into conflict with God through any form of idolatry (cp. Rom 1:25; Col 3:5; Eph 5:5). Nevertheless,

17 J. Hadot, L'utopie communautaire et la vie des premiers chrétiens de Jérusalem, [in:] Problèmes d'Histoire du Christianisme, vol. 3, Bruxelles 1972-1973, p. 15-34; L. T. Johnson, The Acts of the Apostles, vol. 5, Collegeville (Minnesota) 1992, p. 89-93 (Sacra Pagina Series); J. A. Fitzmyer, The Acts of the Apostles, vol. 31, New York 1998, p. 312-327 (The Anchor Bible).

18 F. Gryglewicz, Egzegeza dziejów Apostolskich (ch. 4-8), [in:] Materiaty pomocnicze do wykładów z biblistyki, t. 4, red. S. Łach et al., Lublin 1979, p. 63-95; B. Witherington III, The Acts of the Apostles. A socio-rhetorical commentary, Grand Rapids (Michigan) 1998, p. 204-213; G. Rossé, Atti degli Apostoli. Commento esegetico e teologico, Roma 1998, p. 224-227; J. K. Pytel, Księga Dziejów Apostolskich. Problemy literackie i wybrane tematy teologiczne, [in:] Księga Dziejów Apostolskich, red. J. K. Pytel, Szczecin 1999, p. 21-65.

19 Cf. P. C. Bori, Chiesa primitiva. L'immagine della comunità delle origini - Atti 2, 42-7; 4, 32-7 - nella storia della Chiesa antica, Brescia 1974. 
The studies regarding monasticism and voluntary poverty...

he never differentiated between a high and low station of Christian life nor between a first and second class Christian. Instead, he appealed to all Christians with the pledge of constant effort towards achieving the aim of meeting and living with Christ (1 Cor 2:6; 3:12; 13:1-10; 14:20; Col 1:28; Eph 4:13; Phil 3:12-15), irrespective of the advancement of their faith; he appealed to beginners - who were often compared to children - as well as those who were fully mature in faith.

In this effort, everyone should remain devout and aware of the fact that achieving the aim of faith is possible only with the help from God and the Holy Spirit. ${ }^{20}$ Therefore, once and for all, according to the New Testament, the poor are those who humbly conform to God and confide in Him at life's trials; these are given salvation and live in the community of the Saviour's disciples. ${ }^{21}$

\section{Forms of patristic interpretations of evangelical poverty}

Jean Gribomont OSB observed that the lack of a clear-cut model of evangelical poverty in the early Church gave grounds - in the history of Christian spirituality - to the formation of different ascetic attitudes towards possession and making use of material goods. ${ }^{22}$ The following forms of experiencing the poverty encouraged by the New Testamental catechesis were characteristic in the period of patristicism:

- a form of naturalistic - sometimes even cynic - rejection of modern goods with attempts to confine oneself to what

20 S. Lyonet, La vocation chrétienne à la perfection selon saint Paul, [in:] Laïcs et vie chrétienne parfaite, vol. 1, Rome 1963, p. 15-32.

21 J. M. R. Tillard, Le propos de pauvreté et l'exigence évangélique, "Nouvelle Revue Theologique" 100 (1978), p. 207-232, 359-372; S. Légasse, Richesse, [in:] Supplément au Dictionnaire de la Bible, fasc. 5-6 (1982), p. 645-687.

22 J. Gribomont, Povertà, [in:] DIP, vol. 7, op. cit., p. 245. 
was offered by nature (this is not the kind of life Jesus led, but an appeal from Mt 6:25-34 to some ascetics like Eustatians or Messalians seemed to suggest such a model; today's exegesis points out that the appeal in Mt 6:25-34 does not encourage idleness but is a warning against preoccupying one's mind solely with the matters concerning attire and food. It is, at the same time, a reminder of the necessity to combine work with the deep belief in God's endless virtue);

- a form of begging in the name of God, entrusting one's spirituality to God and relying on benefactors (Jesus and His community lived off the contributions of rich Israelite women; later on, analogously to the life of Jesus and the Apostles, the first forms of keeping the early priesthood appeared, followed by the state of material upkeeping in the early Church of consecrated widows);

- the form of living from the Apostolic work, with an additional, voluntary contributions from the evangelized (Jesus, the Twelve and the Apostle Paul provided for themselves in that way; the form afterward institutionalized as tithes or church tax);

- the form of paid work in connection with apostolate, known to be adopted by the Apostle Paul; work would be meagre if it could be abandoned at any time or place in order to undertake Acts; any surplus from the income not spent on supporting oneself would be given to the poor;

- the form of ascetic renunciation of personal property, in order to create a Christian form of social communism. This ideal at the end of the third century entered the Church through the - at that time - uprising Cenobite movement and was adopted as their own. The ideal was based on a Utopian and charismatic vision from Acts 2:44-45 and 4:32. It had not been known or commonly accepted in the Church of Apostolic times. If we assume that the Acts of the Apostles 
The studies regarding monasticism and voluntary poverty...

were written early, we may reason that the text came into being before the death of the Apostle Paul, e.i. before the years 64-67. However, other hypotheses point to more intermediate datation of the years $80-85$ or even later, into the beginning of the 2nd century. According to father Jean Gribomont OSB early Christian monasticism referring to Acts 2:44-45 talked less about the poverty as such while highlighting the distance between earthly goods and the form of a private life without private possession. ${ }^{23}$

Christian asceticism of the first three centuries in the East did not express itself in the radical renunciation of earthly goods. Most of the converted to Christianity belonged to a poor social class to whom the distinction between subsistence level and measurable economic income was rarely recognizable and mostly blurred. The difference between the poor and the poor Christians was that the latter believed in Kingdom of God in connection with eschatological hope for something better in the future world, which simultaneously relativized the value of the earthly economic conditions. Also, the practice of fraternal love, which for Christians constituted a measurable guarantee of social security. ${ }^{24}$

\section{Patristic Interpretation of Christ's poverty (First to Fourth Centuries)}

Early Christian authors always admitted that Jesus had lived in poverty, however the understanding of what this poverty could exactly mean stirred up all sorts of theological controversy among Christians. In the history of theology, two periods of debates on

\footnotetext{
23 J. Gribomont, Povertà, op. cit., p. 246-248.

24 J. Gribomont, Povertà, 2: In Oriente, [in:] DIP, vol. 7, op. cit., p. 253; A. Kalsbach, Armut. II B. Christlich, [in:] Reallexicon für Antike und Christentum [further as: RAC], Bd. 1, Hrsg. Th. Klauser Stuttgart 1950, p. 707-709.
} 
the poverty of Jesus resulted from this interpretational controversy. The first one occurred during the patristic period and the second one in the Middle Ages. ${ }^{25}$ Both provided answers to the notion of the poverty of Jesus and both constituted sources of reference for future generations.

Writers and Church Fathers of the first three centuries referred to the text of 2 Cor 8:926 when talking about the perfect poverty. In it, Paul pointed to Christ's exemplar behaviour of appealing to

25 J. Leclercq, Les controverses sur la pauverté du Christ, [in:] Études sur l'histoire de la pauvreté, vol. 1, éd. M. Mollat, Paris 1974, p. 45-55. The Middle Age dispute over the understanding of poverty and the relationship between ownership and using possessions among Franciscans - also among the Friars Minor - as well as the disputes over the dominican and papal interpretations (later based on Thomas of Aquin's lectures), lead to a gradual absolutization of the concept of the monastic life. According to Franciscan theologians the socalled perfect state could only be reached by people abiding by the monastic Regula. Though monks themselves could be perfect and imperfect, the rest of Christians (Pope, bishops, lay people - therefore the believers not abiding by the monastic Regula) could be perfect, but were unable to live in the state of perfection, as perfection was guaranteed not by the Gospel, but a "proper" interpretation of it, the so-called Regula. Consecrated poverty in this monastic concept of perfection was interpreted as participation in God's kingliness (understood as God's, King's, Christ's humiliation through incarnation and the embrace of living in poverty). Therefore, living in voluntary poverty was to be the most effective means of participating in God's kingliness. According to St. Bonaventure (Apologia pauperum), and later also according to a huge crowd of Franciscans, the highest stage of perfection could be reached by strictly practicing poverty. On the other hand, according to Thomas of Aquin, paricular forms of ascetic practices (poverty among very many of them) should be evaluated in relation to the specific purpose for which a monastery was formed. The higher the purpose, the higher the state of perfection of a monastery. Therefore, as Thomas of Aquin points out, not necessarily a poorer monastery is a more perfect one; a more perfect monastery is the one whose poverty is adjusted to the monastery's particular common purpose (ST II-II, q. 188, a. 7. ad. 1-2). Pope John XXII rejected the Franciscan interpretation of poverty on the basis of Thomas of Aquin's theses, and in the bulla Quorumdam exigit from 1317 confirmed pope Clemens V's decision, all the same obliging Franciscans, especially Spirituals, to obedience to the pope. Twenty five of them refused, were handed over to Inquisition, and four of them were burnt at the stake in Marseille on 7 May 1318. Those disputes gradually led to a division in the Franciscan Order into Friars Minor and Conventual Franciscans. More on this subject, see the study of J. Łopat, Wilhelma Ockhama "Opus nonaginta dierum" jako epigońska i desperacka obrona ideału franciszkańskiego ubóstwa w XIV wieku, "Lignum Vitae” 10 (2009), p. 11-58.

262 Cor 8:9: "For you know the generous act of our Lord Jesus Christ, that though he was rich, yet for your sakes he became poor, so that by his poverty you might become rich," $\mathrm{BT}^{4}$ (Biblia Tysiąclecia, Polish translation of the Bible). 
The studies regarding monasticism and voluntary poverty...

faithful Corinthians for voluntary generosity towards the fellow faithful from the Jerusalem community who were in urgent need and who could not support themselves with the work of their own hands. This text is a good example of how far from reality Luke's Utopian Ideal from Acts 2:44-45 became around the years 55-56 (hypothetical time of the creation of 2 Cor written in Macedonia) and that collecting alms became necessary in the Christian world of the time, so that the once exemplary Jerusalem community could survive materially. ${ }^{27}$

Jean Gribomont points out that the texts from the $2^{\text {nd }}$ century, e.g. Didache and ascetic letters known as Pseudo-Clementines might reflect an intermediate stage in the idea of voluntary Christian poverty between the tradition of Early Christianity and the later monastic one of the fourth century. In this tradition of the $2^{\text {nd }}$ and $3^{\text {rd }}$ century ascetic poverty would be related to the life of poor nomadic Christian teachers and prophets. They would live off the hospitality of communities where no regular and stable priesthood existed. Poverty of such Christian preachers would be reflected in living in accordance with evangelical norms as well as norms which are not to be found directly in the Gospel, without the privilege of real property or income. Yet, in the aforementioned texts, we may also discern early threats of overusing the idea of poverty; nomadic preachers sometimes used to push the hospitality of local communities to their financial limits on their way to securing basic needs, all the same setting a poor example for the hosts. ${ }^{28}$ If encouraging words of maintaining material poverty are not found in New Testament, they surely are present in the aforementioned Pseudo-Clementines. There, we encounter early traces of preaching which, in the name of heterodoxically construed purity of faith,

27 J. Leclercq, "Il s'est fait pauvre". Le Christ modèle de pauvreté volontaire d'après les Pères, "La Vie Spirituelle" 117 (1967), p. 501-518.

28 J. Gribomont, Povertà, 2: In Oriente, op. cit., p. 254. 
popularized hatred towards material goods, highlighting their universally sinful nature. ${ }^{29}$

However, at the same time, the theology of positive wealth developed, represented best by Clement of Alexandria (born in 155, died in 212). In his work, "Who is the Rich Man That Shall Be Saved?," he spoke against the tendencies of Encratites and ascetic rigorists, who after the year 170 became more gnostic than Christian in their views (to return to the state of the so called early perfection, they rejected all forms of corporeality, understood as evil, especially sexual and nutritional; hence, they rejected marriage, procreation, eucharistic wine but also benefiting materially from using personal property).$^{30}$ Clement made efforts to prove that material wealth does not undermine the quality of Christian life, whereas poverty itself does not ennoble the faithful..$^{31}$ Above all, one should be free from one form of wealth in particular, i.e. passion. ${ }^{32}$

29 Pseudo-Klemens, Homilia, 15,9: PG 2, 364 A.

30 Cf. G. Sfameni Gasparo, Enkrateia e antropologia. Le motivazioni protologiche della continenza e della verginità nel cristianesimo dei primi secoli e nello gnosticismo, SEA 20, Roma 1984, p. 22-322.

31 Clement of Alexandria, Who is the rich man that shall be saved, 11: "Sell your possessions. And what is this? He does not, as some conceive off-hand, bid him throw away the substance he possessed, and abandon his property; but bids him banish from his soul his notions about wealth, his excitement and morbid feeling about it, the anxieties, which are the thorns of existence, which choke the seed of life. For it is no great thing or desirable to be destitute of wealth, if without a special object not except on account of life. For thus those who have nothing at all, but are destitute, and beggars for their daily bread, the poor dispersed on the streets, who know not God and God's righteousness, simply on account of their extreme want and destitution of subsistence, and lack even of the smallest things, were most blessed and most dear to God and sole possessors of everlasting life. Nor was the renunciation of wealth and the bestowment of it on the poor or needy a new thing; for many did so before the Saviour's advent, some because of the leisure (thereby obtained) for learning, and on account of a dead wisdom; and others for empty fame and vainglory, as the Anaxagorases, the Democriti, and the Crateses" (http://www.newadvent.org/fathers/0207.htm).

32 Clement of Alexandria, Who is the rich man that shall be saved, 12: "And what peculiar thing is it that the new creature the Son of God intimates and teaches? It is not the outward act which others have done, but something else indicated by it, greater, more godlike, more perfect, the stripping off of the passions from the soul itself and from the disposition, and the cutting up by the roots and casting out of what is alien to the mind. For this is 
The studies regarding monasticism and voluntary poverty...

The first Christian Eremites, like Paul the Hermit (born in 228, died in 341) or Anthony the Great (born in 250/251, died in 356) already considered optional abandonment of private possessions, retreating to the desert - area with no landlords or any material significance - and limiting own material needs to minimum. Despite legendary cases of being fed by angels and living under the open sky in the desert, the fact is that the first monks did have some limited private possession and work was an obligatory necessity; also, caring for old and sick monks compelled them to possess measurable financial means (to supply medicine, medical care and administration of real estate). Neither could they complain from the lack of benefactors. ${ }^{33}$

The first Father of the Church, referring to 2 Cor 8:9, was Hilary of Poitiers (died in 367), who pointed to the fact that Jesus became a poor man to enrich the human race by giving it salvation. ${ }^{34}$ Likewise did the remaining Fathers in the $4^{\text {th }}$ century, among them Ephrem the Syrian (died in 373), Basil of Caesarea (died in 379), Ambrose Bishop of Milan (died in 397), and Augustine of Hippo (died in 430). Jean Leclercq, analysing their texts, noticed ${ }^{35}$ that it had been Augustine, a bishop in North African Hippo Regius who, in the Sermon 239:6, had collated 2 Cor 8:9 with Phil 2:6-8 to demonstrate that Christ's devotion to God, up till the death of the

the lesson peculiar to the believer, and the instruction worthy of the Saviour" (http://www. newadvent.org/fathers/0207.htm). More about Clement's understanding of wealth and poverty see: H. Dal Covolo, L'episodio del giovane ricco in Clemente e Origene, [in:] Per foramen acus. Il cristianesimo antico di fronte Alla pericope evangelica del "giovane ricco", Milano 1986, p. 79-108; J. Pałucki, Dobre bogactwo. Chrześcijaństwo wobec dóbr materialnych - stanowisko Klemensa Aleksandryjskiego, Lublin 1992, p. 3-24.

${ }_{33}$ J. M. Lozano, The doctrine and practice of poverty in Early Monasticism, "Claretianum" 16 (1976), p. 5-32.

34 Hilary of Poitiers, Tractatus in Psalmum, CXXXIX, 13: "Lord Incarnate was poor. According to the Apostle he became poor to enrich the man. The One, that apart from his body had nothing else in the world. And for our salvation, He wished to be born of a virgin for our salvation. The Lord of Heaven had no silver, nor fields, nor herds." CSEL 22, 788 (own transl.).

35 J. Leclercq, Povertà, op. cit., p. 252. 
cross, was the realization and manifestation of Jesus' absolute destitution. This was the product of God's love, who created this world (Jn 1:3), and who wanted to be the Creation in the universe He created, so that the man He created did not lose himself. Therefore, God impersonates a carnal body and forbears the time of incarnation. ${ }^{36}$ According to the bishop of Hippo, the aim of this humiliation in becoming a man was clearly soteriological, and not in the least charitable. God humiliated Himself to be born a man, so that the man could receive Him and be restored in the Kingdom of Heaven. ${ }^{37}$

In the patristic tradition, up to the $4^{\text {th }}$ century, Church Fathers and Writers highlighted two forms of Christ's poverty: poverty of nature and factual poverty. Poverty of nature was the poverty of the Incarnation of the Son of God. The multifariously manifested poverty of Jesus Christ was only a simple sign and the demonstration of the fundamental poverty of Christ's nature. Church Fathers, talking about Christ's poverty, highlighted the fate of the human nature after having been separated from God and expelled from the garden of Eden. Namely, it became poor and meagre, with all its limitations and imperfections, and as such - poor, meagre, limited and imperfect - it became the very human nature of the Son of God through His incarnation. It emerged in the form of suffering, pain, humiliation, contempt, rejection and finally, humiliating death of the cross. ${ }^{38}$

36 Augustine of Hippo, Sermon, 239, 5.6: NBA 32/2, a cura di P. Bellini, F. Cruciani, V. Tarulli, Roma 1984, p. 626; more about the mistery of humiliation of the Incarnate God, see the case studies of: R. Arbesmann, Christ the "Medicus Humilis" in St. Augustine, “Traditio" 10 (1954), p. 1-28; G. Remy, Le Christ médiateur dans l'oeuvre de Saint Augustin, vol.1-2, Lille-Paris 1979; B. E. Daley, A humble mediator. The distinctive elements in Saint Augustine's christology, "Word and Spirit" 9 (1987), p. 100-117; M.-A. Vannier, Creatio, Conversio, Formatio chez s. Augustin, Fribourg 1991.

37 Augustine of Hippo, Sermon, 239, 5.6: "Here is His wealth, here is his poverty: for you the wealth was created, for you was the poverty that brought you back home. As He, being seemingly poor, was hospitably received, kindness was given to those, who could receive Him, and not misery to the one in need.” NBA 32/2, 626 (own transl.).

38 J. Leclercq, "Il s'est fait pauvre"..., op. cit., p. 501-518; J. Leclercq, Povertà, op. cit., p. 251-252. 
44 The studies regarding monasticism and voluntary poverty...

\section{Conclusion}

The classical interpretation of Mt 19:16-22 had long been a norm for acknowledging vows and, later, the counsel of poverty. However, parallel texts Mk 10:21 and Lk 18:23 point to a specific case, which might have been exemplary, but from which it is difficult to develop a general doctrine of consecrated poverty. Similarly, the Apostles forsake all things to follow the Master from Nazareth (Mk 10:28 and par). In the above, we may discern a particular outline which, over time, will be explicated in the Christian ascetic tradition.

In the New Testamental texts, we do not find a clear, straightforward opinion about what, in the Church tradition, will become known as counsel of voluntary poverty. New Testamental texts indicate, though, that every and each Christian may reach perfection in Christ, living their own lives under the charisms received from the Holy Spirit. According to the preaching of the New Testament, the poor are those, who humbly conform to God, entrust all to Him in life's trials, as only such are given salvation and live in the community of disciples of the Saviour.

The early patristic tradition, based on the Evangelical Preaching, developed different forms of experiencing poverty, such as naturalistic, begging in the name of God, living from the Apostolic work, the form of paid work in connection with apostolate, and ascetic renunciation of personal property. Since the end of the third century, in the Egiptian Monasticism, the last model of poverty had rooted. Nevertheless, it was only practiced by cenobites. Whereas on the outskirts of Christianity, at the turn of the second century, there existed some radical, heterodoxical groups (the Encratites radical nomadic prophets and preachers), which preached their own - far from evangelical - teaching about condemnation of material goods (sinful in their material self), and postulated their prohibition within Christian communities (Pseudo-Clementines). Early Christians (first to third century), in their interpretation of 
evangelical catechesis, did not find a radical renunciation of goods a necessary component of faith. Most of them were already from poor environments, and what made them stand out was their faith in the Kingdom of God and their brotherly love.

It was at the turn of the third century that Christ started to be referred to as "poor," in the true sense of the word. Never had Jesus been called "poor" in the Gospels, therefore the early Christian writers developed their thoughts on the basis of 2 Cor 8:9. Up to the fourth century, the patristic tradition referring to the poverty of Christ, highlighted the soteriological aspect of God's Incarnation; the second person of the Blessed Trinity humiliated Himself by becoming a man to fully receive him and return him to His Father's Kingdom in Heaven. The Church of the first three centuries did not find in the Gospels the so called evangelical counsels, therefore, did not recognize any two-track way to salvation (according to the so called counsels - fast and radical, and according to the commandments - slower and ordinary). For the Christians of the first three centuries, Jesus Christ, whose words were passed on and commented on in the Tradition of the first three centuries, spoke universally to the whole community and to each and every Christian. 


\section{III}

\section{Rites of passage during monastic initiation in the early monastic rules*}

Mircea Eliade noted that the initiation elements of the Early Christianity arose from the fact that initiation is a dimension that coexists with every re-evaluation of the religious life. One can experience a superior state of existence and participate in permeating of holiness to the world or history only through death in the lay and benighted world which and through rebirth. ${ }^{1}$ If we find very few traces of initiation scenarios and vocabulary, apart from baptism and the Eucharist, in the Early Christianity, it is because the Christian Mystery is God's mystery, or, in other words, God's plan to save man through his son, Jesus Christ. Jesus tells his disciples about the mysteries of the Kingdom of God. Jesus' message therefore already contains the initiation structure; but it does not mean that the Early Christianity was influenced by Hellenistic mysteries. ${ }^{2}$ As M. Elide further observes, from the $3^{\text {rd }}$ century onwards, with the expansion of Christianity, this paradigm of salvation, in order to be available for the whole humankind, had to be expressed in a commonly understood language. In the case of a religious language,

* This article was originally published under the title: Obrzędy przejścia podczas inicjacji monastycznej $w$ starożytnych regułach zakonnych, [in:] Katechumenat i inicjacja chrześcijańska w Kościele starożytnym, red. P. Szczur et al., Lublin 2011, p. 139-173.

1 M. Eliade, Inicjacja, obrzędy, stowarzyszenia tajemne. Narodziny mistyczne, tłum. K. Kocjan, Kraków 1997, p. 169.

2 M. Eliade, Inicjacja, obrzędy, stowarzyszenia tajemne..., op. cit., p. 169-170. 
The studies regarding monasticism and voluntary poverty...

symbols performed such a function. Consequently, the Christian language became enriched with archaic symbols, with initiation imagery and themes that originated from the Mysteries, and with elements that came to being as a result of the assimilation of Greek philosophy. Between the $3^{\text {rd }}$ and the $4^{\text {th }}$ century, these borrowings became very popular in religious language of the Christians, though, it cannot be said that the content of the Mysteries was totally incorporated. The fundamental sense of the ecclesiastical teachings remained solely Christian. ${ }^{3}$

Anthropologists and sociologists define religious initiation as an entry, introduction, induction into the mysteries of religion through religious ceremonies and rituals or through secular rituals connected to a certain extent with religion. ${ }^{4}$ Initiation rites and rituals introduce a person into a new life, which frameworks are strictly defined by a given community. Once the rituals are done, the person is transformed, is born anew, and acquires new status in the community. The community also changes its attitude towards the person initiated. ${ }^{5}$ It accepts the presence of the initiated in its group, which leads to personalisation and socialisation of the novice. ${ }^{6}$ The

$3 \quad$ M. Eliade, Inicjacja, obrzędy, stowarzyszenia tajemne..., op. cit., p. 171-172; cf.: A. D. Nock, Hellenistic mysteries and Christian sacraments, "Mnemosyne" 4/5 (1952), p. 117-213; H. Rahner, The Christian mysteries and the pagan mysteries, [in:] The mysteries. Papers from the Eranos yearbooks, vol. 3, New York 1955, p. 337-401; H. Rahner, Griechischen Mythen in christlicher Deutung, Zürich 1957.

4 J. Baniak, Inicjacja religijna, [in:] Religia. Encyklopedia PWN, t. 5, red. T. Gadacz, B. Milerski, Warszawa 2002, p. 32-33.

5 E. Leach, Kultura i komunikowanie, [in:] Rytuat i narracja, tłum. M. Buchowski, Warszawa 1989, p. 81-83; J. Baniak, Inicjacja religijna, [in:] Leksykon socjologii religii, red. M. Libiszowska-Żółtkowska, J. Mariański, Warszawa 2004, p. 153.

6 According to W. Piwowarski (Socjologia religii [The sociology of religion], Lublin 1996, p. 225-229) every religious ritual performs three functions: 1) it concentrates on sacrum (thus establishing, maintaining and strengthening ties with sacrum; 2) it strengthens ties between people on the religious plane; finally, 3) it leads to moral transformation, both individually and socially. Furthermore, the participation in religious rituals (according to T. F. O'Dea, The sociology of religion, Englewood Cliffs [NJ]1966, p. 13-16; W. Piwowarski, Socjologia religii, op. cit., p. 229-230) has the following social effects: 1) the possibility of consolation and reconciliation in a group; 2) it provides emotional basis for security and 
concept of religious initiation is widely used in the contemporary Church to explain Christianity, ${ }^{7}$ and not only to interpret the sacraments $^{8}$ and sacramentals ${ }^{9}$ (including monastic profession), ${ }^{10}$ but also to describe the participation in new religious movements. ${ }^{11}$

Religious initiation is a particular form of rites of passage. The rites of passage (French rites de passages) were defined by a French ethnologist and a specialist in religious studies, Arnold van Genepp (1973-1957)..$^{12}$ He provided an important classification of rites and described how they function. According to Genepp, there are two

newly emerged identity during the period of transformation; 3) it sustains values of the established society; 4) it contributes to integration of personality by depicting the ultimate; 5 ) it is connected with the growth and maturing of an individual, it helps him/her to overcome the obstacles. For more see: W. Piwowarski, Socjologia rytuatu religijnego. Zarys problematyki, "Roczniki Nauk Społecznych" 11 (1983) 1, p. 5-84.

7 See also a number of articles devoted to Christian initiation in both the early Church and in the largest contemporary Christian denominations, comprised in Przekroczyć próg Kościoła. Tydzień eklezjologiczny 2005, t. 6, red. K. Mielcarek et al., Lublin 2005, p. 13-123 (W Trosce o Kościół).

8 The Second Vatican Council, Konstytucja o liturgii świętej - Sacrosanctum Concilium, 65, 71; Polish edition: red. J. Groblicki et al., Poznań 1967³, p. 56, 57; Dekret o działalności misyjnej Kościoła - Ad gentes divinitus, 14; Polish edition: p. 449-450; Dekret oformacji kaptańskiej-Optam totius, 8, 11, 14, 16, 21; Polish edition: p. 291, 293-294, 295, 296-297, 299; Dekret o apostolstwie świeckich - Apostolicam actuositatem, 30; Polish edition: p. 402-403; A. Nocent, Iniziazione cristiana, [w:] Nuovo Dizionario di Liturgia, a cura di D. Sartore, A. M. Triacca, Roma 1984, p. 678-695; M. Qualizza, Inicjacja chrześcijańska. Chrzest, bierzmowanie, eucharystia, tłum. M. Stebart, Kraków 2002; B. Nadolski, Inicjacja chrześcijańska, [in:] Leksykon liturgii, red. B. Nadolski, Poznań 2006, p. 543-550.

9 W. Piwowarski, Socjologia religii, op. cit., p. 209-210, trying to come up with a typology of rituals, classifies them into four categories: religious rituals, aesthetic rituals, civil rituals, rituals of cycles and life crises. The religious rituals are further divided by Władysław Piwowarski into four groups: a) rituals of a liturgical year, called annual rituals; b) rituals connected with sacraments; c) rituals connected with sacramentals.

10 J. Nemry, Manual de iniciación progresiva a la vida religiosa. Postulantado y noviciado, Zaragoza 1960; O. Schmucki, Iniziazione alla vita francescana alla luce della Regola e di altre fonti primitive, "Italia Francescana" 60 (1985), p. 27-50, 398-426.

11 Cf.: R. Blazquez, Wspólnoty neokatechumenalne. Ocena teologiczna, a joint translation, Lublin 1989; K. McDonnel, G. T. Montague, Inicjacja chrześcijańska a chrzest $w$ Duchu Świętym. Świadectwo z pierwszych ośmiu wieków, tłum. M. Górnicki, W. Kustra, Kraków 1997.

12 A. van Gennep, Obrzędy przejścia. Systematyczne studium ceremonii, referring his analyses to primitive or quasi-civilised societies, stated that the importance of these rites justifies singling out a special category - the rites of passage. These can be further subdivided 
The studies regarding monasticism and voluntary poverty...

essential criteria along which the rites of passage are divided: gender criterion (men belong to one group and women to the other) and magico - religious criterion (the profane vs. the sacred). These two criteria apply to all societies in any part of the world and at any point of history. ${ }^{13}$

Subsequent anthropologists employed the concept of the rites of passage to analyse modern society and then they extended it to describe any form of a known society. Currently the idea of rites is a theory that is used to describe the change of status in human societies. ${ }^{14}$ All rites of passages, also the historical ones, are characterised by a structure that comprises three phases: 1 . the separation phase that consists of rituals separating an individual from their current group; 2 . the transition phase that consists of symbolic acts towards the subject remaining outside the "normal" society; 3. the incorporation (reaggregation) phase that consists of the subject re-entering society with a new status or role (this rite mirrors the opposing rite of separation). ${ }^{15}$

Analysing the content of the ancient monastic rules, we come across characteristic rituals that introduced a candidate for monkhood into the monastic community. Further stages of monastic initiation were supposed to increase the candidate's commitment to God and to the monastic community as well as to separate the candidate from common Christians and to incorporate him into the community of the Chosen Ones - the monks. That is why the stages of monastic rituals can be regarded as the rites of passage in the

into: the rituals of exclusion (separation), the rituals of the transitional stage (marginal) and the rituals of incorporation (integration), thum. B. Biały, Warszawa 2006, p. 36.

13 A. van Gennep, Obrzędy przejścia..., op. cit., p. 186.

14 Cf.: Rites of passage, eds. J. Holm, J. Bowker, London 2004; D. Davies, Introduction. Raising the issues, [in:] Rites of passage, op. cit., p. 3; R. A. Rappaport, Rytuat i religia $w$ rozwoju ludzkości, a joint translation into Polish, Kraków 2007, p. 296-297; W. A. Haviland, D. Walrath, H. E. L. Prins, Cultural anthropology. The human challenge, Belmont 2008, p. 309; L. M. Hopfe, M. R. Woodward, Religions of the world, New Jersey 2009, p. 27.

${ }_{15}$ J. Baniak, Inicjacja religijna, [in:] Religia. Encyklopedia PWN, t. 5, op. cit., p. 33. 
religious ritual of the ascetic commitment to God..$^{16}$ In this article, I employ Arnold van Gennep's classification of the rites of passage during religious initiation to describe the rites of monastic initiation in the first monastic rules of the Early Christianity. In the sociological research, the concept of the rites of passage is used to examine the milestones in the life of an individual. These important moments are examined from a social rather than personal perspective. The present historical-theological analysis focuses on the rites of passage in the early monastic rules to demonstrate the theological and historical importance of these rites to both the monastic community and to specific individuals, that is to ancient monks.

I examine the rules most characteristic of ancient Christian Coenobitism: the Rule of St Pachomius (written in Coptic before 347 ; only the third of the original text survived and only the half of the Greek translation was preserved in fragments $;{ }^{17}$ the complete text exists in Latin, it is a translation done by Hieronymus from Stridon in 404); ${ }^{18}$ the Greater and Lesser Monastic Rules of

16 A. van Gennep, Obrzędy przejścia. Systematyczne studium ceremonii, claims that the catholic rites of passage to monkhood have both permanent elements that follow either the Roman or Gallic ritual, and changeable elements that depend on the customs of a given order. Women who want to devote their lives to religion either as consecrated virgins or temple prostitutes also undergo the rites of passage. These rites are characterised by a familiar pattern: exclusion from the profane world (the ritual of separation) through the change of clothes and donning the veil, integration with God's world through the marriage with Christ (a ring or a crown - in this case, a coif - are the objects used also during the marriage of lay people). According to Gennep, it has to be noted that rituals of exclusion serve here as an ending of the transition period (novitiate), which is characterised by a partial seclusion. A total seclusion takes place after the consecration. So, both the novice and the consecration are marked by a physical isolation from the profane world (the monastery, bars etc.) (p. 113-114).

17 Coptic fragments of the Rule of Pachomius, ed. T. L. Lefort, CSCO 159/Copt. 23, p. 30-36; ed. H. Bacht, "Muséon" 75 (1962), p. 5-18; Greek fragments of the Rule of Pachomius: ed. T. L. Lefort, "Muséon” 37 (1924), p. 1-28; Pachomiana latina, ed. A. Boon, Louvain 1932, p. 169-182.

18 S. Eusebii Hieronymi Stridonensis Presbyteri, Translatio Latina Regulae Sancti Pachomii, MPL 23, p. 65-92; Polish translation: Św. Hieronim ze Strydonu, Reguła św. Pachomiusza, [w:] Pachomiana Latina, ŹM 11, tłum. A. Bober, Kraków 1996, p. 123-172. 
52 The studies regarding monasticism and voluntary poverty...

St. Basil the Great (the so called Asketikon that appeared in 377); ${ }^{19}$ the Rule of St. Augustine - Praeceptum by St. Augustine of Hippo (from 397); ${ }^{20}$ the Rule of the Four Fathers (composed in Lerins between 400 and 410); ${ }^{21}$ the Rule of the Master written before 530; ${ }^{22}$ the Rule of St. Benedict written between 530 and 550. ${ }^{23}$

My aim is to demonstrate that in the early monastic rules there was a gradual emergence and expansion of the initiation pattern of the rites of passage. I will trace the development of this pattern, which had been also present in the earlier religious rituals, from its beginnings to the juridical inclusion of the rites of passage in Christian monastic legislation in the $6^{\text {th }}$ century.

\section{Separation stage}

During the separation stage, which is the initial phase of becoming a monk, an individual is excluded from the current community and his current status is taken away. The candidate who wishes to join the monastic community renounces his previous status and social position. Separation requires a physical isolation from the lay community which involves staying in the house of the monastic

19 S. Basilius Magnus, Caesariensis Archiepiscopus, Regulae fusius tractatae, MPG 31, k. 889-1052; św. Bazyli Wielki, Pisma ascetyczne, t. 2: Reguły dłuższe. Reguły krótsze, ŹM 6, tłum. J. Naumowicz, Kraków 1995.

20 S. Augustinus, Hipponensis Episcopus, Regula ad servos Dei, NBA 7/2, ed. L. Verheijen, Roma 2001, p. 30-48; św. Augustyn, Regula, [in:] św. Augustyn, Pisma monastyczne, ŹM 27, tłum. P. Nehring, Kraków 2002, p. 151-168.

${ }_{21}$ Regula Sanctorum Serapionis, Macarii, Paphnutii et Alterius Macarii, MPL 103, p. 435-442; Polish transl.: Reguła świętych ojców Serapiona, Makarego, Pafnucego i Makarego Drugiego (Reguła Czterech Ojców), [in:] Wczesne reguty monastyczne z Galii, ŹM 3, tłum. K. Bielawski, Kraków $2007^{2}$, p. 41-53.

22 La Règle du Maître, SCh 105-106, éd. A. de Vogüé, Paris 1964; English transl.: The Rule of the Master, Cistercian Publications, trans. L. Eberle, Michigan, p. 105-286.

23 La Règle de Saint Benoît, SCh 181-186, éd. A. de Vogüé, Paris 1971-1972; Polish transl.: Reguła św. Benedykta, [in:] Reguła Mistrza. Reguła św. Benedykta, ŹM 40, tłum. B. Turowicz, Kraków 2006, p. 387-503. 
community and avoiding any contacts with people who are not monks. This initial separation constitutes a trial period for the candidate for monkhood, also called the trial at the gate, during which the candidate is supposed to renounce the right to private property, and according to some rules, he is supposed to don the ritual clothes - the habit. All of this was meant to make the Church community aware of the fact that they dealt with a person who underwent a transition from a layperson to a monk.

\subsection{The initial separation - the trial at the gate}

According to the Rule of St. Pachomius, a candidate that came to a monastery, could not enter the monastery straight away, even if he expressed the willingness to quit the world and to join the coenobitic brothers, and instead such a newcomer was put tested. Once the father of the monastery was informed about the new candidate, the newcomer stayed for a few days at the door of the monastery. ${ }^{24}$ In the meantime, he was supposed to be taught "the Lord's Prayer and the psalms that he is able to learn." ${ }^{25} \mathrm{He}$ then had to show what motivates him to quit the world, and once all exigencies were satisfied and it was discerned that he was a suitable candidate to lead a monastic life, he was taught all disciplines of the monastery (such as what to do, whom to serve, how to behave during the common prayer, in the house or in the refectory). ${ }^{26}$ "Instructed like that and consumed in every good deed, he will be able to be with the brothers." ${ }^{27}$ The newcomer, after having received the instructions, was

\footnotetext{
${ }^{24}$ The Rule of St. Pachomius, Precept 49, http://www.seanmultimedia.com/Pie_ Pachomius_Rule_1.html.

25 The Rule of St. Pachomius, Precept 49, http://www.seanmultimedia.com/Pie_ Pachomius_Rule_1.html.

26 Reguła św. Pachomiusza, Przykazania 49 [The Rule of St. Pachomius, Precept 49], PL 23, k. 73; ŹM 11, p. 137.

${ }^{27}$ The Rule of St.Pachomius, Precept 49, http://www.seanmultimedia.com/Pie_Pachomius_Rule_1.html.
} 
54 The studies regarding monasticism and voluntary poverty...

supposed to learn twenty psalms or two Epistles, or some other part of the Holy Scriptures. And if he could not read, he was supposed to visit a monk appointed to teach him three times a day (at 6, 9 and 12 o'clock). ${ }^{28}$ With time, however, he had to learn how to read, and if he refused, he was forced to learn..$^{29}$ So during the trial period at the gate, the pachomian newcomer became acquainted with the most basic rules of monastic life, in particular prayer. ${ }^{30}$ Also his motivation to lead such a life was verified.

Basil from Caesarean Cappadocia did not speak directly about the trial at the gate, but he did mention the trial period when the candidate should be examined before being admitted. During that time, the candidate was supposed to live in a secluded place so that he did not sin, so that he became free of any temptations and so that he could pray in order to give up his old habits. ${ }^{31}$ Thanks to such a trial taking place in seclusion, the candidate was to forget all that used to be and to give up his whims. ${ }^{32}$ Basil did not specify how long this trial should take, but he was quite specific about its results: the candidate's mind should be free from worries and passions, and the candidate himself should concentrate on becoming like Christ and on longing for Heaven. He also ought be characterised by a repentant heart and humility. ${ }^{33}$

According to Augustine, the trial period also consisted in spiritual recognition of the vocation for monastic life. This recognition was accomplished through the acknowledgement of the necessity to give up the material goods and through the admission that one

\footnotetext{
28 Reguta św. Pachomiusza, Przykazania 139 [The Rule of St. Pachomius, Precept 139], PL 23, k. 92; ŹM 11, p. 154.

${ }_{29}$ The Rule of St. Pachomius, Precept 40, http://www.seanmultimedia.com/Pie_Pachomius_Rule_1.html: "In general, no one at the monastery will stay without being able to read or memorize something from Scripture, at least the New Testament and the Psalter."

30 The Rule of St. Pachomius, Precept 1, PL 23, 67; ŹM 11, p. 128.

31 St. Basil the Great, Greater Rules, 6,1, MPG 31, 925; ŹM 6, p. 73.

32 St. Basil the Great, Greater Rules, 6,1, MPG 31, 925.927; ŹM 6, p. 74.

33 St. Basil the Great, Greater Rules, 8,3, MPG 31, 940.941; ŹM 6, p. 85-86.
} 
is able to live with others in a community of faith. ${ }^{34}$ What should motivate such conduct was the desire to live like the Apostles ${ }^{35}$ in the first Christian community described by Luke in Acts 4:32.35. ${ }^{36}$

According to the Rule of the Four Fathers, a candidate should be put to the test outside the door of a monastery for a week. ${ }^{37}$ During that period, none of the brothers should visit him, "except to drive home to him what a hard and burdensome life he is undertaking." ${ }^{38}$ This way, his perseverance was tested. The candidate that demonstrated his patience could begin a life according to the monastic rule ("uitam fratrum uel reulam tenere possint") and he was instructed by the superior how to observe the rules of co-existence with the brothers in the monastery. ${ }^{39}$

In the Rule of the Master, there is no mention of the trial at the door of the monastery. The anonymous writer of this particular monastic regulation was more interested in finding out the reasons why the candidate wished to join the monastery and in showing him the hardships associated with the monastic life. So the abbot was supposed to test the candidate by examining his motivation..$^{40}$

34 Augustine of Hippo, Praeceptum, 1,2, NBA 7/2, 30; ŹM 27, p. 155.

35 (Alipius?; Augustine of Hippo?), Ordo monasterii (aka Regula Secunda), 4, MPL 32, p. 1451; ŹM 27, p. 152; it is the work within a range of Augustine's thought; there are a lot of doubts as to whether bishop Hippo Regius is its author. For more discussion regarding the authorship of Ordo monasterii see: P. Nehring, Wstęp, ŹM 27, p. 62-64.

36 Augustine of Hippo, Praeceptum, 1,2, NBA 7/2, 30; ŹM 27, p. 155; cf. Possidio Calamensi Episcopo, Vita Sancti Aurelii Augustini, 5,1, MPL 32, 37; Polish translation: Possydiusz z Kalamy, Żywot św. Augustyna, 5,1, ŹM 26, tłum. P. Nehring, Kraków 2002, p. 59.

37 The Rule of Four Fathers, 2,25, PL 103, 437; Polish transl.: ŹM 3, p. 45.

38 Quoted in Terrence G. Kardong, Pillars of community. Four rules of pre-Benedictine monastic life, Collegeville 2010.

39 The Rule of Four Fathers, 2,27, PL 103, 438; ŹM 3, p. 45.

40 The Rule of the Master, 87,1-2: "When a new member enters the monastery, whether he has already turned to God or is still of the world, and asks the favour of being accepted into the monastery, let the abbot at first tell him that he may not be able to keep the prescriptions of the Rule," The Rule of the Master, Cistercian Publications, trans. L. Eberle, Michigan 253. 
The studies regarding monasticism and voluntary poverty...

But "if the candidate says he can be obedient in all things, then let this Rule of the monastery be read to him."41

The Rule of St. Benedict demanded that the candidate was put to a test, which should not be easy, so that the sincerity of his vocation could be examined. ${ }^{42}$ This trial should last for four to five days, during which the candidate should persevere in his request and patiently bear the harsh treatment. ${ }^{43}$ After the successful trial, the candidate was allowed to begin the monastic life. For the next few days he lived in the guest quarters ${ }^{44}$ and only then was he allowed to live in the apartment of novices thus beginning the novitiate. ${ }^{45}$

So, the preliminary trial period, also called the trial at the door or the trial at the gate, could last for a few days (the Rule of St. Pachomius), for 4/5 days (the Rule of St. Benedict) up to a week (the Rule of the Four Fathers). Other rules gave only a general outline regarding the probationary period in which the motivation of the candidate was to be examined. During the trial period, the candidate's patience, humility and readiness to bear various "instructive/pedagogical humiliations" (such as, for example, the superior discouraging a candidate from living in the monastery) were examined. Also the candidate's past was put under scrutiny and he was instructed about the life in the monastic community. According to the first monastic rules (Parchomius', Basil's, Augustine's and Four Fathers'), on successful completion of the trial period, the candidate became a monk. According to the later rules (the Rule of the Master and the Rule of St. Benedict), after

\footnotetext{
$41 \quad$ The Rule of the Master (87,3: "cum uero ille dixerit posse se ad omnia obaudire, tunc haec monasterii regula ei legatur”: SCh 106, 356;), 253.

42 The Rule of St. Benedict, 58: "Let easy admission not be given to one who newly cometh to change his life; but, as the Apostle saith, 'Try the spirits, whether they be of God' (1 Jn 4:1)." http://www.ccel.org/ccel/benedict/rule2/files/rule2.html.

43 The Rule of St. Benedict, 58,3, SCh 182, 626; ŹM 40, p. 481.

44 The Rule of St. Benedict, 58,4, SCh 182, 626; ŹM 40, p. 481.

45 The Rule of St. Benedict, 58,5, SCh 182, 626; ŹM 40, p. 481.
} 
the first trial there was another trial awaiting the candidate, and only after this second trial, the candidate was admitted to monastic profession.

\subsection{Renunciation of private property}

In the first (instance of) Christian coenobitic legislation, that is in the Rule of St. Pachomius, the candidate who wanted to join the community of monks, after the preliminary tests and instructions, was supposed to provide a detailed account of himself: "to make sure that they haven't committed a crime, and troubled by fear, had fled without delay to the monastery; or that he is a slave of someone. This will allow us to discern if he will be able to quit his relatives and to undervalue material richness." ${ }^{46}$ So, the father of the monastery examining the motivation of the candidate had to hear and receive the declaration that the candidate disowned his parents and that he renounced his possessions. Only after receiving such a declaration, the father of the monastery decided provisionally whether the candidate was ready for such a life and instructed him about the disciplines of the monastery. ${ }^{47}$

According to St. Basil the Great, before entering the monastery, the candidate who went to a secluded place had to renounce himself and to take up the Jesus' Cross. ${ }^{48}$ Explaining these exigencies in the Greater Rules, Basil claims that renouncing oneself requires forgetting all that used to be and giving up one's whims. To carry Christ's Cross requires readiness to die for Christ, to kill all that is earthly in our limbs, and to face any potential dangers connected with professing the name of Jesus Christ, as well as renouncing all

46 The Rule of St. Pachomius, Percept 49, http://www.seanmultimedia.com/Pie_Pachomius_Rule_1.html. Reguła św. Pachomiusza, Percept 49: "ne forte mali quidpiam fecerit, et turbatus ad horam timore discesserit, aut sub aliqua potestate sit et utru possit renuntiare parentibus suis, et propriam contemnare facultatem.” MPL 23, 73; ŹM 11, p. 137.

47 The Rule of St. Pachomius, [Percept 49], MPL 23, 73; ŹM 11, p. 137.

48 Basil the Great, Greater Rules, 6,1, MPG 31, 925; ŹM 6, p. 73-74. 
The studies regarding monasticism and voluntary poverty...

attachments to earthly life. ${ }^{49}$ The candidate who thus acts, leaves "the world of indifference," 50 the community that interferes with carrying the Cross and following the Christ, ${ }^{51}$ the havoc and affairs $\mathrm{TBC},{ }^{52}$ the world in which he loses the ability to enjoy God and to be well pleased in Him so that he can take great delight in Lord and feel the sweetness of his words ${ }^{53}$ the world that is used to disregard God's decrees and fails to remember them. ${ }^{54}$ Leaving the earthly world behind and isolating oneself from it in the monastery constitutes the beginning of the coenobitic life which aim is to win God's approval..$^{55}$

According to Augustine from Hippo, the one who wishes to become a monk, had to renounce all material goods and could not keep anything for himself. ${ }^{56}$ Augustine set as an example an ideal community of apostles from Jerusalem presented by Luke in Acts 4,32, and especially their unanimity ${ }^{57}$ and sharing all material goods in common..$^{58}$ The above regulations had to be observed by those who decided to live in the monastery. ${ }^{59}$

According to the Rule of the Four Fathers, the renunciation of private property was a paramount requirement during the initial phases of monastic initiation..$^{60}$ Once a candidate renounced his wealth, he was instructed by the superior about the rules of obedience and the renunciation of one's will. ${ }^{61}$ The candidate could

\footnotetext{
Basil the Great, Greater Rules, 6,1, MPG 31, 925; ŹM 6, p. 74.

Basil the Great, Greater Rules, 6,1, MPG 31, 925; ŹM 6, p. 74

Basil the Great, Greater Rules, 6,1, MPG 31, 925; ŹM 6, p. 74.

Basil the Great, Greater Rules, 6,2, MPG 31, 927; ŹM 6, p. 74.

Basil the Great, Greater Rules, 6,2, MPG 31, 927; ŹM 6, p. 74.

Basil the Great, Greater Rules, 6,2, MPG 31, 927; ŹM 6, p. 75.

Basil the Great, Greater Rules, 7,2, MPG 31, 929; ŹM 6, p. 75.

[Alipius?; Augustine of Hippo], Ordo monasterii, 4, MPL 32, 1451; ŹM 27, p. 152.

Augustine of Hippo, Praeceptum, 1,2, NBA 7/2, 30; ŹM 27, p. 155.

Augustine of Hippo, Praeceptum, 1,3-8, NBA 7/2, 30.32; ŹM 27, p. 155-157.

9 Augustyn z Hippony [Augustine of Hippo], Praeceptum, 1,1, NBA 7/2, 30; ŹM 27,

The Rule of Four Fathers, 2,29-31, PL 103, 438; ŹM 3, p. 46.

${ }_{61}$ The Rule of Four Fathers, 2,32-33, PL 103, 438; ŹM 3, p. 46.
} p. 155. 
bestow some portion of his wealth on the monastery as an offering and could also take one slave with him, whom he should treat henceforth as a brother. ${ }^{62}$

The renunciation of private property was also a fundamental requirement for beginning monastic life according to the anonymous author of the Rule of the Master.$^{63}$ A candidate was supposed to sell his goods and to bring the money to the abbot who gave it to the poor on the candidate's behalf. The sale of all possessions and the distribution of property among the poor were absolutely necessary. Only when the candidate renounced earthly goods was he admitted to the monastery. ${ }^{64}$ Moreover, the candidate could not take the precaution of reserving any possessions to himself in case he wanted to go back to the world. ${ }^{65}$ Only then he took vows in the presence of the abbot to renounce everything. ${ }^{66}$ The author of the Rule of the Master was less demanding, however, towards the candidates of gentry background. After the initial pledge by a nobleman-candidate to be obedient to the abbot in the scope of the duties inherent in the Rule, ${ }^{67}$ the reaction of the candidate's parents to the candidate's decision to join the monastery was examined. ${ }^{68}$ If the parents who had authority over their son agreed that he entered the monastery, ${ }^{69}$ they could choose between three options. First, they could let their son sell the part of their property that was his due. ${ }^{70}$ Second, they could divide his portion into three equal parts: one was to be distributed among the poor by the abbot on the candidate's behalf; the second part could be left to

62 The Rule of Four Fathers, 2,32-33, PL 103, 438; ŹM 3, p. 46.

63 The Rule of the Master, 87,5-18, trans. L. Eberle, p. 253-254.

64 The Rule of the Master, 87,41-48, trans. L. Eberle, p. 255.

65 The Rule of the Master, 87,19-24, trans. L. Eberle, p. 254.

66 The Rule of the Master, 87,26.28.31, trans. L. Eberle, p. 254.

67 The Rule of the Master, 91,1, trans. L. Eberle, p. 267.

68 The Rule of the Master, 91,2-7, trans. L. Eberle, p. 267.

69 The Rule of the Master, 91,45, trans. L. Eberle, p. 270.

70 The Rule of the Master, 91,43-47, trans. L. Eberle, p. 270. 
The studies regarding monasticism and voluntary poverty...

the candidate's family in the form of a bequest; and the third one could be given to the monastery as a dowry. ${ }^{71}$ Thirdly, if the parents of the son joining the abbey did not want to divide their son's property and they did not give him any of his material goods, they had to formally disinherit him. ${ }^{72}$

In the Rule of St. Benedict there is a clear recommendation that a candidate should dispose of his property to the poor or to bestow it on the monastery by a formal donation..$^{73}$ According to the Rule of St. Benedict the renunciation of private property took place not at the beginning of the monastic life but after the year of trial in the monastery, ${ }^{74}$ when the novice brother was making the promise of stability, the conversion of morals and obedience. ${ }^{75}$ After making such a promise and renouncing private property the monk was under the Abbot's authority because "he should know that from that day onward he will no longer have power even over his own body." ${ }^{\prime 6}$ The renunciation of property was symbolised by the change of clothes. The monk was divested of the garments with which he was clothed and was vested in the garb of the monastery. ${ }^{77}$ When the boy of tender age and of noble birth joined the monastery, the family was obliged to submit a document in which they bound themselves under oath "that they will never give him anything themselves nor through any other person, nor in any way whatever, nor leave a chance for his owning anything." ${ }^{78}$ They were also obliged to make a donation to the monastery understood as reimbursement

71 The Rule of the Master, 91,52, trans. L. Eberle, p. 270.

72 The Rule of the Master, 91,55-69, trans. L. Eberle, p. 270-271.

73 The Rule of St. Benedict, 58,24, SCh 182, 630.632; ŹM 40, p. 483.

74 The Rule of St. Benedict, 58,9.12-13, SCh 182, 628; ŹM 40, p. 481-482.

75 The Rule of St. Benedict, 58,14-24: SCh 182, 628.630.632; ŹM 40, p. 482-483.

76 The Rule of St. Benedict, 58, http://www.ccel.org/ccel/benedict/rule2/files/ rule2.html.

77 The Rule of St. Benedict, 58,26, SCh 182, 632; ŹM 40, p. 483.

78 The Rule of St. Benedict, 58, http://www.ccel.org/ccel/benedict/rule2/files/ rule2.html. 
of costs incurred, ${ }^{79}$ which was also supposed to be legally certified. ${ }^{80}$ A similar declaration was supposed to be made by the poor who offered their underage son to the monastery. ${ }^{81}$

The renunciation of private property was the most important stage of the separation phase during the initiation into monastic life. The rite of external/outer renunciation was to be accompanied by inner freedom which was manifested by the lack of attachment to material goods. According to most authors of the analysed rules, the renunciation occurred at the beginning of the monastic life. Only in the Rule of St. Benedict, did the renunciation of private property took place after the year of trial. The monks were to renounce not only private property, understood as an individual management of earthly goods, but also their free will, amour propre, and the relationship with their parents. According to the authors of the rules, the motives for making this sacrifice were various: complete forgetting of what used to be and giving up of one's whims (the Rule of St. Basil); a community of minds and hearts, which was to make the monk at God's disposal (the Rule of St. Augustine); a preventative measure that was to guarantee that the monk did not leave the monastery (the Rule of the Master); a renunciation of the world and free fill which was an expression of the authenticity of the vocation itself (the Rule of St. Pachomius, the Rule of the Four Fathers, the Rule of St. Benedict). The renunciation of property involved the sale of goods and distribution of money thus earned among the poor, or a donation to the monastery. Once the monk

79 The Rule of St. Benedict, 59,4, SCh 182, 634; ŹM 40, p. 484.

80 The Rule of St. Benedict, 59,5, SCh 182, 634; ŹM 40, p. 484.

81 The Rule of St. Benedict, 59,7-8: "Similiter autem et pauperiores faciant. Qui uero ex toto nihil habent, simpliciter petitionem faciant et cum oblatione offerant filium suum coram testibus." SCh 182, 634; English translation: "Let those who are poor act in like manner. But as to those who have nothing at all, let them simply make the declaration, and with the oblation offer their son in the presence of witnesses.” The Rule of St. Benedict, 59, http:// www.ccel.org/ccel/benedict/rule2/files/rule2.html. 
The studies regarding monasticism and voluntary poverty...

made a promise to renounce private property, he had to keep that promise for the rest of his life.

\subsection{The clothing ceremony - the ritual of receiving the monastic garb (the habit)}

According to the Rule of St. Pachomius, upon the renunciation of property and initial instructions in the monastic disciplines, the candidate was included in the brethren. ${ }^{82}$ The clothing ceremony was a symbol of this acceptance. The clothing ceremony itself involved divesting the candidate's own clothes and vesting the habit of the monks. Thus clothed, the candidate was trusted to the doorman who, during the time of prayer, took him to the presence of all brothers and made him sit in his assigned place. ${ }^{83}$ As for types of attire, the pachomian monk could own only such garments as his superior gave him, that is "two robes, plus another worn out by the use, a garment big enough so as to roll the collar and the back, and a skin of goat, that is buttoned on one side, shoes, two cowls, and a cane." 84 Vincent Desprez, OSB, commenting on the pachomian rules of clothing, noted that the main piece of clothing was a lebiton or colobion - a sleeveless tunic. The monk had two such tunics in his cell: a newer one for a morning prayer and a wornout one which served as an outer-garment. There was also a linen mantle - a kind of a cape covering neck and shoulders at night and during the prayer; a goat skin, called melota, sandals, two cowls

\footnotetext{
82 Rule of St. Pachomius, Percept 49: “ut instructus, atque perfectum in omni opere bono, fratribus copuletur." PL 23, k. 73; English translation: "Instructed like that and consumed in every good deed, he will be able to be with the brothers." http://www.seanmultimedia.com/Pie_Pachomius_Rule_1.html.

${ }^{83}$ Rule of St. Pachomius, Percept 49, http://www.seanmultimedia.com/Pie_ Pachomius_Rule_1.html.

${ }^{84}$ Rule of St. Pachomius, Percept 49, http://www.seanmultimedia.com/Pie_ Pachomius_Rule_1.html.
} 
(that is hoods), a bell of linen and a cane. This dress was similar to that of anchorites. ${ }^{85}$

St. Basil the Great did not mention a special clothing ceremony in his Rule, but he did point out that a monk's attire should not be elegant or elaborate; ${ }^{86}$ rather they should have just one garment serving several needs in order to preserve the principle of poverty ${ }^{87}$ and modesty. ${ }^{88}$ The garment should also be adequate and it should be different for monks and nuns. ${ }^{89}$ Józef Naumowicz commenting on the aforementioned dress code of Basilian monks, notes that "it is not entirely clear whether Basil assigned special clothing to 'Christians' from ascetic communities, but some fragments of Chapter 22 of the Greater Rules seem to indicate that he did."90

Similarly, Augustine in his Rules did not mention the clothing ceremony or a special attire for a monk. He only stated that monk's clothing should be modest and a monk himself should not seek to please by their clothes but by a good life. ${ }^{91}$ Monks wore normal clothing, like this of ordinary people. So, the Augustinian monks wore the same clothes in which they came to the monastery. All clothes, however, were kept in a single wardrobe and were cleaned

85 V. Desprez, Cenobityzm pachomiański, ŹM 11: Pachomiana latina, Kraków 1996, p. 40-41; sandals as a part of pachomian monk's dress are mentioned by St. Jerome in his Preface to the rule of St. Pachomius (Przedmowa 4[4] do Reguty św. Pachomiusza, PL 23, 67; ŹM 11, p. 125.)

86 Basil the Great, Greater Rules, 22,1, PG 31, 977; ŹM 6, p. 117.

87 Basil the Great, Greater Rules, 22,2, PG 31, 977.979; ŹM 6, p. 118.

88 Basil the Great, Greater Rules, 22,3, PG 31, 979; ŹM 6, p. 119.

89 Basil the Great, Lesser Rules, 210, PG 31, 1221.1224; ŹM 6, p. 360-361. As J. Naumowicz, the translator, noted in a footnote: "a mention of a different dress code for men and women can allude to practices in the Eustachian movement, which paid an enormous attention to donning a special dress that was to be the same for both sexes." [own translation] To read more on a possibility of Basil the Great's monastic regulations being a reaction to Eustachian asceticism, see: D. Kasprzak, Eustacjański kontekst doktryny o ubóstwie monastycznym $w$ pismach ascetycznych Bazylego Wielkiego (The ascetic writings of Basil the Great in the context of the Eustachius' of Sebaste monastic poverty doctrine), "Vox Patrum" 30 (2010) vol. 55, p. 257-273.

$90 \quad$ Basil the Great, Greater Rules, 22,3, PG 31, 979; ŹM 6, p. 119, footnote 258.

91 Augustine of Hippo, Praeceptum, 4,1, NBA 7/2, 36; ŹM 27, p. 159. 
64 The studies regarding monasticism and voluntary poverty...

by the people appointed by the superior and were distributed according to individual needs. ${ }^{92}$

Whereas in the Lerins Rule of Four Fathers there is no mention of the clothing ceremony or the type of clothes the monks should wear, the anonymous author of the Rule of the Master instructs about the monastic habit in Chapter 90. According to this author, the lay candidate should neither change his clothes nor receive the tonsure for a year since entering the monastery. Receiving the habit as a symbol of devotion to God was possible only once the candidate passed the humility and obedience trial, because he should not be "too readily believed" 93 and the superiors should not "let him be so quickly clothed with the religious habit." ${ }^{94}$ Leaving the world and entering the monastic life was supposed to be authenticated by going through difficult tests of willpower: "To test him let difficulties be made, and to ascertain his obedience let him be told in advance about things contrary and repugnant to his will." ${ }^{95}$ That is why daily fasting was announced to him ${ }^{96}$ and he was asked to renounce his will, ${ }^{97}$ to submit to the authority of the superior - "we serve in the school of the monastery under the abbot's command through testing and thwarting of the will." 98 to renounce his parents and his will. ${ }^{99}$ The candidate went through these trials wearing his usual clothes. ${ }^{100}$

Upon successful completion of the trials, the candidate was tonsured by the abbot and he was clothed with the monastic habit. ${ }^{101}$

\footnotetext{
Augustine of Hippo, Praeceptum, 5,1, NBA 7/2, 40; ŹM 27, p. 162-163.

The Rule of the Master, 90,1, trans. L. Eberle, p. 260.

The Rule of the Master, 90,68, trans. L. Eberle, p. 264.

The Rule of the Master, 90,3, trans. L. Eberle, p. 260.

The Rule of the Master, 90,4, trans. L. Eberle, p. 260.

The Rule of the Master, 90,5-28, trans. L. Eberle, p. 260-261.

The Rule of the Master, 90,29, trans. L. Eberle, p. 262.

The Rule of the Master, 90,63-65, trans. L. Eberle, p. 264.

100 The Rule of the Master, 90,78: "in tuis adhuc uestibus." SCh 106, 392; English translation: "still in your own clothes." Trans. L. Eberle, p. 265.

101 The Rule of the Master, 90,79-81, trans. L. Eberle, p. 265.
} 
The monastic garb was described as "the habit of their holy intention,"102 "the holy garments,"103 "the sacred habit,"104 or "the garb of Christ," 105 so it was not until the candidate vested the habit, could he pray and eat with the abbot. ${ }^{106}$ His former clothes ("the secular clothes," "his own garments," the symbol of conforming to the world, the sign of return to the devil his counsellor), after the year of probation, were put away and kept in a wardrobe as a symbol of the life one abandoned in converting to the monastic life. ${ }^{107}$

The Rule of St. Benedict reiterated general principles of clothing with the habit, provided in the Rule of the Master. The habit represented an outward symbol of the monastic vows and this is why it was conferred after the vows were taken. After a year of trial, ${ }^{108}$ the candidate promised in oratory, in the presence of all, the conversion of morals and obedience ${ }^{109}$ and renounced all his possessions. ${ }^{110}$ Only after the aforementioned promise, was he divested of the garments with which he was clothed and vested in the garb of the monastery. ${ }^{111}$ As in the Rule of the Master so in the Rule of St. Benedict, there was a recommendation that the clothes of which the candidate was divested should be stored away and kept in a wardrobe. ${ }^{112}$ Should the monk ever leave the monastery,

102 The Rule of the Master, 90,82: “sancti propositi habitum." SCh 106, 394; trans. L. Eberle, p. 265.

103 The Rule of the Master, 90,85: “sanctis uestibus.” SCh 106, 394; trans. L. Eberle, p. 266.

104 The Rule of the Master, 90,85: "habitu sacro." SCh 106, 394; trans. L. Eberle, p. 266.

105 Cf. The Rule of the Master, 90,84-85.86: "reddat Christo quo suum est, id est, exutus sanctis uestibus; [...] et non Christi praedatus habitus polluatur in saeculo a fugaci." SCh 106, 394; trans. L. Eberle, p. 266.

106 The Rule of the Master, 90,82, trans. L. Eberle, p. 265.

107 The Rule of the Master, 90,83-87, trans. L. Eberle, p. 266.

108 The Rule of St. Benedict, 58,1-13, SCh 182, 626.628; ŹM 40, p. 481-482.

109 The Rule of St. Benedict, 58,17: "Suscipiendus autem in oratorio coram omnibus promittat de stabilitate sua et conuersatione morum suorum et oboedientia." SCh 182, 630; ŹM 40, p. 482.

110 The Rule of St. Benedict, 58,24-25, SCh 182, 630.632; ŹM 40, p. 483.

111 The Rule of St. Benedict, 58,24-25, SCh 182, 630.632; ŹM 40, p. 483.

112 The Rule of St. Benedict, 58,27, SCh 182, 632; ŹM 40, p. 483. 
The studies regarding monasticism and voluntary poverty...

he had to hand back his monastic habit, ${ }^{113}$ and more than likely had his clothes returned to him. He could not, however, be given back the donation that he made at the time of taking the vows. ${ }^{114}$

In half of the analysed monastic rules, the habit was an outward symbol of becoming a monk and joining the monastic community (the Rules of: St. Pachomius, the Master and St. Benedict). The rest of documents either just mentioned that a monk's apparel should be threadbare and modest, but they did not necessarily treat it as the monastic habit (the Rules of: St. Basil and St. Augustine), or they ignored a monk's clothing altogether (the Rule of Four Fathers). Depending on the monastic tradition, the clothing ceremony took place either after a short trial period and initial instructions (the Rule of St. Pachomius) or after a year of testing one's obedience, as a symbol of consecration performed publicly either in front of or in the oratory (the Rule of the Master, the Rule of St. Benedict). In contrast, neither St. Basil nor St. Augustine from Hippo mentioned the clothing ceremony in their principles of the monastic life. They only gave spiritual guidance concerning the modesty of monastic clothes. The first Augustinian monks wore clothes that they were given by those in charge of clothing. There are also some doubts as to whether Basil recommended a special monastic attire or whether he just favoured ordinary, modest and threadbare clothes.

\section{The transition phase}

In this phase of the monastic life, a candidate was treated as a novice monk - someone who stopped being a layperson but did not yet become a fully-fledged monk. The trial period - depending on the rule - lasted for a few days, or months, even up to a year. According

\footnotetext{
113 The Rule of St. Benedict, 58,28, SCh 182, 632; ŹM 40, p. 483.

114 The Rule of St. Benedict, 58,29, SCh 182, 632; ŹM 40, p. 483.
} 
to the first coenobitic rules, there was just one trial (instead of two). At the heart of the transition phase, there were a number of actions taken by the monks responsible for the admission and monastic formation of candidates admitted so that the authenticity of their vocation to monastic life could be verified.

The primitive coenobitic legislation, that is the Rule of St.Pachomius, says that on successful completion of the trial at the door/ gate of the monastery, so usually after a few days, a candidate was no longer subjected to formation trials, but formally became a monk and was admitted to the monastic community. ${ }^{115}$ Similar legislation was put forward in the Rule of the Four Fathers, which did not include any additional probation period, apart from a weekly trial period, for the candidate for monkhood. ${ }^{116}$ St Basil the Great ${ }^{117}$ wrote about the probationary period but it is difficult to determine unequivocally whether he meant something else than the aforementioned preliminary trial. ${ }^{118}$ In the writings of St. Augustine of Hippo, there is no mention of an extra probationary period, different from a preliminary trial. ${ }^{119}$ So, these early monastic rules after a single preliminary trialallowed the candidate to take radical vows of monastic life, which basically meant that the candidate committed himself to remain in the monastic life forever. Monastic legislation changed at the end of the antiquity and from the $6^{\text {th }}$ century onwards, probably due to the feudalisation and Germanisation of Western Church (Christianity), these early ideas were abandoned. Beginning with the Rule of the Master and the Rule of St. Benedict

115 Rule of St. Pachomius, Percept 49, http://www.seanmultimedia.com/Pie_Pachomius_Rule_1.html.

116 The Rule of Four Fathers, 2,25, PL 103, 437-438; ŹM 3, p. 45.

117 Basil the Great, Greater Rule, 6,1-2, PG 31, 925.927; ŹM 6, p. 73-75.

118 G. M. Colombás, Il monachesimo delle origini, Milano 1990, p. 209, talking about the Basilian coenobitism, maintains that the candidate for the monastic life in the monastery was to go through the trial period, but its length was nowhere specified. The ascetic rule of Basil also did not specify whether candidates should observe any rules, apart from keeping silent and learning the fragments of Bible by heart.

119 Augustine of Hippo, Praeceptum, 1,2, NBA 7/2, 30; ŹM 27, p. 155. 
The studies regarding monasticism and voluntary poverty...

until the $7^{\text {th }} / 8^{\text {th }}$, the candidate was considered to be a free man who could leave the monastery at any point of the transition phase. ${ }^{120}$

The Rule of the Master provided for two different trial periods: one for conversi $i^{121}$ and one for lay postulants. ${ }^{122}$ A conversus ${ }^{123}$ was to be discouraged by the abbot to begin such a form of life, ${ }^{124}$ and when he still insisted on beginning the monastic life, the rule was read to him ${ }^{125}$ and he had to renounce all possessions (either "by disposing of his possessions as alms or as a gift to the monastery, or by a document of guaranty under penalty, or if his unknown, by a sworn promise"). ${ }^{126}$ Then he was admitted for two "so that such a one may make trial of the monastery's way of life and himself be tested by the monastery."127 The candidate was to stay in the pilgrim quarters and he was to be taken care of by the brothers who watched over pilgrims. ${ }^{128}$ He was to devote that year to pondering whether entering monastic life was the right decision. After twelve months, when the candidate chose the monastic way of life, he

120 V. Hermans, De novitiatu in Ordine benedictino-cisterciensi et in iure communio usque ad annum 1335, “Annalecta Sacri Ordinis Cisterciensis” 3 (1947), p. 1-110, in particular 70-83.

121 The Rule of the Master, 88-89, trans. L. Eberle, p. 257-260.

122 The Rule of the Master, 90, trans. L. Eberle, p. 260-267.

123 The term conversus was used in the early Middle Ages (from the 7th to 12th century) to describe: 1 . monks (monachus conversus) who entered the monastery in their mature years and were illiterate (although some of them did become priests later) or uneducated; 2. monks who belonged to familia of a given monastery (famulus conversus) and led a pious life but did not take upon themselves all duties of the monastic life. In both cases, the term conversus was used, which in fact was an adjective, as it described the monk as either monachus conversus or famulus conversus. For more information on the early (from the $5^{\text {th }}$ to $7^{\text {th }}$ century) and late (after the $12^{\text {th }}$ century) use of the term conversus, see: D. Kasprzak, Duszpasterze V wieku. Studium porównawcze myśli pasterskiej św. Piotra Chryzologa i Salwiana z Marsylii, Kraków 2008, p. 74-76, especially footnotes number: 160 and 169.

124 The Rule of the Master, 87, trans. L. Eberle, p. 253-257.

125 This percept applies to both conversi and lay postulants cf. The Rule of the Master, 87,4, trans. L. Eberle, p. 253.

126 The Rule of the Master, 88,2, trans. L. Eberle, p. 257.

127 The Rule of the Master, 88,5: "ut et mores monasterii probet et a monastreio ipse probetur.” SCh 106, 368; trans. L. Eberle, p. 257.

128 The Rule of the Master, 88,3-4.6-10, trans. L. Eberle, p. 257. 
provisionally promised the abbot obedience in everything, and then he made this promise again, publicly, in the oratory during a monastic profession ceremony. ${ }^{129}$ But if he did not want to make profession, he could leave the monastery either in harmony in which case he offered and received the sign of peace and was given a lamp and some provisions for the road, ${ }^{130}$ or in conflict/in disagreement "If he wishes it, let him depart as a guest, and let the devil reclaim this citizen of his, whom Christ unwillingly received as a guest."131

Similarly, a lay petitioner who came to the monastery was to be discouraged by the abbot "only verbally, not actually" 132 and "to test him, let difficulties be made, to ascertain his obedience." ${ }^{\prime 33}$ Daily fasting was to be announced to him ${ }^{134}$ and through the abovementioned trials he was to learn how to give up his own will and how to be obedient to the abbot. ${ }^{135}$ The probationary period for a layperson was to last a year, after which, the abbot tonsured and clothed the candidate with a habit in the oratory in the presence of gathered monks. ${ }^{136}$

A monastery that followed the Rule of the Master could also admit priests, but there were no particular guidelines regarding the duration of their initial formation. The anonymous Master recommended only that priests who decided to take advantage of monastic food and clothes on daily basis should work with other brothers. ${ }^{137}$ If they refused, they should be admonished, and if that did not help, the things belonging to the monastery should be taken away from them, "provided there is no serious injury," and they

\footnotetext{
129 The Rule of the Master, 89,1-25, trans. L. Eberle, p. 258-259.

130 The Rule of the Master, 88,11-13, trans. L. Eberle, p. 257-258.

131 The Rule of the Master, 88,14, trans. L. Eberle, p. 258.

132 The Rule of the Master, 90,2, trans. L. Eberle, p. 260.

133 The Rule of the Master, 90,3, trans. L. Eberle, p. 260.

134 The Rule of the Master, 90,4, trans. L. Eberle, p. 260.

135 The Rule of the Master, 90,5-66, trans. L. Eberle, p. 260-264.

136 The Rule of the Master, 90,79-82, trans. L. Eberle, p. 265.

137 The Rule of the Master, 83,10-16, trans. L. Eberle, p. 249.
} 
The studies regarding monasticism and voluntary poverty...

should be dismissed from the monastery. ${ }^{138}$ Whereas priests were admitted to the monastery on the condition that they were obedient and worked for the community, sons of nobility, after a preliminary trial of obedience, were admitted on the condition that they renounced their possessions. ${ }^{139}$

The Rule of St. Benedict contained different trials for conversi and lay petitioners ${ }^{140}$ and different for noblemen ${ }^{141}$ and priests. ${ }^{142}$ Conversi and laymen, after a preliminary trial of four or five days, were admitted to the monastery. After a few more days in guest quarters, ${ }^{143}$ they were supposed to move to the apartment of novices where they "mediate[d], eat [ate] and sleep [slept]."144 The novices were to be supervised by a senior monk ("a senior"), "qualified to win souls," 145 who was to check their eagerness for a common prayer and obedience and their humility/ability to bear humiliation. ${ }^{146} \mathrm{He}$ was also supposed to present the monastic life as a hard and rugged way to God. ${ }^{147}$ After two months, if the candidate remained steadfast, the whole Rule was read to him. ${ }^{148} \mathrm{He}$ was then taken back to the apartment of novices for another six months, and after the lapse of these six months, the rule was read over to him. ${ }^{149}$ Next, he was tested for another four months, and if he remained firm, the rule was read to him again. ${ }^{150}$ So, when the conversus or

138 The Rule of the Master, 83,17-22, trans. L. Eberle, p. 249-250.

139 The Rule of the Master, 91, trans. L. Eberle, p. 267-271.

140 The Rule of St. Benedict, 58, SCh 182, 626-632; ŹM 40, p. 481-483.

141 The Rule of St. Benedict, 59, SCh 182, 632.634; ŹM 40, p. 484.

142 The Rule of St. Benedict, 60, SCh 182, 634.636; ŹM 40, p. 485.

143 The Rule of St. Benedict, 58,3-4, SCh 182, 626; ŹM 40, p. 481.

144 The Rule of St. Benedict, 58, http://www.ccel.org/ccel/benedict/rule2/files/ rule2.html.

145 The Rule of St. Benedict, 58, http://www.ccel.org/ccel/benedict/rule2/files/ rule2.html.

146 The Rule of St. Benedict, 58,7, SCh 182, 626.628; ŹM 40, p. 481.

147 The Rule of St. Benedict, 58, http://www.ccel.org/ccel/benedict/rule2/files/ rule2.html.

148 The Rule of St. Benedict, 58,9, SCh 182, 628; ŹM 40, p. 481.

149 The Rule of St. Benedict, 58,12, SCh 182, 628; ŹM 40, p. 482.

150 The Rule of St. Benedict, 58,13, SCh 182, 628; ŹM 40, p. 482. 
layman accepted the law of the Rule, after a year of trial they were allowed to make monastic profession. ${ }^{151}$

As for the underage candidates of a noble origin offered to the monastery, the Rule of St. Benedict did not comprise any additional guidelines regarding the probationary period, but there were legal obligations for the parents not to deliver their sons anything to the monastery. The parents could, however, bestow a dowry on the monastery as a kind of reimbursement ${ }^{152}$ - "to make an offering to the monastery as an alms." ${ }^{153}$ The transition took therefore the same form as in the case of conversi and laymen. As for the priests who wanted to join the Benedictine monastery, they were tested in patience and they had to promise to keep the discipline of the Rule. ${ }^{154}$ There was no mention, however, of the length of their trial, which was undoubtedly adjusted to a given candidate. ${ }^{155}$

The early coenobitic rules (St. Pachomius', Basil's, Augustine's, Four Fathers') suggested just one preliminary trial for everyone. The aim of this trial was to verify the authenticity of the vocation of candidates coming to the monastery. It was not until the first half of the $6^{\text {th }}$ century and the Rule of the Master and the Rule of St. Benedict that each transition phase was made into a separate trial for various candidates from different walks of life (priests, noblemen, laymen and conversi). According to the Rule of the Master, the trial period was to last two months for a conversus and a year for a layman. For priests and noblemen the exact duration of the trial period was not specified. The Rule of St. Benedict proposed

151 The Rule of St. Benedict, 58,14-16, SCh 182, 628; ŹM 40, p. 482.

152 The Rule of St. Benedict, 59, 1-6, SCh 182, 632.634; ŹM 40, p. 484.

153 The Rule of St. Benedict, 58, http://www.ccel.org/ccel/benedict/rule2/files/rule2. html. Reguła św. Benedykta, 59,4: "aliquid offerre uolunt in elemosinam monasterio pro mercede sua.” SCh 182, 635; ŹM 40, p. 484.

154 The Rule of St. Benedict, 60,1-2, SCh 182, 634; ŹM 40, p. 485.

155 Cf. J. Leclercq, Pédagogie et formation spirituelle du VIe au XIIe siècle, [in:] La scuola nell'Occidente latino dell'alto medioevo, Settimane di studio del Centro italiano di studi sull'alto Medioevo 19, Spoleto 1972, p. 255-290. 
The studies regarding monasticism and voluntary poverty...

the preliminarily trial of a few days followed by a twelve month trial. During this long transition phase, divided into stages of two, four and six months, the candidate's prayer, obedience and humility were examined. Once he declared the obedience to the law of the rule, he was admitted to make monastic profession.

The transition phase in monasticism went through gradual changes, ${ }^{156}$ and only in the Western Church of the $12^{\text {th }}$ century, did it turn into a twelve month novitiate. ${ }^{157}$ The novitiate became compulsory in the western monasteries only with the regulations established at the Council of Trent (the third period under Pope Pius IV, 1562-1563). ${ }^{158}$ The Council of Trent obliged all monastic families to introduce one year of novitiate and to fix the age for entering the monastery at sixteen, otherwise monastic profession was considered invalid. ${ }^{159}$

The Eastern Church carried on with one trial period, "becoming obedient," for all candidates, in which the authenticity of the vocation was verified (dokimasia). ${ }^{160}$ As in the Western Church so in the Eastern Church, the length of the trial period changed

156 J. Leclercq, Deux opuscules sur la formation des jeunes moines, "Revue d'Ascétique et de Mistique" 33 (1957), p. 387-399; G. Penco, Un nuovo manoscritto italiano della "Regula Magistri", "Benedictina» 18 (1971), p. 227-230.

157 J. Leclercq, Noviziato, 1: Nella storia della spiritualità, [in:] Dizionario degli Istituti di Perfezione, vol. 6, a cura di G. Rocca, Roma 1980, p. 442-443.

158 A. Boni, Noviziato, 2: Legislazione, 1: Evoluzione dottrinale, [in:] Dizionario degli Istituti di Perfezione, vol. 6, op. cit., p. 449.

159 The Council of Trent, session 25/A, Decree on regulars and nuns ch. 15: "In no religious order whatever, shall the profession, whether of men or women, be made before the age of sixteen years is completed; nor shall any one be admitted to profession, who has been less than a year under probation from the time of taking the habit. And any profession made sooner than this shall be null; and shall not superinduce any obligation to the observance of any rule, or of any religious body, or order; or entail any other effects whatsoever." http:// history.hanover.edu/texts/trent/ct25.html (20.08.2012).

160 Pl. de Meeester, De monachico statu juxta disciplinam byzantinam statuta, selectis fontibus et cum commentariis instructa, Città del Vaticano 1942, p. 349-366 (Collectio Sacra Congregazione per la Chiesa Orientale, Fonti, series 2, vol. 10); H. Jaeger, Examinatio (Épreuve de la foi), 3: Dans la Spiritualité monastique, [in:] Dictionnaire de Spiritualité, vol. 4/2, Paris 1961, 1861-1863; cf. Иеродиакон Никон (Горохов), Вступление в монашество и выход из него. Часть 9, http://rusk.ru/st.php?idar=155894 (6.07.2009). 
with time. Caesar Justinian prescribed a three-year trial, but this law (Novella V,2; CXXIII,35) applied only to candidates who were unknown to the hegumen of the monastery. The Patriarch of Constantinople, John Scholasticus (567-577), incorporated the aforementioned law to the statute book Synagoge L titulorum i do Collectio LXXXVII capitulorum which laid foundations for Byzantine Law. In turn, Caesar Leo VI the Wise, changed the requisite age to ten years (Novella 6). Eastern Church legislation regarding the minimum age of candidates depends on the autocephalus churches. For instance, legislation of the monks of Mount Athos set 18 years of age as the minimum age for admission to the monastery, while the Russian imperial law fixed the ages of 25 for those who completed theological studies and for clerics, of 30 for other male candidates, and of 40 for female candidates for monkhood. ${ }^{161}$

\section{The incorporation phase}

That phase completed the rite of passage, as the candidate was granted new monastic and ecclesiastical status during a ceremony of monastic profession. Monastic profession constituted a turning point for the candidate who officially abandoned the life of an ordinary Christian and began the monastic life. Once he made monastic profession, the monk became fully integrated into the monastery.

The first coenobitic rule, that is the Rule of St. Pachomius, did not mention the rite of monastic profession. So, the candidate became a pachomian monk when he declared provisionally that he wished to renounce the world and to join the community of brothers, when he successfully completed the trial at the gate, when he

\footnotetext{
161 Pl. de Meeester, De monachico statu juxta disciplinam byzantinam statuta..., op. cit., p. 356-406; J. Gribomont, Professione. IV. Il diritto bizantino, [in:] Dizionario degli Istituti di Perfezione, vol. 7, a cura di G. Rocca, Roma 1983, p. 892-894.
} 
74 The studies regarding monasticism and voluntary poverty...

learned Lord's Prayer and a few psalms, when he gave an account of himself to the abbot, when he was ready to disown his parents and renounce his possessions and when he was prepared to observe the monastic disciplines. ${ }^{162} \mathrm{~A}$ key moment in an admission process took place when the community decided that the candidate "satisfies all exigencies" and "consumed in every good deed, he will be able to be with the brothers." 163 The ceremony of divesting his lay clothes and dressing with the habit took place outside the organ gallery, and clothes that the candidate brought were given to the superior by the doorman. The monk already clothed in the monastic attire, was led by the doorman "to the presence of all the brothers," who "will make him sit in his assigned place."164

The candidate could become a monk once his superiors found his motivation satisfactory. The re-clothing ceremony and the entry to the place of prayer as a fully-fledged monk were formal symbols of the transition to monkhood. The Rule of St. Pachomius did not mention any formal declaration that should be made during the clothing ceremony or during the entry to the oratory, as all declarations - "to quit the world," to join the community of brothers and "to quit his relatives and undervalue material richness" - were made earlier. It cannot be said that there was any particular liturgical context, as the admission to the community of brothers took place while the candidate was being clothed with the habit and while he was taking his assigned seat. As Jean Gribomont, OSB, rightly noticed, the pachomians frequently emphasised the importance of commitment to the monastic life but the promise to observe the rule was

\footnotetext{
162 The Rule of St. Pachomius, Percept 49, PL 23, 73; ŹM 11, p. 137.

163 The Rule of St. Pachomius, Percept 49, http://www.seanmultimedia.com/Pie_Pachomius_Rule_1.html: "si enim viderint aptum ad orationem et ad omnia [...] ut instructus, atque perfectum in omni opere bono, fratribus copuletur.” PL 23, 73; ŹM 11, p. 137.

${ }_{164}$ The Rule of St. Pachomius, Percept 49, http://www.seanmultimedia.com/Pie_Pachomius_Rule_1.html: "ut orationis tempore adducat eum in conspectum omnium fratrum: sedebitque in loco, in quo ei praeceptum fuerit.” PL 23, 73; ŹM 11, p. 137-138.
} 
neither formal nor public. ${ }^{165}$ Subsequent pachomian monks talk in general about the ways to keep/observe the law of community in front of God and people (Theodor, born in 314/315, died in 368), about keeping covenant with God (Horsiesi, died after 387), about celebrating covenant with God in a holy place and declaring covenant (Shenoute of Atrip, born in 334/335, died in 425). In brief, they cared more about obeying commandments as a way of keeping covenant with God than making any special vows. ${ }^{166}$

The Lerins Rule of Four Father, which followed pachomian monasticism and belonged to the first generation of monastic rules, ${ }^{167}$ did not mention a formal act of profession, and instead only suggested an assessment of the candidate. ${ }^{168}$ The transition from the world of lay Christians to the monastic world was symbolised by the renunciation of all worldly goods ${ }^{169}$ and the renunciation of pride (such teachings were given to poor candidates). ${ }^{170}$ When the candidate demonstrated that he was able to obey the will of others and that he was humble ${ }^{171}$ and patient, ${ }^{172}$ he went through a one week trial outside the door of the monastery. ${ }^{173}$ Then, if he displayed stead-

165 J. Gribomont, Professione, 2: La tacita professione nei primi secoli, [in:] Dizionario degli Istituti di Perfezione, vol. 7, op. cit., p. 886.

166 Cf. A. Veilleux, La liturgie dans le cénobitisme pachômien au IVe siècle, Roma 1968, p. 199-225 (Studia Anselmiana, 58); V. Desprez, Cenobityzm pachomiański, ŹM 11, p. 15-99.

167 A. De Vogüé, Les règles monastiques anciennes (400-700). Typologie des sources du moyen âge occidental, Turnhout 1985, p. 13-15.

168 The Rule of Four Fathers, 2,16: “de saeculo convertuntur teneri debeat.” PL 103, 437; ŹM 3, p. 44.

169 The Rule of Four Fathers, 2,17: "amputandae sunt primo ab hujuscemodi divitiae saeculi." PL 103, 437; ŹM 3, p. 45.

170 The Rule of Four Fathers, 2,18-19.21: "et si quis pauper converti videatur, habet et ipse divitias, quas amputare debeat, quas Spiritus sanctus ostendit per Salomonem dicens: Odit anima mea pauperem superbus, et divitem mendacem (Ecc. XXV). Et alio loco dicit: Sicut vulneratum superbum (Psal. LXXXVIII) [...] ut si pauper convertitur, primo exponat sarcinam superbiae.” PL 103, 437; ŹM 3, p. 45.

171 The Rule of Four Fathers, 2,23: “debet ante omnia humiliter imbui." PL 103, 437; ŹM 3, p. 45.

${ }_{172}$ The Rule of Four Fathers, 2,24, PL 103, 437; ŹM 3, p. 45.

173 The Rule of Four Fathers, 2,25-26: PL 103, 437; ŹM 3, p. 45. 
The studies regarding monasticism and voluntary poverty...

fastness and patience, ${ }^{174}$ he was instructed by the superior about the principles of living with the brethren and he was officially admitted to the monastic community as a fully-fledged monk. ${ }^{175}$ As in the case of the Rule of St. Pachomius, neither here have we got any reference to a liturgical act. The rite of profession just consisted of the reception of the candidate by the superior to the monastery, once the former successfully completed the probationary period. The moment of transition was described as ["convertion out of the world"] 176 "breaking free of darkness." 177 As Salvatore Pricoco noted, for the Lerins monk, joining the secluded monastery was an act of liberation resulting in inner peace which made his circumstances similar to life of angels. ${ }^{178}$

Neither did Basil the Great include in his rules any description of the act of monastic profession, which formally applied to all candidates for monkhood. Only in his Greater Rules, chapter 15, discussing the case of children brought up to become monks, he talk-

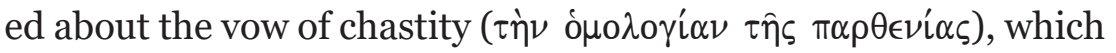
should be taken when children reach the age allowing them to arrive at this decision consciously and the decision should stem from their own convictions and beliefs. ${ }^{179}$ The under-aged wishing to take the vows should do so in the presence of the bishop acting as the official superior of the $\mathrm{Church}^{180}$ and after the probationary period. So taking the vows of chastity was a rite of passage after which

174 The Rule of Four Fathers, 2,27, PL 103, 438; ŹM 3, p. 45.

175 The Rule of Four Fathers, 2,28, PL 103, 438; ŹM 3, p. 45.

176 The Rule of Four Fathers, 2,16, “de saeculo convertuntur.” PL103, 437; ŹM 3, p. 44.

177 The Rule of Four Fathers, 2,25, "de saeculi hujus illecebris liberari voluerint." PL103, 437; ŹM 3, p. 45.

178 S. Pricoco, L'isola dei santi. Il cenobio di Lerino e le origini del monachesimo gallico, Roma 1980, p. 182.

179 Basil the Great, Greater Rules, 15,4, MPG 31, 956; ŹM 6, p. 98.

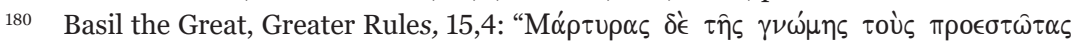

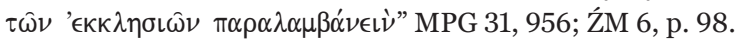


a candidate became a fully-fledged Basilian monk. ${ }^{181}$ Unfortunately, the rules of St. Basil did not provide the description of the equivalent monastic profession for adults. Unfortunately, in the rules of St. Basil, there is no reference to the equivalent monastic profession for adults. It can be assumed that, as in the case of youngsters, the decision to take vows should be taken independently, consciously and of one's free will, and one became a monk once he publicly pledged celibacy and chastity. In his other works, Basil stated that joining the monastery and becoming a monk should take place in the presence of witnesses, and that the violation of publically made pledges should be punished. ${ }^{182}$ However, the aforementioned legal conditions concerning taking the vows of chastity by the underaged should not be treated as a religious act, which was something prior to that. ${ }^{183}$

The rules of St. Augustine of Hippo did not mention the formal rite of monastic profession either. ${ }^{184}$ One probably became the Augustinian monk upon the successful completion of preliminary test of humility and unanimity, ${ }^{185}$ which was then confirmed by the renunciation of private property. ${ }^{186}$

The rite of monastic profession was described for the first time in the Rule of the Master. Before making monastic profession, the postulant listened to the rule, promised to observe its prescriptions (R.M. 87,1-4) and renounced property (R.M. 87,5-65). The day before profession, upon completion of the two months probationary

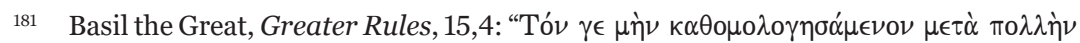

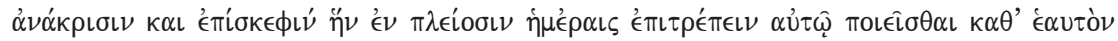

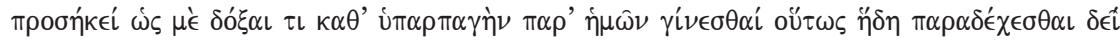

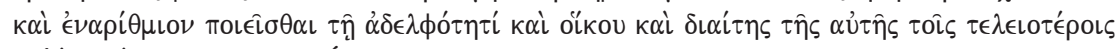
$\mu \in \dot{v} \in \xi_{0 \nu} \tau \dot{\alpha} "$ MPG 31, 956; ŹM 6, p. 99.

182 Cf. Basil the Great, Letter 46; Letter 199; Letter 217.

183 J. Gribomont, Professione, 2: La tacita professione nei primi secoli, op. cit., p. 88.

184 A. De Vogüé, Professione, 6: La professione in Occidente (secoli IV-IX), [in:] Dizionario degli Istituti di Perfezione, vol. 7, op. cit., p. 906-907.

185 Augustine of Hippo, Praeceptum, 1,2, NBA 7/2, 30; ŹM 27, p. 155.

186 Augustine of Hippo, Praeceptum, 1,3-8, NBA 7/2, 30.32; ŹM 27, p. 155-157.
} 
The studies regarding monasticism and voluntary poverty...

and reflection period, the postulant promised again in front of the abbot to observe the rule. ${ }^{187}$ The ceremony itself took place the following day in front of the oratory after a canonical prayer, called Prime, was said and while the abbot with brothers were leaving the oratory. Then, the postulant kneeling at the threshold of the oratory lowered his head to abbot's knees (R.M. 89,3), seized his robe (R.M. 89,5) and humbly asked him for permission to make profession, saying: "I have something to propose, first to God and this holy oratory, then to you and the community"(R.M. 89,6). In the meantime, the brothers were praying for the postulant. ${ }^{188}$ The abbot then replied: "Make known what it is." 189 The postulant made profession by uttering the words of the vows: "I wish to serve God in your monastery through by the discipline of the Rule read to me." 190 Then a dialogue between the novice and the abbot took place. The abbot asked: "And this is you pleasure?" to which the novice replied: "First it is God's, so then also mine." ${ }^{191}$ Then the abbot replied to the novice which he henceforth called brother:

Mark well, brother, you are not promising anything to me, but to God and to this oratory and to this holy altar. If in all things you obey the divine precepts and my admonitions, on the day of judgement you will receive the crown of you good deeds, and I myself shall gain some remission of my sins for having encouraged you to conquer the devil along with the world. But if you refuse to obey me in anything at all, see I am calling the Lord to witness, and this community will also give testimony in my favour on the day of judgment that, as I said before, if you do not obey me in anything at all, I shall go free at the judgement

\footnotetext{
187 The Rule of the Master, 89,1-2, trans. L. Eberle, p. 258.

188 The Rule of The Master, 89,6, trans. L. Eberle, p. 258.

189 The Rule of The Master, 89,7, trans. L. Eberle, p. 258.

190 The Rule of The Master, 89,9, trans. L. Eberle, p. 258.

191 The Rule of The Master, 89,9-10: "Cum responderit Abbas, dicens: 'Et hoc placet tibi,' subsequatur futurus discipulus: 'Hoc primo Deo, sic et mihi'.” Trans. L. Eberle, p. 258.
} 
of God and you will have to answer for your soul and for your contempt. ${ }^{192}$

After these words, the newly professed bestowed his property on the monastery by the inventory of donation ("donatio") that he placed on the altar. ${ }^{193}$ The ceremony ended in prayer, all participants gave one another the sign of peace, and the abbot took the inventory of donation from the altar. ${ }^{194}$ The new disciple was placed under authority of the superior ("praepositus") who was to introduce the newly professed into monastic structures. ${ }^{195}$ This rite of monastic profession applied to all candidates: conversi, laymen and priests. ${ }^{196}$

According the Rule of St. Benedict, monastic profession took place after a one year probation and it bound the postulant to the monastery and to the form of life that he professed. ${ }^{197}$ The ceremony of profession took place in the oratory, ${ }^{198}$ where the received brother was to "promise in the presence of all, before God and His saints, stability, the conversion of morals, and obedience."199 Should

192 The Rule of the Master, 89,11-16, trans. L. Eberle, p. 258-259.

193 The Rule of the Master, 89,17-23, trans. L. Eberle, p. 259.

194 The inventory of donation was included in the abbot's will (together with other documents) so that it was clear to everybody that all donations belonged (also from a legal point of view) to the monastery governed by the abbot: The Rule of the Master, 89,31-35, trans. L. Eberle, p. 260.

195 The Rule of the Master, 89,24-28, trans. L. Eberle, p. 259-260.

196 A. De Vogüé, Professione, 6: La professione in Occidente (secoli $I V-I X$ ), op. cit., p. 911.

197 The Rule of St. Benedict, 58,14-15: "tunc suscipiatur in congregatione, sciens et lege regulae constitutum quod ei ex illa die non liceat egredi de monasterio nec collum excutere desu iugo regulae." SCh 182, 628; English transl.: "let him be received into the community, knowing that he is now placed under the law of the Rule, and that from that day forward it is no longer permitted to him to wrest his neck from under the yoke of the Rule." The Rule of St. Benedict, 58.14-15, http://www.ccel.org/ccel/benedict/rule2/files/rule2.html.

198 The Rule of St. Benedict, 58,17, http://www.ccel.org/ccel/benedict/rule2/files/ rule2.html.

199 The Rule of St. Benedict, 58, http://www.ccel.org/ccel/benedict/rule2/files/ rule2.html. 
The studies regarding monasticism and voluntary poverty...

he ever breach his promise, he was to be condemned by God. ${ }^{200} \mathrm{He}$ was then to make a statement ("petitio") of his promise, written and signed with his own hand, and place it on the altar, which publicly confirmed profession. ${ }^{201}$ After the final payer of the monastic community, ${ }^{202}$ the postulant became officially the Benedictine monk. ${ }^{203}$ The renunciation of property (either by distributing it among the poor or by bestowing it on the monastery $)^{204}$ and the clothing with the habit ${ }^{205}$ were the final indication of the change of status.

As Adalbert De Vogüé OSB, noticed neither Master nor Benedict used the term "professio" (meaning: a public statement, monastic profession), and only once was the term "profiteri" used (meaning: to profess publicly, to declare $R M 7,3=R B 5,3$ : "propter servitum sanctum quo professi sunt"). What is more, these terms were used in the spiritual part of the documents. The institutional part, on the other hand, used the verb "promittere" (meaning: to promise, to pledge) to describe the act that took place during monastic profession. ${ }^{206}$ The Rule of St. Benedict followed the basic structure of monastic profession as described in the Rule of the Master, but

200 The Rule of St. Benedict, 58,18: "coram Deo et sanctis eius, ut si aliquando aliter fecerit, ab eo se damnandum siat quam inridit." SCh 182, 630 [English translation: "promise in the oratory, in the presence of all, before God and His saints, stability, the conversion of morals, and obedience, in order that, if he should ever do otherwise, he may know that he will be condemned by God «Whom he mocketh»." The Rule of St. Benedict, 58, http://www. ccel.org/ccel/benedict/rule2/files/rule2.html].

201 The Rule of St. Benedict, 58,19-20, SCh 182, p. 630; English translation: "Let him make a written statement of his promise in the name of the saints whose relics are there, and of the Abbot there present. Let him write this document with his own hand; or at least, if he doth not know how to write, let another write it at his request, and let the novice make his mark, and with his own hand place it on the altar." The Rule of St. Benedict, 58, http:// www.ccel.org/ccel/benedict/rule2/files/rule2.html.

202 The Rule of St. Benedict, 58,21-22, SCh 182, 630; ŹM 40, p. 483.

203 The Rule of St. Benedict, 58,23, SCh 182, 630; English translation: "and from that day let him be counted in the brotherhood.” The Rule of St. Benedict, 58, http://www.ccel. org/ccel/benedict/rule2/files/rule2.html.

204 The Rule of St. Benedict, 58,24-25, SCh 182, 630.632; ŹM 40, p. 483.

205 The Rule of St. Benedict, 58,26, SCh 182, 632; ŹM 40, p. 483.

206 De Vogüé, La professione in Occidente (secoli IV-IX), 1: Il termine "professio», [in:] Dizionario degli Istituti di Perfezione, vol. 7, op. cit., p. 906. 
the stages themselves were simplified. The ceremony of profession took place in the oratory but there were no particular guidelines regarding the time of the day or the liturgical context. Perhaps, as A. de Vogüé suggests, the ceremony of profession of adults was analogous to the oblation of children ( $R B$ 59) during the service, but this is just a hypothesis. ${ }^{207}$

Placing of the written document ("petitio") on the altar in the Rule of St. Benedict) was equivalent to donation, "donatio," described in the Rule of the Master. The aforementioned rite of profession, which was connected with the act of donation and was based on the dialogue between the postulant/candidate and the abbot, was most probably related to the concept of "stipulatio" - stipulation (the basic form of contract in Roman law). "Stipulatio" was the oral promise to provide service in the format of question and answer between a stipulator ("stipulator") and a promisor ("promissor"). For it to be valid, a correspondence between question and answer was necessary. Roman law provided for a written stipulation and a stipulation evidenced in writing. In the written form, a stipulator had to ask: "Dari spondes?" to which a promisor had to reply correspondingly: "Spondeo." The stipulation evidenced in writing was a legal practice enforced at the end of the Republic. In public law, stipulation served to make peace or covenant; in marriage law, it was used to promise a daughter in marriage. Once the contract was completed, written and contained all necessary clauses, it was read to a future promisor by a stipulator. Stipulation process usually ended with a question: "Ea quam supra sunt, promittis?," to which the promisor was to answer: "Promitto." It is therefore highly possible that the dialogue-like promise included in the Rule of

207 A. De Vogüé, La professione in Occidente (secoli $I V-I X)$, 2: L'atto rituale, op. cit., p. 912; cf. P. M. Ernetti, La professione monastica secondo S. Pacomio, S. Basilio, S. Cassiano, S. Benedetto, "Vita Monastica" 11 (1957), p. 152-161; 12 (1958), p. 3-12. 
The studies regarding monasticism and voluntary poverty...

the Master and the Rule of St. Benedict was the monastic adaptation of stipulation. ${ }^{208}$

What is more, Richard Kay demonstrated that the change of the term from «donatio» to "petitio» in the western monastic rules was influenced by the emerging legislation of the Caesar Justinian (Novella 5,5 from 20 March 535), according to which the postulant's possessions became property of the monastery from the moment he joined it. This is why, once this law was issued after 537, the confirmation of the admission to the monastery through the rite of profession was a mere formality. However, the territories that were not yet occupied by the Byzantine army at that time (between 537 and 553) were regulated by the older monastic legislation, taken by Benedict from the Rule of the Master, that is by so called "donatio" - a regulation/legislative act that required a novice to bestow a donation on the monastery. ${ }^{209}$

According to the first monastic rules (of St. Pachomius, of St. Basil, of Augustine, of the Four Fathers), the incorporation to the monastic community occurred when the postulant made a promise in front of the abbot to leave the world and to enter the monastery and when he successfully completed the preliminary trial. Therefore, at that point, the candidates joining the monastery did not have to make any ecclesiatico-legal declaration. Only later did monastic profession come into existence and became such a declaration. Moreover, the admission rather did not have any liturgical connotations and the transition from the world of lay Christians to the monastic community was symbolised by the renunciation

\footnotetext{
208 I. Herwegen, Geschichte der Benediktinischen Professformel, [in:] Studien zur Benediktinischen Profess, 2, Münster 1912, p. 38-39 (Beiträge zur Geschichte des Alten Mönchtums und des Benediktinerordens, 3); M. Augé, La professione religiosa in Occidente, [in:] Scientia liturgica. Manuale di liturgia, vol. 4: Sacramenti e Sacramentali, a cura di A. J. Chupungco, Casale Monferrato 1998, p. 327-328.

209 R. Kay, Benedict, Justinian and Donations «mortis causa» in the «Regula Magistri», "Revue Bénédictine" 90 (1980), p. 169-193; A. De Vogüé, La législation de Justinien au sujet des moines, "Mabillon" 14 (2003), p. 139-151.
} 
of property. The first monastic rule which described the formal rite of passage in the form of monastic profession was the Rule of the Master. The formal ceremony of monastic profession was also described in the Rule of St. Benedict. The extended forms of monastic vows therefore started to take on/acquire distinctive liturgical characteristics, and while in the Rule of the Master, monastic profession was made in the presence of the abbot and brothers in front of the oratory, in the Rule of St. Benedict, it was made in the presence of the abbot and brothers but in the oratory. Until the $6^{\text {th }}$ century in Church, no description of adult monastic profession during the liturgy of Holy Mass had existed. The written promise made by the novice confirmed the change of his status, and whereas in the Rule of the Master it took the form of the donation ("donatio"), in the Rule of St. Benedict, it took the form of the document confirming publicly monastic profession ("petitio"). This document was accompanied by either bestowing a donation on the monastery or distributing possessions among the poor. The sacralisation and juridification of the rite of profession, manifested in the monastic rules of the first half of the $6^{\text {th }}$ century, was the result of the growing feudalisation and the codification of liturgy that began in the $6^{\text {th }}$ century.

\section{Conclusion}

The rites of passage accompanying initiation to monastic life definitely contributed to the re-evaluation of religious life. A candidate, giving up his life, became a monk and was invited to be a part of the world that was considered more sacred than the one he had ritually left behind. Initiation rituals introduced the candidate for monkhood to the new monastic life, which frameworks were defined by the rule of a given monastery. Upon completion of all stages of the formation, the candidate became a different 
The studies regarding monasticism and voluntary poverty...

person - a monk - and he acquired a new position both in the monastery and in the Church. Employing Arnold van Gennep's classification of the rites of passage, we can confirm that the rites of passage, which pertain to initiation to monastic life and are described in the ancient monastic rules, are classified along two criteria: gender and religion. Gender is an evident criterion as in the analysed rules there was not any universal model of initiation for both men and women: in fact, only monastic initiation of men was described. As far as the religious criterion is concerned, the candidate for monkhood passed from the profane world ("profanum"), which he formally renounced, to the sacred world ("sacrum"), represented by the monastic community.

In the initial stage of the separation, that is during the trial at the gate of the monastery, the candidate: 1) expressed his willingness to renounce the word and to join the monastic community of Coenobites (the Rule of St. Pachomius, chapter 49); 2) expressed his desire to be freed from the darkness of the world (the Rule of Four Fathers); 3) renounced himself and forgot all that had been before (St. Basil, The Greater Rules, 6,1); 4) renounced material goods (St. Augustine of Hippo, Praeceptum, 1,2). Subsequent rules, dating back to the $6^{\text {th }}$ century, proposed examining reasons behind candidate's will to join the monastery (the Rule of the Master, 87,1-2; the Rule of St. Benedict, 58, 1-2), and there was a tendency to extend the preliminary formation period of candidates. Renouncing the world was manifested through renouncing the property (the Rule of St. Pachomius - Commandments; the Greater Rules 6,1-2; Ordo monasterii 4 - Praeceptum 1,2-8; the Rule of The Four Father 2,29-33; the Rule of the Master 87,5-18; 91,1-7; 45-47; the Rule of St. Benedict 58,9.12-13;14-24; 59,3-4). Most of the early monastic rules, except for the Rule of St. Benedict, demanded the renunciation of property from candidates at the very beginning of their life in the monastery. As for the last sign of the separation, that is the monastic habit, half of the rules treated it as 
a symbol of becoming a monk and joining the monastic community (the Rule of: St. Pachomius, the Master, St. Benedict), while the others just mentioned modest clothes, not necessarily understood as the monastic attire.

The transition phase, understood in the monasteries as the second trial, was not included in the first coenobitic rules (the Rule of St. Pachomius, the Rule of St. Basil, the Rule of St. Augustine, the Rule of Four Fathers) which spoke of just one, quite short, preliminary trial. It was until the first half of the $6^{\text {th }}$ century (the Rule of the Master, the Rule of St. Benedict) that the formalised transition period appeared in monastic legislation. The length of this period depended on the social status of the candidate (whether he was a priest, a nobleman, a conversus or a layman). The incorporation phase in the first rules took place straight after the preliminary period and after the pledge to renounce the world taken by a candidate. The first rules that introduced the rite of passage in the form of monastic profession were the Rule of the Master and the Rule of St. Benedict dating back to the $6^{\text {th }}$ century. The evident change of monastic legislation, which regarded the extension of the transition period and the formalisation of monastic profession, occurred at the end of Antiquity and was most probably the result of the feudalisation of the Western Church and theocratisation of the Eastern (Orthodox) Church.

The authors of the first monastic rules emphasised the moment of transition of the candidate for monkhood from the lay world to the world of the monastery. This transition was theologically motivated by the desire to preserve the Gospel and to devote oneself to the community of men of the same evangelical faith. Hence, the monks, who called themselves brothers, all adopted equal criteria of Christian life, which were included in the rule they decided to accept. The transition from the world inhabited by the majority of Christians to the world of minority, that is to the world of the $3^{\text {rd }}$ and $4^{\text {th }}$ century monks, was characterised by a notable socio-religious 
The studies regarding monasticism and voluntary poverty...

context: the world that monks were leaving behind did not observe the common rules of everyday Christian life. 


\section{IV}

\section{Wealth and poverty in the Western Imperial Church of the Fourth and Fifth Centuries - the attempt to synthesize the issue*}

For the $1^{\text {st }}$ and $2^{\text {nd }}$ century Christians, the idea of wealth and poverty was associated with the evangelical ideals of community, i.e. voluntary renunciation of earthly possessions (Lk 12:33; Mt 19:21-27), collective property (Acts 4:32 - 5:11) and collective feelings expressed through brotherliness (Acts 4:32; Rom 5:12-21; 2 Cor 1:7; Heb 10:33; 1 Pet 4:13). That triple ideal of communal living was perfectly accomplished by Jesus (Acts 3:14; Phil 2:6-11; Col 1:15). ${ }^{1}$ The later, Christian attempt to meet these standards of acquiring, possessing and using material goods was undoubtedly easier in small Christian communities that existed up to the third century, ${ }^{2}$ than it was in the mass Imperial Church of the $4^{\text {th }}$ or $5^{\text {th }}$ century. During the first two centuries of Christianity, there existed two basic views

* This article was originally published under the title: Kwestia bogactwa $i$ ubóstwa $w$ Kościele imperialnym na Zachodzie w IV i V wieku - próba syntezy zagadnienia, "Vox Patrum” 31 (2011) nr 56, p. 495-515.

1 J. Leclercq, "Il s'est fait pauvre”. Le Christ modèle de pauvreté volontaire d'après les Pères, "La Vie Spirituelle” 117 (1967), p. 501-518.

2 V. Grossi, La chiesa preconstantiniana di fronte a la povertà, [in:] L'annuncio del Regno ai poveri. Atti della XV Sessione di formazione ecumenica organizzata dal Segretariato attività ecumeniche (S.A.E.), La Mendola (Trento), 30 luglio-7 agosto 1977, Torino 1978, p. 69-101. 
The studies regarding monasticism and voluntary poverty...

about material goods. The first one, practical-positive, highlighted the divine origin of all material goods and, therefore, postulated their proper use. The second view, ascetic-negative, highlighted the risk that material goods may entail and, therefore, postulated their renunciation through living in poverty, just like Jesus. ${ }^{3}$

Since obtaining legal personality in the Roman Empire in the year 312, Christian Church (especially in the west part of Imperium Romanum) was experiencing a whole range of sociological phenomena, like a decline of Roman colonization, decrease in population in the western lands of Roman Empire, phenomenon of patronage, development of Church property, decreasing life-span, malnutrition and a general deterioration of living conditions. ${ }^{4}$

However, for the Church fathers and early Christian writers of the $4^{\text {th }}$ and $5^{\text {th }}$ centuries, Christian soteriology constituted the referring point for the ideas of wealth and poverty - just like it had been in the past. In the Patristic Period ( $1^{\text {st }}$ to $7^{\text {th }}$ century), social economic or political Church doctrines could not yet be identified on the basis of the early Christian writers' opinions. ${ }^{5}$

3 T. Mauro, P. Alieto, Retto uso delle ricchezze nella tradizione patristica. Clemente d'Alessandria, Basilio di Cesarea, Gregorio di Nazianzo, Gregorio di Nissa, Giovanni Crisostomo, Ambrogio di Milano, Agostino d'Ippona, Cromazio d'Aquileia, Torino 1985; E. Dal Covolo, Riccheza e povertà nei primi tre secoli della Chiesa, [in:] Humanitas classica e sapientia cristiana, a cura di S. Felici, Roma 1992, p. 259-274; A. Rodziński, Bogactwo i ubóstwo w świetle myśli chrześcijańskiej pierwszych trzech stuleci, "Vox Patrum" 16 (1996) z. 30-31, p. 85-90; A. G. Hamman, Partage avec le pauvre, Paris 1998 (Les Pères dans la Foi, 72); D. Kasprzak, Bogactwo i bieda w starożytności chrześcijańskiej, [in:] Bogactwo i bieda. Próba refleksji humanistycznej, red. R. Borkowski, Kraków 2004, p. 25-32.

4 J. Śrutwa, Majątek kościelny i jego funkcja społeczna $w$ Afryce Łacińskiej II-V wieku, "Roczniki Teologiczno-Kanoniczne" 28 (1981) z. 4, p. 5-28; G. Ryś, Majątek kościelny w starożytnym prawodawstwie synodalnym, [in:] Charisteria Tito Górski oblata. Studia i rozprawy ofiarowane profesorowi Tytusowi Górskiemu, red. S. Stabryła, R. M. Zawadzki, Kraków 2003, p. 219-227; M. McCormick, Narodziny Europy. Korzenie gospodarki europejskiej 300-900, tłum. A. Bugaj et al., Warszawa 2007, p. 38-50.

5 M. G. Mara, Richezza e povertà nel cristianesimo primitivo, Roma 1991, p. 25. Bibliography on the subject of possession, wealth and poverty in the patristic period is extensive; the most significant works on these subjects are: L. Lallemand, Histoire de la charité, vol. 1-4, éd. A. Picard, Paris 1902-1912; E. Bruck, Kirchenväter und soziales Erbrecht. Wanderungen religiöser Ideen durch die Rechte der östlichen und westlichen 
Nevertheless, the teachings of some theologians of the $4^{\text {th }}$ and $5^{\text {th }}$ centuries had an enormous influence on the formation of later social doctrines in the Catholic Church. In this article, I would like to present the reader with the approach towards the idea of wealth and poverty from the perspective of representative Christian theologians in the Western Church of the $4^{\text {th }}$ and $5^{\text {th }}$ centuries, both orthodox (I chose two Doctors of the Western Church, namely, St. Ambrose, Bishop of Milan and St. Augustine, Bishop of Hippo, the representatives of orthodox monasticism) as well as heterodox, from the ascetic movement of Pelegians.

\section{The acceptance of the ownership right}

In the $3^{\text {rd }}$ century Christianity worked out three different opinions about the ownership and the right to use material goods: optimistic, pessimistic and realistic. The optimistic thought considered wealth a means to sanctification and a proof of Divine Protection

Welt, Heidelberg 1956, p. 1-75; Riches et pauvres dan L'Église ancienne, éds. Q-J. France, A. Hamman, Paris 1962; M. Hengel, Property and riches in the Early Church. Aspects of a social history of Early Christianity, London 1974; J. de Santa Ana, Good news to the poor. The challenge of the poor in the history of the Church, Maryknoll (NY) 1979; C. Lindberg, Through a glass darkly. A history of the Church's vision of the poor and poverty, "The Ecumenical Review" 33 (1981), p. 37-52; AA. VV., Per foramen acus. Il cristianesimo antico di fronte alla pericope evangelica del "giovane ricco", Milano 1986 (Studia Patristica Mediolanensia, 14); J. A. T. McGuckin, The vine and the Elm Tree. The patristic interpretation of Jesus' teaching on wealth, [in:] The Church and wealth, eds. W. J. Sheils, D. Wood, Oxford 1987, p. 1-14 (Studies in Church History, 24); T. D. Hanks, Poor, poverty, [in:] Anchor Bible Dictionary, vol. 5, New York 1992, p. 403-424; M. J. De Vinne, The advocacy of empty bellies. Episcopal representation of the poor in the Late Empire, Stanford 1995; D. Janes, God and gold in Late Antiquity, Cambridge 1998; P. Brown, Poverty and leadership in the Later Roman Empire, Hanover (NH) 2002; D. Caner, Wandering begging monks. Spiritual authority and the promotion of monasticism in Late Antiquity, Berkeley 2002 (The Transformation of the Classical Heritage, 33); Les peres de l'Église et la voix des pauvres. Actes du 11e colloque de La Rochelle, les 2, 3 et 4 septembre 2005, éd. P. G. Delage, Association Histoire et Culture La Rochelle (France) 2006; Wealth and poverty in Early Church and society. Holy cross studies in patristic theology and history, ed. S. R. Holman, Grand Rapids 2008. 
The studies regarding monasticism and voluntary poverty...

in exchange for a life of pious devotion. The pessimistic view considered wealth to be a sin and affluence was a sentence of perdition. The realistic outlook, and at the same time a moderate one, prevalent in the fourth century, accepted material goods as intended by God, and as such given to the man, and considered them proper and essential in the earthly life. ${ }^{6}$ This differentiation of outlooks was the result of Church writers being influenced by the thoughts from the Old Testament and from Judaism as such, as well as by the pagan thought of the Greek and Romans. Christ's teachings would display only the moral scope of the ownership right, which belonged to the Natural Law and not to the Revealed Law. Nevertheless, it did not get into conflict with the Revealed Law as God is the source of both. ${ }^{7}$

One of the first theoreticians of the ownership right in the Imperial Church in the west was St. Ambrose, Bishop of Milan (born in 339 a.d. - died in 397 a.d.). ${ }^{8}$ In his treatise On Naboth, St. Ambrose claimed that God was the source of all good, therefore, for that reason, the goods were good. After all, they were God's creation and were meant for the use of all people. ${ }^{9}$ Material goods,

6 H. Gulbinowicz, Etyczne poglądy św. Ambrożego na dobra materialne i prawo własności, "Studia Warmińskie" 1 (1964), p. 262. H. Gulbinowicz, discussing the realistic attitude towards material goods, claims that the realistic attitude, upon a closer look, allows for an extension of thoughts in the Torah and the Old Testament prophets, who cared for the poor and did not consider material goods as evil in se. Therefore, they did not demand eschewing the goods nor disregarding them. They claimed that possessing goods do not cause eternal condemnation. The representatives of the realistic movement demanded that the owners of the goods made a good use of them i.e. employed the commandments of love given by Christ (Mt 5:7; 10:42; Lk 6:36);” cf. M. Żywczyński, Poglądy chrześcijan IV wieku na nierówność majątkową w świecie, “Życie i Myśl” 3 (1956), p. 39-47.

7 P. Christophe, L'usage chrétien du droit de propriété dans l'Écriture et la tradition patristique, Paris 1964, p. 19-20.

8 A more extensive study of St. Ambrose of Milan's idea of social life: V. R. Vasey, The social ideas in the works of. St. Ambrose. A study on De Nabuthe, Roma 1982 (Studia Ephemeridis Augustinianum, 17) (more about the private property in Ambrose's compare ch. 3: p. 105-182).

9 Ambrose of Milan, De Nabuthae, 1, 2, Opera Omnia di Sant'Ambrogio [below-quoted as OOSA], vol. 6, a cura di F. Gori, Milano-Roma 1985, p. 130, 132 (Polish transl.: Historia Nabota, red. R. Pankiewicz, Warszawa 1986, p. 26-27 [PSP 35]). 
such as the Earth, were inherent to the man. ${ }^{10}$ St. Ambrose distinguished between three categories of goods that were given to the man: goods of the soul, goods of the body and external goods. ${ }^{11}$ The goods of the soul and body were given exclusively to the man. On the other hand, the external goods - indispensable in this world existed so that the man could make a sensible use of them and reach the eternal life. ${ }^{12}$ And this would be reached if the man, apart from satisfying one's own needs, supported the needy. Otherwise, the goods were useless and wasted as such. ${ }^{13}$ If the owned material goods only stirred greed and desire to own more to satisfy the coveter, they became the source of sin, distancing the man from fulfilling God's will. ${ }^{14}$ St. Ambrose did not reject the right to private possession, quite on the contrary, proclaimed that anyone rejecting the right of ownership did not only violate the Natural Law but also the Law of God. ${ }^{15}$ On the other hand, the rich that did not help the poor or the needy, driven by their own benefits, would be rejected by God. ${ }^{16}$

Augustine of Hippo (born in 354 a.d. - died in 430 a.d.), ${ }^{17}$ also deduced the right of ownership from the positive human law, not

10 Ambrose of Milan, De Nabuthae, 1, 2, OOSA 6, 130 (Polish transl.: PSP 35, 26).

11 H. Gulbinowicz, Etyczne poglądy św. Ambrożego, op. cit., p. 264-265.

12 Ambrose of Milan, De Nabuthae, 7, 37, OOSA 6, 158 (Polish transl.: PSP 35, 38).

13 Ambrose of Milan, De Nabuthae, 12, 52, OOSA 6, 172 (Polish transl.: PSP 35, 44).

14 Ambrose of Milan, De Nabuthae, 2, 5, OOSA 6, 134, 136 (Polish transl.: PSP 35, 28); Ambrose of Milan, De Nabuthae, 6, 28, OOSA 6, 152 (Polish transl.: PSP 35, 35).

15 Ambrose of Milan, De Nabuthae, 3, 11, OOSA 6, 138 (Polish transl.: PSP 35, 29); cf. Ambrose of Milan, De Nabuthae, 5, 21, 25; Ambrose of Milan, De officis ministrorum, 1, $16,62-63$.

16 Ambrose of Milan, De Nabuthae, 6, 27, OOSA 6, 150 (Polish transl.: PSP 35, 34-35).

17 More extensively on Augustine's attitudes towards socio-economic issues: H. A. Deane, The Political and Social Ideas of St. Augustine, New York 1963; W. Kornatowski, Społeczno-polityczna myśl świętego Augustyna, Warszawa 1965; A. Eckmann, Troska o ubogich w nauczaniu i działalności świętego Augustyna, "Vox Patrum" 16 (1996) z. 3031, 161-182; D. Burt, Friendship and society. An introduction to Augustine's practical philosophy, Michigan 1999; R. W. Dyson, The pilgrim city. Social and political ideas in the writings of St Augustine of Hippo, Woodbridge 2001; S. Jóźwiak, Państwo i Kościót w pismach św. Augustyna, Lublin 2004. 
92 The studies regarding monasticism and voluntary poverty...

from the Revealed Law, since God created all men equal in status and without material or any other divisions, able to share love. ${ }^{18}$ Nonetheless, Augustine recognized personal property and condemned Manichaeans ${ }^{19}$ and the so called Apostolics ${ }^{20}$ for their rejection of personal property. The Bishop of Hippo also rejected the rigorous Pelagian interpretation of Evangelical Counsel of voluntary poverty (Mt 19:21); the encouragement from the counsel was treated by the Pelagians as an evangelical order. ${ }^{21}$ For Augustine, having material goods was bad and sinful, whereas the way men used goods, determined their character: the rich, humble and trusting in God were better than the haughty and poor. ${ }^{22}$

\section{The destination of material goods}

\subsection{The universal destination of goods}

From among all the Western Fathers, St. Ambrose spoke most comprehensively about the destination of material goods. The Bishop of Milan, just like other theologians from the patristic era, derived the law of the universal destination of goods from the Biblical rule that stated that God was the source of all good. ${ }^{23}$ His philosophy was supported with the concepts of justice (latin iustitia) and fraternity

18 Augustine of Hippo, In Iohannis Evangelium tractatus, 6, 23, Nuova Biblioteca Agostiniana [below-quoted as NBA], vol. 24/1, eds. A. Vita, E. Gandolfo, V. Tarulli, MilanoRoma 1985, p. 148.

19 Augustine Hippo, De moribus ecclesiae catholicae et de moribus manichaeorum, 1.34-1.35, NBA 13/1, eds. F. Decret, L. Alici, A. Pieretti, Milano-Roma 1997, p. 62.64.

20 Augustine of Hippo, De Haeresibus, 40, NBA 12/1, ed. M. Falcioni, Milano-Roma 2003, p. 92.

${ }_{21}$ Augustine of Hippo, Epistola, 157,23, NBA 22, ed. L. Carrozzi, Milano-Roma 1996, p. 614; cf. a Pelagian treatise of an anonymous author De Divitiis: PLS 1, coll. 1380-1418.

22 Augustine of Hippo, Sermo, 36, 5-7, NBA 29, 642; Augustine of Hippo, Ennaratio in Psalmum, 132, 4, NBA 28/1, 310.312.

${ }^{23}$ J. Bryja, Powszechne przeznaczenie dóbr $w$ nauce Ojców i pisarzy kościelnych IV $i$ V wieku, Częstochowa 2002, p. 55-95 (PWT in Wrocław, Rozprawy naukowe, 40). 
(latin fraternitas), which came down to the principles of solidarity and mutual love all of people. ${ }^{24}$ The Bishop of Milan referred to the stoic concept of worthy living in accordance with nature, which in consequence lead to the thesis that all people were equal. However, when the stoics offered mutual help and community living as elements of pantheism, Ambrose formulated the same principles on the basis of Evangelic love and the rational nature of the man. ${ }^{25}$ What is more, if nature bore fruit to all people, the law of nature would suggest that the earth was the common good to all. ${ }^{26}$ Employing the aforementioned division of human goods into the goods of the soul, body and the external goods, Ambrose stated that the goods in the form of food, clothes and money prevented the man from suffering material deficiencies in this life. ${ }^{27}$ The external goods - material ones - were supposed to serve the man, as was the purpose of the created things. ${ }^{28}$ Material goods allowed the man to live; therefore, the man was advised to use them moderately, avoid luxuries and unnecessary pleasures, for the wealth, though morally indifferent, was likely to become a source of $\sin .^{29}$

\subsection{Moderate and decent use of material goods}

In Christianity, since the treatise by Clement of Alexandria Who is the rich man that shall be saved?, there had existed an unbroken

24 V. R. Vasey, The Social Ideas in the Works of St. Ambrose, op. cit., p. 225-235; R. Pankiewicz, O Nabocie, PSP 35, 5; cf. Ambrose of Milan, De Nabuthae, 1, 2; 3, 11-12; 5,$23 ; 13,54$.

25 R. Pankiewicz, O Nabocie, 11-15; cp. Ambrose of Milan, De Nabuthae history, 5, 19. $23.25 ; 7,32.37 ; 8,40 ; 9,41 ; 10,45 ; 11,49 ; 13,56$.

26 Ambrose of Milan, De Nabuthae, 1, 2, OOSA 6, 130.132; PSP 35, 26-27; 3, 12, OOSA 6, 138.140; PSP 35, 26-27.

27 Ambrose of Milan, Expositionis Euangelii secundum Lucam, 7, 245, OOSA 12, a cura di G. Coppa, Milano-Roma 1978, p. 276.

28 Ambrose of Milan, De officiis, 3, 3, 19, OOSA 13, a cura di G. Banterle, Milano-Roma 1977, p. 284; cf. Ambrose of Milan, De excessu fratris sui Satyri, 2, 55.

29 Ambrose of Milan, De spiritu sancto, 3, 17, OOSA 16, a cura di C. Moreschini, MilanoRoma 1979, 272.274; Etyczne poglądy św. Ambrożego, red. H. Gulbinowicz, op. cit., p. 267. 
94 The studies regarding monasticism and voluntary poverty...

tradition of moderate and decent use of wealth. This thought may be briefly characterized in the following way: from the Christian point of view, it was decent to amass riches and use them, and the decent usage in this life did not exclude a rich Christian from the eternal life. ${ }^{30}$

Upon acknowledging the right of personal property ownership, Ambrose highlighted that from the point of view of the law of nature, material goods were intended for all people, the earth was an integral property of all people; nature created the law of community, and the right of ownership of an individual was an individual's usurpation. ${ }^{31}$ Therefore, owning private possession was not in conflict with Christian morality. However, Ambrose limited the owner's right to things that are inevitably necessary. Everything beyond the necessity constituted excess and was understood as taking food from other people's mouths ${ }^{32}$ and so the wealthy should share their fortune to help the poor, sick and orphans, as well as remain hospitable to strangers. ${ }^{33}$ St. Ambrose was the first Christian author to establish the concept of decent price, which he claimed should be determined with honesty, and not profit, in mind. ${ }^{34}$ Also, he propagated the rule of morally decent usage of material goods, i.e. cover your basic needs and give

30 C. Lindberg, Through a glass darkly. A history of the Church's vision of the poor and poverty, "Ecumenical Review" 33/1 (1981), p. 37-52; V. R. Vasey, The social ideas in the works of. St. Ambrose, op. cit., p. 156-164; J. A. McGuckin, The vine and the Elm Tree. The patristic interpretation of Jesus' teaching on wealth, [in:] The Church and wealth. Papers read at the 1986 summer meeting and the 1987 winter meeting of the Ecclesiastical History Society, eds. W. J. Sheils, Diana Wood, Oxford 1987, p. 1-14; cf. J. L. González, Faith and wealth. A history of Early Christian ideas on the origin, significance, and use of money, San Francisco 1990.

31 Ambrose of Milan, De officiis, 1, 28, 132, OOSA 13, 102.104 (Polish transl.: PAX 12, 66; cp. Ambrose of Milan, De Nabuthae, 12, 53); cf. H. Gulbinowicz, Etyczne poglądy św. Ambrożego, op. cit., p. 269.

32 Cz. Strzeszewski, Własność. Zagadnienia społeczno-moralne, Ośrodek Dokumentacji i Studiów Społecznych (ODiSS), Warszawa 1981 (private possessions in patristic teachings: St. Ambrose), p. 117-118.

33 Ambrose of Milan, De Nabuthae, 13, 57, OOSA 6, 176.178; PSP 35, p. 46-47.

34 Ambrose of Milan, De officiis, 3, 6, 37, OOSA 16, 296 (Polish transl.: PAX 12, 177). 
the excess to the poor. What was superfluous for the wealthy man, was necessary for the poor one..$^{35}$ In this world, the man depended on the earthly goods, however, from the perspective of Judgment Day, the man should eschew things that seemed redundant and inhibiting spiritual development. ${ }^{36}$ For the Doctor of Hippo the legal condition for personal property was their proper ownership, where "proper" was understood as in compliance with moral principles. ${ }^{37}$ According to St. Augustine, sharing the surplus of goods with the poor derived from justice. ${ }^{38}$ Material goods were simple products, which had not yet been described by Augustine as morally neutral. ${ }^{39}$ Goods could become either good or bad depending on the way they were used. Bad usage led to them becoming bad and, analogically, when they were used in good faith, they were to become good. ${ }^{40}$ If the owner used the possession immoraly, the ownership was repealed for such a perpetrator ${ }^{41} \mathrm{Cz}$. Strzeszewski explained that the reason why people used possessions in an improper way was because they had lost the grip of the hierarchy of the aims of life. He also pointed to the fact, that St. Augustine described the mistake concisely as frui utendis - the search for meaning in what was only the means in the pursue of higher ideals. ${ }^{42}$

35 Augustine of Hippo, Ennaratio in Psalmum, 147, 12-13, NBA 18/2, a cura di V. Tarulli, Milano-Roma $1993^{2}$, p. 824-828; PSP 42/z. 1, p. 348-350.

36 Augustine of Hippo, Sermo, 110, NBA 30/2, a cura di L. Carrozzi, Roma 1983, p. $365-372$.

37 Augustine of Hippo, Contra Adimantum manichaei discipulum, 18,1-19,2, NBA 13/2, a cura di G. Sfameni Gasparro, C. Magazzù, A. Consentino, Roma 2000, p. 198-204.

38 Augustine of Hippo, Sermo, 61, 3, NBA 30/1, a cura di L. Carrozzi, Roma 1983, p. 232; Augustine of Hippo, Ennaratio in Psalmum, 147, 12, NBA 18/2, p. 824.

39 D. J. Macqueen, St. Augustine's Concept of Property Ownership, "Rechereches Augustiniennes" 8 (1972), p. 187-229.

40 Augustine of Hippo, Sermo, 72, 4.5, NBA 30/1, a cura di L. Carrozzi, Roma 1983, p. 460, 462; cp. Augustine of Hippo, Sermones, 48, 8; 61, 3; 311, 9.

41 Cz. Strzeszewski, Własność, 119; cf. Augustyn z Hippony, Epistola, 153.

42 Cz. Strzeszewski, Własność, 120; cf. Augustine of Hippo, De diversis quaestionibus octoginta tribus, 30 . 
The studies regarding monasticism and voluntary poverty...

\subsection{Alms}

During the time when the Roman society faced, what we may call, the phenomenon of intensified stratification at the end of the fourth century, the persistent incitement to give alms to the needy might be observed in the written sources. Bishops, monks and layChristians alike encouraged to give alms. ${ }^{43}$ St. Ambrose went as far as to incite people to sell their goods and perform the act of mercy to help the needy. ${ }^{44} \mathrm{R}$. Pankiewicz suggested that Ambrose might have been under the influence of cynic-stoics and cynical-stoical asceticism of Epictetus, who held the wealth and the wealthy in high contempt footnote no. $45 .{ }^{45}$ The stoic streak in Ambrose's outlook on the society could be observed on the basis of how he exlained the etymology of the word humanitas. Humus, instead of homo, stood as the root of the word, where the former signified imitating Mother Earth, depicted as merciful to the living as well as to the dead. Therefore, mercy (latin: misericordia) became the foundation for beneficence (latin: beneficentia). ${ }^{46}$ The Gospel message undeniably influenced the concept of alms; the perfect merciful people should help the needy with their goods as far as it was necessary. ${ }^{47}$ The need to give alms was also the result of the principle about protecting the poor and needy against the mighty rich. Therefore, the bishop of Milan attacked all kinds of abuse and exploitation as the means to economic oppression. Giving alms, rather than be a private initiative, should become a social activity that would lessen the disproportions among the Roman society. ${ }^{48}$

\footnotetext{
43 R. Finn, Almsgiving in the later Roman Empire: Christian promotion and practice (313-450), Oxford-New York 2006, p. 34-115.

44 Ambrose of Milan, De Nabuthae, 14, 58, OOSA 6, 178; PSP 35, 47; cf. Ambrose of Milan, De officiis, 1, 11.39; 1, 30, 149; 2, 21, 109.

45 R. Pankiewicz, O Nabocie, op. cit., p. 19-20.

46 R. Pankiewicz, O Nabocie, op. cit., p. 23-24.

47 Ambrose of Milan, De Nabuthae, 14, 58, OOSA 6, 178; PSP 35, 47.

48 Ambrose of Milan, De Nabuthae, 7, 33.36-37: OOSA 6, 154.156-158; PSP 35, 36.37-
} 38; 8, 40: OOSA 6, 160.162; PSP 35, 39-40; 9, 41-10, 45: OOSA 6, 162.164-166; PSP 35, 
In Christianity, the alms should get the form of a direct, rather than indirect, help towards those who are truly in need of material support. ${ }^{49}$ When it comes to the moral virtues that should be prevalent in the process of giving alms, Ambrose advised that they be generosity, joy and humility. ${ }^{50}$ The poor should not feel humiliated to be given the alms. ${ }^{51}$ To the giver, the alms meant a spiritual gain, as the interest would be paid back by God on Judgment Day. ${ }^{52}$ Ambrose also warned against frauds and advised not to give alms with the vain purpose of putting on airs. Nor should the alms be given to strangers, if any relatives were in need. ${ }^{53}$

Also, Augustine of Hippo appealed to the rich Christians to give alms. ${ }^{54}$ In accordance with the patristic topos, ${ }^{55}$ the Doctor of Hippo justified the concept of alms on the grounds of the truth of faith, namely, that God was the owner of all material goods as well as on the grounds of the need for social justice. ${ }^{56}$ Upon inviting the faithful to give alms, Augustine preached that real goods belonged to those, who used them properly; therefore to those, who gave alms as opposed to those who did not. ${ }^{57}$ Augustine promoted alms-giving,

40-41; 12, 52-53: OOSA 6, 170.172; PSP 35, 44-45; 14, 59-60: 178.180; PSP 35, 47-48; 63: OOSA 6, 182.184; PSP 35, 49-50.

49 Ambrose of Milan, De officiis, 1, 30, 143: OOSA 13, 110; PAX 12, 70.

$50 \quad$ Ambrose of Milan, De Nabuthae, 8, 40: OOSA 6, 160.162; PSP 35, 39-40; H. Gulbinowicz, Etyczne poglądy św. Ambrożego, op. cit., p. 279.

51 Ambrose of Milan, De Nabuthae, 13, 54: OOSA 6, 174; PSP 35, 45.

52 Ambrose of Milan, De Nabuthae, 14, 58-60: OOSA 6, 178.180; PSP 47-48; 16, 6667: OOSA 6, 188.190; PSP 51-52.

53 Ambrose of Milan, De officiis, 1, 11, 38: OOSA 13, 44; PAX 12, 32; 1, 25, 120 : OOSA 13, 96; PAX 12, 61; 1, 30, 147: OOSA 13, 112; PAX 12, 71; 1, 30, 150: OOSA 13, 114; PAX 12, 72-73.

54 A. Fitzgerald, Almsgiving in the works of Saint Augustine, [in:] Signum pietatis. Festgabe für Cornelius Petrus Mayer zum 60 Geburtstag, Hrsg. A. Zumkeller, Würzburg 1989 , p. 445-459.

55 R. Finn, Almsgiving in the later Roman Empire, op. cit., p. 176-220.

56 Augustine of Hippo, Enarratio in Psalmum, 95, 15: NBA 27/1, a cura di T. Mariucci, V. Tarulli, Roma 19932, p. 354-358; PSP 40, tłum. J. Sulowski, red. E. Stanula, Warszawa 1986, p. 277-279; Sermo, 103, 5.6: NBA 30/2, a cura di L. Carrozzi, Roma 1983, p. 266.

57 Augustine of Hippo, Sermo, 50, 4: NBA 29, a cura di M. Pellegrino et al., Roma 1979, p. 948 . 
The studies regarding monasticism and voluntary poverty...

however they should be given to those who really needed help, they should come from one's own goods, and no one should put themselves into the state of poverty because of unwise support of others. One should not give away all the goods in alms only to find oneself a beggar a moment later. ${ }^{58}$

\section{The criticism of the wrong usage of material goods. Greed and usury}

In the ancient Christianity, condemnation of greed and usury was the manifestation of moral principles coming from the old and New Testament. ${ }^{9}$ The Church preachings that had evolved on the subject of usury did not accept the norms of the Roman legislation concerning taxes on loans (e.g. maximum interest rate). The oldest synods and canonical norms were unconditionally against the usury: the Synod of Elvira (circa 303 a.d.), the Synod of Arles (314 a.d.), canon fourteenth of the Council of Nicaea (325 a.d.), the Synod of Carthage (355 a.d.). The Church Fathers of the fourth and fifth centuries considered usury from the perspective of religion as well as social and moral perspectives. ${ }^{60}$

\subsection{The criticism of greed}

The desire to possess gold is deceptive as its worth is a concept agreed upon by people. ${ }^{61}$ For that reason, Ambrose condemned all

\footnotetext{
58 Augustine of Hippo, Epistola, 243, 12: NBA 23, a cura di L. Carrozzi, Roma 1974, p. 832; Epistola, 262, 5-6.8: NBA 23, 910.912.914.

59 R. Newhauser, The early history of greed. The sin of avarice in Early Medieval thought and literature, New York 2000, p. 1-21.

$60 \quad$ J. Majka, Stanowisko chrześcijaństwa wobec lichwy w starożytności i wczesnym średniowieczu, "Roczniki teologiczno-kanoniczne" 10 (1963) z. 2, p. 78-85.

${ }_{61}$ Ambrose of Milan, De Nabuthae, 13, 55: OOSA 6, 174 (Polish transl. PSP 35, 45); cf. Syr 31, 7.
} 
aspects of greed which were a form of idolatry and were in opposition with God's will to make goods common to all people. ${ }^{62}$ Ambrose also considered greed to be a social disorder as it destroyed the rich $^{63}$ and also the people around. ${ }^{64}$ The criticism of greed found justification in the biblical thesis according to which the world had been created for the whole human family. All people, be they rich or poor, were born and died with nothing of matter, not even clothes (Isa 5:8; Job 1:21; Acts 8:20). ${ }^{65}$ Material goods were for all people. Ambrose claimed that it went against the law of nature for the rich to hoard most of material goods depriving the poor of the possibility to use them. ${ }^{66}$ The rich themselves were not to experience happiness through growing rich, as the process of successive enrichment escalated greed. ${ }^{67}$ Paradoxically, coveters were not satisfied with income or heavy crops; they bemoaned about impending poverty to justify insatiable desire to possess. ${ }^{68}$ Acquisitiveness, in St. Ambrose's mind, was more often than not fueled by other coveters, i.e. greedy wives of the rich, in the Bible symbolized by Queen Jezebel. ${ }^{69}$ Greedy women were the source of expenses in their pursue of comfort and valuables. ${ }^{70}$ Greed was a disease, imprisonment and sin's servitude. Coveters would never be able to avoid death, even though through alms they would be able to profit in heaven

62 Ambrose of Milan, De Nabuthae, 3, 11: OOSA 6, 138 (Polish transl. PSP 35, 29); cf. V. R. Vasey, The social ideas in the works of. St. Ambrose, op. cit., p. 176-181.

63 Ambrose of Milan, De Nabuthae, 6, 29: OOSA 6, 152 (Polish transl. PSP 35, 35); cf. Koh 5, 11 .

64 Ambrose of Milan, De Nabuthae, 7, 35: OOSA 6, 156 (Polish transl. PSP 35, 37).

65 Ambrose of Milan, De Nabuthae, 1, 2: OOSA 6, 130.132; PSP 35, 26-27; 3, 11-12: OOSA 6, 138.140; PSP 35, 29-30; 13, 54: OOSA 6, 174; PSP 35, 45.

66 Ambrose of Milan, De Nabuthae, 1, 1: OOSA 6, 130 (Polish transl. PSP 35, 26).

67 Ambrose of Milan, De Nabuthae, 12, 52: OOSA 6, 170 (Polish transl. PSP 35, 44).

68 Ambrose of Milan, De Nabuthae, 6, 31: OOSA 6, 154 (Polish transl. PSP 35, 36).

69 Ambrose of Milan, De Nabuthae, 3, 13: OOSA 6, 140 (Polish transl. PSP 35, 43).

70 Ambrose of Milan, De Nabuthae, 5, 25-26: OOSA 6, 148.150 (Polish transl. PSP 35, 34); The criticism of women belonged to a certain literary topos, cp. Plutarch, $O \dot{z} a ̨ d z y$ bogactwa, 5-6: Plutarch, Moralia (wybór), tłum. Z. Abramowiczówna, Kraków 1977, p. 97100; Wergiliusz, Georgiki, II, 506: Wergiliusz, Bukoliki i Georgiki, tłum. Z. Abramowiczówna, Wrocław 1953, p. 88. 
100 The studies regarding monasticism and voluntary poverty...

and avoid the eternal death. Hence, Ambrose advised people to give away their goods. ${ }^{71}$ Augustine followed in the steps of Ambrose and condemned acquisitiveness, especially the urge to possess money. Greed, in St. Augustine's mind, was understood as acquisitiveness, rather than the lust to have honors, power or recognition. Greed was a random desire for goods, especially material ones, identified with gold, silver and money in general (ethymologically: latin avaritia, from aviditas auri meaning lust for gold, similarily the Greek filarguria, meaning the love of silver, literally the love of white metal, so therefore the love of silver coins i.e. denarius).$^{72}$ In consequence, greed concerned all the goods that could be paid for with money. ${ }^{73}$ According to the Doctor of Hippo, greed manifested itself through any profit that would be higher than the minimum needed to survive. He also condemned amassing money and rejected any positive aspects of hoarding goods. Ideally, goods should be owned in moderation. ${ }^{74}$

\subsection{The criticism of usury}

Ambrose of Milan, in his treatise Tobit (De Tobia), ${ }^{75}$ created between the years 385 and 389, heavily criticized the rich who practiced usury, which in the fourth century was a severe social plague. ${ }^{76}$ Due to usurers, insolvent debtors used to sell their own children

71 Ambrose of Milan, De Nabuthae, 6, 27-29: OOSA 6, 150.152; PSP 35, 34-35; 7, 3537: OOSA 6, 156.158; PSP 35, 37-38; 8, 38: OOSA 6, 158.160; PSP 35, 38-39; 13, 55-57: OOSA 6, 174.176; PSP 35, 45-47; 14, 58-60: OOSA 6, 178.180; PSP 35, 47-48.

72 More about IV-V cent. Christian attitudes towards money: J. Jundziłł, Ztoto i srebrojako pieniądz w literaturze patrystycznej okresu późnego Cesarstwa Rzymskiego, "Vox Patrum”12-13 (1987), p. 189-203.

73 Augustine of Hippo, De Genesi ad litteram, 11, 15.19-20: NBA 9/2, a cura di L. Carrozzi, Roma 1989, p. 580, 600.

74 J. Jundziłl, Pieniądz $w$ tacińskiej literaturze chrześcijańskiej okresu późnego cesarstwa, Warszawa 1984, p. 170 (Studia Antiquitatis Christianae, 3).

75 Ambrose of Milan, De Tobia, OOSA 6, 198-285, 80-121.

76 V. R. Vasey, The Social Ideas in the Works of. St. Ambrose, op. cit., p. 165-171; J. Jundziłł, Traktat Ambrożego o Tobiaszu, PSP 35, Warszawa 1986, p. 57-79. 
to slavers; ${ }^{77}$ sometimes usurers went as far as to hold the bodies of deceased debtors and threatened not to release them until the debt had been paid for. ${ }^{78}$ Ambrose condemned the wealth of usurers, as he perceived it as a renascent and invincible strength. The profit from money in constant turnover was against the nature and when the profit was that huge, it became criminal. Ambrose compared the profit to the yield of nature. ${ }^{79}$ As J. Jundzilł observed, the criticism of usury in Ambrose's was partially subjective, nevertheless it suited the Roman aristocrat, who treasured his land and employed traditional Aristotle reasoning about the unproductiveness of money. ${ }^{80}$ For the Bishop of Milan, the grounds for the criticism of usury were mainly religious; Ambrose opposed greed by reproving human weaknesses and such a controversial context was also set for the subject of money. From the religious point of view, money was not sufficient to give the man salvation, and greed was an obstacle to reach it. ${ }^{81}$ Practicing usury was dubbed by the Bishop of Milan as unnatural as it was based on tricky usage of money; on the other hand, Ambrose did not condemn loans, which was a form of help to the needy. ${ }^{82}$ Usury was forbidden by the Old Testament (Deut 23:19); and the laments about the harm done to the poor by usurers went as far as to King David; ${ }^{83}$ the desire to get rich was the very reason for Judas's betrayal and selling Christ to

77 Ambrose of Milan, De Tobia, 8, 29-31: OOSA 6, 224.226; PSP 35, 92-93.

78 Ambrose of Milan, De Tobia, 10, 36: OOSA 6, 230.232; PSP 35, 94.

79 Ambrose of Milan, De Tobia, 13, 43: OOSA 6, 238.240 (Polish transl. PSP 35, 9899); cf. Ecc1 3:2-3.

80 J. Jundziłł, Traktat Ambrożego o Tobiaszu, op. cit., p. 70, 77, while commenting on the topic emphasised that in the fourth century, the capital's interest rate was 1/100 a month, which gave $12 \%$ a year (top limit that became a norm in the Roman Empire), which was a rather high one. It was legally approved, although it was lower than in the times of the early Empire, when 36\% a year was demanded.

$81 \quad$ J. Jundziłł, Pieniądz $w$ tacińskiej literaturze chrześcijańskiej okresu późnego cesarstwa, op. cit., p. 150-160, more about greed in Ambrose's cf. footnote 25, 151.

82 Ambrose of Milan, De Tobia, 2, 7: OOSA 6, 202 (Polish transl. PSP 35, 83); cf. Sir 29:2; Ps 112:5; Deut 23:19.

83 Ambrose of Milan, De Tobia, 4, 12: OOSA 6, 208; PSP 35, 84; cf. Ps 55:10-12. 
102 The studies regarding monasticism and voluntary poverty...

the Sanhedrin. ${ }^{84}$ In the Gospel (Lk 6:32-36), Christ encouraged people to give loans to people who were not able to give the money back in order to let the usurers' profit thwart. ${ }^{85}$ The reasons for which St. Augustine from Hippo rejected usury were religious. He defined usury as the kind of loan were the amount lent was smaller than the amount paid back; what is more, expecting gifts or payment in kind in exchange for the loan was also considered usurious. For the Bishop, usury was always reprehensible, for the usurer made money without work, made profit out of profit, and these were defined as fraud and indecency that went against the Law of God as well as the human law; ${ }^{86}$ the usurer's practice harmed other people, and for the usurer himself his deeds were the source of growing greed that pulled him away from God. ${ }^{87}$

\section{The Pelagian criticism of wealth}

The heterodox Pelagians had different views upon Christian concept of possessing material goods. For their views, they were condemned not only at the synods of the African Church in 411, in 416 (two synods) and in 418, but also by the decisions of Pope Innocent I in 416 and Pope St. Zosimus (after $1^{\text {st }}$ May 418). ${ }^{88}$ On $9^{\text {th }}$ June 425 , the decrees were confirmed by Galla Placidia, who, on behalf of the minor Valentin III, issued a rescript against the Pelagians staying in the territories of the Gaelic diocese and instructed the authorities of

\footnotetext{
84 Ambrose of Milan, De Tobia, 4, 12: OOSA 6, 208 (Polish transl. PSP 35, 84-85); cf. Ps 109:2. 11.

85 Ambrose of Milan, De Tobia, 16, 54: OOSA 6, 252; PSP 35, 104-105.

86 Augustine of Hippo, Enarratio in Psalmum, 36, 3-5: NBA 25, 750-754.

87 J. Jundziłl, Pieniądz $w$ łacińskiej literaturze chrześcijańskiej, op. cit., p. 171-172, more on Augustinian definitions of usury footnote 71, 171.

88 K. Burczak, Biskupi afrykańscy wobec herezji pelagianizmu, "Vox Patrum" 22 (2002) t. $42-43$, p. $437-455$.
} 
the imperial administration to fight them down. ${ }^{89}$ Finally, in the year 431 (the conciliar letter of 22nd June 431) at the third Ecumenical council in Ephesus, the Pelagians were officially excluded from the Church..$^{90}$ According to the Pelagians, the man had unrestrained free will and an individual moral responsibility. The teachings of the monk Pelagius, doctrinally developed by Celestius, and even more significantly by Julian Bishop of Eclanum in Apulia, accentuated the impossibility of bringing divine grace and free will together. The teachings also accentuated the first man's mortality and the fact that unbaptized children would be saved. ${ }^{91}$ The Pelagians rejected the Augustinian interpretation of the birth-sin, epitomizing the first bad example, which did not destroy human nature and after the original sin of Adam and Eve, people still had free will. For Pelagius, exonerating the man was an undeserved gift from Christ, who saved humanity, which found redemption in His blood, proved in a sacrament of baptism. ${ }^{92}$ However, to receive full salvation, people need to desist from sin, hence the Pelagian recommendation of ascetic life and the urge to establish the Church for the ascetic-moral elite..$^{93}$

89 Mariusz Mercator, De Synodis habitis in causa Pelagianorum, XXI Synodus: PL 48, 369B.

90 J. D. Mansi, Sacrorum Conciliorum Nova et Amplissima Collectio, vol. 5, Paris 1901 (reprint wydania z Florencji 1759nn), 1338; cf. G. Bonner, Pelagius/Pelagianischer Streit, [in:] Theologische Realenzyklopädie, Hrsg. G. Müller, Bd. 26, ed. W. De Gruyter, BerlinNew York 1996, p. 178-185.

91 More on Pelagian theology and controversies: V. Grossi, La polemica pelagiana: avversari e amici di Agostino, [in:] Patrologia, vol. 3: Dal Concilio di Nicea (325) al. Concilio di Calcedonia (451). I Padri latini, a cura di A. di Berardino, Casale 1978, p. 437-465; J. P. Burns, The interpretation of Romans in the Pelagian controversy, "Augustinian Studies" 10 (1979), p. 43-54; A. Baron, Pelagiusz i jego dzieto, [in:] Pelagiusz, Komentarz do Listu św. Pawła do Rzymian, ŹMT 15, Kraków 1999, p. 12-167; H. Krabbendam, Sovereignty and responsibility. The Pelagian-Augustinian controversy in philosophical and global perspective, Bonn 2002; M. Lamberigts, Recent research into Pelagianism with particular emphasis on the role of Julian of Aeclanum, “Augustiniana” 52 (2002), p. 175-198.

92 M. Michalski, Nauka chrystologiczna Pelagiusza, "Collectanea Theologica" 17 (1936), p. 143-164, especially p. 155; E. Florkowski, Soteriologia Pelagiusza, Kraków 1949, p. 103-150.

93 A. Baron, Pelagiusz i jego dzieło, op. cit., p. 106-116. 
The studies regarding monasticism and voluntary poverty...

According to A. Solignac, condemning material goods was one of the most important claims of the Pelagian movement. Even if we do not find many observations about it in the texts of Pelagius, ${ }^{94}$ the condemnation was a part and parcel of his verbal teachings ${ }^{95}$ and in other Pelagians' treatises, such as Fastidius, Homelia de penitentibus and Epistula ad Pammachium et Oceanum de renuntiatione saeaculi, Pseudo-Sixtus Epistula "Honorificantiae" and in other anonymous works of Pelagians such as Epistula "Humanae" or Tractatus de Divitiis. ${ }^{96}$ On the basis of the preserved texts we may assume that Pelagius rejected greed, and connected the issue of possessing goods with charity. ${ }^{97}$ For the Pelagians, a significant role in the matter of wealth and poverty played an anonymous ${ }^{98}$ treatise De Divitiis. ${ }^{99}$ The author divided material goods into three categories: opulence (having more than enough), poverty (having less than necessary) and sufficiency (having only what is necessary). ${ }^{100}$ Having been inspired by the materially poor life of Jesus Christ, the Pelagian author of De divitiis rejected material wealth and suggested that the followers of Christ keep searching for material equality. ${ }^{101}$ The way people acquired and accumulated wealth

94 Pelagiusz, Epistola ad Marcellam, 8: “Tolerandae sunt [...] depositis oneribus et impedimentis atque compedibus, quibus saeculi huius divites attinentur, tu iam liberata et expedita”: PL 30, 54.

95 Augustine of Hippo, De gestis Pelagii, 35, 65: NBA 17/2, a cura di A. Trapè, I. Volpi, Roma 1981, p. 116, 118.

96 A. Solignac, Pélage et pélagianisme, [in:] AA. VV., Dictionnaire de spiritualité, 12/2, Paris 1984, p. 2923-2936, especially p. 2933.

97 A. Baron, Pelagiusz i jego dzieło, op. cit., p. 112-115.

98 G. Bonner, Augustine and modern Research on Pelagianism, St. Augustine Lecture 1971, Villanova 1972, p. 7-8, suggested that the author of the Pelagian treatise De Divitiis is probably a so-called Anonyme sicilien.

99 Anonimus, De Divitiis, [in:] Briefe, Abhandlungen und Predigten, Hrsg. C. P. Caspari, Christiania 1890, p. 25-67; reprinted in PLS 1, p. 1380-1418; more on the subject: A. Kessler, Reichtumskritik und Pelagianismus. Die pelagianische Diatribe "De divitiis", Paradosis 43, Freiburg (Schweiz) 1999; S. Toscano, Tolle divitem. Etica, società e potere del "De divitiis", (Collana: Testi e studi di storia antica), Edizioni del Prisma, Catania 2006.

100 De Divitiis, 5, 1: PLS 1, 1383.

101 De Divitiis, 6, 3: PLS 1, 1386-1387. 
was, according to the author of De divitiis, the result of social inequalities and exploitation of the poor by the rich. ${ }^{102}$ Assuming the basic Pelagians principles, the man could earn salvation through practicing asceticism The author of De Divitiis, interpreted chosen New Testamental texts paying special attention to the rejection of material wealth (Mt 8:20; 19:21; Lk 14:33; 1 Cor 7:7; 11:21) and put forward a final conclusion that Christians should reject all material goods, as this was a spiritually proper solution and the only one in accordance with the Gospel. ${ }^{103}$ Augustine of Hippo provided an answer to the Pelagian theses in the Letter 157; it was addressed to Hilary, Bishop of Syracuse. It was in Syracuse that a large number of Pelagians were active, and the author of De Divitiis was probably among them. While interpreting Lk 18:25, the Bishop of Hippo declared that both Christian rejection of wealth as well as making use of wealth was a gift of God's grace - though the usage should be fair, good and charitable - to prevent people from priding over one's own deeds and make them acknowledge God's grace as fundamental in the act of awaiting salvation. ${ }^{104}$ Augustine also reminded that in the texts of St. Paul, the reader would mainly encounter recommendations about how to use the wealth properly (1 Tim 6:1719),${ }^{105}$ whereas both Christ and St. Paul - who is a teacher of the same doctrine of Christ - never command Christians to renounce material goods, but order them to make a proper use of wealth and, above all, never submit to pride. ${ }^{106}$ Therefore, in the tangle of values,

102 De Divitiis, 7, 5: PLS 1, 1388; 8, 1: PLS 1, 1388.

103 De Divitiis, 9-10: PLS 1, 1390-1397.

104 Augustine of Hippo, Epistola, 157, 4, 29: NBA 22, 620.622.

$1051 \mathrm{Tm}$ 6:17-19: "As for those who in the present age are rich, command them not to be haughty, or to set their hopes on the uncertainty of riches, but rather on God who richly provides us with everything for our enjoyment. They are to do good, to be rich in good works, generous, and ready to share, thus storing up for themselves the treasure of a good foundation for the future, so that they may take hold of the life that really is life." Bible, NT, http://www.devotions.net/bible/00new.htm.

106 Augustine of Hippo, Epistola, 157, 4, 26-27: NBA 22, 618.620. 
The studies regarding monasticism and voluntary poverty...

a Christian should always give priority to God; ${ }^{107}$ a Christian may possess material goods that were obtained honestly, and should manage them in a morally fair and honest way. ${ }^{108}$ Goods should never be amassed inequitably; ${ }^{109}$ any unnecessary ones should be eschewed, whereas any superfluous goods should be shared with the needy, ${ }^{110}$ for the Heaven will also be for the wealthy who fear God. ${ }^{111}$

\section{The monastic criticism of wealth}

What nowadays exists in the Catholic Church as the vow of poverty, in early Christianity used to function as a number of practices, which not necessarily boiled down to a single monastic vow.

The official introduction of the three vows typical in western Christianity - obedience, chastity and voluntary poverty - did not take place until 1198 in the Rule of the Holy trinity Monastery (the Trinitarians). ${ }^{112}$ The first Christian monks of the Western Church ( $4^{\text {th }}$ century) and earlier monks of the Eastern Church ( $3^{\text {rd }}$ and $4^{\text {th }}$ centuries) alike, never separated the virtue of poverty from other virtues and practices of the monastic life, such as separation from the earthly life, renunciation of the family, obedience to the

107 Augustine of Hippo, Epistola, 157, 4, 33: NBA 22, 626; cp. 1 Tm 6:17; 1 Cor 7:30-31.

108 Augustine of Hippo, Epistola, 157, 4, 32-33: NBA 22, 624.626.

109 Augustine of Hippo, Epistola, 157, 4, 37: NBA 22, 630; cf. Lk 16:9.

110 Augustine of Hippo, Epistola, 157, 4, 34: NBA 22, 626.628.

111 Augustine of Hippo, Epistola, 157, 4, 37: NBA 22, 630.

112 Regula sancti Johannes de Matha ab Innocentio papa III aprobata, 1, 1, "Fratres domus Sancte Trinitatis sub obedientia prelati domus suae, qui minister vocabitur, in castitate et sine proprio vivant," Regola e Costituzioni dei Frati dell'Ordine della SS.ma Trinità, Roma 1986, 10; more on the slow formation of the concept of the three monastic vows: M. J. Sedano Sierra, Voti religiosi, 1: Storia, [in:] Dizionario teologio della vita consacrata, a cura di A. A. Rodríguez, J. M. Casas, Milano 1994, p. 1923-1936; J. Gribomont, Voto. I. In Oriente, a cura di G. Rocca, Dizionario degli Istituti di Perfezione [below-quoted as DIP], vol. 10, Roma 2003, p. 550-553; G. Rocca, Voto. II. In Occidente: visione storicogiuridica generale del voto solenne e del voto semplice, [in:] DIP X, a cura di G. Rocca, p. 553-564. 
monastic superior, prayers, fasting and many others that comprised the monastic conuersatio style. ${ }^{13}$

In the thirties of the $4^{\text {th }}$ century, Life of St. Antony ${ }^{114}$ was rendered into Latin, which introduced to the western monasticism a model example of a monk who renounced the inherited ${ }^{115}$ earthly goods, commenced a monastic life and supported himself and the needy with the work of his own hands. ${ }^{116}$ However, with the propagation of the eremite model of monasticism in the Western Church, popularized by Anthony the Hermit, St. Jerome of Stridon in Dalmacia started his campaign against money and possession of material goods. ${ }^{117}$ Thereby, a polemic against greed started among the western monks, resulting in a creation of an exemplar cenobite praised by ascetic writers over yielding daily earnings to monastic superiors, who in return - and without being asked to - provided him with the strictly necessary minimum of goods that was supposed to make the monk happy. ${ }^{118}$ Augustine of Hippo introduced western monks to an ascetic rule which prevented them from owning things and from being a burden to others, ${ }^{119}$ and later denied them any form of ownership ${ }^{120}$ pointing out the ideal of the community of thoughts and feelings in the early Jerusalem community. ${ }^{121}$ Rufinus of Aquileia (Concordia), upon rendering the monastic works of Basil the Great The Asceticon (latin: Instituta monachorum) and the Basilian Rule, wanted the western monks to acknow-

113 A. De Vogüé, Povertà, III: In Occidente. Monachesimo e vita canonicale dalle origini al sec. XI, [in:] DIP, vol. 7, a cura di G. Rocca, Roma 1983, p. 261.

114 Athanasius of Alexandria, Vita s. Antonii: PG 26, 835-976.

115 Athanasius of Alexandria, Vita s. Antonii 1-3: PG 26, 839-845; ŹM 35, 78-80.

116 Athanasius of Alexandria, Vita s. Antonii 3: PG 26, 844-845 (Polish transl. ŹM 35, 80).

117 Hieronymus, Epistola 14, 6: PL 22 351; Epistola 125, 20: PL 22, 1085; more on the gradual renunciation of material goods and negative attitudes towards possessing goods by ascetics and western monks: R. Newhauser, The early history of greed, op. cit., p. 22-95.

118 A. De Vogüé, Povertà, III: In Occidente..., op. cit., p. 262.

119 Augustine of Hippo, De moribus Ecclesiae catholicae 1, 31, 67: NBA 13/1, 98.

120 Augustine of Hippo, Regula ad servos dei 1, 3: NBA 7/2, Roma 2001, 30.

121 Augustine of Hippo, Regula ad servos dei 1, 2: NBA 7/2, 30; cf. Acts 4:32-35. 
108 The studies regarding monasticism and voluntary poverty...

ledge the ideal of self-renunciation and renunciation of passions and possessions. ${ }^{122}$ Also, he pointed out towards the ideal of communal living, collective property and its distribution within the monastic community in accordance with the principle that everyone receives according to one's needs, ${ }^{123}$ as well as towards the ideal of renouncing goods that are superfluous, ${ }^{124}$ the ideal of strict material asceticism (latin: continentia) according to which one should confine needs only to indispensable ones, such as food and clothes; ${ }^{125}$ the duty of work to earn one's living ${ }^{126}$ and the prohibition to individually support the poor in the form of alms by a member of the monastic community. ${ }^{127}$

Similar monastic rules regarding poverty in the community of St. Martin in Marmoutier may be noticed in the works of Sulpicius Severus - no private possessions, ${ }^{128}$ no work for profit, relying on financial generosity. ${ }^{129} \mathrm{~A}$. de Vogüé considered the last entry quite interesting due to the fact that Sulpician Dialogues were an individualitic reportage on the life of Egiptian monks, the poverty of which was not mentioned nor commented on by Sulpicius. ${ }^{130}$ Likewise, the translations of the Pachomian ascetic writings by Hieronim highlighted monks' contempt for material goods ${ }^{131}$ and their renuncia-

\footnotetext{
122 Basil the Great, Regulae fusius 8-9: PG 31, 933-944.

123 Basil the Great, Regulae fusius 29-30: PG 31, 989-993; ŹM 6, 129-131; Regulae brevis 92: PG 31, 1145.1148.

124 Basil the Great, Regulae brevis 129: PG 31, 1169; ŹM 6, 306; 187: PG 31, 1207; ŹM 6, 345-346; cp. Mt 10:10; Lk 10:4.

125 Basil the Great, Regulae fusius 9: PG 31, 941-944; ŹM 6, 86-89; Regulae brevis 126: PG 31, 1167; ŹM 6, 304; 134: PG 31, 1171; ŹM 6, 308.309.

126 Basil the Great, Regulae fusius 37: PG 31, 1009-1016; ŹM 6, 240-241; Regulae brevis 61: PG 31, 1123; ŹM 6, 257-258.

127 Basil the Great, Regulae brevis 89: PG 31, 1143; ŹM 6, 278-279; 100: PG 31, 1151; ŹM 6, 286-287.

128 Sulpicius Severus, De Vita Beati Martini 10: PL 20, 166B-166D.

129 Sulpicius Severus, Dialogi 3, 14: PL 20, 219C-220C.

130 A. de Vogüé, Povertà, III: In Occidente..., op. cit., p. 264.

131 Pachomiusz (Latin translation by Hieronymus of Stridon), Regula patris nosti Pachomii hominis dei 49: PL 23, 70A-70B.
} 
tion of private property. ${ }^{132}$ In the original Lerins Rule of the Four Fathers, renunciation of material goods applied especially to the rich in the postulant world ${ }^{133}$ and the monks from other orders that wanted to join the monastic obedience of Saint Honoratus of Lerins. ${ }^{134}$ Yet, in the Second Rule of the Fathers, which was applicable in Lerins since $427,{ }^{135}$ renunciation of material goods was considered obligatory to all monks of Lerins. It was supposed to constitute the basis of communal living and reflect communal love. ${ }^{136}$ Also, the norms according to John Cassian instructed the entering monks to get rid of all their money and worldly accessories, as well as don a unified monk's habit - as a symbol of their radical renunciation of worldliness - to become a Christ's follower among other poor monks. ${ }^{137}$ Christ and His humiliation upon the incarnation remained a paragon of monastic poverty; therefore, Cassian made a connection between Christ's poverty (Latin: paupertas Christi) and his humility, humbleness and insignificance (Latin: humilitas Christi). ${ }^{138}$

As A. de Vogüé observed, in the Western Church of the $5^{\text {th }}$ century, the virtues of poverty and humility were inseperable in the promoted model of a monk, just as they were inseparable in their

132 Pachomiusz (Latin translation by Hieronymus of Stridon), Regula patris nosti Pachomii hominis dei 98: PL 23, 75B; ŹM 11, 148; 106: PL 23, 75D; ŹM 11, 149; 113: PL 23, 76B; ŹM 11, 150.

133 Regula sanctorum Serapionis, Macarii, Paphnutii et alterius Macarii 2, 29-35: PL 103, 438A.

134 Regula sanctorum Serapionis, Macarii, Paphnutii et alterius Macarii 4, 11-12: PL 103, 440A; ŹM 3, 48.

135 J. Piłat, Wczesne reguły monastyczne z Galii. Wstęp, ŹM 3, suggested that just after the death of St. Honorius (427), and a change in the monastic superior in the Lerins monastry (St. Maxime was Honorius's successor), a change of the rule probably happened and new instructions were given to Lerins monks, called the Second Rule of the Fathers (alia partum regula ad monachos).

136 Alia partum regula ad monachos 5-6: PL 103, 442D-444A.

137 J. Cassian, De Coenobiorum Institutis 4, 3-6: PL 49, 155A-160A; 4, 13-14: PL 49, 167A-170A; 4, 19: PL 49, 178B-180A.

138 J. Cassian, De Coenobiorum Institutis 4, 5: PL 49, 159A; 4, 37: PL 49, 197C-198A; 10, 19: PL 49, 384C-385C. 
110 The studies regarding monasticism and voluntary poverty...

paragon, Jesus Christ. What the creators of monastic rules had in mind, were two different forms of the same humiliation. The first form would remain on the level of external renunciation (renunciation of material goods), whereas the second would be an inner, spiritual self-renunciation (the practice of humility, insignificance and obedience towards one's superior). Therefore, the monastic denudation of goods (Latin: nuditas) is the other term for monastic poverty (Latin: paupertas), which goes before humility and also generates one (Latin: humilitas). What was supposed to constitute a certain spiritual development at the beginning of the $6^{\text {th }}$ century, became a legal requirement. In the monastic rules of St. Caesar of Arles, renunciation of goods was imposed on postulants as a form of legal obligation towards the Church, which was to be signed autographically. ${ }^{139}$

\section{Conclusion}

In the teachings of the Church Fathers and Christian writers of the western Church of the $4^{\text {th }}$ and $5^{\text {th }}$ centuries, two general attitudes towards the concept of possessions, wealth and poverty may be distinguished: the realistic and the pessimistic one. The common streak in them was the belief that goods are common as they have a common Creator and people are only temporary users of the goods. In the scope of the realistic approach, for the community of Christians, Fathers embraced a model of decent acquiring, possessing and using of the goods. Possessing itself was understood as decent; it was advised that alms were given from the surplus and superfluous goods. All Christians were encouraged to eschew greed and usury.

In the scope of the pessimistic approach, the ideal of ascetic approach towards possessions was encouraged. Material goods,

139 A. de Vogüé, Povertà, III: In Occidente..., op. cit., p. 266-267. 
though created by God, remained a source of continual temptation and vices, especially greed and idolatry. Therefore, monasticism recommended an ascetic attitude towards earthly goods. We may distinguish between two tendencies when it comes to the issue of possessing goods: the anchoritic and cenobitic. The Anchorites followed the example of St. Anthony the Hermit, for whom possessing was legitimate and decent, goods were home-made, and what was superfluous was to be given away in the form of alms. A significantly more widespread model in the Western Church throughout the $4^{\text {th }}$ to the $5^{\text {th }}$ century, was cenobitic monasticism. For the Cenobites, personal possession was illegitimate and the monastic goods were owned by the community. An ascetic contempt should be held towards all material goods and the usage of the goods should be reduced to minimum. According to the rules of St. Pachomius, adjusted to the western cenobites by the following monastic founders, material goods remained an exclusive property of the community; an individual cenobite did not have anything in his possession and a monastic superior decided upon meeting material needs of his monk.

There also existed a heterodox version of the pessimistic approach towards the wealth, propagated in the $4^{\text {th }}$ and $5^{\text {th }}$ centuries by the Pelagian movement. In their opinion, all Christians should renounce material goods and live in poverty - the only way expected from a Christian. The most characteristic phenomenon could be observed in the $4^{\text {th }}$ and $5^{\text {th }}$ centuries, when the optimistic image of material goods literally disappeared. Therefore, in the texts of the Fathers of the Western Church, we are not likely to come across the opinion which would admit wealth to be the means towards sanctification and Divine Protection in exchange for pious devotion (as it could be observed in the third century e.g. in Clement of Alexandria). 


\section{The concept of voluntary poverty in the monastic writings of St. Augustine, the bishop of Hippo*}

What is known nowadays in the contemporary spiritual theology as the doctrine of voluntary or ascetic poverty, in the first centuries of Christianity was simply a number of ascetic practices. It is difficult to describe these practices in an organized way and it is equally difficult to deduce a homogenous vision of a single ascetic practice, not to mention the methodological difficulty implicated in reading ancient texts. Classical authors provided very fragmentary descriptions of ascetic behaviours and they presented their views in a range of documents that were created in various theological contexts. When one is faced with such fragmentary records, one is better off to focus on one ascetic practice, in this case on monastic poverty, and to trace the progress of views of a given author chronologically, while at the same time providing a context for the emergence of original thoughts. ${ }^{1}$

In the primitive Christian Coenobitism, which emerged in the Egyptian desert at the beginning of the $4^{\text {th }}$ century (St. Pachomius

\footnotetext{
* This article was originally published under the title: Koncepcja dobrowolnego ubóstwa w pismach monastycznych św. Augustyna, "Vox Patrum" 33 (2013) t. 60, p. 165-182.

1 A. De Vogüé, Povertà, III: In Occidente. Monachesimo e vita canonicale dalle origini al sec. XI, [in:] Dizionario degli Istituti di Perfezione [further quoted as: DIP], vol. 7, a cura di G. Rocca, Roma 1983, p. 261.
} 
The studies regarding monasticism and voluntary poverty...

of Thebaid), evangelical counsels were not yet formalised and understood as vows of obedience, chastity, and poverty. The first Christian Coenobites who practised the virtue of poverty never separated it from other virtues and practices of monastic life. ${ }^{2}$ Similarly, the first western monks, such as: Eusebius of Vercelli, ${ }^{3}$ Martin of Tours, ${ }^{4}$ or Paulinus of Nola, ${ }^{5}$ after their ascetic conversion, tried to lead their lives according to the evangelical model. In their writings, as well as in the first hagiographies devoted to them, there are just fragmentary notes on voluntary poverty, which is a manifestation of a solitary life, of leaving the life behind, of the renunciation of property, and of donating your goods to the community of faith. ${ }^{6}$ However, these western monks never developed a cohesive ascetic programme regarding (the issue of) monastic poverty in their writings.

2 The formalisation took place in the Western Church only in the Rule of the Most Holy Trinity in 1189. Regula sancti Johannes de Matha ab Innocentio papa III aprobata 1, 1: "Fratres domus Sancte Trinitatis sub obedientia prelati domus suae, qui minister vocabitur, in castitate et sine proprio vivant": Regola e Costituzioni dei Frati dell'Ordine della SS.ma Trinità, Roma 1986, 10; about creating of the idea of counsels cf. M. J. Sedano Sierra, Voti religiosi, vol. 1: Storia, [in:] Dizionario teologio della vita consacrata, a cura di A. A. Rodríguez, J. M. Casas, Milano 1994, p. 1923-1936; J. Gribomont, Voto, I: In Oriente, DIP X, a cura di G. Rocca, Roma 2003, p. 550-553; G. Rocca, Voto. II: In Occidente. Visione storico-giuridica generale del voto solenne e del voto semplice, [in:] DIP X, a cura di G. Rocca, p. 553-564.

3 L. Dattrino, San Eusebio di Vercelli. Vescovo "martire"? Vescovo "monaco"?, "Augustinianum" 24 (1984), p. 167-187; E. Dal Covolo, Eusebio di Vercelli, Ambrogio di Milano, Massimo di Torino. Il vescovo e la sua città fra IV e il V secolo, "Archivio teologico torinese" 4/2 (1998), p. 69-84; D. A. Washburn, Tormenting the tormentors. A reinterpretation of Eusebius of Vercelli's letter from Scythopolis, "Church History" 78 (2009), p. 731-755.

4 P. J. Nowak, Św. Marcin z Tours - aktualny model mitości, “Vox Patrum” 49 (2006), p. 483-493.

5 D. Kasprzak, Il pensiero sociale di Paolino da Nola, "Studia Laurentiana" 2 (2002) Suplement 1, p. 77-82, 156, 172-185.

6 Cf. Ambrose of Milan, Epistula 63,71-82; Sulpicjusz Sewer, Vita Sancti Martini 2,8; 3,1; 10,2; Sulpicjusz Sewer, Epistula 3,21; Sulpicjusz Sewer, Dialogus 2,5,10; 3,14,6; Paulinus of Nola, Carmina 16,245-250; 21,495-534; 24,546-550.901-918; Paulinus of Nola, Epistulae 1,1.7; 5,4-5; 11,12-14; 13,17.22-23; 16,8; 23,34-35; 24,4-8.20; 25,2; 29,12; 35,1. 
In this article, I wish to provide an outline of St. Augustine's doctrine of voluntary poverty and present it diachronically and contextually. First, I discuss the early Augustinian thought on ascetic poverty, and then I move on to the more mature reflections of the bishop of Hippo on that subject.

\section{The early reflections of St. Augustine on monasticism and voluntary poverty}

Augustine was not the first Christian author who pondered on the issue of ascetic poverty. He was, nevertheless, the first theologian in the Western Church who formulated a fairly cohesive and original doctrine of monastic poverty. St Augustine's ascetic thought, including his reflections on monastic poverty, influenced greatly the development of subsequent monastic rules in the Western Church. For instance, it had an impact on the monastic rule of Ceasar of Arles, ${ }^{7}$ the Rule of Eugippius, ${ }^{8}$ and the Rule of St. Benedict, ${ }^{9}$ and

7 C. Lambot, La Règle de saint Augustin et saint Césaire, "Revue Bénédictine" 41 (1929), p. 333-341; A. de Vogüé, La Règle de Césaire d’Arles pour les moines. Un résumé de sa Règle pour les moniales, "Révue d'histoire de la spiritualité" 47 (1971), p. 369-406.

8 A. de Vogüé, La Règle de saint Benoit, vol. 1, Paris 1972, SCh 181, 33-39.

9 C. Lambot, L’influence de saint Augustin sur la Règle de saint Benoît, "Revue liturgique et monastique” 14 (1929), p. 320-330; E. Manning, La législation monastique de Saint Augustin et la Regula Monachorum, “Augustiniana” 16 (1966), p. 317-329, 475-480; A. De Vogüé, Sant’Agostino e San Benedetto, “Ora et labora” 50 (1995), p. 97-107; A. De Vogüé, Saint Augustin et s. Benoît, [in:] Etudes sur la Règle de S. Benoît, Nouveau Recueil, Bégrolles-en-Mauges 1996, p. 33-46 (Spiritualité Monastique, 34); J. R. Fortin, Saint Augustine's letter 211 in The Rule of the Master and The Rule of Saint Benedict, "Journal of Early Christian Studies” 14/2 (2006), p. 225-234. Cf. Ambrose of Milan, Epistula 63,7182; Sulpicius Severus, Vita Sancti Martini 2,8; 3,1; 10,2; Sulpicius Severus, Epistula 3,21; Sulpicius Severus, Dialogus 2,5,10; 3,14,6; Paulinus of Nola, Carmina 16,245-250; 21,495534; 24,546-550.901-918; Paulinus of Nola, Epistulae 1,1.7; 5,4-5; 11,12-14; 13,17.22-23; 16,8; 23,34-35; 24,4-8.20; 25,2; 29,12; 35,1; C. Lambot, La Règle de saint Augustin et saint Césaire, "Revue Bénédictine” 41 (1929), p. 333-341; A. de Vogüé, La Règle de Césaire d'Arles pour les moines. Un résumé de sa Règle pour les moniales, "Révue d'Histoire de la Spiritualité" 47 (1971), p. 369-406; A. de Vogüé, La Règle de saint Benoit, vol. 1, Paris 1972, SCh 181, 33-39; C. Lambot, L'influence de saint Augustin sur la Règle de saint Benoît, 
116 The studies regarding monasticism and voluntary poverty...

in the Middle Ages, the so-called Rule of St. Augustine was adopted by various orders (Canons, Augustinians, Canons Regular, Premonstratensias, Servites, Dominicans). ${ }^{10}$

As Adalbert De Vogüé noted, first translations of The Life of St. Anthony ${ }_{11}^{11}$ made from Greek into Latin in the thirties of the $4^{\text {th }}$ century, offered western monasticism a model of a monk. ${ }^{12}$ According to a hagiographical model provided by Athanasius of Alexandria, an ideal monk - St. Anthony the Hermit, renounced his earthly goods (that he inherited from his parents), ${ }^{13}$ and began a monastic life. He started working which allowed him to earn his living and to donate his earnings to the poor. ${ }^{14}$ St. Anthony renounced his private property after having read and reflected on the following texts: Mt 4:20; 19:27 Acts 4:35-37 and Mt 19:21 and Mt 6:34. As a result of his readings, he distributed his property among the poor, and began earning his own living and giving alms. ${ }^{15}$

However, the eremitic model of monastic poverty, represented by St. Anthony, although admired by many, did not become popular in the West, because it was opposed by the followers of Coenobitism. Both Jerome and Augustine, as well as Basil the Great on the East, propagated the superiority of the coenobitic life over the eremitic life. The ascetic polemic of the supporters of Coenobitism who claimed its superiority over Eremitism was accompanied by

\footnotetext{
"Revue Liturgique et Monastique"14 (1929), p. 320-330; E. Manning, La législation monastique de Saint Augustin et la Regula Monachorum, "Augustiniana” 16 (1966), p. 317-329, 475-480; A. De Vogüé, Sant'Agostino e San Benedetto, “Ora et Labora” 50 (1995), p. 97-107.

10 A. Solignac, Pauvreté chrétienne, II: Pères de l'Eglise et moines des origines, 2: En Occident, [in:] Dictionnaire de Spiritualité Ascétique et Mystique [further quoted as: DSp] 12, Paris 1984, p. 643.

${ }_{11}$ Athanasius of Alexandria, Vita s. Antonii: PG 26, 835-976 (Polish transl.: Żywot św. Antoniego: Źródła Monastyczne 35 [further quoted as ŹrMon 35], joint translation, Kraków 2005, p. 77-152).

12 A. De Vogüé, Povertà, op. cit., p. 261.

13 Athanasius of Alexandria, Vita s. Antonii, 1-3: PG 26, 839-845; ŹrMon 35, 78-80.

14 Athanasius of Alexandria, Vita s. Antonii, 3: PG 26, 844-845 (Polish transl. ŹrMon $35,80)$.

15 A. De Vogüé, Povertà, op. cit., p. 262.
} 
a polemic of Western monks against the vice of greed. ${ }^{16}$ In the West, the campaign against money and material goods was launched by St. Jerome of Stridon. ${ }^{17}$ It was then taken up by other ascetic writers. Eventually, in the first half of the $4^{\text {th }}$ century, the ascetic model of a Cenobite was promoted in the Western Church. The exemplar Coenobite was supposed to give his superiors his daily wages and in return, without asking for it, received an absolute minimum of goods that was supposed to satisfy him. ${ }^{18}$ These coenobitic ideals were also promoted in the monastic writings of St. Augustine who developed his concept of voluntary poverty in his consecutive works.

While living in Milan in a rented villa hosted his compatriot, who like him came from North Africa, Augustine had Pontician - the imperial guard (and most probably a member of a secret Roman imperial service - Latin "agentes in rebus") - staying with him. Pontician was the first person to tell Augustine about Alipius and Anthony the Hermit, ${ }^{19}$ about monastic communities of Egypt, Milan and Trier. ${ }^{20}$ This took place shortly before Augustine converted to Christianity

16 R. Newhauser, The early history of greed. The sin of avarice in Early Medieval thought and literature, Cambridge University Press, New York 2000, p. 22-95.

17 Jerome, Epistola, 14, 6: PL 22, 351; Epistola, 125, 20: PL 22, 1085.

18 A. De Vogüé, Povertà, op. cit., k. 262.

19 Augustine of Hippo, Confessionum, 8,6: NBA 1, eds. M. Pellegrino, C. Carena, Città Nuova Editrice, Roma 19936, 232 (a conversation arose ["suggested by his account] on Antony the Egyptian monk: whose name was in high reputation among Thy servants, though to that hour unknown to us. Which when he discovered, he dwelt the more upon that subject, informing and wondering at our ignorance of one so eminent." http://www.gutenberg. org/cache/epub/3296/pg3296.html).

20 Augustine of Hippo, Confessionum, 8,6: NBA 1, 232: "Thence his discourse turned to the flocks in the monasteries, and their holy ways, a sweet-smelling savour unto Thee, and the fruitful deserts of the wilderness, whereof we knew nothing. And there was a monastery at Milan, full of good brethren, without the city walls, under the fostering care of Ambrose, and we knew it not [...] He told us then how one afternoon at Triers, when the Emperor was taken up with the Circensian games, he and three others, his companions, went out to walk in gardens near the city walls, and there as they happened to walk in pairs, one went apart with him, and the other two wandered by themselves; and these, in their wanderings, lighted upon a certain cottage, inhabited by certain of Thy servants, poor in spirit, of whom is the kingdom of heaven, and there they found a little book containing the life of Antony." http://www.gutenberg.org/cache/epub/3296/pg3296.html. 
118 The studies regarding monasticism and voluntary poverty...

so the conversation with Pontician preceded Augustine's decision to devote himself to God.

Augustine claimed that in this way God "delivered me out of the bonds of desire, wherewith I was bound most straitly to carnal concupiscence, and out of the drudgery of worldly things." ${ }^{21}$ Augustine reacted to the stories about primitive monasticism with amazement and astonishment. ${ }^{22}$ However, apart from expressing his admiration for heroic characters of first monks - especially for St. Anthony the Hermit who was slowly becoming an exemplar of new sanctity - Augustine neither took up the eremitic form of monasticism nor did he particularly promote it. The case of Anthony the Hermit perhaps evoked in Augustine some kind of nostalgia for the times of early Christianity and it directed his attention to the ideal of the first Jerusalem community, but we find in Augustine's writings neither eremitic influences nor references to Anthony the Hermit's way of life. As Domingo Sanchis noticed, Augustine discovered the Church in its community dimension, but the Holy Spirit led him to the solitude of the desert. ${ }^{23}$ These were two different types of monasticism, but still in the same Church.

After having received baptism in Easter of 387, Augustine visited the monastery outside Milan, which he had already known from Pontician's stories, and the life of monks there made a great

21 Augustine of Hippo, Confessionum, 8,6: "de vinculo quidem desiderii concubitus, quo artissimo tenebar, et saeculiarum negotiorum servitute quemadmodum me exemeris": NBA 1, 230 (Polish transl. Z. Kubiak, 1997, p. 170). http://www.gutenberg.org/cache/ epub/3296/pg3296.html.

22 Augustine of Hippo, Confessionum, 8,6: NBA 1, 232 (English transl.: "But we stood amazed, hearing Thy wonderful works most fully attested, in times so recent, and almost in our own, wrought in the true Faith and Church Catholic. We all wondered; we, that they were so great, and he, that they had not reached us." http://www.gutenberg.org/cache/ epub/3296/pg3296.html).

23 D. Sanchis, Pauvreté monastique et charitè fraternelle chez saint Augustin. Le commentaire augustinien de Actes 4,32-35 entre 393 et 403, "Studia Monastica" 4/1 (1962), p. 7-33. 
impression on him/greatly impressed him..$^{24}$ The rules of the Milan monastery probably mirrored the concept of monasticism represented by Ambrose of Milan, who was in charge of the place. These norms undoubtedly influenced the formation of Augustine's concept of monastic life. ${ }^{25} \mathrm{He}$ then spent the whole year of 388 in Rome, due to the invasion of Italy by Magnus Maximus (who was then defeated in 388 by Theodosius I) and due to the death of his mother St. Monica. While in Rome, he became well familiar with Roman monasticism which was promoted in the seventies of the $4^{\text {th }}$ century by St. Jerome. A group of male and female ascetics lived under the supervision of, correspondingly, a male or female superior who surpassed their subjects intellectually. Members of such congregations were very community-oriented, practised strict asceticism and followed the rules of mutual love, respect, and unity. ${ }^{26}$ Thus, Roman monasticism developed by St. Jerome influenced Augustine and his concept of monasticism. As we can see in the book written at that time and entitled On the Morals of the Catholic Church and on the Morals of the Manichaeans, the Christian ascetic was for Augustine the exemplar of a wise man. ${ }^{27}$

On the Morals of the Catholic Church, written in 388, contained Augustine's first comments on voluntary poverty. Talking about first monks, Augustine expressed his admiration for Anchorites, but at the same time, distanced himself from them, ${ }^{28}$ whereas he extolled

24 Augustine of Hippo, De moribus Ecclesiae catholicae et de moribus manichaeorum, 1,70: NBA 13/1, a cura di A. Pieretti, Città Nuova Editrice, Roma 1997, p. 102; Polish transl. ŹrMon 27. Św. Augustyn, Pisma monastyczne, only partial Polish transl. (only extracts I, 64-73) P. Nehring, wyd. benedyktynów Tyniec, Kraków 2007³ , p. 180.

25 A. Zumkeller, Das Mönchtum des heiligen Augustinus, Augustinus-Verlag, Würzburg $1968^{2}$, p. $51-52$.

26 Augustine of Hippo, De moribus Ecclesiae catholicae, 1,70-73: NBA 13,1, 102-106; ŹrMon 27, 180-184.

27 P. Nehring, Wstęp, ŹrMon 27, 43-44.

28 Augustine of Hippo, De moribus Ecclesiae catholicae, 1,31,66: NBA 13/1, 96.98; ŹrMon 27, 176. 
The studies regarding monasticism and voluntary poverty...

openly Coenobites. ${ }^{29}$ He especially emphasized Coenobites' community lifestyle and the unity of faith and morals. ${ }^{30}$ The collective character of the coenobitic life, which was based on the love of God and one's neighbour and which strengthened a unity of a community, friendship ties and an ascetic way of life, counterbalanced, in Augustine's opinion, the Manichean vision of community, which rejected certain forms of Christian asceticism. ${ }^{31}$ In the context of community, Augustine referred to coenobitic poverty for the first time when he stated that:

No one possesses anything of his own; no one is a burden to another. They work with their hands in such occupations as may feed their bodies without distracting their minds from God. The product of their toil they give to the decans or tithesmen, so called from being set over the tithes so that no one is occupied with the care of his body, either in food or clothes, or in anything else required for daily use or for the common ailments. ${ }^{32}$

The rule of the Egyptian Coenobites saying that no one should possess anything of his own or be a burden to another, which Augustine praised and somehow introduced to Western

29 Augustine of Hippo, De moribus Ecclesiae catholicae, 1,31,67: NBA 13/1, 98.100; ŹrMon 27, 176-178.

30 Augustine of Hippo, De moribus Ecclesiae catholicae, 1,31,67: NBA 13/1, 98 (Polish transl. ŹrMon 27, 176).

31 For more see: C. W. Brockwell, Augustine's ideal of monastic community. A paradigm for his doctrine of the Church, "Augustinian Studies" 8 (1977), p. 97-109; W. Geerlings, Das Freundschaftsideal Augustinus, "Theologische Quartalschrift” 16 (1981), p. 265274; J. Mc Evoy, "Anima una et cor unum". Friendship and spiritual unity in Augustine, "Recherches de Théologie Ancienne et Médievale” 53 (1986), p. 40-92.

32 Augustine of Hippo, De moribus Ecclesiae catholicae, 1,31,67: "Nemo quidquam possidet proprium, nemo cuiquam onerosus est. Operantur manibus ea quibus et corpus pasci possit et a Deo mens impediri non possit. Opus autem suum tradunt eis quos decanos vocant, eo quod sint denis praepositi, ut neminem illorum cura sui corporis tangat neque in cibo neque in vestimento neque si quid aliud opus est vel quotidianae necessitati vel mutatae, ut assolet, valetudini”: NBA 13/1, p. 98. English transl.: http://www.newadvent. org/fathers/1401.htm. 
monasticism, became over time a universal standard of communal monastic poverty in the Western Church. It derived from admiration for Egyptian coenobitism and was clearly formulated in the context of communal living which was shared by all monks of a given community. It was perhaps a legacy from the first Christian community of Jerusalem idealised by Luke, although Augustine did not refer directly to Luke's example of an ideal community in his On the Morals of the Catholic Church (388). It must be noted that the ascetic virtue of voluntary poverty, consisting in the renunciation of private property for the sake of collective property, was closely connected with an obligation of work for the community. Each monk should work individually, and Augustine emphasised Coenobites' manual work whose products were to be handed over to superiors for good of community. ${ }^{33}$

In his Expositions of the Psalms (commentary on psalm 94:7-8), written in Hippo Regius in 393/394, Augustine discussed Acts 4:32$35:{ }^{34}$ the fundamental text of the New Testament concerning the vision of an ideal community which greatly inspired the monastic movement in its efforts to achieve perfection from the $3^{\text {rd }} / 4^{\text {th }}$ century. As Domingo Sanchis noted, the commentary on Ps $94: 7-8$ initiated in Augustine's writings the whole range of enthusiastic references to Acts 4:32-35, ${ }^{35}$ and Luke's vision of the Jerusalem community became for Augustine an illustration of a great triumph

33 More on the Christian obligation of work according to Saint Augustine see: A. Sanchez Corazo, El trabajo en el pensamiento de san Agustín, “Augustinus" 30 (1985), p. 257294; on the work of the monk in St. Augustine's thought see: J. Śrutwa, Praca $w$ starożytnym chrześcijaństwie afrykańskim, Wyd. Towarzystwa Naukowego KUL, Lublin 1984, p. 237-283.

34 Augustine of Hippo, Enarratio in Psalmum, 94,7-8: NBA 27/1, a cura di T. Mariucci, V. Tarulli, Città Nuova Editrice Roma $1993^{2}$, p. 317-320.

35 D. Sanchis, Pauvreté monastique et charitè fraternelle, op. cit., p. 13, footnote 17 (Epistolae ad Galatas expositionis, 36 [an. 393-396]; Sermo, 252,3 [18 avril 396]; De doctrina cristiana, 3,6,10 [an. 397]; Sermo, 116,6 [an. 400-405]; Enarratio in Ps, 73,5 [an. 411]; Enarratio in Ps, 101,14-15 [an. 411]; Enarratio in Ps, 46,4 [an. 412]; Enarratio in Ps, 66,9 [an. 412-413]; Enarratio in Ps, 93,8 [an. 414]; Enarratio in Ps, 144,2 [an. 414]; Enarratio in Ps, 131,5.17 [an. 414-415]; Enarratio in Ps, 79,9 [an. 415 sq.]; Enarratio in Ps, 77,44 
The studies regarding monasticism and voluntary poverty...

of the Christian community over the Jewish community. In his commentary to Ps 95(94):7, Augustine stated that God did not completely reject the Jewish people because during Christ's life, God chose from among them disciples who were after all Jewish, ${ }^{36}$ and then, thousands of people converted to God so radically that they sold their possessions and placed them at the Apostle's feet. ${ }^{37}$ This clear allusion to Acts 4:32-35 served Augustine as an illustration that only those Jews who were Apostles or were converted were the eschatological wheat, while the rest constituted the chaff destined to be burnt in unquenchable fire - a clear reference to Mt 3:12. This eschatological key to understanding poverty as a symbol of conversion to God (contained in such writings as Sermon 252 (395 AD or 396 AD); ${ }^{38}$ Commentary on the Letter to Galatians ${ }^{39}$ (years 393396), On Christian doctrine (397 AD), ${ }^{40}$ Sermon 350A (around 399 AD), ${ }^{41}$ Sermon 301A (between 397 a 399) ${ }^{42}$ with time will be combined with the ecclesiastic interpretation of voluntary poverty as the symbol of church unity and love.

In the early Augustine's reflections, devoted indirectly to voluntary poverty, the voluntary poverty turns out to be not an independent virtue but an aspect of cognition, spiritual freedom, material and external deprivation, which enables better service

[an. 415]; In Joan, 15,4,26 [an. 415]; Enarratio in Ps, 78,2 [an. 415-416]; Epistula, 186,8,31 [an. 417]; Sermo, 77 A,3-4, an. 414-416]).

36 Augustine of Hippo, Enarratio in Psalmum, 94,7: NBA 27/1, 316.

37 Augustine of Hippo, Enarratio in Psalmum, 94,7: "Sic autem omnia illa conversa sunt millia hominum, ut res suas venderent, et pretia rerum suarum ante pedes Apostolorum ponerent": NBA 17/1, 318.

38 Augustine of Hippo, Sermo, 252,3: NBA 32/2, a cura di P. Bellini et al., Città Nuova Editrice, Roma 1984, p. 752.

39 Augustine of Hippo, Epistolae ad Galatas Expositionis, 14: NBA 10/2, a cura di S. Caruana et al, Città Nuova Editrice, Roma 1997, p. 584, 586; ibid., p. 26: NBA10/2, 612.614.

40 Augustine of Hippo, De doctrina cristiana, 3,6,10: NBA 8, a cura di M. Naldini et al., Città Nuova Editrice, Roma 1992, p. 148.

41 Augustine of Hippo, Sermo, 350/A,4: NBA 34, a cura di V. Paronetto, F. Monteverde, Città Nuova Editrice, Roma 1989, p. 154, 156.

42 Augustine of Hippo, Sermo, 301A,4: NBA 33, a cura di A. Quacquarelli, M. Recchia, Città Nuova Editrice, Roma 1986, p. 478. 
to Christ, leads to internal integrity, simplicity of heart, and entrusting oneself to God. ${ }^{43}$ Favouring the coenobitic model of monasticism, Augustine emphasized the collective lifestyle of monks as well as the unity of faith and morals. In the coenobitic context, monastic poverty means the lack of property but also not being a burden to other people. According to Augustine, the ascetic virtue of voluntary poverty involved both the renunciation of private property for the sake of the collective property and the obligation of work for the community which applied to all monks with no exceptions.

\section{Augustine's mature/late reflections on the issue of voluntary monastic poverty}

Apart from the early theological reflections on monasticism and the concept of voluntary poverty, Augustine's writings from $397 \mathrm{AD}$ onwards also contain the developing thought on monastic poverty, which is motivated by the love for Christ and the willingness to serve him as well as by the desire for God and for eternal life. The poverty understood as monastic virtue is no longer represented as divestment, but as the union with Christ, with God, that occurs in Church. Augustine refers directly to the text of Acts 4:32-36 as the source of thought on ascetic poverty, which should lead to the ecclesiastical oneness and the oneness of the heart with God. What is characteristic of voluntary poverty thus understood is: the renunciation of material possessions, love shown to one's neighbour and the union of heart and soul. ${ }^{44}$

\footnotetext{
43 D. Sanchis, Pauvreté monastique et charitè fraternelle, op. cit., p. 14-15.

44 D. Sanchis, Pauvreté monastique et charitè fraternelle, op. cit., p. 17-21.
} 
The studies regarding monasticism and voluntary poverty...

Praeceptum written in 397 is the most significant text containing Augustine's reflections on voluntary poverty. ${ }^{45}$ The first principle of the Augustinian monasticism was spelled out at the very beginning of the Augustinian rule:

The main purpose for you having come together is to live harmoniously in your house, intent upon God in oneness of mind and heart. ${ }^{46}$

and then it was repeated at the end of the first chapter:

Let all of you then live together in oneness of mind and heart, mutually honouring God in yourselves, whose temples you have become. ${ }^{47}$

Talking about "oneness of mind and heart," Augustine clearly refers to Acts 4:32. As Luc Verheijen points out, the corresponding texts of Augustine reveal that for Augustine „anima una” means „anima unica Christi,” hence also „anima unica Ecclesiae.” The Augustinian monastery is therefore based on understanding and learning the ability to think and act in line with the Church's teachings ('to feel in Spirit of the Church' ["spiritus Ecclesiae"]), and acquiring the way of thinking that befits the members of the Body of Christ. ${ }^{48}$ Understating the Spirit of Church was also possible

45 St. Augustine of Hippo, De Regula: NBA 8/1, text L. Verheijen, a cura di N. Cipriani, Città Nuova Editrice, Roma 2001, p. 30-49; Polish transl.: Regula św. Augustyna, [in:] św. Augustyn, Pisma monastyczne, ŹM 27, tłum. P. Nehring, Kraków 2002, p. 151-168.

46 Augustine of Hippo, Praeceptum, 1,2: "Primum, propter quod in unum estis congregati, ut unianimes habitetis in domo et sit vobis anima una et cor unum in Deum": NBA 8/1, 30, ŹrMon 27, 155. http://www.fordham.edu/halsall/source/ruleaug.html

47 Augustine of Hippo, Praeceptum, 1,8: "Omnes ergo unanimiter et concorditer vivite, et honorate in vobis invecem Deum cuius templa facit estis”: NBA 7/1, 32; ŹrMon 27, 157.

48 L. Verheijen, Acts 4:31-35 in the monastic texts of Saint Augustine, [in:] Second annual course on Augustinian spirituality, ed. R. Russel, Pontifical Biblical Institute Press, Rome 1976, p. 47-59; L. Verheijen, Acts 4:32a in Augustinian theology, [in:] Second 
for Anchorites, but according to Augustine, the communal dimension of church life was more important than the solitary model of monastic asceticism. ${ }^{49}$ For this reason, in Praeceptum Augustine puts emphasis on the communal life which is supposed to facilitate attaining salvation..$^{50}$

Following the principle of oneness in the communal way to God, Augustine introduced another rule for his monks, namely the renunciation of private property for the sake of collective property. This rule, which also referred to Acts 4:32-35, was supposed to regulate the life of his brethren. What inspired Augustine here was the practice of the first Jerusalem community of Christians, where according to Luke, everybody renounced their property and offered it to Church, where no one possessed anything and where material goods were held in common and distributed according to the need. The passage from Praeceptum 1,3 reads as follows:

Call nothing your own, but let everything be yours in common. Food and clothing shall be distributed to each of you by your superior, not equally to all, for all do not enjoy equal health, but rather according to each one's need. For so you read in the Acts of the Apostles that they had all things in common and distribution was made to each one according to each one's need..$^{51}$

annual course..., op. cit., p. 59-66; L. Verheijen, Saint Augustine's monasticism in the light of acts 4,32-5, Villanova University Press, Villanova 1979, p. 40-47; cf. T. J. van Bavel, Parallèles, vocabulaire et citations bibliques de la Regula sancti Augustini, "Augustiniana" 9 (1959), p. 12-77.

49 Augustine of Hippo, De moribus Ecclesiae catholicae, 30,64-31,65: NBA 13/1, 94.96; cf. N. Lanzi, La Chiesa nel ritorno di Agostino alla fede cattolica, "Doctor Communis" 42 (1989), p. 42-62.

50 L. Verheijen, Regula Augustini, [in:] DIP 7, a cura di G. Rocca, Roma 1983, p. 1550.

51 Augustine of Hippo, Praeceptum, 1,3: "Et non dicatis aliquid proprium, sed sint vobis omnia communia, et distribuatur unicuique vestrum a praepositio vestro victus et tegumentum, non aequaliter omnibus, quia non aequaliter valetis omnes, sed potius unicuique sicut cuique opus fuerit. Sic enim legitis in Actibus Apostolorum, quia 'erant illis omnia communia et distribuibatur unicuique sicut cuique opus erat": NBA 7/2, 30; Polish transl.: ŹrMon 27, 155; cf. Ordo monasterii, 4: ŹrMon 27, 152. 
The studies regarding monasticism and voluntary poverty...

The spirit of oneness and community characteristic of Augustinian monasticism indicates that the purpose of the monastic life is to seek salvation collectively and in unity , and that individual poverty and holding all goods in common, as practiced by Augustinian Coenobites, are the best means to attain salvation. Angelo Le Proust noticed at the end of the $17^{\text {th }}$ century $(\dagger 1697),{ }^{52}$ and Luc Verheijen later reiterated his words, that in Augustine's point of view, brothers gathered together in a monastery to help one another to achieve salvation. So, for Augustine salvation had a collective and ecclesiastical dimension. In this particular context, the ideal of individual poverty and holding all things in common imitated oneness and unity of the ancient Church of Jerusalem, as described in Acts 4:32-35. Augustine, like Luke in Acts of Apostles, diversified the distribution of goods: each brother was to receive them according to his needs, although he should only get an absolute minimum of goods, ${ }^{53}$ "For it is better to suffer a little want than to have too much.. ${ }^{54}$ According to Aimé Solignac, Augustine's statement - "Food and clothing shall be distributed to each of you by your superior, not equally to all, for all do not enjoy equal health, but rather according to each one's need" - referred to the Pachomian idea of "koinonii", while simultaneously differing from it, as Augustine greatly emphasised the principle of equality of all brothers in a community. This difference was most probably a result of different social conditions of a monastic recruitment process in Egypt at the beginning of the $4^{\text {th }}$ century and in Africa at the turn of the $5^{\text {th }}$ century. What is significant, though, is the fact that the main difference between Pachomius and

\footnotetext{
52 A. Le Proust, Traité de la Règle de saint Augustin, Paris $1980^{2}$, p. 18.

53 L. Verheijen, Regula Augustini, op. cit., k. 1550.

54 Augustine of Hippo, Praeceptum, 1,5: "melius est enim minus egere, quam plus habere": NBA 7/2, 30; ŹrMon 27, 159. A similar sentence can be encountered in Seneca's writings - Seneca Lucius Annaeus, Epistulae morales ad Lucilium, 2, 6: "Non qui parum habet, sed qui plus cupit, pauper est": http://www.intratext.com/IXT/LAT0230/_P2.HTM, and in Minucjusza Feliksa: Minutius Felix, Octavius, 36: "magis pauper ille est qui, quum multa habeat, plura desiderat”: PL 3, 351. Augustine most probably paraphrased Seneca.
} 
Augustine was that the letter demonstrated greater care towards each individual monk and that he noticed their individuality. For this reason, Solignac differentiated between Augustine's qualitative equality ("égalité qualitative") and Pachomius's quantitative equality ("égalité quantitative"). ${ }^{55}$

The principle of qualitative equality is discussed in the precepts 1, 4-7 of Praeceptum. From the brothers who acquired some goods before they entered the monastery Augustine demanded that they voluntarily shared them in common. ${ }^{56}$ Those who did not own anything before entering the monastery should not look for those things in the monastic house that they could not have before.$^{57}$ The community should provide them with essentials: food and clothing. Because of the unity in seeking God, Augustine warned the brothers of the lower social status not to seek after what is vain in the community, "Otherwise, monasteries will come to serve a useful purpose for the rich and not the poor, if the rich are made humble there and the poor are puffed up with pride" ${ }^{58} \mathrm{He}$ also told the brothers of the high or wealthy social class not to look down upon the brothers of the lower social class, not to take pride in their former ranks, and not to be conceited because of the goods they had left. Such behaviours would be manifestation of pride which destroys the effects of good deeds. ${ }^{59}$

Speaking of the issue of qualitative equality in observing the norms of monastic poverty, Augustine also discussed the norms regarding food, bedding, and clothing. He suggested, for instance, that distributed clothes should depend on monks' age or their physical condition. Also food should vary: some should be allowed more

\footnotetext{
A. Solignac, Pauvreté chrétienne. II/2, op. cit., p. 644.

Augustine of Hippo, Praeceptum, 1,4: NBA 7/2, 30; ŹrMon 27, 155.

Augustine of Hippo, Praeceptum, 1,5: NBA 7/2, 30; ŹrMon 27, 155-156.

58 Augustine of Hippo, Praeceptum, 1,6: "ne incipiant esse monasteria divitibus utilia, non pauperibus, si divites illic humiliantur et pauperes illic inflantur": NBA 7/2, 30;

59 Augustine of Hippo, Praeceptum, 1,7: NBA 7/2, 33; ŹrMon 27, 156-157.
} ŹrMon 27, 156. 
The studies regarding monasticism and voluntary poverty...

delicate meals while others should have more ascetic diet. The same applied to bedding. He also emphasised that these arrangements should not be a source of annoyance or indignation to the others. ${ }^{60}$ In brief, Augustine thus advised the brothers: "Nor should all want to receive what they see given in larger measure to the few, not as a token of honor, but as a help to support them in their weakness. This would give rise to a deplorable disorder - that in the monastery, where the rich are coming to bear as much hardship as they can, the poor are turning to a more genteel way of life". ${ }^{61}$

Augustine's Letter 157 was written as a response to false ascetic propositions regarding radical renunciation of property by Christians formulated in the Pelagian treatise De divitiis. ${ }^{62}$ An anonymous author ${ }^{63}$ of this work rejected all wealth and promoted compulsory material equality of all Christians. ${ }^{64}$ Augustine's letter in question was written at the end of 414 / at the beginning of 415 AD to Hilary, the bishop of Syracuse, where Pelegians were particularly active. Perhaps even the anonymous author of $D e$ Divitiis lived there. Commenting on the passage from Luke 18:25, Augustine came to the conclusion that both Christian renunciation of wealth and Christian use of wealth (just, good and prayerful) were the gift of grace. ${ }^{65}$ Neither Christ nor Paul the Apostle

60 Augustine of Hippo, Praeceptum, 3,3-5: NBA 7/2, 34; ŹrMon 27, 158-159.

61 Augustine of Hippo, Praeceptum, 3,4: "Nec debent velle omnes, quod paucos vident amplius, non quia honorantur, sed quia tolerantur, accipere, ne contingat detestanda perversitas, ut in monasterio, ubi, quantum possunt, fiunt divites laboriosi, fiant pauperes delicati": NBA 7/2, 34; ŹrMon 27, 158.

62 Anonimus, De Divitiis, [in:] Briefe, Abhandlungen und Predigten, Hrsg. C. P. Caspari, Christiania 1890, p. 25-67; PLS 1, 1380-1418; cf. A. Kessler, Reichtumskritik und Pelagianismus. Die pelagianische Diatribe "De divitiis", "Paradosis" 43, Freiburg (Schweiz) 1999; S. Toscano, Tolle divitem. Etica, società e potere del "De divitiis", Edizioni del Prisma, Catania 2006 (Collana: Testi e studi di storia antica).

63 G. Bonner, Augustine and modern Research on Pelagianism, St. Augustine Lecture 1971, Villanova 1972, p. 7-8, suggested that the author of the Pelagian's treatise De divitiis is probably so-called Anonyme sicilien.

${ }_{64}$ De Divitiis, 6, 3: PLS 1, 1386-1387.

65 Augustine of Hippo, Epistola, 157, 4, 29: NBA 22, 620, 622. 
demanded the renunciation of material possessions from the faithful. Instead, they prioritised the lack of excessive pride and only then they commanded the proper use of possessions ${ }^{66}$ Augustine emphasised the fact that Paul just required the proper use of goods (1 Tm 6:17-19). For the believer Christ is the highest value ${ }^{67}$ and every Christian can enjoy the right to own material possessions, to acquire them in a fair way, ${ }^{68}$ to manage them in an honest way, ${ }^{69}$ to share the surplus with the needy, ${ }^{70}$ because the rich who fear God will also inherit heaven. ${ }^{71}$

Looking at some Augustine's sermons, we can observe how his teachings on monastic poverty were observed in his own monastic community. In Sermon 355 (December 425/January 426) and Sermon 356 Augustine discusses the life and customs of his monks. What partially motivated Augustine to write these sermons was his desire to refute slanders and slurs that were casted on his brethren. ${ }^{72}$ Delivering Sermon 355 in a sitting position, ${ }^{73}$ Augustine first rhetorically apologised his listeners for his senile loquacity, ${ }^{74} \mathrm{ex}-$ plained that he would not take long and weary them and then referred to the text of Acts 4:32 to justify the necessity to renounce private property for the sake of the common fund. ${ }^{75} \mathrm{He}$ also declared that both himself and his brethren renounced their personal material goods for the sake of community. ${ }^{76}$ All the brothers of the Augustinian community in Hippo were to live off the common

66 Augustine of Hippo, Epistola, 157, 4, 26-27: NBA 22, 618, 620.

67 Augustine of Hippo, Epistola, 157, 4, 33: NBA 22, 626; cf. 1 Tm 6:17; 1 Cor 7:30-31.

Augustine of Hippo, Epistola, 157, 4, 37: NBA 22, 630; cf. Luke 16:9.

9 Augustine of Hippo, Epistola, 157, 4, 32-33: NBA 22, 624, 626.

Augustine of Hippo, Epistola, 157, 4, 34: NBA 22, 626, 628.

Augustine of Hippo, Epistola, 157, 4, 37: NBA 22, 630.

2 Augustine of Hippo, Sermo, 356,15: NBA 34, 274, 276; ŹrMon 27, 447.

3 Augustine of Hippo, Sermo, 355,1.2: NBA 34, 244; ŹrMon 27, 422.

74 Augustine of Hippo, Sermo, 355,4.7: NBA 34, 256; ŹrMon 27, 432.

75 Augustine of Hippo, Sermo, 355,1.2: NBA 34, 244; ŹrMon 27, 422.

76 Augustine of Hippo, Sermo, 355,1.2: NBA 34, 246; ŹrMon 27, 423. 
The studies regarding monasticism and voluntary poverty...

possessions and God should be their greatest value. ${ }^{77}$ He emphasised the fact that in his community no one could retain any private property. ${ }^{78}$

The counterexample to this ideal was the case of Januarius a priest living in the Augustinian community - who as a widower dispensed most of his private property to the poor, but retained a part of it silver to himself. He claimed to leave it for his daughter. However, it turned out that his daughter had joined a female monastery, and being a minor, could not manage her fathers' money. ${ }^{79}$ Januarius had a son who also joined the monastery. ${ }^{80}$ When confronted with the eminence of his death, he made his will in which he disinherited his daughter and his son ${ }^{81}$ and he left his money to the Church, which made Augustine the beneficiary. The bishop of Hippo bemoaned the fact that Januarius joining the monastery claimed to renounce his property which he in fact had kept and wanted to administer it before his death. ${ }^{82}$ What is more, Januarius's decisions set his children at variance. ${ }^{83}$ Augustine hoped to quickly reconcile the children who had already embarked on the monastic path. ${ }^{84}$ During the trial between the siblings, they settled the matter and reconciled and following Augustine's advice, they divided their father's money equally among themselves.$^{85} \mathrm{We}$ can only assume that if Januaries's children persevered in their monastic vocation, they eventually had to renounce their inheritance and donate it to their respective monastic communities. Augustine also mentioned

\footnotetext{
Augustine of Hippo, Sermo, 355,2: NBA 34, 246; ŹrMon 27, 423.

Augustine of Hippo, Sermo, 355, 2.2: NBA 34, 246, 248; ŹrMon 27, 424.

Augustine of Hippo, Sermo, 355, 2.3: NBA 34, 248; ŹrMon 27, 424-425.

Augustine of Hippo, Sermo, 355, 2.3: NBA 34, 248; ŹrMon 27, 425-426.

Augustine of Hippo, Sermon 355, 2.3: NBA 34, 248; ŹrMon 27, 425.

Augustine of Hippo, Sermo 355, 2.3: NBA 34, 248; ŹrMon 27, 424-425.

Augustine of Hippo, Sermo 355, 2.3: NBA 34, 248; ŹrMon 27, 426.

Augustine of Hippo, Sermo 355, 2.3: NBA 34, 248.250; ŹrMon 27, 426; cf. Ibid. 2.4.

Augustine of Hippo, Sermo 356,11: NBA 34, 268; ŹrMon 356, 442.
} 
another case when he accepted the inheritance which "should fall to Julian's son. Why? Because he died childless" ${ }^{86}$

Because of the Januaries's case, Augustine commanded his brethren to regulate their financial matters if they had not done so yet. He told his brothers that if they wanted to live in the community with him, they should sell, distribute, donate their property or to put it to the common fund. They should be prepared to be provided for by God through his Church. He also added that he they ought to made their decision by Epiphany. ${ }^{87}$ Augustine decided that he would not ordain brothers who refused to renounce their property so that he did not have to deprive them of Holy Orders should they desire to cancel their vows of leading the communal life, that is the life of poverty. ${ }^{88}$ As for the brothers who had already taken the vows, the bishop of Hippo let them decide to either stay in or leave the community. He said that those who did not find God and His church sufficient could stay wherever they wanted and that he would not deprive them of their clerical state. ${ }^{89}$ He expressed a similar view in Sermon 356, saying that those who wanted to retain their property and to act against his command could not remain in the monastery but would not be removed from ministry. He therefore did not retract his promise but expressed a great disappointment in those who made such a choice. He made them aware how wrong it was to fail to lead an ascetic life..$^{90}$ Augustine therefore

86 Augustine of Hippo, Sermo 355,4.5: "filii Iuliani hereditatem suscepi. Quare? Quia sine filiis defunctus est”: NBA 34, 252; ŹrMon 27, 428.

87 Augustine of Hippo, Sermo 355,4.6: "dixisse me fratribus meis, qui mecum manent, ut quicumque habet aliquid, aut vendat et eroget, aut donet aut commune illud faciat: Ecclesia habeat, per quam nos Deus pascit. Et dedi dilationem usque Epiphaniam": NBA 34, 252.254; ŹrMon 27, 429.

88 Augustine of Hippo, Sermo 355,4.6: NBA 34, 254.256; ŹrMon 27, 429-430.

89 Augustine of Hippo, Sermo 355,4.6: "qui volunt habere aliquid proprium, qui bus non sufficit Deus et Ecclesia eius, maneant ubi volunt et ubi possunt, non eis afero clericatum”: NBA 32, 254; ŹrMon 27, 430.

90 Augustine of Hippo, Sermo 356,14: “Qui habere voluerit aliquid proprium et de proprio vivere, et contra ista nostra praecepta facere, parum est ut dicam, non mecum manebit, sed clericus non erit. Dixeram enim, et scio me dixisse, ut si nolint suscipere socialem vitam 
The studies regarding monasticism and voluntary poverty...

criticized those who renounced ascetic vows of the communal life and of poverty but he recognized the choice of solitary priesthood as a possible form of the Church life. ${ }^{91}$ He doubted though that those brothers who had been monks and had given up monastic life in order to be clergymen outside the monastery possessed God and eternal happiness. ${ }^{92}$

In Sermon 356, Augustine reassured his audience again that all the lay and clergy brothers staying in his monastic community were "exactly as he wanted them to be", except for subdeacon Valens and Augustine's nephew Patrick. Valens still supported his mother and he had to resolve the possession of land and slaves that were jointly held by himself and his brother. Only once he came of age, which according to the Roman law was at twenty-five, could he divide the property by donating it (as was his wish) to the Church and free his slaves. ${ }^{93}$ Patrick in turn did not dispose of goods that he had inherited from his mother and did not clarify misunderstandings between himself and his sisters, which most probably pertained to some financial matters. ${ }^{94}$

Deacons Faustinus, ${ }^{95}$ Severus, ${ }^{96}$ an unnamed deacon of Hippo ${ }^{97}$ and Heraclius ${ }^{98}$ either disposed their material goods earlier in line with Augustine's will, or donated them to Church, thus being faultless. Augustine considered other deacons, who were not mentioned by name, ${ }^{99}$ and priests poor in the ascetic sense, that

\footnotetext{
mecum, non illis tollerem clericatum; seorsum maneret, seorsum viverent, quo modo possint Deo viverent. Et tamen ante oculos posui, quantum mali sit a proposto cadere": NBA 34, 272; ŹrMon 27, 444-445.

91 Augustine of Hippo, Sermo 355,4.6: NBA 34, 254; ŹrMon 27, 430.

92 Augustine of Hippo, Sermo 355,4.6: NBA 34, 256; ŹrMon 27, 431.

93 Augustine of Hippo, Sermon 356, 3: NBA 34, 260.262; ŹrMon 27, 435.

94 Augustine of Hippo, Sermo 356, 3: NBA 34, 262; ŹrMon 27, 435-436.

95 Augustine of Hippo, Sermo 356, 4: NBA 34, 262; ŹrMon 27, 436.

96 Augustine of Hippo, Sermo 356, 5: NBA 34, 262.264 ; ŹrMon 27, 437.

97 Augustine of Hippo, Sermo 356, 6: NBA 34, 264; ŹrMon 27, 437.

98 Augustine of Hippo, Sermo 356, 7: NBA 34, 264.266; ŹrMon 27, 437-438.

99 Augustine of Hippo, Sermo 356,8: NBA 34, 266; ŹrMon 27, 439.
} 
is, they did not own any property and all goods that they made over and produced were shared in common and controlled by the superior. ${ }^{100}$

\section{Conclusion}

The writings of Saint Augustine, the bishop of Hippo, contain the first relatively consistent ascetic doctrine of voluntary poverty in the theology of the Western Church. His thought developed gradually, inspired by the ideal of monastic life and the collective vision of Church. In the early reflections on voluntary poverty (between 386 to 396), Augustine rejected the Manichean vision of community and emphasized instead the Coenobitic view of poverty (the renunciation of private property, sharing all things in common, and work for the community). For Augustine, ascetic poverty was a symbol of converting to God and belonging to the eschatological community on Earth. Thus, the divestment of private property was a manifestation of spiritual freedom and readiness to serve God in the monastic community.

In his mature reflections on monastic poverty (the period between 397 to 426), the bishop of Hippo referred directly to the vision of ideal Christian community as presented in Act 4:32 which constituted for him the food for thought on voluntary poverty. Augustine justified monastic renunciation of property for the community by an ascetic interpretation of Luke's vision from Acts 4:32-36. He wanted his monks to emulate the communal dimension of the early Church. Augustine's idea of monastic poverty can be regarded as ascetic poverty in its qualitative dimension: Each monk was to receive according to his needs, but only the minimum of necessary goods. Disputing with Pelagians, Augustine rejected their thesis,

100 Augustine of Hippo, Sermo 356,9-10: NBA 34, 266; ŹrMon 27, 439-440. 
134 The studies regarding monasticism and voluntary poverty...

which he considered non-evangelical, about the compulsory poverty of all Christians. In Augustine's writings, one can also find some feedback on teaching monastic poverty: Sermon 355 (December 425/January 426) and Sermon 356 demonstrate the ways in which Augustine and his brothers practiced the individual and collective poverty. Majority of his priests, deacons and non-ordained brothers kept their vows of living in poverty. Acting as a Superior, Augustine attempted to solve the arisen problems connected with practicing monastic poverty by talking to each brother individually. As for the clergymen who decided to leave the monastic community thus breaching their vows of leading the impoverished collective life, Augustine criticized heavily their conduct, but he did allow for the solitary clergy life in Church. 


\section{VI}

\section{The Eustathian context of the monastic poverty doctrine in the ascetic writings of Basil the Great*}

In this article, the issue of poverty as a specific and voluntary ideal deriving from the monastic motivation will be discussed from the perspective of the ascetic writings of Basil the Great. The description of the ideal as well as the monastic poverty norms according to Basil's asceticism is preceded by the introduction to the issue of poverty idealization in the heterodox Eustathian movement in Asia Minor.

\section{The pre-Basilian concepts in Asia Minor - Estathius and the Eustathian Monasticism}

Eustathius of Sebaste (born approximately in 300 a.d - died in 380 a.d.), a son of Eulalius, a Bishop of Kaisareia in Cappadocia, ${ }^{1}$ was undoubtedly the most prominent representative of the pre-Basilian monasticism in Asia Minor. In all probability, he was under the in-

This article was originally published under the title: Eustacjański kontekst doktryny o ubóstwie monastycznym $w$ pismach ascetycznych Bazylego Wielkiego, "Vox Patrum" 30 (2010) t. 55, p. 257-273.

1 Eustathius of Sebaste, [in:] Stownik chrześcijańskiego piśmiennictwa, red. J. M. Szymusiak, M. Starowieyski, Poznań 1971, p. 139; J. Gribomont, Eustace de Sébaste, [in:] DSp 4, 1708; J. Gribomont, Eustazio di Sebaste, [in:] Nuovo dizionario patristico e di Antichità Cristiane, vol. 1, a cura di A. Di Berardino, Genova-Milano 2002, p. 1865. 
The studies regarding monasticism and voluntary poverty...

fluence of the teachings of Arius, ${ }^{2}$ a presbyter in Alexandria. With time, he expressed an unorthodox views about the non-divinity of the Holy Spirit. Basil the Great, ${ }^{3}$ who later became his student, tried to dissuade Eustathius from his views, although without success. Eustathius of Sebaste was excluded from the group of candidates for the priesthood ${ }^{4}$ by Eustathius of Antiocheia (born in 230 a.d. died 327 a.d.), a Bishop of Antiocheia of that time. However, before 325 a.d. he was ordained a presbyter by Hermogenes the Bishop. Then, he led a group questioning Church norms and habits. Eustathius and the members of his ascetic group were exposed to animosity of the members of the Church hierarchy ${ }^{5}$ because of their distinct attire. His father, Eulalius, Bishop of Kaisareia in Cappadocia, forbade him from attending church services, all the same punishing him for unorthodox views. ${ }^{6}$ In Pontus, Eustathius led a monastic life. This form of strict - though not Christian - asceticism gradually won him the affection of the local people. In 356, Eustathius was chosen an archbishop of Roman Armenia. ${ }^{7}$ However, due to wrong theological views and false asceticism, Eustathius was first excluded from the Church Community by the Synod of NeoCaesarea and next deposed from the office of bishop by Eusebius, Bishop of Nicomedia, for the neglectful management of church property, ${ }^{8}$ which was repeated at the Synod of Gangra. ${ }^{9}$

2 Basil the Great, Epistula 130,1: PG 32, 561.564; Epistula 223,3: PG 32, 824-828; PAX 16, tłum. W. Krzyżaniak, Warszawa 1972, p. 252-254.

3 Basil the Great, Epistula 223: PG 32, 820-833; PAX 16, 249-258.

4 Athanasius of Alexandria, Epistula ad episcopos Eagypti et Libyae 7: PG 25, 552556; Athanasius of Alexandria, Historia arianorum ad monachos 4: PG 25, 700A; Eustathius of Antioch, [in:] Stownik chrześcijańskiego piśmiennictwa, op. cit., p. 139.

5 Sokrates Scholasticus, Historia ecclesiastica 2:43: PG 67, 352-356; Polish transl.: Historia kościelna, PAX 27, tłum. S. Kazikowski, Warszawa 19862.

6 Eustathius of Sebaste, Stownik..., op. cit., p. 139.

J. Gribomont, Eustace de Sébaste, 1865.

8 Hermias Sozomenus, Historia ecclesiastica 4:24: PG 67, 1193; Polish transl.: Historia kościelna, PAX 21, tłum. S. Kazikowski, Warszawa 19892, p. 271.

9 Synod of Gangra, Synodic Letter 2, [in:] Acta Synodalia ann. 50-381. Synodi et Collectionum legum, t. 1, red. A. Baron, H. Pietras, tłum. S. Kalinkowski, ŹMT 37, Kraków 2006, ŹMT 37, 123*. 
At the Synod of Melitene in 358 a.d., Armenian Arians ${ }^{10}$ deposed him from his office as a bishop and later, after the Synod of Seleucia in 359, Roman Emperor Constantine II sent him into exile in Dardania at the Adriatic Sea. ${ }^{11}$ He got back to Sebaste in 361 a.d. during the reign of Julian the Apostate, Roman Emperor. Quite intriguingly, Pope Liberius ${ }^{12}$ acknowledged his theological views as orthodox. After meeting Basil and Basil's brother, Peter, in 373 a.d., Eustathius signed the orthodox Creed. ${ }^{13}$ However, succumbing to the negative influence of the environment, he again detached himself from the Church community and Basil of Kaisareia. In 376 a.d., he lead to deposing Gregory of Nyssa from the office of bishop and signed a pneumatomachian creed of Macedonians of Pontus. Soon after, he died, without reconciling himself with Basil the Great, ${ }^{14}$ though still considered an orthodox by Pope Damasius, ${ }^{15}$ though not reconciled with Basil the Great. ${ }^{16}$ According to the testimony of a Bisantine historian Hermias Sozomen (died in 450), it was Eustathian that had been the first to lead a monk life among Armenians, Paphlagonians and citizens of Pontus. ${ }^{17}$ We know that Eustathius of Sebaste paid a visit at all monk communities from Egypt up to Mesopotamia, which was later (357 a.d.) emulated by Basil the Great. ${ }^{18}$ The influence of Eustathius on Cappadocian monasticism, and especially on Basil's opinions, was significant. ${ }^{19}$ Basil

10 Hermias of Sozomenus, Historia Kościoła 4:25: PG 67, 1195-1197; PAX 21, 274-276.

11 Theodoret of Cyrus, Historia Kościoła 2:27: PG 82, 1080-1084.

12 Socrates Scholasticus, Historia Kościoła 4:12: PG 67, 484-496; PAX 27, 345-348.

13 Basil the Great, Epistula 119: PG 32, 536-537; Epistula 125: PG 32, 545-552; PAX 16, 153-157.

14 Basil the Great, Epistula 263: PG 32, 976-981; PAX 16, 328-332.

15 Damasus, Epistula 4,1: PL 13, 358.

16 Basil the Great, Epistula 263: PG 32, 976-981; PAX 16, 328-332.

17 Hermias of Sozomenus, Historia Ecclesiastica 3,14: PG 67, 1077C; PAX 21, 182.

18 Basil the Great, Epistula 1: PG 32, 219-221; PAX 16, 27-30; cf. J. Naumowicz, Wstęp, [in:] św. Bazyli Wielki, Pisma ascetyczne, t. 1, ŹM 5, Kraków 1994, p. 12.

19 Ch. A. Frazee, Anatolian asceticism in the Fourth Century. Eustathios of Sebastea and Basil of Caesarea, "The Catholic Historical Review" 66 (1980), p. 16-33; R. Pouchet, Basile le Grand et son univers d'amis d'après sa correspondence. Une strategie de 
The studies regarding monasticism and voluntary poverty...

had known Eustathius of Sebaste since childhood. ${ }^{20}$ The Monastic Rules of St. Basil were written in Eustathius-spirited way; some people, like Hermias Sozomen, suggested that Eustathius was their real author. ${ }^{21}$ Eustathius did not bequeath any of his writings, but some of his ideas may be found in the ascetic writings of Basil the Great and Pseudo Macarius. The form of asceticism by Eustathius must have been milder than his followers, especially the one of Aerius or later Messalians, who got separated from the radical wing of Eustathians. ${ }^{22}$ One of Eustathius's way to reconcile ascetic practices with the demands of the Church community was through establishing charitable institutions, such as ptochtropheion in Sebaste (later emulated by Basil the Great in Kaisareia in Cappadocia). However, this charitable activity became a source of criticism within his ascetic group. ${ }^{23}$ However, Eustathian monasticism was heterodox, which is clearly visible in the documents from the Synod of Gangra, ${ }^{24}$ from 340 a.d.,${ }^{25}$ which condemned unhealthy Eustathian asceticism as non-ecclesiastical ${ }^{26}$ and inconsistent with

communion, SEA 36, Roma 1992, p. 92; cf. R. Van Dam, Families and Friends in Late Roman Cappadocia, Penn, University of Pennsylvania Press, Philadelphia 2003.

$20 \quad$ Basil the Great, Epistula 244,1.8: PG 32, 912-913.921.

21 Hermias of Sozomenus, Historia Kościoła 3,14: PG 67, 1079; PAX 21, 182.

22 J. Gribomont, Le monachisme au IVe siècle en Asie Mineure. De Gangres au Messalianisme, "Studia Patristica" 2 (1957), p. 400-415; J. Gribomont, Le dossier des origines du messalianisme, [w:] Epaktasis. Mélanges offerts au cardinal J. Daniélou, Paris 1972, p. 611-625; C. Steward, "Working the earth of the heart". The Messalian controversy in history, Texts and language to 431, Oxford 1991.

23 J. Gribomont, Eustazio di Sebaste, op. cit., p. 1865-1866.

24 Synod of Gangra (circa 340): Przeciwko Eustatiosowi i przesadnej ascezie: ŹMT 37, $123 *-128 *$.

25 T. D. Barnes, The date of the Council of Gangra, "Journal of Theological Studies" 40 (1989), p. 121-124.

26 Synod of Gangra, Synodical Letter 2: English transl.: "For as much as the most Holy Synod of Bishops, assembled on account of certain necessary matters of ecclesiastical business in the Church at Gangra, on inquiring also into the matters which concern Eustathius, found that many things had been unlawfully done by these very men who are partisans of Eustathius, it was compelled to make definitions, which it has hastened to make known to all, for the removal of whatever has by him been done amiss." http://ecmarsh.com/fathers/ npnf2/NPNF2-14/Npnf2-14-39.htm. 
the Holy Writ and the Apostolic Tradition. ${ }^{27}$ Paphlagonian bishops accused the followers of Eustathian asceticism of creating a separate Church, separate liturgy and practicing their own cult in private homes, abandoning canonical Houses of God and churches. ${ }^{28}$ They fasted on Sundays, rejected canonical fasts and abhorred meat. ${ }^{29}$ They also scorned ordinary (short) attire, introducing long, foreign ${ }^{30}$ monk's or philosopher's robes. ${ }^{31}$ Eustathian women cut their hair ${ }^{32}$ and wore man's clothes. Astonishingly, the reasoning behind this change from woman's to man's clothes was that in this way women obtained justification. ${ }^{33}$ Following the made-up ascetic rules, Eustathians rejected the institution of marriage and family as they remained convinced that married people may not reachsalvation. ${ }^{34}$ Hence, they did not want to pray at married people's house ${ }^{35}$ and scorned married presbyters refusing the attendance in their services. ${ }^{36}$

27 Synod of Gangra, Epilogue 4: English transl.: "To sum up in a word, we wish that all things which have been delivered by the Holy Scriptures and the Apostolical traditions, may be observed in the Church.” http://ecmarsh.com/fathers/npnf2/NPNF2-14/Npnf214-39.htm.

28 Synod of Gangra, Synodical Letter 4: English transl.: “They were found, moreover, fomenting separations from the houses of God and of the Church; treating the Church and its members with disdain, and establishing separate meetings and assemblies, and different doctrines and other things in opposition to the Churches and those things which are done in the Church." http://ecmarsh.com/fathers/npnf2/NPNF2-14/Npnf2-14-39.htm.

29 Synod of Gangra, Synodical Letter 10: ŹMT 37, 124*.

30 Synod of Gangra, Synodical Letter 5: ŹMT 37, 124*.

31 Synod of Gangra, Canon 12: English transl.: "If any one, under pretence of asceticism, should wear a periboloeum and, as if this gave him righteousness, shall despise those who with piety wear the berus and use other common and customary dress, let him be anathema." http://ecmarsh.com/fathers/npnf2/NPNF2-14/Npnf2-14-39.htm.

32 Synod of Gangra, Synodical Letter 9: English transl.: "While many of them, under a pretext of piety, cut off the growth of hair, which is natural to woman." http://ecmarsh. com/fathers/npnf2/NPNF2-14/Npnf2-14-39.htm.

33 Synod of Gangra, Synodical Letter 8: ŹMT 37, 124*.

34 Synod of Gangra, Synodical Letter 3: ŹMT 37, 123*-124*.

35 Synod of Gangra, Synodical Letter 11: ŹMT 37, 124*: English transl.: "Neither do they tolerate prayers in the houses of married persons, but, on the contrary, despise such prayers when they are made, and often refuse to partake when Oblations are offered in the houses of married persons." http://ecmarsh.com/fathers/npnf2/NPNF2-14/Npnf2-14-39.htm.

36 Synod of Gangra, Synodical Letter 12: ŹMT 37, 124*. 
140 The studies regarding monasticism and voluntary poverty...

The Eustathian movement rejected the ascetic rules proposed by the Church, all the same abiding by their own, heterogeneous rules, as anyone, to their own and the Church detriment could bias the rules by adding any detail that came to their mind. ${ }^{37}$ The document from the Synod in Gangra (340 a.d.), first informed about the mistakes of Eustathians (the so-called Synodic Letter), and then, in Canons, ordered their exclusion from the Church. ${ }^{38}$ The bishops present at the Synod condemned heterodox practices of Eustathians and excluded them from the unity of Church if they remained in their false beliefs. However, if they came to their senses and condemned all wrongdoings, they would be accepted again..$^{39}$

The Eustathian movement postulated the idea of renunciation of material goods and the contempt of materialism and carnality. These issues were arranged into four thematic claims, to which documents of the Synod of Gangra related through opinions about false asceticism of Eustathians as well as through later rejection by the Church of false displays of asceticism considered as non-Christian:

- Eustathian views regarding the elevation of virginity and the renunciation of marriage:

- Synodical Letter 3: "For, from their utter abhorrence of marriage, and from their adoption of the proposition that no one living in a state of marriage has any hope towards God, many misguided married women have forsaken their husbands, and husbands their wives: then, afterwards, not being able to contain, they have fallen into adultery; and so, through such a principle as this, have come to shame." 40

- Canon 1: About those who abominate legal marriage. "41 "If any one shall condemn marriage, or abominate and condemn

\footnotetext{
Synod of Gangra, Synodical Letter 15: ŹMT 37, 124*.

Synod of Gangra, Canons 1-20: ŹMT 37, 125*-128*.

Synod of Gangra, Synodical Letter 16: ŹMT 37, 124*.

Synod of Gangra, Synodical Letter 3: http://ecmarsh.com/fathers/npnf2/NPNF2-

41 Cf. Decretum Gratiani D. XXX, 12 (109); D. XXXI 8 (113)
} 14/Npnf2-14-39.htm. 
a woman who is a believer and devout, and sleeps with her own husband, as though she could not enter the Kingdom [of heaven] let him be anathema." 42

- Synodical Letter 11: "neither do they tolerate prayers in the houses of married persons, but, on the contrary, despise such prayers when they are made, and often refuse to partake when Oblations are offered in the houses of married persons." ${ }^{43}$

- Synodical Letter 12: "contemning married presbyters, and refusing to touch their ministrations." 4

- Canon 4: "If any one shall maintain, concerning a married presbyter, that is not lawful to partake of the oblation when he offers it, let him be anathema." 45

- Canon 9: About those who remain virgin out of marriage abhorrence. ${ }^{46}$ "I any one shall remain virgin, or observe continence, abstaining from marriage because he abhors it, and not on account of the beauty and holiness of virginity itself, let him be anathema." ${ }^{47}$

- Canon 10: About those who extoll over virginity. 48 "If any one of those who are living a virgin life for the Lord's sake shall treat arrogantly the married, let him be anathema." 49

42 Synod of Gangra, Canon 1: http://ecmarsh.com/fathers/npnf2/NPNF2-14/Npnf214-39.htm.

43 Synod of Gangra, Synodical Letter 11: http://ecmarsh.com/fathers/npnf2/NPNF214/Npnf2-14-39.htm.

44 Synod of Gangra, Synodical Letter 12: http://ecmarsh.com/fathers/npnf2/NPNF214/Npnf2-14-39.htm.

45 Synod of Gangra, Canon 4: http://ecmarsh.com/fathers/npnf2/NPNF2-14/Npnf214-39.htm.

46 Cf. Decretum Gratiani D. XXXI 9 (113), http://ecmarsh.com/fathers/npnf2/NPNF214/Npnf2-14-39.htm.

47 Synod of Gangra, Canon 9: http://ecmarsh.com/fathers/npnf2/NPNF2-14/Npnf214-39.htm.

48 Cf. Decretum Gratiani D. XLII 1 (151).

49 Synod of Gangra, Canon 14: http://ecmarsh.com/fathers/npnf2/NPNF2-14/Npnf214-39.htm. 
142 The studies regarding monasticism and voluntary poverty...

- Canon 14: About the women who leave their husbands. ${ }^{50}$ "If any woman shall forsake her husband, and resolve to depart from him because she abhors marriage, let her be anathema." 51

- Canon 15: About those who neglect their children under the guise of piety. ${ }^{52}$ "If anyone shall forsake his own children and shall not nurture them, nor so far as in him lies, rear them in becoming piety, but shall neglect them, under pretence of asceticism, let him be anathema." 53

- Canon 16: About those who neglect their parents under the guise of piety. ${ }^{54}$ "If, under any pretence of piety, any children shall forsake their parents, particularly [if the parents are] believers, and shall withhold becoming reverence from their parents, on the plea that they honour piety ${ }^{55}$ more than them, let them be anathema." 56

- Eustathian views regarding the rejection of meat and noncanonical ways of fasting:

- Synodical Letter 10: "[and these persons were found] fasting on the Lord's Day, despising the sacredness of that free day, but disdaining and eating on the fasts appointed in the Church; and certain of them abhor the eating of flesh." 57

- Canon 2: About those who abhor eating meat. ${ }^{58}$ "If any one shall condemn him who eats flesh, which is without blood

50 Cf. Decretum Gratiani D. XXX 3 (108).

51 Synod of Gangra, Canon 14: http://ecmarsh.com/fathers/npnf2/NPNF2-14/Npnf214-39.htm.

52 Cf. Decretum Gratiani D. XXX 14 (109).

53 Synod of Gangra, Canon 15: http://ecmarsh.com/fathers/npnf2/NPNF2-14/Npnf214-39.htm.

54 Cf. Decretum Gratiani D. XXX 1 (107).

55 Mt 15:5-9.

56 Synod of Gangra, Canon 16: http://ecmarsh.com/fathers/npnf2/NPNF2-14/Npnf214-39.htm.

57 Synod of Gangra, Synodical Letter 10: http://ecmarsh.com/fathers/npnf2/NPNF214/Npnf2-14-39.htm.

58 Cf. Decretum Gratiani D. XXX, 13 (109). 
and has not been offered to idols nor strangled, ${ }^{59}$ and is faithful and devout, as though the man were without hope [of salvation] ${ }^{60}$ because of his eating, let him be anathema." 61

- Canon 18: About those who fast on Sundays. ${ }^{62}$ "If any one, under pretence of asceticism, shall fast on Sunday, let him be anathema." 63

- Canon 19: About those who do not obey Church fast days. ${ }^{64}$ "If any of the ascetics, without bodily necessity, shall behave with insolence and disregard the fasts commonly prescribed and observed by the Church, because of his perfect understanding in the matter, let him be anathema." ${ }^{\prime 5}$

- Eustathian views condemning wealth and private possession:

- Synodical Letter 14: "and [condemn] the rich also who do not alienate all their wealth, as having nothing to hope from God." 66

- Epilogue 2: "and we do not contemn wealth enjoyed with uprightness and beneficence." 67

- Eustathian views regarding leaving the master by a slave:

- Synodical Letter 7: "slaves also leaving their masters, and, on account of their own strange apparel, acting insolently towards their masters." 68

59 Cf. Acts 15:22; Apostolic Canons 63.

60 Cf. Synod of Toledo of 397/400, k. 21/17.

61 Synod of Gangra, Canon 2: http://ecmarsh.com/fathers/npnf2/NPNF2-14/Npnf214-39.htm.

62 Cf. Decretum Gratiani D. XXX 7 (108).

63 Synod of Gangra, Canon 18: http://ecmarsh.com/fathers/npnf2/NPNF2-14/Npnf214-39.htm.

64 Cf. Decretum Gratiani D. XXX 8 (108).

65 Synod of Gangra, Canon 19: http://ecmarsh.com/fathers/npnf2/NPNF2-14/Npnf214-39.htm.

66 Synod of Gangra, Synodical Letter 14: http://ecmarsh.com/fathers/npnf2/NPNF214/Npnf2-14-39.htm.

67 Synod of Gangra, Epilogue 2: http://ecmarsh.com/fathers/npnf2/NPNF2-14/ Npnf2-14-39.htm.

68 Synod of Gangra, Synodical Letter 7: http://ecmarsh.com/fathers/npnf2/NPNF214/Npnf2-14-39.htm. 
144 The studies regarding monasticism and voluntary poverty...

- Canon 3: About those who under the pretext of Christian life run away from their masters. ${ }^{69}$ "If any one shall teach a slave, under pretext of piety, to despise his master and to run away from his service, and not to serve his own master with good-will and all honour, ${ }^{70}$ let him be anathema." ${ }^{11}$

We know from the records of the Synod of Gangra (340 a.d.) that the Eustathian monasticism had a negative attitude towards basic displays of social life. The Eustathians motivated their heterodox ascetic theses with an eristic and extremely non-Christian reasoning that unjustifiably referred to refusing Salvation to anyone who thinks and acts differently than the Eustathians. This sort of ideologization was used as an eschatological intimidation of the opponents of the Eustathian contempt of marriage and private possession (cf. The Synod of Gangra, $3^{\text {rd }}$ and $14^{\text {th }}$ Synodic Letter and Canon 2). Paphlagonian bishops pointed out that scorn, loathing, condemnation and disregard for ideologically opposing groups were very characteristic of the Eustathian rhetoric (the Synod of Gangra, Canons 1, 9, 14 and 20). In a spirit of gnostic Encratites of the second century, the Eustathians renounced human materiality, therefore, manifested ascetic revulsion towards the institution of marriage and the displays of legal marital sexuality (cp. The Synod of Gangra, Synodic Letter 11-12, Canons 1, 4, 9, 10, 14). Similarly, the Eusathians condemned and scorned wealth and the legal and fairly employed personal property or incited slaves to leave their owners $^{72}$ (cp. The Synod of Gangra, Synodic Letter 7, 14, Canon 2, Epilogue 2).

\footnotetext{
69 Cf. Decretum Gratiani C. XVII, q. 4,c.37.

70 Cf. 1 Tim 6:1; Titus 2:9s.

71 Synod of Gangra, Canon 3: http://ecmarsh.com/fathers/npnf2/NPNF2-14/Npnf214-39.htm.

72 J. de Churruca, L'anathème du concile de Gangres contre ceux qui sous prétexte de Christianisme incite les esclaves à quitter leurs maîtres, "Revue d'histoire du droit" 60 (1982), p. 261-278.
} 
A characteristic feature of the synodical texts of Gangra is that Papflagonian bishops pointed out the pseudo piety of Eustathian ascetics, who, in the guise of godliness, neglected particular commandments of the covenant with God. They did not keep the holy days and fasted on Sundays (cp. The Synod of Gangra, Synodic Letter 10, Canon 18); also, they renounced honoring their parents (the Synod of Gangra, Canon 16). Paradoxically, in their false ascetic motivation, the Eustathians forgot about the commandments of love and, as parents, they neglected their children (the Synod of Gangra, Canon 15) or left their spouses (the Synod of Gangra, Canon 14). The shortcomings of the Eustathian asceticism were undoubtedly manifested in the form of great tensions between the pre-Basilian monasticism and local bishops. ${ }^{73}$

The decisions made at the Synod of Gangra in 340 a.d. had a significant influence on the development of Church legislation. The texts of the Synods of Gangra had been rendered from Greek into seven languages as early as in Ancient Times; it was translated into Latin, Syriac, Armenian, Georgian, Arabic, Ethiopian and Paleo-Slavic. ${ }^{74}$ Irrespective of the fact that the document was edited by Arian bishops, it was first included in the Byzantine Legal Collection and, later, most of the Canons of Gangra joined the western Decretum Gratiani. ${ }^{75}$ Very significant is the fact that Basil himself did not comment upon the administrative legitimacy of the Synodic Canons of Gangra. It might have been that he remained silent because the documents were passed by Arian bishops who, in turn, were backed by Arian emperors. ${ }^{76}$ Whereas in Basil's works, especially in The Morals, we find a clear-cut set of recommendations

73 J. Gribomont, Święty Bazyli - ewangeliczny rewolucjonista, "Roczniki Teologiczno-Kanoniczne. Historia Kościoła” 27 (1980) z. 4, p. 188-190.

74 Clavis Patrum Graecorum 8553-8554.

75 E. Schwartz, Die Kanonenssammlungen der alten Kirche, [in:] E. Schwartz, Gesammelte Schriften, Bd 4: Zur Geschichte der alten Kirche und ihres Rechtes, Berlin 1960, p. 192-196.

76 J. Gribomont, Święty Bazyli - ewangeliczny rewolucjonista, op. cit., p. 186. 
146 The studies regarding monasticism and voluntary poverty...

regarding the core of the real asceticism that is in agreement with the teachings of the Church. ${ }^{77}$ Jean Gribomont demonstrated that Basil's attitude towards monasticism was understandable in the context of the Eustathian tradition, and, more often than not, on the basis of the opposition towards it. ${ }^{78}$ Józef Naumowicz, on the other hand, justly observes that the ascetic sources of St. Basil were also addressed towards the community of Eustathian ascetics, whom he knew; however, these were the original writings that imposed order on the asceticism in Asia Minor of the fourth century. ${ }^{79}$ The question to be answered now is what was the condition of the voluntary poverty concept according to St. Basil the Great in the context of the heterodox Eustathian monasticism and the resolutions of the Synod of Gangra?

\section{The concept of monastic poverty in the ascetic writings of St. Basil the Great}

Contrary to the heterodox Eustathian asceticism, the asceticism of St. Basil the Great (329-379 a.d.) was clearly biblical and ecclesial. ${ }^{80}$ For Basil, the Word of the Holy Bible was the only norm of the ascetic life, and his teachings were treated by the Bishop of Caesarea as the practical implementation of the Biblical teachings. Therefore, fulfilling the Word of God remained the only way to perfection. Basil also wanted to avoid accusations of retreating from the Church in his understanding of the monastic life. That is why

77 J. Naumowicz, Wstęp, ŹM 5, 19.

78 J. Gribomont, Saint Basile et le monachisme enthousiaste, "Irénikon" 62 (1980), p. $123-144$.

79 J. Gribomont, Saint Basile et le monachisme enthousiaste, "Irénikon" 62 (1980), p. $123-144$.

80 M. Girardi, Erotapokriseis neotestamentaria negli Ascetica di Basilio di Cesarea. Evangelismo e paolinismo nel monachesimo delle origini, "Annali di storia dell'esegesi” 11/2 (1994), p. 461-490. 
he steered clear from such terms as "monk" and "monastery," and instead employed such terms as "brothers" and "brotherly community." ${ }^{11}$ In the spiritual life, love should take precedence over other values. The love towards God necessitates exclusivity and an indivisible heart. The love towards a fellow human being, on the other hand, requires a communal way of living. ${ }^{82}$

Cenobitism was a way of monastic life favored by St. Basil due to the fac that it enabled a better and fuller realization of the ideal, namely, the Christian mercy. ${ }^{83}$ Cenobium understood as a monastic community should not, according to St. Basil, be too numerous a community, but should be integrated with the whole Church community so that it could combine the requirement of intentness and temporary solitude with pastoral and charitable activities of the Church. ${ }^{84}$ The life of a Basilian monk boiled down entirely to practicing brotherly love in obedience. ${ }^{85}$ Through that, a Christian ascetic realized a basic act of obedience towards God; he followed the word of Gospel, appealed to God and observed the Covenant and the Commandments. ${ }^{86}$ Therefore, the charitable activity and founding hospices, including "La Basiliade," is understandable. ${ }^{87}$ The Basilian sermons of a social nature and the charitable activity of the famine of 368-369 a.d., resulted mainly from

81 J. Naumowicz, Wstęp, [in:] św. Bazyli Wielki, Pisma ascetyczne, t. 2, ŹM 6, Kraków 1995, p. 25-26.

82 J. Naumowicz, Wstęp, ŹM 6, p. 26-27.

83 J. Górny, Wpływ św. Bazylego na rozwój życia monastycznego, "Vox Patrum" 3 (1982), p. 299; cf.: S. Scicolone, Basilio e la sua organizzazione dell'attività assistenziale a Cesarea, "Civiltà Classica” 3 (1982), p. 353-372; M. Forlin Patrucco, Social Patronage and Political Mediation in the Activity of Basil of Caesarea, "Studia Patristica" 17 (1982) 3, p. 1102-1107.

84 J. Górny, Wpływ św. Bazylego na rozwój życia monastycznego, op. cit., p. 307.

85 S. Giet, Les idées et l'action sociale de Saint Basile, Paris 1941, p. 200-203.

86 Basil the Great, De judicio Dei 5: PG 31, 661-665; Polish transl.: O Sądzie Bożym 8: ŹM 5. Pisma ascetyczne, t. 1, tłum. J. Naumowicz, Kraków 1994, p. 80-81 (cf. Ef 5:6; Ps 103:18).

87 J. Naumowicz, Instytucje charytatywne św. Bazylego. "Bazyliada", "Vox Patrum" 16 (1996) z. 30-31, p. 125-139. 
148 The studies regarding monasticism and voluntary poverty...

the inspirations with the evangelical love towards the fellow human being, whereas Jesus remained its model. Indirectly, however, Eustathius of Sebaste and his charitable activity remained Basil's model. ${ }^{88}$

Basil's answer to the forms of social life ${ }^{89}$ contested by the Eustathian monasticism was formed in The Morals 70-79: about deacons and priests, blameless men, whose life was found worthy (Rule 70); ${ }^{90}$ about choosing bishops, priests and deacons (Rule 71), ${ }^{91}$ about the hearers examining what is said by the teachers (Rule 72);92 about remaining in marriage and abiding by its rules (Rule 73); ${ }^{93}$ about the life in widowhood (Rule 74); ${ }^{94}$ about the obedience of slaves towards their masters and the respect of masters towards their slaves (Rule 75);95 about reverent childhood and patient parenting (Rule 76); ${ }^{96}$ about virgins free from solicitude for this world (Rule 77); ${ }^{97}$ about soldiers free from violence and false accusations (Rule 78); ${ }^{98}$ and about the custodian role of the rulers (Rule 79). ${ }^{99}$

J. Gribomont observed that the Basilian The Morals also emphasized the theologically central place of Salvation in Christ and the sanctifying role of baptism and the Eucharist - the Mysteries of

88 Ch. A. Frazee, Anatolian Asceticism in the Fourth Century, op. cit., p. 23-24; P. Kochanek, Nauczanie spoteczne Bazylego Wielkiego. Zagadnienia wybrane, "Summarium KUL” 16-17 (1987-1988), p. 119-123.

89 J. Gribomont, Święty Bazyli - ewangeliczny rewolucjonista, op. cit., p. 192.

90 Basil the Great, The Morals 70,1-37: PG 31, 816-845; ŹM 5, tłum. J. Naumowicz, Kraków 1995, p. 200-223.

91 Basil the Great, The Morals 71,1-2: PG 31, 845; ŹM 5, 223-224.

92 Basil the Great, The Morals 72,1-5: PG 31, 845-849; ŹM 5, 224-227.

93 Basil the Great, The Morals 73,1-6: PG 31, 849-853; ŹM 5, 227-230.

94 Basil the Great, The Morals 74,1-2: PG 31, 853-856; ŹM 5, 230-231.

95 Basil the Great, The Morals 75,1-2: PG 31, 856-857; ŹM 5, 231-233.

96 Basil the Great, The Morals 76,1-2: PG 31, 857; ŹM 5, 233-234.

97 Basil the Great, The Morals 77,1: PG 31, 857; ŹM 5, 234-235.

98 Basil the Great, The Morals 78: PG 31, 857-860; ŹM 5, 235.

99 Basil the Great, The Morals 79,1-2: PG 31, 860; ŹM 5, 235-236. 
Salvation. ${ }^{100}$ This was obviously in an answer to the doctrine of disregard and non-valuation of the Sacraments to the benefit of the socalled mystical experience propagated by the radical Eustathians and later also by Messalians. ${ }^{101}$

In this historical context of the development of ascetic ideas in Asia Minor of the fourth century, there was a suitable place for St. Basil's teachings concerning voluntary poverty and the ascetic attitude towards private property. Saint Basil, in the Letter 223 addressed to Eustathius of Sebaste, written in 375 a.d. explicated personal motivation behind living in voluntary poverty. In it, we discern Basil's attempt to disprove the accusations spread by the Eustathians, who acted in a pestering way and tried to undermine their good reputation among the brothers. ${ }^{102} \mathrm{He}$ also provided his interpretation of poverty, when, referring to the text of Mt 19:21 and Acts 4:32-34, he invoked the beginnings of his ascetic experience. ${ }^{103}$

Personal justifications for Basil's choice of living in poverty were explicated in the Letter 223, written in 375 a.d. to Eustathius of Sebaste. In it, Basil wished to rebut the statements spread by Eustathians. They, according to Basil, rendered lives of others unpleasant and discredited them among the brothers. At the opportunity, he also drew up a commentary on the subject of poverty, where he referred to to Mt 19:21 and Acts 4:32-34 invoking the

100 J. Gribomont, Il prezioso sangue in Basilio, [in:] Sangue e antropologia biblica nella Patristica, a cura di F. Vattioni, Roma 1982, p. 413-431; C. Riggi, Ascetica e sangue in Basilio, [in:] Sangue e antropologia nella Liturgia, a cura di F. Vattioni, Roma 1984, p. 1125-1146; M. Girardi, Alleanza ed elezione. Il nuovo popolo di Dio, [in:] M. Girardi, Basilio di Cesarea interprete della Scrittura. Lessico, principi ermeneutici, prassi, Bari 1998, p. 199-208.

101 J. Gribomont, Święty Bazyli - ewangeliczny rewolucjonista, op. cit., p. 192.

102 Basil the Great, Letter 223, 1: PG 32, 820-824; PAX 16, 250.

103 As C. M. Paczkowski noticed, Egzegeza biblijna Bazylego Wielkiego, "Quaestiones selectae" 1 (1994), p. 29-41, when Bishop of Cappadocia referred to the Bible, he quoted a lot of its fragments all the same reducing his own comments to minimum. Such conduct had its own logic of explaining one part of the text with another, thus leaving space for meditation. 
150 The studies regarding monasticism and voluntary poverty...

beginnings of his ascetic life and concluded that the most efficient way to reach perfection is relinquishing the ownership, poverty community, disengagement of worldly concerns and preventing the soul from resorting to vanity. ${ }^{104}$ In his further comment, we find out that the unity with like-minded people - which he met in the ascetic communities of Alexandria and other parts of Egypt, Palestine, Celesyria and Mesopotamia ${ }^{105}$ - may encourage that sort of conduct. For Basil, the ascetic sacrifice of cenobites was the source of motivation to live the same sort of life, for, as he puts it, this sort of life proved the presence of the Passion in their bodies and all the same Basil hungered with all his might to be just like them. ${ }^{106}$ The ascetic motivation to renunciation of goods, so typical for radical Eustathians, did not bring forth the feeling of contempt for ownership in case of St. Basil. In the Letter 4 to Olympus, written in hermitage in Annisa between 358 and 365 a.d., Basil delivered a literary praise of poverty, quoting stoic protagonists of the philosophy of renunciation such as Zeno of Citium, Cleanthes of Assos and Diogenes of Sinope ${ }^{107}$ - the Cynic glorifier of renunciation. In Basil's ascetic reasoning, this constituted an exception, as Basil never referred to philosophical concepts nor classic authors in his recommendation of monastic life. ${ }^{108}$ The above-mentioned paragons of philosophy were important, but not the leading ones in his deliberations, which is evident in his reference to 1 Tim 6:8 and $\mathrm{Col} 3: 5$, in the Letter 22 On the perfection of monastic life, written in 364 a.d., at which point he recommended Christian moderation of earthly goods and avoidance of excess, which were to lead monks to fear of God (in accordance with Ps 118:120). ${ }^{109}$

\footnotetext{
104 Basil the Great, Letter 223, 2: PG 32, 824; PAX 16, 251.

105 Basil the Great, Letter 223, 2: PG 32, 824; PAX 16, 251.

106 Basil the Great, Letter 223, 2: PG 32, 824; PAX 16, 252.

107 Basil the Great, Letter 4: PG 32, 236-237; PAX 16, 42-44.

108 J. Gribomont, Les Règles épistolaires de saint Basile. Lettres 173 et 22, "Antonianum" 54 (1979), p. 255-287.

109 Basil the Great, Letter 22, 3: PG 32, 292-293; PAX 16, 63.
} 
One of the first Basilian norms concerning poverty (dating back to 360 a.d.) ${ }^{110}$ was Rule 31 of The Morals, which allowed the Church to use private possession. ${ }^{11}$ Basil referred to Mk 7:26-29 (A Syrophoenician Woman Meets Jesus) in the attempt to substantiate his thesis with the Bible. This was motivated by the need to conform to Basil's ascetic rhetoric and did not get out of the logic of the text Mk 7:26-29.112

According to Basil, the goods sacrificed to God and Church goods should not be used for other purposes unless they were in excess. When he came out in favour of the Church using the goods sacrificed to God he might have been under the impression of the ascetic dispute between the two leaders of the Eustathians; one of them being Eustathius himself - who supported using the Church property charitably - and the other one Aerius - the radical one who rejected the idea of using property). ${ }^{113}$

We may read in the Rule 32 of The Morals that what one should be given what belongs to them. ${ }^{114}$ To substantiate this rule, Basil referred to Lk 20:21-25 (obligations towards the emperor and God), and to Rom 13:17 (paying taxes, respecting superior-subordinate relationship). The Rules 31 and 32 constitute a profile of certain social relationships in administering goods by Christians. After Church goods (Rule 31), Basil referred to state goods, such as taxes

110 J. Gribomont, Histoire du text des Ascétiques de saint Basile, Louvain 1953, p. 257; R. Pouchet, Basile le Grand et son univers d'amis, op. cit., p. 179.

111 Basil the Great, The Morals 31a: PG 31, 749; English transl.: "That objects set aside for those consecrated to God should not be usurped for others' use unless there be something superfluous." http://pl.scribd.com/doc/39117668/St-Basil-the-Great-Ascetical-works.

112 Basil the Great, The Morals 31b: PG 31, 749; English transl.: "Or the woman was a Gentile, a Syro-phoenician born. And she besought him that he would cast forth the devilout of her daughter. Who said: Suffer first the children to be filled; for it is not good to take the bread of the children, and cast it to the dogs. But she answered and said to him: Yea, Lord; for the whelps also eat under the table of the crumbs of the children. And he said to her: For this saying go thy way, the devil is gone out of thy daughter.” http://pl.scribd.com/ doc/39117668/St-Basil-the-Great-Ascetical-works.

113 J. Gribomont, Święty Bazyli - ewangeliczny rewolucjonista, op. cit., p. 193.

114 Basil the Great, The Morals 32: PG 31, 749; ŹM 5, 145. 
152 The studies regarding monasticism and voluntary poverty...

and clerical relations calling his monks to act in accordance with the Bible. ${ }^{115}$ There was no place for contesting and denying national structures as the Eustathians had done. Basil obliged the monks to comply with basic social obligations.

In The Morals 47 and 48 Basil presented the way he perceived the asceticism of voluntary poverty. Rule 47 shows that Basil was convinced that suppressing material needs voluntarily should follow the Evangelical call to amass wealth for yourself in Heaven rather than on the Earth. ${ }^{116}$ Basil found justification in the texts of Mt 6:19, Lk 12:33, Lk 18:22 and 1 Tim 6:18. The decision to undertake life in poverty may not hem the monk in. "They should be compassionate and generous, for they who are not such are denounced". ${ }^{117}$ According to Basil, we may find Biblical confirmation of such code of conduct in Mt 5:7, Lk 6:30, Rom 1:31 and Tim 6:18. The monk should content himself with what is necessary for living and give the rest to charity. ${ }^{118}$ The New Testament motivation given by Basil may be found in the texts of Lk 3:11 and 1 Cor 4:7 and 2 Cor 8:14.

Therefore, one should not be rich, but poor ${ }^{119}$ and "should not be eager to have the necessities of life in abundance, nor seek after luxury or satiety; but we should be free from every form of avarice and ostentation". ${ }^{120}$ The monk "should [not] be anxious on account

115 J. Gribomont, Święty Bazyli - ewangeliczny rewolucjonista, op. cit., p. 193.

116 Basil the Great, The Morals 47: PG 31, 768; English transl.: "That one ought not lay up treasure for himself on earth but in heaven; and the method to be followed in laying up treasure in heaven." http://pl.scribd.com/doc/39117668/St-Basil-the-GreatAscetical-works.

117 Basil the Great, The Morals 48:1: PG 31, 768; ŹM 5, 160.

118 Basil the Great, The Morals 48:2: PG 31, 768; English transl.: "That whatever the man may possess over and above what is necessary for life, he is obliged to do good with, according to the command of the Lord who has bestowed on us the things we possess." http:// pl.scribd.com/doc/39117668/St-Basil-the-Great-Ascetical-works.

119 Basil the Great, The Morals 48:3: PG 31, 769; ŹM 5, 161; according to Basil, Biblical justification may be found in Lk 6:20-24; 2 Cor 8:2; 1 Tim 6:9.

120 Basil the Great, The Morals 48:4: PG 31, 769; ŹM 5, 162; he referred to Lk 12:5 and $1 \operatorname{Tim} 6: 8$. 
of his own need, nor place his hope in the appurtenances of this life, but commend his affairs to God." ${ }^{21}$ Monks should take care of their brethren life's needs, ${ }^{122}$ catering to their own biological and charitable needs through work. ${ }^{123}$

The Asketikon of St Basil the Great dates back to the year 377 the time of Coenobitism at its best. The Greater Asketikon consists of Greater and Lesser Rules. ${ }^{124}$. In the Greater Rule 8, Basil depicted what it means to live in accordance with God, and hence in accordance with ascetic values; he showed that Jesus Christ promoted renouncement (cp. Mt 16:24 and Lk 14:33) ${ }^{125}$. Basil stretched this invitation over other matters - ascetic renunciation of material goods among them. "But, a beginning is made by detaching oneself from all external goods: property, vainglory, life in society, useless desires, after the example of the Lord's holy disciples." 126

According to St Basil, the renouncement of the above made sense only for a person who was "strongly seized with the desire of following Christ [such a person] can no longer be concerned with anything pertaining to this life." 127 In this context, what seemed crucial was Jesus calling to follow Him and the provided argumentation (cf. Lk 14:33 and Mk 19:21). ${ }^{128}$ For the sacrifice the ascetic was supposed to acquire a pearl and "the precious pearl is meant to

121 Basil the Great, The Morals 48:5: PG 31, 769.772; ŹM 5, 162; Biblical reference: Mt 6:24-34; Lk 12:16-19 and 1 Tim 6:17.

122 Basil the Great, The Morals 48:6: PG 31, 772; English transl.: "That he who is able should work and give to those in need.” http://pl.scribd.com/doc/39117668/St-Basil-theGreat-Ascetical-works.

123 Basil the Great, The Morals 48:7: PG 31, 772.773; ŹM 5, 164, Biblical reference: Mt 10:10; Acts 20:35; Eph 4:28 i 2 Thess 3:10.

124 J. Gribomont, Histoire du texte, op. cit., p. 13-14, 205-207.

125 Basil the Great, The Greater Rules 8,1: ŹM 6. Basil the Great, Pisma ascetyczne, t. 2, tłum. J. Naumowicz, Kraków 1995, p. 81.

126 Basil the Great, The Greater Rules 8:1: http://pl.scribd.com/doc/39117668/St-Basilthe-Great-Ascetical-works.

127 Basil the Great, The Greater Rules 8:2: http://pl.scribd.com/doc/39117668/St-Basilthe-Great-Ascetical-works.

128 Basil the Great, The Greater Rules 8:2: http://pl.scribd.com/doc/39117668/St-Basilthe-Great-Ascetical-works. 
154 The studies regarding monasticism and voluntary poverty...

be an image of the heavenly kingdom," "t29 "the transference of the human heart to a heavenly mode of life." 130 This earthly renouncement was the beginning of our assimilation with Jesus who "was rich, yet for your sakes he became poor, so that by his poverty you might become rich" (2 Cor 8:9). If we did not reach the assimilation, we would not be able to live in accordance with the Gospel. ${ }^{131}$ Through renouncing passion and pleasure, voluntary poverty became a means to reach a homogenous Christian life (cp. Ps 67:7), the sole objective of which was to glorify God. ${ }^{132}$ According to Basil, the poor in spirit (Mt 5:3) are those who became so due to Christ's teachings and accepted their state thanks to acting in God's will. ${ }^{133}$ The monk was not supposed to feel ashamed of poverty in the name of Jesus, ${ }^{134}$ as being poor now meant that in the life to come he would receive solace. ${ }^{135}$

For Christ, wealth was in opposition to poverty. For some rich men, who considered pleasure to be the paramount of well-being, the wealth became a means to reach pleasure and was virtually considered the topmost good. ${ }^{136}$ For Basil, living in wealth for pleasure was a form of idolatry, involvement in passion, a virtual,

129 Basil the Great, The Greater Rules 8:2: http://pl.scribd.com/doc/39117668/St-Basilthe-Great-Ascetical-works.

130 Basil the Great, The Greater Rules 8:3: http://pl.scribd.com/doc/39117668/St-Basilthe-Great-Ascetical-works.

131 Basil the Great, The Greater Rules 8:3: PG 31, 940.941; ŹM 6, 86.

132 Basil the Great, The Greater Rules 20:2: PG 31, 973; (cf. 1 Cor 10:31; 2 Cor 2:17). English transl.: "The life of the Christian does not vary, inasmuch as its end - the glory of God - is ever the same; for Paul says, speaking in Christ: 'whether you eat or drink or whatsoever else you do, do all to the glory of God.' 'The life of persons in the world, on the contrary, is complex and varied, adapting itself in diverse ways to gratifying the whims of every chance acquaintance." http://pl.scribd.com/doc/39117668/St-Basil-the-Great-Ascetical-works.

133 Basil the Great, The Greater Rules 205: PG 31, 1217; ŹM 6, 356-357 (cf. Mt 19:21; Lk 16:20-22).

134 Basil the Great, The Greater Rules 20:2: PG 31, 972.973; ŹM 6, 112.

135 Basil the Great, The Lesser Rules 181: PG 31, 1204; ŹM 6, 341 (cf. Mt 25:42; Lk 16:22-25).

136 Basil the Great, The Greater Rules 20:2: PG 31, 972, 973; ŹM 6, 112. 
heterogeneous life. Ultimately, living in wealth was not glorifying God. ${ }^{137}$

Renouncing earthly goods, material ones among them, was in Basil's mind the price for ascetic acquisition of the heavens and imitating Christ. For the ascetic, the preoccupation with earthly concerns and material goods constituted a threat to the development of evangelical assimilation with Christ. Therefore, the ascetic could not give in to coveting what is necessary, especially of material value. ${ }^{138}$

However, Basil highlighted that renouncing earthly goods should be effected scrupulously, preferably personally and if not, then by a trusted person who handles goods wisely and accurately. ${ }^{139}$ Basil specifies that a local bishop is such a person. ${ }^{140}$ All that was needed to avoid unnecessary court appearance and so that "We must everywhere be on our guard lest, under pretext of observing one commandment we break another." 141

In the late teachings on poverty of St Basil the Great known from Greater and Lesser Asketikon, we may discern references to a specific, however not unique or exclusive, model of Christian voluntary poverty, which, following Jean Gribomont, has nowadays been described as an ascetic form of renouncing personal property in the name of creating a form of Christian social communism. ${ }^{142}$

137 Basil the Great, The Greater Rules 20:2: PG 31, 972-973; ŹM 6, 112-113; cf. Lk 16:2225; Gal 2:18; Rom 2:1; 1 Cor 10:31; 2 Cor 2:17.

138 Basil the Great, The Greater Rules 8,3: PG 31, 940.941; ŹM 6, 86.

139 Basil the Great, The Greater Rules 9:1: PG 31, 941; ŹM 6, 87.

140 Basil the Great, The Lesser Rules 187: 1208; Polish transl.: "Dlatego niech te dobra zostaną oddane temu, komu powierzono troskę o Kościoły w różnych miejscach, jeśli jest on obdarzony zaufaniem i zdolny zarządzać rozsądnie. W ten sposób będziemy naśladować tych, o których mówią dzieje, że przynosili to, co mieli i składali je u stóp Apostołów”: ŹM 6, 346 (cf. Acts 4:35).

141 Basil the Great, The Greater Rules 9:2: PG 31, 941.944; ŹM 6, 87.

142 J. Gribomont, Povertà, [in:] Dizionario degli Istituti di Perfezione, vol. 7, a cura di G. Rocca, Roma 1983, p. 246-248. 
The studies regarding monasticism and voluntary poverty...

This Coenobitic ideal, propelled by a utopian and charismatic vision of the Christian community, was drawn from Acts 2:44-45..$^{143}$

It seems though that for Basil the most important was not Luke's concept of a pefect community but the argumentation and Jesus himself urging renunciation and calling to follow Him. The monk reached the Heavens during his earthly voyage upon giving up material goods and following Christ in His renunciation and becoming poor in spirit.

\section{Conclusion}

Two aspects of the ascetic doctrine of St Basil the Great concerning the subject of monastic poverty may be methodologically distinguished; a critical anti-Eustathian and a positive one - a lecture on voluntary poverty. The former visible in The Letters and The Morals, the latter in the late works of Basil, namely Greater and Lesser Asketikon - a more positive lecture on Basil's thoughts on asceticism.

Basil's critical approach to false asceticism, especially by radical Eustathians, becomes clearer when Basil's earlier works (up to 365) is compared with historical documents concerning Eustathians. From those, we learn that the radical Eustathian movement postulated contempt towards corporeality and the ideal of absolute renunciation of material goods.

The Synod in Gangra (340), condemned the Eustathians' heterodox views who, in terms of social issues, condemned marriage

\footnotetext{
143 Basil the Great in his ascetic works refers to Acts 2:44 five times (The Greater Rules 7:3; 32:1; 35:3, The Lesser Rules 85; 183); whereas to Acts 4:35 - eight times (The Greater Rules 19:1; 34:1, The Lesser Rules 93; 131; 135; 148; 187; 252) in the context of perfect brotherly community in faith; they assist and support one another with the virtues of others. For more cf. Clara Burini, La comunione e "distribuzione dei beni" di Atti II,44 e IV,32.35 nelle Regole Monastiche di Basilio Magno, "Benedictina” 28 (1981), p. $151-169$.
} 
and elevated virginity. What is more, it rejected their non-canonical way of fasting, the ascetic contempt of meat, their contempt of fairly acquired material goods and the Eustathian approval of slaves escaping others to join them.

The Synod also stigmatized the eristic and non-Christian Eustathian argumentation, which invalidly referred to denying salvation to those, who thought and acted differently than the members of the Eustathian movement.

The Canons of Gangra had been integrated in the Byzantine legislature and Decretum Gratiani - a western law collection. A significant silence on the part of St Basil in relation to the Canons of the Synod of Gangra might have been motivated with the hypothesis that Bishop of Kaisareia in Cappadocia did not refer to it due to the fact that the decisions had been made by Arian bishops.

In Basil's works, especially The Morals 70-79, a line of synodic recommendations is already visible. It relates to the essence of true asceticism consistent with the teaching of Church and the anti-Eustathian (though Arian) instructions of the Synod of Gangra.

As an Asia-Minor monastic reformer, Basil indirectly followed the example of Eustathius of Sebaste - the master of spiritual life and propagator of charitable activities. However, having Eustathius for a master did not result in Basil's scornful approach towards neither private property nor justly rich people. In The Morals 31, Basil justified the usage of private property by the Church and called monks to share basic social responsibilities such as tax payment or respecting the state structure - including slavery.

In The Morals 47-48 he outlined the first ascetic model of voluntary poverty - in his opinion an immediate result of the Evangelical call to amass wealth in heaven, not on earth.

The Basilian doctrine of poverty sketched in Greater Asketikon was a positive, not polemical, lecture on ascetic study of the monastic renunciation of corporeal goods in the hope of receiving a prize in Heaven. Voluntary poverty was not an ultimate means, but was 
The studies regarding monasticism and voluntary poverty...

supposed to serve as a means to reaching a homogenous Christian life filled with glorifying God and achieving Salvation.

The decision about initiating the life of renunciation should be sensible, just as all things devoted to God should. According to Basil, Jesus' advice given to a young rich man described in Mt 19:21 did not imply total deprivation, but sensible handing out goods to the needy - preferably through a bishop. A Basilian monk achieved poverty through renouncing things that were superfluous in order to control his desires - especially those of corporal nature - on his way to entrust them to God. 


\section{VII}

\section{An analysis of the issues related to the virtue of poverty in the Western Church at the beginning of the sixth century. The case of the Rule of the Master (Regula Magistri) $^{144}$}

The teachings of the Western Church in the fifth century were characterised by two fundamental positions regarding the issue of possession, wealth and poverty: realistic and pessimistic. The realistic perspective postulated by the Church Fathers promoted the fair acquisition, possession and use of material goods. This model was offered to all Christians. The pessimistic perspective propagated the ascetic approach to property and it was recommended only to the chosen ones. According to monks and ascetics, material goods, though created by God, were the source of constant temptations and vices, in particular of greed and idolatry. The model that was quite popular in the Western Church of the fifth century was Coenobitic monasticism. For Coenobites, individual possession was forbidden and monastery goods were shared in common. According to Coenobites, material goods should be scorned, renounced and used

144 This article was originally published under the title: Problematyka cnoty ubóstwa w Kościele zachodnim początków VI wieku na przykładzie tzw. Reguły Mistrza (Regula Magistri), “Analecta Cracoviensia” 41 (2009), p. 175-188. 
160 The studies regarding monasticism and voluntary poverty...

as little as possible. In the sixth century, Coenobitic monasticism practically dominated forms of monastic life in the Western Church.

Did such dominance of Coenobitism have a significant impact on a Christian attitude towards worldly possessions? It seems it did, as the realistic model of fair acquisition, possessions and use of wealth vanished for many centuries. The approach towards property that dominated western Christianity was based on the monastic ideology that was ascetic and pessimistic in its expression. This chapter examines monastic poverty in The Rule of the Master which was one of the most important texts for the western monasticism of the sixth century. The Rule of the Master greatly influenced The Rule of St. Benedict, thus having an effect on understanding poverty in the late Christian Antiquity.

\section{Preliminary issues concerning the virtue of poverty in the Rule of the Master}

Regula Magistri (The Rule of the Master) which dealt with the issues of material possession and considered poverty as a virtue was one of the most crucial monastic documents dating back to the beginning of the sixth century. The text was composed in the Rome area at the beginning of the sixth century. Adalbert de Vogüé, OSB, who examines the chronological and formal interrelations between The Rule of St. Benedict and The Rule of the Master provides in his numerous research projects arguments that clearly point to such dating and such a place of origin of the Rule of the Master. ${ }^{145}$ The

145 A. de Vogüe, Introduction, [The Rule of the Master]. A de Vogüe OSB claims that "the date we propose is confirmed in some measure by certain indications of the liturgical cycle: the existence of Prime and Sexagesima, a commentary on the psalms within a baptismal context, a system of two readings from the New Testament at Mass, and thus custom of not signalling alleluia outside Paschal time. Here [...] we have characteristics that are best situated in the surroundings of Rome and Campania in the course of the first decades of the sixth century", 75. For more see: A. de Vogüe, The Master and Benedict. A Reply to 
Rule of the Master was most probably introduced in at least one monastery where i author was an abbot. ${ }^{146}$ There are, however, other views on the place of origin of the rule. According to François Masai ${ }^{147}$ and Eugene Manning, ${ }^{148}$ for instance, the rule was composed at the beginning of the sixth century in Gallia, probably in the monastery on the Lérins island. Others researchers locate it in Bobbio in northern Italy. ${ }^{149}$

Poverty as a virtue was promised by candidates to monkhood before the proper vows of conversion of manners and stability of conversion were made. It did not mean, however, that the monastery itself was poor. Its financial matters were regulated by the monastic ideology. According to The Rule of The Master, the monastery owned lands that were leased to immigrant workers by a lay

Marilyn Dunn, “The English Historical Review” 107 (1992), p. 95-103; A. de Vogüe, Faut-il mettre le Maitre en enfer?, "Collectanea Cisterciensia” 57 (1995), p. 132-148; A. de Vogüe, La Maitrise litter aire du Maitre d'apres une itude recente, "Collectanes Cisterciensia” 58 (1996), p. 149-160; K. Zelser, Zu einigen Textproblemen der Regula Magistri, Textsorten und Textkritik, Österreichische Akademie der Wissenschaften, Philosophisch-Historische Klasse Sitzungsberichte 693, Veroffentlichungen der Kommission zur Herausgabe des Corpus der lateinischen Kirchenvater, Heft 21, Wien 2002, p. 231-242.

146 A. de Vogue, Introduction, SCh 106, 123.

147 H. Vanderhoven, F. Masai, Aux sources du monachisme benedict, [in:] La Regie du Maitre. Edition diplomatique des manuscrits Latins 12205 et 12634 de Paris, Bruxelles 1953 (Les publications de Scriptorium III); A. de Vogüe, Les recherches de Fr. Masai sur le Maitre et s. Benoit, "Studia Monastica” 24 (1982), p. 7-42, 271-301; A. Roth, Ursprung der Regula Magistri. Die Kontroverse zwischen F. Masai und Vogüe, "Erbe und Auftrag” 60 (1984) 2, p. 119-127.

148 E. Manning, Les Hapax Legomena dans la Regie du Maitre, "Archivum Latinitatis medii aevi” 33 (1963), p. 17-34; E. Manning, Problemes du monachisme benódictin primitif, "Revue d'Histoire de Spritualite" 48 (1972), p. 113-114; E. Manning, Rapports entre la Reguta Magistri et la Reguła Benedicti. Les deux plans, "Regulae Benedicti Studia” 1 (1972), p. 99110; E. Manning, A propos de quelques titres dans la Reguła Magistri, "Studia Monastica" 29 (1978), p. 7-15.

149 P. Blanchard, La Regie du Maitre et la Regie de saint Benoit, "Revue Benedictine" 60 (1950), p. 25-64; M. Tosi, La presenza della Regula Benedicti nel monastero di S. Colombano in Bobbio, "Ravennatensia" 9 (1981), p. 47-99; M. Dunn, Mastering Benedictine monastic rules and their authors in the early medieval West, "English Historical Review” 105 (1990), p. 567-594; M. Dunn, The Master and St. Benedict. A Rejoinder, "The English Historical Review” 197 (1992), p. 104-111. 
The studies regarding monasticism and voluntary poverty...

administrator on behalf of the monastery. ${ }^{150}$ The lay lessee was responsible for the entire administration of the monastery lands, ${ }^{151}$ which meant that monks did not have to worry about the maintenance and management of their property and instead could focus on observing the rules created by an anonymous master - the author of the monastic rule. ${ }^{152}$

Monks, as a corporation managed by the abbot, held material goods - lands administrated by the lay land agent, who took upon himself the difficulty of managing the agricultural property of the monastery and who gave an income, in a form of an "annual payment," to the abbot. ${ }^{153}$ The land administrator also took care of the quality of labour and he was in charge of hiring seasonal workers and employing coloni [i.e. tenants in Ancient Rome]. ${ }^{154}$ Monks, on the other hand, just took care of their monastic life, and did not take up any labour tasks, because "it is not when strength is subjected to fasting that there should be discussion about whether a man ought to work more for his stomach than for his soul and God. Wherefore let the crafts alone together with the garden suffice as work in monastery." ${ }^{55}$ Thanks to a steady income, monks did not have to worry about earning their living which in turn enabled them to devote themselves to various spiritual and ascetic practices, including the practice of the virtue of poverty.

150 RM LXXXVI, 1-2: "All the lands of the monastery should be rented out so that a secular lessee is burdened with all the field work, the care of the estate, the clamors of the tenants, the quarrels with the neighbors" (Cistercian Publications, Michigan, 1977, 251).

151 RM LXXXVI, 14: "Therefore the lands of the monastery should be rented out so that a secular workman may be busy with secular matters, but then we, to whom priest cries out 'Lift up your heart,' and we assure him with the response: 'We have lifted it to our Lord,' we should not let it wander off in early thoughts", 252.

152 RM LXXXVI, 3-13, 251.

153 RM LXXXVI, 24: "It is therefore better to own them under someone else's management and to be sure of receiving annual rets, while we take care of nothing except our soul", 252.

$154 \quad$ RM LXXXVI, 2, 251.

155 RM LXXXVI, 26-27, 252. 


\section{General instructions regarding the virtue of poverty for the candidates beginning monastic life}

Monastic poverty was defined by the author of the Rule of the Master as a legal obligation applying to monks and stemming from the vow of stability. ${ }^{156}$ The author of the rule discussed the impoverished life in the very first chapter when he enumerated four types of monks: 1. Coenobites (Latin coenobiotrum) who lived in the monastery, and served under a rule and an abbot; ${ }^{157} 2$. Anchorites (Latin anachoritarum) who were hermits (Latin heremitarum); ${ }^{158}$ 3. Sarabaites (Latin sarabaitarum), who were, according to the author, a despicable type of monks who could be considered lay people if not for their tonsure that indicated the holy way of life; ${ }^{159}$ 4. Gyrovagues (Latin gyrouagorum, so called wandering monks), whom the author rather passed over in silence. ${ }^{160}$ When talking about Gyrovagues, he juxtaposed the hospitability of an impoverished monk and the hypocrisy of wandering monks.

And if, not far from this monastery, they find a monk's cell, they stop there, saying they have come from far-off Italy. With head bowed as if in humility, they lie again about pilgrimage and captivity to this new host, forcing the good man out of the sympathy for their long journey to use up his whole scanty means in cooking and serving them food, most certainly only to be left destitute and plundered by these gluttons after a couple of days. When the next day he himself, his cell, his customs and rule of life does not please them, and when after two days he, like the others, reduces the fare, he too is soon driven to give them back

\footnotetext{
156 A. de Vogüé, Povertà, [in:] Dizionario degli Istituti di perfezione, vol. 7, a cura di G. Rocca, Roma 1983, p. 267.

157 The Rule of the Master I, 1, 105.

158 The Rule of the Master I, 3-5, 105.

159 The Rule of the Master I, 6, 105.

160 The Rule of the Master I, 13,106.
} 
164 The studies regarding monasticism and voluntary poverty...

their pouches which have already been filled with bread baked and given them by various hosts. Although the bread is fresh when they take it from the table in the various hostels, they cause it by their avarice to become mouldy by hoarding it. ${ }^{161}$

Itinerant monks scrounged food off their well-meaning host until they got bored with their host and his way of life. The author of he Rule of the Master used a characteristic expression to describe their attitude, saying that faking modesty and humility they stayed with their host to "use up his whole scanty means" (RM I, 38). It is worth noticing that poverty was therefore a way of life understood as a form of modest and conditional possession and use of material goods which were available to a monk. A monk was provided with a place to live, food and means to host brothers, even so called wandering monks.

Consecrated poverty was therefore, according to the anonymous author of the Rule of the Master, one of the basic aspects of monastic life. In order to become a monk, a candidate - if he did not get discouraged by the preliminary trial - listened to the text of the rule that was explained by an abbot. ${ }^{162}$ The candidate promised to follow the presrciptions of the rule. ${ }^{163}$ Then, the abbot spoke to the candidate about the renunciation of earthly goods.

let the abbot then go on, saying: "What about your possessions which you have liberty of using? It is not expedient for you to be settled here for the sake of God while your possessions remain elsewhere. Rather, as Scriptures say: 'Let your treasure too be there where your heart is." It is nor expedient because, through your craving for them, your possessions located outside might possibly entice you, seduced by the devil, out of the

\footnotetext{
161 The Rule of the Master I, 36-43, 107-108.

162 The Rule of the Master LXXXVII, 2, 253.

163 The Rule of the Master LXXXVII, 2-5, 253.
} 
monastery. Then having deserted from service in the holy school you will go back to do service according to your own will and be pleased to return like a dog to your own vomit, and reswallow with dirt the spittle you had spit out on the ground. But because perseverance wants to remain oblivious of any chance to go elsewhere, we offer the salutary advice that you listen instead to the voice of the Lord saying to you: "Go, sell everything and give to the poor, and come, follow me. So if you wish to comply with the voice, go, sell what you have and bring here to me the entire sum received, so that in your presence I may distribute it to the poor and you may have nothing left as a pledge to the word to go back to it again. It is indeed for this very reason that as long as your admission into the monastery has not been made permanent, you are still allowed free disposition of your possessions, because after admission has been made permanent, a disciple is forbidden by the Rule to have anything of his own whether in the monastery or out of it, so that they may be no occasion for his self-will to assert itself."164

The candidate was supposed to sell his goods and bring the money to the abbot who gave it to the poor on the candidate's behalf, which guaranteed that the candidate was unable to revert to his previous lifestyle which he had renounced. The sale of all possessions and the distribution of property among the poor were unconditional. It was checked whether the candidate had indeed got rid of all his property and only when it was verified that he had renounced all earthly goods was he admitted to the monastery. ${ }^{165}$

164 The Rule of the Master LXXXVII, 5-18, 253-254.

165 The Rule of the Master LXXXVII, 41-48: "As to a brother who declares that he has nothing at all, first let inquiry be made of the neighbors in the area where he lived, and if his poverty is found to be really total, then let him give a guaranty of perseverance, with the penalty stipulated at the end of the document, provided of course that he is known by this time. Only then should he be received into the monastery, because otherwise it may turn out that he has stored some of his things outside for a time, feigning poverty in the monastery, 
The studies regarding monasticism and voluntary poverty...

The candidate was not allowed to take the precaution of reserving any wealth to himself in case he wanted to return to the world. ${ }^{166}$

The renunciation of material goods was supposed to be carried out according to the established form: the renunciation of property should be recognised as the candidate's choice in accordance to the will of God, whereas the distribution of goods of the one who joined the monastery was supposed to be mediated by the abbot. ${ }^{167}$ After these preliminary acts, the candidate took the vow of poverty.

if he firmly resolves to sell everything and not reserve anything for the monastery [...] so then, when he distributed everything through the hands of the abbot and then wishes to become a permanent member of the monastery, let no document of perseverance be demanded of him [...] let him merely give his word that nothing at all remains hidden away from him outside. ${ }^{168}$

Such vows were also the way in which the monastery protected their own possessions as the candidates were encouraged to sign in the presence of witnesses a special document saying that if they wanted to leave a monastery, they would do so without any material goods or reconciliation with God. ${ }^{169}$ Basil the Great recommend-

and not only does he give nothing to God as alms or to the monastery as a gift, but he also leaves for any reason that suits him, enticed by his possessions waiting for him outside. For only when he has provided the safeguard of a guaranty with a penalty may the goods of the monastery or purchase funds and draft animals be safely and without suspicion entrusted to him for monastery business", 255-256.

166 The Rule of the Master LXXXVII, 19-24, 254.

167 The Rule of the Master LXXXVII, 25: "If after the new brother has heard all this, in accordance with the first divine proposal he sells everything and distributes it through the hands of the abbot," 254.

168 The Rule of the Master LXXXVII, 26.28.31, 254-255.

169 The Rule of the Master LXXXVII, 35-37: "let him first with his own hand draw up a pledge of stability, adding an inventory of his goods. Then let him offer every thing with his soul as a gift to God and to the oratory of the monastery, with religious persons - bishop, priest and deacon, and the clergy of the area - signing as witnesses. In the document itself let him make this declaration, that should he ever want to quit the monastery he will depart from the monastery without his goods and from God without forgiveness of his sins," 255. 
ed a similar way of official taking the vows in the presence of two or three witnesses and the monastic superior when he was discussing the vows of chastity (that is the vow not to marry and to remain sexually pure). ${ }^{170}$ In this way, those who made monastic profession according to the Rule of the Master or Basil's Greater Rules could not legally cancel it. Moreover, if they did not want to carry on with the monastic life, they were to be exempted from vows in the presence of the same witnesses.

When the candidate was leaving the monastery, the Rule of the Master commanded him to promise to the abbot that he had not taken any monastic possessions. He was also obliged to return all things that he had been using in the monastery, "unless the abbot out of kindness wishe[d] to give him something," "I71 "In any case let him give back to the abbot the clothing and shoes that belong to the monastery, so that what is taken from those who depart may benefit a brother who perseveres, and that one who lives in the monastery may, as is right, have the things that belong to the monastery, whereas they are justifiable taken back from one who unjustifiably withdraws his heart from perseverance in the monastery."172

Similar instructions were directed to the candidates of noble status. The anonymous author did, however, take into consideration a feudal masters' potentially disapproving response to the fact that their sons had joined the monastery and as result his instructions towards the noblemen were more cautious and less rigorous than towards the candidates of gentry origin. After the preliminary promise of obedience to the abbot, ${ }^{173}$ the monastery verified the parents' reaction to the news that their son had entered the monastery. ${ }^{174}$ If

\footnotetext{
170 Basil the Great, Regulae fusius 15: PG 956.957; transl.: Greater Rules, 15, 4, ŹM 2: Św. Bazyli Wielki, Pisma ascetyczne, t. 2: Reguły dłuższe, Reguły krótsze, red. i tłum. J. Naumowicz, Kraków 1995, p. 98-99; see also: Mt 18:16.

171 The Rule of the Master LXXXVII, 53, 256.

172 The Rule of the Master LXXXVII, 55-58, 256.

173 The Rule of the Master XCI, 1, 267.

174 The Rule of the Master XCI, 2-7, 267.
} 
168 The studies regarding monasticism and voluntary poverty...

the parents supported their son, who remained under their care, ${ }^{175}$ in his decision to enter the monastery, they could choose between three options suggested by the creator of the Rule of the Master. First, they could give their son carte blanche to sell his part of the property. ${ }^{176}$ Second, they could divide the property that was his due into three equal parts: one part was to be distributed among the poor by the abbot on the candidate's behalf; the second part was left to the candidate's family in a form of a legal donation; and the third one was given to the monastery as a dowry "to be used for the benefit of the saints." ${ }^{177}$ Finally, if the parents of the son joining the monastery wanted neither to divide their son's property nor to give him any of his material goods, they had to formally disinherit him. ${ }^{178}$

Thus, material possessions of the monastery were secured whereas a monk who withdrew from the monastery was left with nothing to live on. Moreover, the author of the Rule of the Master deployed very demagogical arguments towards such a monk declaring that a monk withdrawing from the monastery was leaving it without reconciliation with God. Such intimidation of monks who wanted to leave the monastery did not appear for the first time in the Rule of the Master but was typical of the earlier rules as well. For instance, according to St. Basil's Greater and Lesser Monastic Rules, monks who took the vows and thus committed themselves to follow the precepts of the rule, were not allowed to withdraw from the monastery voluntarily, because their withdrawal was regarded as a sacrilege, a sin against God. Basil forbade his monks to get in touch or host such ex-monks, because he considered them as undisciplined Christians and wanted them to feel embarrassed. ${ }^{179}$ If intimidation did not help and a given monk

\footnotetext{
175 The Rule of the Master XCI, 45, 270.

176 The Rule of the Master XCI, 43-47, 269-270.

177 The Rule of the Master XCI, 52, 270. See also: The Rule of the Master XCI, 48$54,270$.

178 The Rule of the Master XCI, 55-69, 270-271.

179 Basil the Great, Regulae fusius 14: PG 31, 950-951; Reguly dhuższe [Greater Rules] 14: ŹM 6, 94-95 (cf. 2 Tes 3:14).
} 
insisted on leaving the monastery, he was to be treated by others as a stranger and a spiritual "blind man." 180 St' Basil's monastic rules were translated into Latin by Rufinus of Aquileia around $397 \mathrm{AD}$ and undoubtedly had an impact on shaping such western monastic rules as Augustine of Hippo's Ordo monasterii, Cassian's Institutiones, the Rules of Columbanus of Bobbio. ${ }^{181}$ The second Rule of the Father of Lérins ${ }^{182}$ composed around $427 \mathrm{AD}$ recommended a similar treatment of monks who wanted to leave the monastery. The Rule of St. Benedict clearly referred to previous monastic texts: John Cassian's Collationes Patrum i Institutiones and St. Basil's rules. ${ }^{183}$

\section{Poverty as a precondition accepted during the vows of monastic stability}

The aforementioned renunciation of material possessions and promise to observe poverty made by all candidates ( $R M$ LXXXVII) as well as the renunciation of goods by noblemen ( $R M \mathrm{XCI})$ were

180 Basil the Great, Regulae brevius 102: PG 31, 1153; Reguty krótsze [Lesser Rules] 102: ŹM 6, 288-289 (see Mt 15:13).

181 For more information on the impact of the early rules on the later ones see: G. Penco, Cromazio d'Aquileia e la "Regula Magistri”, "Revue Bénédictine” 81 (1971), p. 309-310; A. De Vogüé, Un écho de Césaire d'Arles dans la Règle du Maître, le Chrysostome latin et la "Passio Iuliani”, "Revue Bénédictine" 90 (1980), p. 288-289; M. Tosi, La presenza della RB nel monastero di San Columbano in Bobbio, "Ravennatensia" 9 (1981), p. 47-99; M. Dunn, Mastering Benedict. Monastic rules and their authors in the Early Medieval West, "The English Historical Review" 105 (1990), p. 567-594.

182 Statvta Patrum VII, 44-46: SCh 297, ed. A. De Vogüé, Paris 1982, 282; Polish transl: II Reguła Ojców: ŹM 3, tłum. K. Bielawski, wstęp J. Piłat, red. M. Starowieyski, Kraków 1994, p. 55 .

183 St. Bendict, Rule 73, 5: "Necnon et Collationes Patrum et Instituta et Vitas forum, sed et Regula Santi Patris nostri Basilii, quid Alid sunt nisi bene viventium et oboe dientium monachorum instrumenta virtutum?": Latin text according to the code 914 of the library in the St. Gallen abbey (IX w.), tłum. A. Świderkówna, Tyniec, Kraków 2005, p. 245-247; "So, too, the collations of the Fathers, and their institutes and lives, and the rule of our holy Father, Basil - what are they but the monuments of the virtues of exemplary and obedient monks?.” http://www.ccel.org/ccel/benedict/rule2/files/rule2.html. 
The studies regarding monasticism and voluntary poverty...

preliminary preconditions without which the vows of stability (first for two months ${ }^{184}$ and then for the whole life) could not be taken. If the candidate decided after two months not to continue the monastic form of living, he could leave the monastery either reconciled with the brothers (in which case he was given food, a lantern and an opportunity to give the sign of peace to all the members of the abbey) or like a guest - without the sign of peace, in which case he was treated by monks as a citizen of the devil, and not as the guest of Christ. ${ }^{185}$

Those who completed the preliminary trial of two months first promised to follow the rule for the rest of their lives, ${ }^{186}$ and then made formal profession in the presence of the abbot and the congregation of monks, ${ }^{187}$ which usually involved a donation of material goods to the monastery:

184 The Rule of the Master LXXXVIII, 1-5: "When there has been presented to the new brother by the Rule through the abbot all the foregoing about committing himself to stability, whether by disposing of his possessions as alms or as a gift to the monastery, or by a document of guaranty under penalty or, if he is unknown, by a sworn promise, let such still be granted a period of two months to deliberate with themselves, meanwhile working with the brothers, content with the common measure of food and the discipline of excommunications according to the Rule, so that such a one may make a trial of the monastery's way of life and himself be tested by the monastery," 257.

185 The Rule of the Master LXXXVIII, 11-13: "Then if at the end of the two months they are dissatisfied with the discipline and with those who are at the monastery and would like to go, let it be with the knowledge of the abbot and of everyone else. After giving his word that he has committed no theft and returning what monastery belongings he may have received for temporary use, let him next give the sign of peace to everyone and then receive a staff into his hands and provisions for the road. After a prayer, a verse is said and then the sign of peace is given to him. If he wishes it, let him depart as a guest, and let the devil reclaim this citizen of his, whom Christ unwillingly received as a guest," 257-258.

186 The Rule of the Master LXXXIX, 1-2: "If the discipline pleases them and they instead choose stability after completing the two months' delay for deliberation, and would like to commit themselves to perseverance after having promised anew their steadfast adherence to the Rule read to them, let the abbot again question the new brother to learn what he has decided during the period of delay granted him. To his response that he promises to practice obedience in all things, the abbot shall reply, 'Thanks be to God."'

187 The Rule of the Master LXXXIX, 3-16, 258-259. 
After these words, if he is entering with his possessions, the donor himself with his own hand then places upon the altar the inventory of his possessions and the deed of their donation to God through the monastery. While so doing, the brother says: "Behold, Lord, whatever you have given me I am returning to you, offering it together with my soul and in my poverty, and I want my possessions to be there where my heart and my soul are, but in the power of the monastery and of the abbot whom you, Lord, are setting over me to fear as your representative, since you say to them: 'Any one who listens to you listens to me; anyone who rejects you, rejects me.' Consequently, because through him you keep our needs in mind, we ought to have nothing of our own, for you are our surety for everything and in all things you alone suffice. So from now on, for us to live is Christ himself and to die is gain." 188

The documents regarding donations that were made to the monastery as well as the list of monks who contributed some goods upon entering the monastery were kept by the abbot. These documents were attached to each abbot's will and passed on to his successor so that the right to the donated property was secured and so that it was easy to prove to a monk who wanted to leave the monastery that he had renounced his goods and therefore was no longer entitled to them. ${ }^{189}$

188 The Rule of the Master LXXXIX, 17-23, 259.

189 The Rule of the Master LXXXIX, 31-35: "As for the inventories of the donations made by the brothers, the abbot at the time of his death includes in his last will what is left over after expenditures for the needs of the monastery, as also the names of those whose gifts are recorded, so that after his death no one chancing to quit the monastery will have the effrontery to demand the return of his possessions, cutting short his stability in the monastery and breaking his word to the deceased, or claim that something belonging to him is being kept in the monastery without having been given to it," 260 . 
172 The studies regarding monasticism and voluntary poverty...

\section{The juridical dimension of poverty in the Rule of the Master}

The anonymous author of the Rule of the Master referred to the legal means with which he was familiar and which would guarantee that monks following his instructions would live in consecrated poverty. He wanted superiors of the monastery to employ all available legal means to ensure a total jurisdiction over the property of the monastery. Thus, he made sure that monks were deprived of the right to their property and were forbidden to retain anything they had been bequeathed. ${ }^{190}$

This tendency to regard the monastic virtue of poverty in legal terms and the right to interpret it given to the superior of the monastery can be clearly seen in $R M$ II, 48-51:

This is why we have said that all the brothers are to be called for the deliberation, according to the monastic maxim that the affairs of the monastery are the concern of all and not of any one person. Of all, because the brothers expect to go on replacing one another in the monastery in the course of time. Of no one person, because there is nothing in the monastery that any of the brothers can claim exclusively as his own, and no one determines or does anything by his own authority, but all live under the command of the abbot. The abbot is therefore the master of this holy art, not attributing the performance of it to himself but to the Lord, whose grace achieves in us whatever we do that is holy. ${ }^{191}$

A similar recommendation regarding deprivation of the right to property of all monks, except for the abbot, while simultaneously

\footnotetext{
190 A. de Vogüé, Povertà, op. cit., p. 267.

191 The Rule of the Master II, 48-51, 114.
} 
giving the abbot an authority over all possessions can be also encountered in $R M$ XVI, 57-61:

Let him receive all the utensils of the monastery and assign them to the various users. Of all the things in the monastery, let no one except the abbot regard anything as his own, whether it be something he has brought or found or made or acquired; let on one appropriate or keep anything exclusively for himself, because this is the intent of the rule: the goods of the monastery belong to everyone and to no one. ${ }^{192}$

As can be deduced from the quoted passages, according to the Rule of the Master, the abbot was the only legal owner of the monastery goods. He administered them and retained full control over them. He passed down his authority, which entitled him to manage the brothers, the monastery and its possessions, to the chosen successor in his will. ${ }^{193}$ The following passage regarding possession $R M 2,48$ - "the affairs of the monastery are the concern of all and not of any one person" ("res monasterii omnium est et nullius est") - seems to refer to the Roman civil law regarding corporate possession. ${ }^{194}$

192 The Rule of the Master XVI, 57-61, 164.

193 A. de Vogüé, Sub regula vel abbate, "Collectanea Cisterciensia” 33 (1971), p. 209241; A. de Vogüé, Le "De generibus monachorum” du Maître et de Benoît. Sa source - son auteur, "Regulae Benedicti Studia" 2 (1973), p. 1-25, especially pages 13-18; on the development of the specif discourse of power and authority of the monastic authorities in the subsequent versions of monasticism see the monograph: C. Leyser, Authority and ascetism from Augustine to Gregory the Great, Oxford 2000, p. 3-188.

194 M. P. Blecker, The civil rights of the Monk in Roman and Canon Law. The monk as servus, "American Benedictine Review" 17 (1966), p. 185-198; M. P. Blecker, Roman Law and "Consilium" in the "Regula Magistri" and the Rule of St. Benedict, "Speculum" 47 (1972), p. 1-28; J.-P. Devroey, “Ad Utilitatem Monasterii” mobiles et préoccupations de gestion dans l'économie monastique du monde franc, "Revue Bénédictine” 103 (1993), p. 224-240. 
174 The studies regarding monasticism and voluntary poverty...

\section{The spiritual dimension of poverty in the Rule of the Master}

Not only did the anonymous author of the Rule of the Master care for the legal obligations of monks to renounce property but, as A. de Vogüé notes, he simultaneously developed the theory of the Christian spirituality of the virtue of poverty.

Monks who vowed to lead their lives according to these rules devoted their lives to God, and from God they expected to obtain everything they needed. The abbot pledged to serve as an earthly administrator of these earthly necessities. Such reliance on the superior in the financial aspects was supposed to remove the monk's worry about earning his living and to deny him the right to possess anything of his own. ${ }^{195}$

In chapter LXXXII of the Rule of the Master its author differentiated between the people who just existed in the world (such as a pilgrim, a soldier, an emperor, a peasant, or a mercenary) "all have as their incentive, and work in order to have as long as they are alive, the means to be clothed, shod and fed," ${ }^{196}$ and those who were called by God to serve him, whom Lord showed "that they should not be much concerned about the present world - for all this passes away." 197 The desires of those who were called by God should be directed towards God, eternity, just and eternal matters, and not towards earthly concerns or material necessities of this life. ${ }^{198}$ Thus, the monk's worldly matters were taken care of by the abbot. ${ }^{199}$ The abbot's care for the material needs of his monks ${ }^{200}$ justified the lack of possessions:

\footnotetext{
195 A. de Vogüé, Povertà, op. cit., p. 267.

196 The Rule of the Master LXXXII, 3, 247.

197 The Rule of the Master LXXXII, 4-5, 247.

198 The Rule of the Master LXXXII, 6-12, 247.

199 The Rule of the Master LXXXII, 16-17, 247.

200 The Rule of the Master LXXXII, 23-25, 248.
} 
it is forbidden to have anything of one's own in the monastery because "no one in the service of God entangles himself in worldly affairs, that he may please him whose approval he has secured." Thus, when he has subjected himself and everything that belonged to him to the dominion of another, nothing is left to activate his self-will, which is the enemy of God's will. ${ }^{201}$

In order to substantiate his thesis, the author of the Rule of the Master referred to, as the quoted passage proves, 2 Tim 2:4 and Acts 5:1-11 which described a deceit committed by Ananias and Sapphira against the Jerusalem community for which they were punished by being struck dead instantly. ${ }^{202}$ In order to successfully impose the discipline of renunciation, the author of the Rule of the Master allowed the abbot to punish the monks ("a major and long-lasting excommunication") who kept part of their property to themselves in order to teach the other monks that they should not imitate the punished. ${ }^{203} \mathrm{He}$ also recommended frequent controls to verify that monks did not possess anything of their own. What is more, if the superior noticed that a given monk is "well satisfied with himself or takes a great pleasure is some article of clothing, let it be taken from him and given to another, and that of the other to him, whatever it may be, so that self-will does not assert itself in him." ${ }^{204}$ Such drastic controls and humiliations were supposed to develop in the subordinates the spirit of renunciation of earthly goods and of longing for eternal goods. The monk observing the Rule of the Master was to trust completely God's Providence and the foundation of the virtue of individual poverty. He was also expected to distance himself from the material results of communal work. ${ }^{205}$

\footnotetext{
201 The Rule of the Master LXXXII, 18-19, 247-248.

202 The Rule of the Master LXXXII, 20-22, 248.

203 The Rule of the Master LXXXII, 26-27, 248.

204 The Rule of the Master LXXXII, 29-30, 248.

205 A. de Vogüé, Povertà, op. cit., p. 267; cf. Reguła Mistrza LXXXVI, 4-13, 251.
} 
176 The studies regarding monasticism and voluntary poverty...

\section{Conclusion}

It seems that the spreading coenobitic ideal in the Western Church triggered a systematic radicalisation in the ideologically ascetic attitude towards the issue of possession at the beginning of the sixth century. The realistic approach towards possession that had been present in the fifth century disappeared for some time from the Western Church. Feudal lords were allowed to own some private property whereas in the case of monks possession of goods was considered vile. The renunciation of property - that had to take place before the vows of stability and conversion of manners were professed - seems to be an essential element of monastic spirituality according to The Rule of the Master. Monks were supposed to own nothing of their own and the abbot was the sole master of the monastery goods for life. He was to divide goods among his subordinates according to their needs. Monks were to put their trust in God and strive after heaven rather than take pleasure in or rely on worldly possessions. However, aiming for the abbot's full jurisdiction over the entire monastery property indicates the impact of the Roman civil law regarding the management of corporate property on the monastic law concerning the monastery goods. 


\section{VIII}

\section{The Regulations concerning monastic poverty in the rule of Eugippius (530/535)*}

The rule of abbot Eugippius was one of the most interesting monastic rules from the beginning of the $6^{\text {th }}$ century. This article depicts how the idea of monastic poverty, the norms of which were taken by Eugippius from a variety of monastic sources, evolved into gradual subordination to the idea of obedience, principal for the monks of the 6th century.

\section{Eugippius of Noricum and his Rule}

Eugippius (Latin forms of the name: Eugippius; Eugyppius) ${ }^{1}$ was born about the year 467 in the Roman province of Noricum (currently the area of the Styria and Carinthia regions in Austria), and presumably died about the year 533/35 in Castellum Lucullaum

* This article was originally published under the title: Przepisy dotyczace ubóstwa monastycznego $w$ Regule Eugipiusza (ok. 530-535), [in:] Lex Tua Veritas. Księga pamiątkowa dedykowana Jego Magnificencji Księdzu Profesorowi Janowi Maciejowi Dyduchowi z okazji 70. rocznicy urodzin, red. P. Majer, A. Wójcik, Kraków 2010, p. 137145 (Studia, t. 17, WN UPJPII w Krakowie).

1 Cassiodorus, Institutiones Divinarum et Saecularium Litterarum 23, 1: ed. R. A. B. Mynors, Clarendon Press, Oxford 1961², 62; Fulgentius of Ruspe, Epistula 5, 1: CChSL 91, ed. J. Fraipont, Brepols, Turnhout 1968, 235; Ferrandus of Cartagena, Epistula 4: PLS, 4, 1, 38. 
The studies regarding monasticism and voluntary poverty...

(currently Pizzofalcone, Naples) in the monastery built near the grave of St. Severinus of Noricum. ${ }^{2}$ His life was connected with the monastic community founded by St. Severinus. It is unknown when Eugippius entered it. We know, however, that he was present during St. Severinus death on 8 January 482, and then in 488 he participated in the exhumation of his body and moving it to Italia and in his funeral in Lucullanum (about 492-496). Eugippius was ordained around the year 509, and when abbot Marcianus died around the year 510/11, he was chosen the next abbot of St. Severinus monastery in Castellum Lucullanum. ${ }^{3}$

The Rule of abbot Eugippius was a collection of monastic precepts aimed at spiritual formation of the monks in St. Severinus monastery ${ }^{4}$ and for centuries it was considered lost. Only comparative studies of the critical edition The Rule of the Master, especially its second Parisian manuscript 12205 (pages $9^{\mathrm{r}}-7^{\mathrm{v}}$ ), done by Adelbert de Vogue OSB, showed that this manuscript contains the rule of abbot Eugippius from Lucullanum. ${ }^{5}$ The Rule of the Master was created between the year 525 and 530, ${ }^{6}$ The Rule of Eugippius

2 Jerome of Stridon, De viris illustribus 13(26): MPL 83, 1097; Ferrandus of Cartagena, Epistula 4: PLS, 4, 1, 38.

3 Eugippius, Commemoratorium 44, 1: SCh 374, ed. Ph. Régerat, Paris 1991, Polish transl.: The Life of St. Severinus. The Diary 43, 9: ŹM 13: Eugippius, The Life of St. Severinus. The Rule, tłum. i red. K. Obrycki, Kraków 1996, 132; ibid., 44, 5-7: SCh 374, 288.290; ŹM 13, 134-135; ibid., 46, 1-6: SCh 374, 292-296; ŹM 13, 136-139; Eugippius, Epistola ad Paschasium (Polish transl.: The Letter to Paschasius) 1.6: SCh 374, 150; ŹM 13, 57.59; cf. R. Noll, Eugippius. Das Leben des heiligen Severin, Berlin 1963, p. 34. For more about Eugippius of Noricum see: K. Obrycki, Życie i działalność literacka Eugipiusza, PSP 32: Eugippius, Dzieła, Warszawa 1985, p. 11-27; K. Obrycki, Wstęp, ŹM 13,12-16.

4 A. de Vogüé, Quelques observations nouvelles sur la Règle d'Eugippe, "Benedictina" 22 (1975), p. 31-41.

5 A. de Vogüé, Nouveaux apercus sur un regle monastique du VIe siecle, "Revue d'ascétique et de mystique" 41 (1965), p. 19-54; A. de Vogüé, Scholies sur la Règle du Maître, "Revue d'Ascétique et de Mystique" 44 (1968), p. 121-160, 261-292; A. de Vogüé, La Règle d'Eugippe retrouvée?, "Revue d'Ascétique et de Mystique" 47 (1971), p. 233-265; A. de Vogüé, Quelques observations nouvelles sur la Règle d’Eugippe, "Bénédictina” 22 (1975), p. 31-41; A. de Vogüé, Praefatio, CSEL 87: Eugipius, Regvla, a cura di F. Villegas, A. de Vogüé, Vien 1976, p. III-XXVII.

6 A. de Vogüé, La Règle du Maître 1, 1: SCh 105, vol. 1, Paris 1964, p. 223. 
was most likely written between 530 and 535 , while the creation of The Rule of St. Benedict is thought to have taken place between 530 and $560 . .^{7}$ In the view of the above dating of the rules, A. de Vogue OSB points out that there is no proof that St. Benedict of Nursia knew The Rule of Eugippius. It can only be stated that Eugippius and then Benedict were both enlightened by the same spirit and motivated by the same thought. ${ }^{8}$

Eugippius referred indirectly to the model of monastic life left in a form of spoken instruction by St. Severinus who invoked the tradition of Egyptian coenobites. ${ }^{9}$ It is hard to ascertain to what extent Eugippius considered the ascetic instruction of St. Severinus in his rule due to the fact that the content and organisation of The Rule of Euggipius is said to be a cento of earlier texts authored by a number of Fathers and other monastic writers..$^{10}$ In the process of creation of this document Eugippius used the monastic rules of Pachomius, Basil, Cassian, the Lerins Rule of the Four Fathers, ascetic writings of St. Jerome of Stridon, and most of all The Rule of the Master and The Rule of St. Augustine. ${ }^{11}$ Especially the last blend is very intriguing as Eugippius was trying to combine different styles of monastic spirituality: - augustinian, which emphasises life in community and fraternal love - with The Rule of the Master, in which case the anonymous author pointed at hierarchical rules in a monastic community and absolute obedience to the abbot. ${ }^{12}$

A. de Vogüé, Les dates de s. Benoît et de sa Règle d'après quelques trvaux récents, Etudes sur la Règle de s. Benoît, Nouveau Recueil (Spiritualité monastique 34), Bégrollesen-Mauges 1996, p. 387-415; A. de Vogüé, Génèse de la Règle bénédictine, "Collectanea Cisterciensia" 59 (1997), p. 229-241.

8 A. de Vogüé, Le Maître, Eugippe et S. Benoît, Regulae Benedicti Studia, Supplementa 17, Hildesheim 1984, p. 259-333.

9 H. Dickerhof, "De institutio sancti Severini.” Zur Genese der Klostergemeinschaft des Heiligen Severinus, "Zeitschrift für Bayerische Landesgeschichte” 46 (1983), p. 3-36.

10 A. de Vogüé, La Règle d'Eugippe et la fin du Prologue de S. Benoît, "Collectanea Cisterciensia" 41 (1979), p. 265-273.

11 A. de Vogüé, La Règle de saint Benoit, vol. 1, Paris 1972, SCh 181, 33-39; K. Obrycki, Wstęp, ŹM 13, 45-47.

12 K. Obrycki, Wstęp, ŹM 13, 41. 
The studies regarding monasticism and voluntary poverty...

\section{The theme of monastic poverty in The Rule of Eugippius}

The Rule of Eugippius, as a collection of monastic precepts based on previous rules, was a document of monastic formation written for the monastery of St. Severinus in Castellum Lucullanum. With regard to regulations concerning the matter of monastic poverty Eugippius drew on the rules of St. Augustine's Praeceptum while creating his own monastic cento. The norms taken from the anonymous Rule of the Master and The Rule of the Basil the Great were complementing the augustinian principles.

\subsection{The Rule of Eugippius' principles concerning monastic poverty taken from St. Augustine's of Hippo Praeceptum}

When Eugippius was setting the main principles of the life of monks, already at the beginning of his Rule (chapter I) he used the norms from St. Augustine's Praeceptum ${ }^{13}$ and subdued brothers' life to observing the great commandment of love of God and neighbour (cf. Mt 22:37-40), "since these are the greatest commandments we were given."14 Then he pointed at the need for prayer and the ways of saying $i^{15}$ as well as the duty of working and reading in the monastery. ${ }^{16}$ Monastic poverty is only listed as the fourth duty to

\footnotetext{
13 At the moment the greatest researchers working on the augustinian Rule (among others Verheijen, T. J. van Bavel and G. Lawless) accept the thesis that St. Augustine of Hippo was the author of Praeceptum, which he wrote in the garden near the church in Hippo Regius as a rule for the brothers from the monastery about the year 397 . Historically the earliest testimony attributing the authorship of Praeceptum to St. Augustine was Eugippius. For more about the authorship of Praeceptum see: P. Nehring, Wstęp. Św. Augustyn, Pisma monastyczne, ŹM 27, Kraków 2002, 67-76.

14 Eugippius, The Rule I, 1-2: CSEL 87, 3; ŹM 13, 140.

15 Eugippius, The Rule I, 3-9: CSEL 87, 3; ŹM 13, 140.

16 Eugippius, The Rule I, 10-11: CSEL 87, 3; ŹM 13, 141.
} 
be done by the brothers. ${ }^{17}$ This initial and conditional motivation to keep the norms of monastic poverty was repeated by Eugippius after augustinian Praeceptum I, $2^{18}$ in the subsequent fragment of The Rule I, $31 .{ }^{19}$ The monks' unanimity resulting from accepted by all brothers common ideals of apostolic life constituted the grounds for retaining monastic poverty.

The idea of collective poverty was described the most thoroughly by Eugippius in a large quotation from augustinian Praeceptum I, 3-8. In reference to the ideal of the unanimity of faith (Acts 4:32-36) no monk should refer to anything as his own. Eugippius - after Augustine of Hippo - reasonably noticed the differences in the social background of the monks and for that reason he was encouraging everybody to constantly lift their minds to God. Eugippius also repeated after St. Augustine the rule which said that each monk should be provided with everything that is necessary to fulfill his individual needs. The fair partition of goods according to needs was subdued to the decision of the superior.

As it is evident from the quoted texts, the appeal to the ideal of the Jerusalem community from Acts $4: 32-35,{ }^{20}$ already classic in the $6^{\text {th }}$ century, was the main grounds for renouncing the right to own any private property by the monks. In the first chapter of

17 Eugippius, The Rule I, 12-13: CSEL 87, 4; Polish transl.: „Let nobody consider anything his own property, neither clothes, nor anything else, as we want to live the life of apostles": ŹM 13, 141.

18 Augustine of Hippo, Praeceptum I, 2: NBA VII/2, Latin text. L. Verheijen, red. N. Cipriani, Roma 2001, 30; own transl.: "The main reason why you have gathered is this so that you lived in the house unanimously and had one heart and one spirit directed towards God" (own transl.): ŹM 27, Polish transl. M. Starowieyski, Kraków 2002, 15; cf. Ps 67:7; Acts 4:32.

19 Eugippius, The Rule I, 31: CSEL 87, 5; own transl.: "The main reason why you have gathered together is 't be unanimous as the inhabitants of his house' and 'to have one heart and one spirit» directed towards God": ŹM 13, 142.

20 Acts 4: 32-35: All the believers were one in heart and mind. No one claimed that any of their possessions was their own, but they shared everything they had. With great power the apostles continued to testify to the resurrection of the Lord Jesus. And God's grace was so powerfully at work in them all that there were no needy persons among them. For from time to time those who owned land or houses sold them, brought the money from the sales and put it at the apostles' feet, and it was distributed to anyone who had need: $\mathrm{BT}^{4}$. 
The studies regarding monasticism and voluntary poverty...

\begin{tabular}{|c|c|}
\hline Eugippius of Noricum, The Rule I: $32-37$ & Augustine of Hippo, Praeceptum I: $3-8$ \\
\hline $\begin{array}{l}\text { And do not claim that any of your pos- } \\
\text { sessions is your own but let everything } \\
\text { be collective, your superior allot food and } \\
\text { clothing, however, not equally to everyone } \\
\text { but according to individual needs. You can } \\
\text { read in the Acts of the Apostles that: "eve- } \\
\text { rything was collective" and "each was al- } \\
\text { lotted according to his needs." Those who } \\
\text { owned some goods in the world should } \\
\text { share them eagerly having entered the mo- } \\
\text { nastery. Those who did not own anything } \\
\text { should not seek in the monastery what } \\
\text { they previously could not have. Their ne- } \\
\text { eds, however, should be fulfilled even if } \\
\text { being outside the monastery, due to the- } \\
\text { ir poverty, they did not have the most es- } \\
\text { sential things. Do not let them be happy } \\
\text { due to the fact that they found food and } \\
\text { clothing which outside the monastery they } \\
\text { lacked. Let them not be conceited becau- } \\
\text { se they joined those whom they would not } \\
\text { dare approach outside the monastery, but } \\
\text { let them raise their hearts to heaven and } \\
\text { not seek wordly goods. Let the monasteries } \\
\text { be places in which neither the rich nor the } \\
\text { poor benefit as otherwise both the rich will } \\
\text { be humiliated and the poor will take pri- } \\
\text { de. Let those, on the other hand, who tho- } \\
\text { ught that they did mean something in the } \\
\text { world, not despise their brothers as they } \\
\text { came from poverty to this holy communi- } \\
\text { ty. Let them not pride themselves on their } \\
\text { wealthy parents' name, but rather on their } \\
\text { poor brothers' company. Let them not be } \\
\text { conceited if they happened to bring some } \\
\text { of their property to the collective life, ne- } \\
\text { ither let them pride themselves on their } \\
\text { wealth that they gave to the monastery in- } \\
\text { stead of using it in the world. Giving it out } \\
\text { to the poor and becoming poor oneself wo- } \\
\text { uld be in vain if the poor soul, spurning the } \\
\text { wealth, becomes more haughty then when } \\
\text { in possession of it. All of you, live in uni- } \\
\text { ty and concord and worship God in one } \\
\text { another as you are his temple. }\end{array}$ & $\begin{array}{l}\text { And do not claim that any of your posses- } \\
\text { sions is your own but let everything be col- } \\
\text { lective for you and let your superior allot } \\
\text { food and clothing to each of you, however, } \\
\text { not equally, as not each of you is in equal- } \\
\text { ly good health, but rather as much as each } \\
\text { of you needs. You can read in the Acts of } \\
\text { the Apostles that: "everything was collec- } \\
\text { tive and each was allotted according to his } \\
\text { needs." Those who owned some goods in } \\
\text { the world should share them eagerly having } \\
\text { entered the monastery. Those who did not } \\
\text { own anything should not seek in the mo- } \\
\text { nastery what they previously could not } \\
\text { have. Their needs, however, should be ful- } \\
\text { filled due to their weakness, even if outsi- } \\
\text { de the monastery they lived in such pover- } \\
\text { ty that they did not find what they needed. } \\
\text { However, they should not consider them- } \\
\text { selves happy due to the fact that they found } \\
\text { food and clothing, which they could not find } \\
\text { outside the monastery. Let them not take } \\
\text { pride in the fact that they joined those } \\
\text { whom they would not dare approach out- } \\
\text { side the monastery but let them raise the- } \\
\text { ir hearts and not seek vain wordly goods. } \\
\text { Do not let the monastery become benefi- } \\
\text { cial only to the rich and not the poor, that } \\
\text { is: if only the rich became humble in it while } \\
\text { the poor took pride in it. On the other hand, } \\
\text { those who thought that they meant some- } \\
\text { thing in the world, should not despise the- } \\
\text { ir brothers who came from poverty to this } \\
\text { holy community. Let them not be conceited } \\
\text { even if they brought some of their wealth to } \\
\text { the life in the community, nor let them take } \\
\text { pride in their wealth and the fact that they } \\
\text { gave it to the monastery instead of enjoying } \\
\text { it in the world. Every other vile pushes to- } \\
\text { wards bad acts while pride awaits good de- } \\
\text { eds to destroy them. What use in giving } \\
\text { one's wealth out to the poor and becoming } \\
\text { poor oneself when the poor soul turns out } \\
\text { to be more proud when spurning the wealth } \\
\text { than when possessing it. You should all live } \\
\text { unanimously and in concord, worship God } \\
\text { in one another as you became his temple. }\end{array}$ \\
\hline
\end{tabular}

1 Eugippius, The Rule I, 32-46: CSEL 87, 5-6; own translation; Polish transl.: ŹM 13, 142-144.

2 Augustine of Hippo, Praeceptum I, 3-8: NBA VII/2, 30.32; own translation; Polish transl.: ŹM 27, 155-157. 
his rule Eugippius quoted literally the passus from augustinian Praeceptum I, 3-8 ${ }^{21}$ in which monastic poverty was motivated by Lukas ideal of Jerusalem community. ${ }^{22}$ In reference to those two sources the abbot from Lucullanum demanded from his monks to renounce individual property on the basis of the rule of leaving everything behind and to renounce collectively according to the rule under which each monk is provided with all he needs. Eugippius also repeated after Augustine that the monks must not accept any gifts and if they did and did not admit it, they should be penalized severely. ${ }^{23}$

Coenobites from Lucullanum had no right to individual property but were allowed to have collective property and to administer the possessions owned by the monastic community. The possessions of the monastery were managed by the abbot. When it came to practical tasks such as buying, commerce or else, "two brothers" were sent, who were supposed to carry out the abbot's orders, always remembering that they are God's servants: well-disciplined, meticulous, thorough and behaving according to the superior's orders:

If someone has to be sent due to some needs in the monastery, let two brothers go. Let nobody eat or drink without any special directive; it is not a part of the monastery's discipline. If brothers have to be sent to sell what was produced in the monastery, let them heed not to act against the order as they know they will enrage God in his servants. If they buy things for the monastery, let them do it thoroughly and meticulously as God's servants. ${ }^{24}$

${ }^{21}$ Augustine of Hippo, Praeceptum I, 3-8: NBA VII/2, 30.32; ŹM 27, 155-157; cf. Dz 4, 32.35 .

22 For more information regarding the understanding of monastic poverty according to St. Augustine of Hippo see the article: D. Sanchis, Pauvreté monastique et charitéfraternelle chez S. Augustin entre 393 e 403, "Studia Monastica" 4 (1962), p. 7-33.

${ }^{23}$ Augustine of Hippo, Praeceptum IV, 11: NBA VII/2, 38; ŹM 27, 162-163; Eugippius, The Rule I, 97-98: CSEL 87, 11; ŹM 13, 149.

24 Eugippius, The Rule I, 19-22: CSEL 87, 4; own transl., ŹM 13, 141. 
The studies regarding monasticism and voluntary poverty...

In the above directive in his rule Eugippius developed Augustine's short piece of advice: "when you leave, go together; when you reach your destination, stay together." ${ }^{25}$ However, Eugippius' piece of advice was evidently adapted to the monks of Lucullanum style of life. Besides the traditional control of "one monk by the other," also making sure that they follow the rule of obedience during fulfilling tasks such as buying or selling to meet the monastery's economic needs was emphasised. The idea of being obedient to the abbot in using the common property is repeated in The Rule of Euggipius I, 32-47 and is a calque of recommendations in augustinian Praeceptum I, 3-8. The collective property of the monastery managed by the superior, according to the recommendations of St. Paul in Romans 15: 6 and 1 Corinthians 3: 16 and 2 Corinthians 6: 16 , was meant to be the proof of unanimity, concord and worship of God in oneself and the other brothers, in both Augustine's and Eugippius' works. ${ }^{26}$

Euggipius also quoted St. Augustine's monastic rules concerning fasting and mortifying one's body according to the precept "as much as health allows." ${ }^{27}$ The abbot from Lucullanum emphasised, similarly to Augustine, that everybody in the monastery is supposed to work regardless of their previous social status: "let this reprehensible evil never happen (Latin detestanda perversitas) that the rich become - as far as they can - hard working, and the poor become effeminate." ${ }^{28}$ Towards the end of listing recommendations

25 Augustine of Hippo, Praeceptum IV, 2: NBA VII/2, 36; ŹM 27, 159.

26 Augustine of Hippo, Praeceptum I, 8: NBA VII/2, 32; own transl.: "Live unanimously and in concord, worship God in one another as you have become his temple": ŹM 27, 157; Eugippius, The Rule I, 47: CSEL 87, 6; Polish transl.: "Live in unity and concord and worship God in one another as you are his temple": ŹM 13, 144.

27 Augustine of Hippo, Praeceptum III, 1-5: NBA VII/2, 32.34; ŹM 27, 157-159; Eugippius, The Rule I, 53-68: CSEL 87, 7-8; ŹM 13, 144-146.

28 Eugippius, The Rule I, 63: CSEL 87, 8; ŹM 13, 145; Augustine, Praeceptum III, 4: NBA VII/2, 34; own transl.: "Let this unbearable evil not happen that in the monastery the previous rich work hard in themselves and the previous poor become delicate": ŹM 27, 158-159. 
concerning asceticism, work and food, Augustine paraphrased and Eugippius repeated the famous saying of the stoic philosopher Seneca the Younger: "it is not the man who has too little, but the man who craves more, that is poor" 29 - "it is better to need less than to have more." 30 The paraphrase of 1 Tim 2:9-10 and subsequently of St. Augustine's "let your clothing not be sumptuous, and do not attempt to make your attire admirable but rather your morals." ${ }^{11}$

\subsection{The Rule of Eugippius' principles concerning monastic poverty taken from The Rule of the Master and The Rule of St. Basil}

Undoubtedly, Eugippius used the most profusely when creating his own Rule. However, with regard to the theme of poverty, those borrowings are only visible in chapter II: Characteristics the cellarer of the monastery should have..$^{32}$ A brother who controlled his temptation of gluttony and greed was given the responsibility for supplying the monastery with foodstuffs and other necessary items. ${ }^{33}$ A cellarer was expected to show care for monastery's property, for dishes and tools, refrain from carelessness in his service

29 Seneca Lucius Annaeus, Epistulae morales ad Lucilium 2, 6: "Non qui parum habet, sed qui plus cupit, pauper est": http://www.intratext.com/IXT/LAT0230/_P2.HTM; Polish transl.: Seneka, Listy moralne do Lucyliusza, tłum. W. Kornatowski, red. K. Leśniak, Warszawa 1961, p. 6.

30 Augustine, Praeceptum III, 5: NBA VII/2, 34; ŹM 27, 159; Eugippius, The Rule I, 68: "melius est enim minus egere, quam plus habere": CSEL 87, 8; Polish transl.: ŹM 13, 146.

31 Eugippius, The Rule I, 69: CSEL 87, 8; ŹM 13, 146; Augustine, Praeceptum IV, 1: NBA VII/2, 36; ŹM 27, 159; cf. 1 Tm 2:9-10.

32 Eugippius, The Rule II, 1-25: CSEL 87, 16-18; ŹM 13, 154-156; Regula Magistri XVI, 1-66: SCh 106, text, ed. A. de Vogüé, Paris 1964, p. 72-84; The Rule of the Master, Cistercian Publications, trans. L. Eberle, Michigan, p. 162-165.

33 Eugippius, The Rule II, 1-2: CSEL 87, 16; Polish translation: "One needs to be choosen who can control any temptatiosn for gluttony; who would fear the judgement that was exercised on Judas, who had been a thief from the beginning": ŹM 13, 154; cf. The Rule of the Master XVI, 62-65: SCh 106, 82.84; ŹM 40, 181. 
The studies regarding monasticism and voluntary poverty...

and at the same time be a godly person - putting his trust in God. ${ }^{34}$ Goodness, justice and reasonable use of the monastery's property should be the precepts (listed in The Rule of the Master and mentioned by Eugippius in a form of antonyms) the cellarer should be guided by when dividing the material goods between other brothers. ${ }^{35}$ When it came to dividing goods, allotting money, drawing some financial sums or giving the poor a handout, the cellarer of the monastery depended on the decision of the abbot. ${ }^{36}$ The rule regarding alms is significant:

The cellarer is to give alms by order of the abbot when he is present. When he is not present, however, he may give alms to a poor man asking for them, because of the Lord's precept which says: "Give to everyone who asks you" and likewise: "Give, lest the one you refuse be Christ himself." 37

Hence, the distribution of the monastery's material goods was completely subdued to the abbot's rule and will, "on his orders and in his presence." A subordinate was not allowed to give a handout out of his own will in the abbot's presence as that decision depended on the superior of the monastery's power. A cellarer, guided by "his own" good will and mercy, was allowed to give small alms to the begging poor - only during the abbot's absence. Evangelical recommendations from Lukas 6:30 and Matthew 25:35-36 were becoming the norm of mercy in such situations.

\footnotetext{
34 Eugippius, The Rule II, 5-14: CSEL 87, 17; ŹM 13, 155-156; cf. The Rule of the Master XVI, 11-26: SCh 106, 74.76; ŹM 40, 178-179.

35 Eugippius, The Rule II, 15-19: CSEL 87, 17-18; ŹM 13, 156; cf. The Rule of the Master XVI, 27-31: SCh 106, 76.78; ŹM 40, 179.

36 Eugippius, The Rule II, 20-21: CSEL 87, 18; ŹM 13, 156; cf. The Rule of the Master XVI, 32-33: SCh 106, 78; ŹM 40, 179.

37 Eugippius, The Rule II, 22-25: CSEL 87, 18; ŹM 13, 156; cf. The Rule of the Master. Cistercian Publications, trans. L. Eberle, Michigan, p. 162-165.
} 
The last of the clear percepts in The Rule of Eugippius, directly relating to the matter of owning anything by the monks, was the ban, repeated after The Rule of St. Basil, ${ }^{38}$ on possessing any individual property by the brothers. ${ }^{39}$ The ideal vision of a Jerusalem community described in Acts 4:32 "It was stated that 'No one claimed that any of their possessions was their own, but they shared everything they had.' Hence, if anybody claimed that any of their possessions was their own, then they were certainly excluding themselves from the community of the ones chosen by God and were moving away from the Lord's love." 40

\section{Conclusion}

Practicing monastic poverty according to the principles included in The Rule of Eugippius was meant to develop on the basis of Lukas' ideal of the primal Jerusalem community described in Acts 4:3236 . The detailed norms concerning monks' poverty were created by abbot Eugippius basing on the precepts in St. Augustine's Praeceptum and indirectly on The Rule of the Master and The Rule of St. Basil. In the context of the whole Rule of Eugippius, obedience was the most important monastic virtue and it was based on absolute trust put in God and his will - as expressed in the abbot's words. Practicing the virtue of poverty by the monks from the abbey in Castellum Lucullanum was meant to be a solid proof of that trust put in God only and not in people. For that reason the monks who lived according to the Rule of Eugippius were obliged to renounce private property - in order to take their hearts away from

38 Basil the Great, Regulae fusius 32, 1: MPG 31, 993.995; Polish transl.: Greater Rules: ŹM 6. St. Basil the Great, The Monastic Writings, t. 2, tłum. J. Naumowicz, Kraków 1995, p. $132-134$.

39 Eugippius, The Rule XIII, 1-4: CSEL 87, 26; ŹM 13, 164.

40 Eugippius, The Rule XIII, 2-3: CSEL 87, 18; ŹM 13, 164. 
188 The studies regarding monasticism and voluntary poverty...

material benefits and devout themselves to heavenly goods only; they were to undertake the tasks ordered by the abbot eagerly in order to fulfill - following the example of Christ - the will of God the Father expressed in the abbot's order; and through their care for collective property or objects allotted to private use they were fulfilling God's will more faithfully.

The Rule of Eugippius did not play any major part in developing monastic asceticism of the $6^{\text {th }}$ century. Nevertheless, the recommendations of the abbot Eugippius of Lucullanum concerning poverty clearly point at certain tendency present in the $6^{\text {th }}$ century rules: poverty was heavily subdued to the virtue of obedience and was to mean not only renouncing the right to possess any material goods but also individual opinions and predilections. Through renouncing material goods and own will - under the rule of the abbot - the monks were to achieve the Evangelical ideal of unanimity of thought. 


\section{The issue of possessing material goods in the teachings of St. Peter Chrysologus's, the bishop of Ravenna*}

Since the $3^{\text {rd }}$ century the issue of possessing material goods by Christians had been discussed in terms of predicatory opposition of "wealth - poverty," which in subsequent centuries became a classical Christian topic of this subject matter. ${ }^{1}$ Poverty itself became a spiritual virtue and a social category in the Christian rhetoric of the $4^{\text {th }}$ and $5^{\text {th }}$ century, and "a poor person" was equated with Christ. ${ }^{2}$ Bishops took up the role of protectors of the poor, and their almsgiving became a sign of religious authority as well as

* This article was originally published under the title: Zagadnienie posiadania dóbr materialnych $w$ kazaniach św. Piotra Chryzologa, biskupa Rawenny, [in:] Zbytek i ubóstwo w starożytności i średniowieczu, red. L. Kostuch, K. Ryszewska, Kieleckie Towarzystwo Naukowe, Kielce 2010, p. 279-286.

1 Cf.: V. Neri, I marginali nell'Occidente tardoantico. Poveri, "Infames" e criminali nella nascente società cristiana, Edipuglia, Bari 1998 (Collana Munera: Studi storici sulla Tarda Antichità 12); Poveri ammalati e ammalati poveri. Dinamiche socio-economiche, trasformazioni culturali e misure assistenziali nell'Occidente romano in età tardoanti$c a$, a cura di R. Marino, C. Molè, A. Pinzone, Edizioni del Prisma, Catania 2006 (Collana: Testi e studi di storia antica 5); Poverty in the Roman World, eds. M. Atkins, R. Osborne, Cambridge University Press, Cambridge 2006.

2 P. Brown, Poverty and leadership in the Later Roman Empire, The Menahem Stern Jerusalem Lectures, University Press of New England, Hanover (NH) 2002, p. 1-44; cf. Sympozja kazimierskie poświęcone kulturze świata późnego antyku i wczesnego chrześcijaństwa, t. 3: Biskup i jego rola $w$ ksztaltowaniu miasta późno antycznego, red. B. Iwaszkiewicz-Wronikowska, D. Próchniak, Towarzystwo Naukowe KUL, Lublin 2002 (The works of the Historical Philological Department, 92). 
The studies regarding monasticism and voluntary poverty...

the unification of the community, which differentiated Christians from their non-Christian/pagan neighbours. ${ }^{3}$ The teachings of St. Peter Chrysologus of Ravenna (circa 380 - circa 450) regarding wealth and poverty fit in with this historical context. In this article I will first discuss the issue of general right of property in St. Peter Chrysologus perspective, and subsequently I will proceed to discussing the issues of universal destination of material goods, alms, criticism of greed and criticism of usury in the teachings of the eighteenth bishop of Ravenna.

\section{The acknowledgement of the right of property of material goods}

St. Peter Chrysologus, between 424/431 and 450 the bishop of Ravenna, ${ }^{4}$ which at that time was the capital of the West Roman Empire, acknowledged the right to own material goods. The theological justification of the right of property was derived by Chrysologus from the biblical concept of matter, ${ }^{5}$ which he understands as the one created by God and for that reason entirely dependent on the Creator. ${ }^{6}$ Only God can dispose all creation according to his will, as he is the only one who gives and takes away existence to all beings

3 R. Finn, Almsgiving in the Later Roman Empire. Christian Promotion and Practice 331-450, Oxford University Press, Oxford-New York 2006, p. 34-89.

4 For more about Peter Chrysologus see: D. Kasprzak, Duszpasterze Vwieku. Studium porównawcze myśli pasterskiej św. Piotra Chryzologa i Salwiana z Marsylii, Kraków 2008, p. 52-68.

5 R. De Vaux, Ekonomia, ibid., Instytucje Starego Testamentu, t. 1, tłum. T. Brzegowy, Poznań 2004, p. 178-209; ibid., Bibliografia, vol. 1, XI. Ekonomia, p. 561-564.

6 Peter Chrysologus, Sermo 46, 6: "His is the sea and he himself created it. Therefore you will believe that the sea was searched for and found and not created by God, although, his is the sea and he himself created it. Where are those who think that God molded the world from matter, and most of all from water? Our God is in heaven and on earth not as a discoverer but as a creator of matter he made everything from nothing": Opere di san Pietro Crisologo [further cited as OSPC] 1, a cura di A. Olivar et al., Milano-Roma 19961997, p. 322 (own English transl.of the writings of Peter Chrysologus); cf. Ps 95 (94):5. 
created by him. ${ }^{7}$ In the perspective of human heading towards heaven, the value of material goods is relative, as no mundane material wealth can be taken after death, ${ }^{8}$ and the only permanent thing that is worth investing in by a believer is God and heavenly goods. ${ }^{9}$ The bishop of Ravenna pointed out that man cannot overrate material goods, they should be used by him and not dominate him. ${ }^{10}$ Chrysologus, as most of the Fathers of the fourth and fifth century, ${ }^{11}$ described precisely the limits of the authority of possession inferred from the Revelation. The possibility of possessing and managing goods in the mundanity comes from God. As the authority given by God, and not constituted by men, it is also defined in reference to its origin (God) and its duration (until man's death). God gives his creation all authority, and for that reason there is no authority

7 Peter Chrysologus, Sermo 46, 5: "Since in his hands are the borders of earth. Since everything that is in God's hands cannot be received without God; is we wish to broaden the borders, to widen limits, to take back what we had lost. Let's then pray to God with strong faith, as having offended him, we lost everything that, thanks to his mercy, comes back to us multiplied. He is the one, who gives to whom he wants and takes away from whom he wants. The one who cannot give back, is not considered almighty": OSPC 1, 322; cf. Ps 95 (94):4.

8 Peter Chrysologus, Sermo 22, 3: "Human, if you are to stay here, secure what belongs to you; but if you are to go further, why don't you leave here what is yours? The one who guards what he is supposed to leave, is a guardian of somebody else's goods, and not his own wellness": OSPC 1, 180.

9 Peter Chrysologus, Sermo 22, 1-2: "Do not be afraid, lottle flock, as your Father's will is to give you the kingdom. He adds what the ones called to ruling should do: Sell your possessions and give alms! Obtain money-belts that will not be destroyed - inexhaustible treasure in heaven": OSPC 1, 178; cf. Lk 12:32-33; Peter Chrysologus, Sermo 22, 3: "The inexhaustible treasure in heaven. That is to say: bring it where I am, give it to me and I will guard it. Human, give it to the Father, entrust it to God, as the Father does not refuse his heir what is intended for him, what was promised to him, and God will not take it away from human": OSPC 1, 178; cf. Lk 12:33.

10 Peter Chrysologus, Sermo 22: 2: "One cannot rule all things if one is absorbed in one's own possessions": OSPC 1, 178. Chrysologus's clear reference to Gen 1:28.

11 C. I. Gonzales, La destination universelle des biens. Aspects patristiques, [in:] Une terre pour tous les hommes. Colloque international Justice et Paix, Paris 1992, p. 16-31; T. Makowski, Polskojęzyczna bibliografia patrystycznego dziedzictwa społecznej myśli Kościola, [in:] Patrystyczne dziedzictwo spolecznej nauki Kościoła. VIII Bydgoskie Dni Spoleczne. (14-18 III 1994), red. T. Makowski, Gniezno 1996, p. 95-101. 
The studies regarding monasticism and voluntary poverty...

that does not come from God. ${ }^{12}$ Therefore each host ${ }^{13}$ should bear in mind that he is only a temporary administrator and not an absolute ruler of the mundane possessions entrusted to him..$^{14}$

\section{The universal purpose of goods}

Peter Chrysologus, in his teachings, developed a similar concept regarding the universal purpose of goods. Managing the material goods is not a unique right of some people only, as all people on earth are merely administrators of their own possessions and on earth it is temporary. ${ }^{15}$ Chrysologus pointed out that the usage of goods is a form of service (Latin ministerium), and it has got a fleeting - mundane (Latin temporariae) dimension. Therefore nobody should ascertain that one owns something as his eternal possession. Mortal man only acquires temporary and not eternal right to own possessions. Therefore he should share his possessions with others on earth and the criterion should be love. ${ }^{16}$

12 Peter Chrysologus, Sermo 26: 5: “The Apostle says: The is no authority that does not come from God. If all authority comes from God, the king received his authority from God as well. The general and his soldiers, as well as the administrators of provinces and cities, all of them will have to give a report: did they transgress their competence? (si in nullo creditae potestatis excessere mensuram)": OSPC 1, 202; cf. Rom 13:1.

13 Peter Chrysologus, Sermo 26: 6: "I want also you to believe that, being the host in your house, you are the administrator, not the owner": OSPC 1, 204.

14 Peter Chrysologus, Sermo 125: 4: "Wealthy was the man who had an administrator. Who was the administrator if not the person to whom all possessions of the world were entrusted to care for it?": OSPC 3, 10. Chrysologus again refers to the Biblical vision of entrusting the world to man by God, cf. Gen 1:28.

15 Peter Chrysologus, Sermo 125: 11: "It would be good for us if we applied the described events to us, we, who have to feel administrators here on earth, and not call ourselves the owners; we have to be convinced that we are on duty for a certain amount of time and that we have not gained the eternal right of property": OSPC 3, 14; cf. Lk 16:1-9.

16 Peter Chrysologus, Sermo 162, 3: "Teacher, tell my brother to share his inheritance with me. The earthly inheritance causes disputes among the heirs; before dividing the inheritance between the individual persons, he divides the heirs and puts them in opposite positions. For that reason it is not heritage but rather a fight, that is a stepmother for 
Pagans, as the ones who reject God and the revealed truths, were considered by Chrysologus the unfair administrators of the earthly goods, as having renounced God, they run into idolatry and worshipped money. ${ }^{17}$

\section{Alms}

In Peter Chrysologus's understanding, and similarly to his contemporary Christian authors, teachings regarding Christian meaning of alms constituted a party of a broader theme concerning Christian mercy. ${ }^{18}$ Giving material aid to a man in need from religious motives is a response to God's call for being merciful. ${ }^{19}$ Each

children, and not wealth. Only the one who leaves true love behind makes his children richer": OSPC 3, 264; por. Lk 12:13.

17 Peter Chrysologus, Sermo 126: 5: "The pagan nation is referred to as the unfair administrator due to their wealth accumulated in a vile manner. Gain friends, he says, by means of unworthy mammon. While the nation that abandoned the Creator, entrusted the whole self to the wealth": OSPC 3, 20; cf. Lk 15:11-32; Lk 16:9; Peter Chrysologus, Sermo 126: 6: "The Administrator of this wealth, that is the pagan nation, is guilty of wasting the material goods in that way, is called, by means of the Gospel, by the Lord himself, to give report on their managing of the gifts of the nature": OSPC 3: 20.22; Peter Chrysologus, Sermo 126: 5: "Whoever is free from the slavery of wealth and is not oppressed by the burden of money shall stop in the celestial observatory and from there shall see how money, with the fury of a tyrant, rules the world and people. It gives orders to nations, it rules kingdoms, causes wars and fights, sells blood, causes death, betrays motherlands, destroys cities, subordinates peoples, assieges fortresses, maltreats citizens, sits in tribunals, destroys the law, sets traps for honesty, violates the truth, usurps fame, loses justice, eliminates innocence, puts mercy in grave, divides families, does not allow friendship. What more shall be said? That is mammon: the lady of injustice as she rules oven the bodies and minds in a dishonest way": OSPC 3: 20; Peter Chrysologus, Sermo 126: 6: "The order of faith provides salutary advice for the administrator to return to his proper Lord, to dispose this cruel owner, that is mammon, in a generous manner, to subordinate it to his own service and to make sure that what so far had been an occasion to perdition would now become the way to": OSPC 3: 22.

18 R. Finn, Almsgiving in the later Roman Empire. Christian promotion and practice, op. cit., p. 34-220.

19 Peter Chrysologus, Sermo 7: 6: OSPC 1, 88; cf. Mt 6:19-20; Peter Chrysologus, Sermo 8: 5: OSPC 1, 96; cf. Oz 6:6, Ps 36 (35):6. 
The studies regarding monasticism and voluntary poverty...

believer, within his capability, is called to give alms to men in need. ${ }^{20}$ From the religious point of view, giving alms leads to the benefactor's sins being forgiven. ${ }^{21}$ The acts of mercy are the signs of sinner's conversion and his cooperation with God..$^{22}$ On the basis of the discussion in Lk 12:33, Chrysologus encourages to the acts of so called holy trade: alms - given to God through the hands of the poor in mundaneness will be accumulated and rewarded by God. ${ }^{23}$ The benefactors are always supposed to remember that giving alms should be secret, honest and most of all should be pleasant to God. ${ }^{24}$

20 Peter Chrysologus, Sermo 26: 7: OSPC 1, 204.

21 Peter Chrysologus, Sermo 14: 5: "The one who knows the truth about treading through life among the evil of this world shall carry with him the aid of alms, shall call the poor for his protection. [...] On the day of persecution the Lord shall liberate him. On the day of unhappiness the Lord shall be his liberator, the Lord who freed the poor from the evil. In difficulties God shall hear his scream, the God who heard the poor. The one who caused the poor to enjoy peaceful days shall not suffer times of adversity. On the other hand, the one who will have no support of the poor on the day of judgment shall see the day of unhappiness. In vain so sinners accuse the one who is excused by the poor. However, the one accused by the starvation of the poor shall not be excused": OSPC 1,132; por. Ps 41 (40):2.

22 Peter Chrysologus, Sermo 28: 5: OSPC 1, 218; cf. Mt 9:12; Mt 9:13.

23 Peter Chrysologus, Sermo 25: 2: "Sell what you have and give alms. If you think that you will live, that you will rule; if you believe that you will be rich in the heavenly kingdom, where you will have your place, where you will emigrate, where you will rule, then your goods come there before you; use evil wealth by means of compassion, turn humans goods into divine goods. To avoid shortage of means to transport what you will leave behind, the poor were called; the poor are the ones who carry your burden and carry it willingly, as they ave no burden of their own but are free. Sell, he says, what you have and give alms. Prepare money-belts that do not wear off, everlasting treasure in heaven, where a thief has no access and a woodworm does not destroy. Prepare money belts that do not wear off. You can see that this Father want his children to be rich, and not deprived of all. Prepare money belts that do not wear off. In a new way, what is more, in a divine way, the one who can hear - by selling, he buys, places his fortune in the vault and in that way he makes it bigger, by losing, he gains. Prepare money belts, money belts that do not wear off, for the money to last, for the money belts have no limits, for the accumulated wealth to be durable": OSPC 1, 196.198; cf. Łk 12:33.

24 Peter Chrysologus, Sermo 9: 3-4: OSPC 1, 102; cf. Mt 6:2; Peter Chrysologus, Sermo 54: 8-9: OSPC 1: 370; cf. Lk 19:8-9. 


\section{Criticism of greed}

Peter Chrysologus, similarly to other ascetic Christian writers of the $4^{\text {th }}$ and $5^{\text {th }}$ century, ${ }^{25}$ treated greed as the source of evil in man, distortion of morals and the break of fundamental human relations. ${ }^{26}$ It is a sin and it originates from earthly wealth. Therefore, in order to prevent it, one should renounce earthly possessions and give them out to the needy. ${ }^{27}$ The spiritual effect of greed, which only brings mundane wealth, is the loss of inner peace and certainty of faith. ${ }^{28}$ Greed significantly influences the value of people's endeavours - through absolutizing the material goods, man defines oneself only in reference to mundaneness and forgets about his call for eternal life and heaven. ${ }^{29}$ For that reason God exhorts man to reject greed and to transform earthly possessions, through alms, into the gift of heaven. ${ }^{30}$ In his earthly life, material possessions are only give to man as a loan, for the time of his life. Therefore, giving

25 R. Newhauser, The early history of greed. The sin of avarice in Early Medieval thought and literature, Cambridge University Press, New York 2000, p. 70-95.

26 Peter Chrysologus, Sermo 162: 8: "Beware of all greed. It is equivalent to the statement: renounce greed and it shall not impede you from gaining your heritage. Greed, my brothers, negates parents, divides brothers, separates companions, dissolves friendship, puts down feelings. The one who will have it in him, will not be on anybody's side, will not be himself. Greed, my brothers, as the apostle says, is the root of all evil, and whet it roots in your heart, it distorts morals and just like a poisonous tree, it destroys the monuments of the ancestors": OSPC 3: 238, cf. Lk 12:15; 1 Tm 6:10.

27 Peter Chrysologus, Sermo 7: 6: OSPC 1:90; cf. Mt 6:19-20.

28 Peter Chrysologus, Sermo 23: 3: "The one who guards gold, who conserves silver, will never be certain, has lost his peace, as the one who is not certain loses peace; such a man becomes rich, but rich in guilt, not the essence": OSPC 1: 178.

29 Peter Chrysologus, Sermo 22: 3: "Human, if you are to stay here, guard what belongs to you; but if you are to go up, why are you leaving here what is yours? The one who guards what one needs to leave behind, is the guardian of the somebody else's goods, not his own. If in this life, which we live now and in which we are strangers, we agree to certain discomfort of being poor for some time only, what then it means to be sad and disrespected in the heavenly kingdom?": OSPC 1: 180.

30 Peter Chrysologus, Sermo 25: 2: "Sell what you have and give alms. [...] trough compassion use the miserable wealth, what belongs to people, turn into divine goods": OSPC 1: 196; cf. Lk 12:33. 
The studies regarding monasticism and voluntary poverty...

alms, through the acts of mercy towards his neighbours, man pays his debt back to God. ${ }^{31}$

\section{Criticism of usury}

Mentions regarding usury which can be found in teachings of Peter Chrysologus are similar to the opinions of other Fathers of the Church. ${ }^{32}$ The bishop of Ravenna criticises usury as an example of the egoistic interest loan which lacks the foundation of mercy towards other people and the only aim of which is immediate profit and mundane increment. According to Chrysologus, God wants people to show mercy to one another, and he wants that not for himself but his aim is to give his mercy to people. ${ }^{33}$ Showing active mercy is in opposition to the attitude of a usurer. Therefore, mercy constituted for the bishop of Ravenna the evangelical interpretation of virtues securing the eternal life. ${ }^{34}$

31 Peter Chrysologus, Sermo 25: 3: "Gain the treasure through donations for the poor as the Heavenly Father takes as a deposit all that a poor person receives. [...] Human, entrust to God what God gave to you. He, as the one who gives, if it is his will to be your debtor, will want to give you more": OSPC 1: 198; cf. Lk 12:33.

32 R. P Maloney, The teachings of the fathers on usury. A historical study on the development of Christian thinking, "Vigiliae Christianae" 27 (1973), p. 241-265.

33 Peter Chrysologus, Sermo 8: 5: "God announces: I want compassion. The one who denies God what he wants, wants God to negate what he wants. I desire compassion. Human, God asks for you, not for himself. Compassion I desire. He asks for human compassion to spread divine compassion. There is compassion in heaven, which can be gained by the acts of mercy on earth. Lord, he says, your compassion is in heaven": OSPC 1:96; cf. Oz 6:6; Ps 36 (35):6.

34 Peter Chrysologus, Sermo 47: 2: “The term 'merchant' is not offensive to anyone who listens to this words: it refers to a merchandiser who gives mercy, and not the one who gives loans always thinking about usury [...] This merchandiser sells the pearls of the heart and body not as a part of human but divine trade. He does it not for immediate benefit but to gain the eternal reward; not for earthly but for heavenly fame; to gain the kingdom of heaven as a compensation for his virtues, to buy this one and only pearl of eternal life": OSPC 1: 326; cf. Mt 13:45-48. 


\section{Conclusions}

St. Peter Chrysologus's views regarding the issue of owning and using material goods follows the classical for the practical-positive attitude towards the predicatory (rhetoric) question of wealth-poverty omnipresent in Western Christianity of the $4^{\text {th }}$ and $5^{\text {th }}$ century. The bishop of the caesarean Ravenna of the fifth century emphasised the good origin of matter and material goods. Good because coming from God. Therefore he postulated for the proper acquisition and usage of the possessions. Contrary to the attitude towards material goods taken by the representatives of the ascetic-negative approach, who constantly highlighted the danger that wealth constituted to the spiritual life (and therefore postulating for renouncing any possession), Chrysologus pointed out that the authority connected with possessing comes from God, not from people. For that reason it is defined due to its divine origin and its duration - until a man's death. In his teachings, the bishop of Ravenna emphasised the universal usage of goods, the criterion of which should be love and idolatry and worshipping money. He encouraged to give alms to the needy in a reasonable manner and directed people's attention towards so called holy trade (eternal salvation in return for earthly alms). He criticised greed and usury (as idolatry and lack of mercy). Peter Chrysologus's teachings regarding the Christian ownership was typical of the fifth century. However, one should learn how to renounce possession for merciful reasons, so that, through alms and charity, one could gain eternal salvation. 


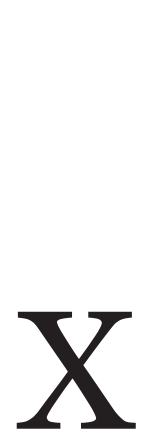

\section{Monastic life as proceeding the "narrow path" of obedience according to the Rule of Eugippius*}

Eugippius of Noricum (born in 476, died c 533/535), from 510/511 the abbot of the monastic community of St. Severinus of Noricum in Castellum Lucullanum (nowadays Pizzofalcone, Naples), between 530 and 533/535 wrote a monastic rule ${ }^{1}$ intended for spiritual formation of the monks in his monastery. ${ }^{2}$ This document is a cento of various monastic texts (the rules of Pachomius the Great, Basil of Caesarea, The Institutiones et Conlationes of John Cassian, the Lerins Rule of the Four Fathers, the ascetic writings of Jerome of Stridon, The Rule of Augustine of Hippo and The Rule of the Master). ${ }^{3}$ It is not easy to ascertain, to what extend

1 * This article was originally published under the title: Życie monastyczne jako podążanie wąska droga postuszeństwa wedtug Reguty Eugipiusza, [in:] Fructus Spiritus est Caritas. Księga Jubileuszowa ofiarowana Księdzu Profesorowi Franciszkowi Drączkowskiemu z okazji siedemdziesiątej rocznicy urodzin, czterdziestopięciolecia święceń kapłańskich i trzydziestopięciolecia pracy naukowej, red. M. Wysocki, Wydawnictwo KUL, Lublin 2011, p. 181-195.

The critical edition: Eugippius, Regula: CSEL 87, a cura di F. Villegas, A. de Vogüé, Vien 1976; Polish transl.: Eugipiusz, Reguła: ŹM 13, tłum. i red. K. Obrycki, Kraków 1996, p. 140-228.

2 A. de Vogüé, Praefatio: CSEL 87, Vien 1976, III-XXVII; A. de Vogüé, Le Maître, Eugippe et S. Benô̂t, "Regulae Benedicti Studia" - Supplementa 17, Hildesheim 1984, p. 259-333; K. Obrycki, Życie i działalność literacka Eugipiusza, PSP 32: Eugipiusz, Dzieła, Warszawa 1985, p. 11-27; K. Obrycki, Wstęp, ŹM 13, Kraków 1996, p. 12-16.

3 A. de Vogüé, La Règle d'Eugippe et la fin du Prologue de S. Benoît, "Collectanea Cisterciensia” 41 (1979), p. 265-273. 
200 The studies regarding monasticism and voluntary poverty...

Eugippius referred to the established teaching of St. Severinus of Noricum and the valued by him tradition of the Egyptian coenobites, as in the Eugippius' rule there are neither direct quotes from St. Severinus' teachings nor any references to the Apophthegmata Patrum. ${ }^{4}$ Possibly, in the formation of his monks, abbot Eugippius was invoking the model of monastic life of St. Severinus of Noricum, which he himself described in The Life of St. Severinus. ${ }^{5}$ However, it is more a speculation than a fact noted in The Rule of Eugippius or The Life of St. Severinus.

While composing his rule of various fragments of ascetic writings of earlier authors, Eugippius did many changes in the original texts in order to adjust the created by him monastic law to the needs of monks in Castellum Lucullanum in the best possible way. The beginning of The Rule of Eugippius (abbreviation: R.E.) is an evident borrowing from The Rule of St. Augustine of Hippo (abbreviation: R.A.). However, the largest number of quotations come from The Rule of the Master. ${ }^{6}$ What is intriguing in The Rule of Eugippius is the connection of directions in spirituality which in certain aspects are different from one another: the Augustinian norms, which emphasise the role of life in community and brotherly love, and The Rule of the Master (abbreviation: R.M.), which highlights strict obedience to the superiors. The norms of monastic life included in The Rule of Eugippius were meant to be read out in the monastic community on weekly basis for the record, in order to remember them and to adapt monks' life to them. ${ }^{7}$ The rule of monastic life which was discussed most often was obedience. This

4 H. Dickerhof, "De institutio sancti Severini." Zur Genese der Klostergemeinschaft des Heiligen Severinus, "Zeitschrift für Bayerische Landesgeschichte” 46 (1983), p. 3-36.

5 The critical edition: Eugippe, Vie de saint Séverin, ed. P. Régerat, Paris 1991; Polish translation: Eugipiusz, Żywot św. Seweryna (contains: List Eugipiusza do Paschazjusza, List Paschazjusza do kapłana Eugipiusza oraz Pamiętnik): ŹM 13, tłum. K. Obrycki, Kraków 1996, p. 57-139.

6 A. de Vogüé, Praefatio, CSEL 87, III-XXVII.

7 Eugippius, The Rule 1,152-154: CSEL 87, 16; ŹM 13, 154; cf. Jas 1:23-25; Mt 6:12-13. 
article's aim is to analyze the most characteristic features of the spirituality of obedience in Eugippius' understanding.

\section{Augustinian interpretation of monastic obedience}

The Eugippius' interpretation of monastic obedience was based on the spiritual interpretation of the following texts: Ex 20:12; Heb 13:7; Eph 6:1-2 “one should obey one's superior like his own father and pay him due respect not to offend God in him." $\mathrm{A}$ superior should constitute an image of God the Father for the monks and for that reason the subordinate monks were obliged to show him due respect, "in order not to offend God." The authority of the superior originated from his ordained ministry, ${ }^{9}$ and his competences included due care for respecting the norms of the community life by the monks, potential infliction of penalties,${ }^{10}$ keeping discipline and allocating duties to monks. ${ }^{11}$ If managing the community exceeded the "powers and aptitude" of the current superior, he should refer to the priest who was more appreciated amongst monks ("maior auctoritas"). ${ }^{12}$

According to the spiritual interpretation of Lk 22:25-26 and Gal 5:13, the superior, when exercising his authority over the others, should observe the rule of service and love, and not repress

8 Eugippius, The Rule 1,140: CSEL 87, 15; ŹM 13, 152; cf. Augustine of Hippo, Praeceptum 7,1: ŹM 27, tłum. P. Nehring, Kraków 2007, p. 166.

9 Eugippius, The Rule 1,141: “multo magis praesbytero, qui omnium uestrum curam gerit”: CSEL 87, 15; Polish transl.: “o wiele bardziej należy słuchać kapłana, który troszczy się o was wszystkich" ("the priest should be obeyed much more as he takes care of everybody”): ŹM 13, 152; cf. R.A. - Praeceptum 7,1: ŹM 27, 166.

10 Eugippius, The Rule 1,142: CSEL 87, 15; ŹM 13, 152-153.

11 Eugippius, The Rule 1,147: CSEL 87, 15; ŹM 13, 153.

12 Eugippius, The Rule 1,143: CSEL 87, 15; ŹM 13, 153; cf. R.A. - Praeceptum 7,2: ŹM 27, 167. 
202 The studies regarding monasticism and voluntary poverty...

his subordinates using the power he was given by election. ${ }^{13}$ The superior of the monastery, in relation to other brothers, was supposed to perform good deeds, be open and kind, patient ${ }^{14}$ and humble, and all that should originate from his fear of God, in the name of whom he exercised his authority over his subordinates. ${ }^{15}$ Therefore, on the basis of the text of Heb 13:17, the principal rule of the superior's behaviour was the calling: "let him seek your love more than your fear; always remember that he will give a report on you to God." 16

According to St. Augustine, quoted by abbot Eugippius, the monks who understood their life vocation in terms of God's grace, having become subordinates, they were obliged to observe the norms of life in obedience, with love, "as the devotees of the spiritual beauty."17 Therefore they should show good conduct in relation to their brothers, ${ }^{18}$ and through their behaviour they should teach others and themselves about the life of Jesus and bring him closer to everybody. That aspect was descriptively contained in the following poetic metaphor: "they breathed the sweet scent of Christ the Lord." 19 The life of obedience was not meant to be their servitude and they should not perceive themselves as slaves subjugated to monastic law or the abbot's authority. The decision to continue the life of obedience to their superior should be regarded as their free life choice dictated by God's grace. ${ }^{20}$

\footnotetext{
13 Eugippius, The Rule 1,144: CSEL 87, 15; ŹM 13, 153.

14 Eugippius, The Rule 1,146: CSEL 87, 15; ŹM 13, 153; cf. 1 Thes 5: 14; Heb 13:17.

15 Eugippius, The Rule 1,145: CSEL 87, 15; ŹM 13, 153.

16 Eugippius, The Rule 1,148: "tamen plus a uobis amari adpetat quam timeri, semper cogitans deo se pro uobis redditurum esse rationem": CSEL 87, 15; Polish transl.: ŹM 13, 153.

${ }_{17}$ Eugippius, The Rule 1,150: "spiritalis pulchritudinis amatores": CSEL 87, 16; ŹM 13, 153; cf. Syr 44,6; R.A. - Praeceptum 8,1: ŹM 27, 168.

18 Eugippius, The Rule 1,150: CSEL 87, 16; ŹM 13, 154; cf. 1 Pt 3:16.

19 Eugippius, The Rule 1,150: "bono Christi odore": CSEL 87, 16; Polish transl.: ŹM 13, 154; cf. 2 Cor 2:15; R.A. - Praeceptum 8,1: ŹM 27, 168.

20 Eugippius, The Rule 1,151: CSEL 87, 16; ŹM 13, 154; cf. Rom 6:14-22; R.A. - Praeceptum 8,1: ŹM 27, 168.
} 


\section{Obedience according to The Rule of the Master}

The XVIII chapter of The Rule of Euggipius constitutes a repetition of the VII chapter of The Rule of the Master, which discusses the obedience of disciples and two fundamental types of monastic obedience: proper - without hesitation, and improper - indolent. The first type of obedience, unfortunately less rife, as it is "the form suitable for the few perfect ones," ${ }^{21}$ was also called humbleness. We talk about it when the subordinate shows his subjection to the abbot without "hesitation" ("oboedientia sine mora") ${ }^{22}$ and he fulfills the superior's orders quickly. ${ }^{23}$ The monks showing this kind of obedience ${ }^{24}$ immediately fulfill their superior's orders because they treat his words as instructions of God. ${ }^{25}$ This type of obedience originates from the fear of $\operatorname{God}^{26}$ and is additionally motivated by the willingness to avoid the punishment of hell or to gain the eternal life. ${ }^{27}$ Therefore, the monks characterized by obedience "without hesitation" get rid of their own will ${ }^{28}$ very quickly at the recommendation of their superior and abandon their current tasks, all to complete the current instruction of the abbot..$^{29}$

The other type of obedience - contrary to one discussed above was more common. It was rhetorically described as the type of obedience represented by people with "weak and indolent minds, overpowered by hopelessness," ${ }^{30}$ often encountered amongst the monks,

${ }_{21}$ Eugippius, The Rule 18,10: "sed haec paucorum perfectorum forma”: CSEL 87, 29; Polish transl.: ŹM 13, 167.

22 Eugippius, The Rule 18,1: CSEL 87, 29; ŹM 13, 166.

23 Eugippius, The Rule 18,4: CSEL 87, 29; ŹM 13, 166.

24 Eugippius, The Rule 18,2: CSEL 87, 29; ŹM 13, 166.

25 Eugippius, The Rule 18,5-6: CSEL 87, 29; ŹM 13, 166-167; cf. Ps 17:45; Lk 10:16.

26 Eugippius, The Rule 18,9: CSEL 87, 29; ŹM 13, 167.

27 Eugippius, The Rule 18,3: CSEL 87, 29; ŹM 13, 166.

28 Eugippius, The Rule 18,7: CSEL 87, 29; ŹM 13, 167.

29 Eugippius, The Rule 18,8: CSEL 87, 29; ŹM 13, 167.

30 Eugippius, The Rule 18,10: "infirmorum et pigrium animos in disperatione": CSEL 87, 29; ŹM 13, 167. 
204 The studies regarding monasticism and voluntary poverty...

as the abbot of Castellum Lucullanum said: "we see that there are many people amongst us, who are like pots, pitiable since the lazy nature has gathered much indolence in them." ${ }^{31}$ The requirements regarding the indolent and lazy ones ("infirmorum et pigrium") were "more benign," 32 the superior's orders were repeated twice without incriminating the subordinates, ${ }^{33}$ and the indolent monk was at fault only when he did not fulfill the order that had been repeated three times by the abbot. ${ }^{34}$

\section{2a. Undue obedience, i.e. non-coenobite (in other words: sarabaite obedience or following "the wide path")}

Abbot Eugippius, when discussing the question of the two types of monastic obedience, repeated, after The Rule of the Master 7, the characteristic distinction, which with time became the exegesis of the monastic excellence in the Western Church. In the asceticspiritual interpretation of Mt 7:13-14, the "without hesitation" way of obedience was described as narrow, the one that leads to life. The "indolent and lazy" type of obedience was called the wide path that leads to perdition:

Since such judgment needs to be used in referrence to two types, that is to "the wide path that leads to perdition," and to "the narrow path that leads to life." Obedience of different people goes along those two paths, i.e. obedience of the lay monks, sarabaites, wandering monks who live in twos or threes with no superior and who order to one another whatever suits them, follows the wide path; they defend what they want for themselves, and

\footnotetext{
31 Eugippius, The Rule 18,11: CSEL 87, 29; ŹM 13, 167.

32 Eugippius, The Rule 18,13: CSEL 87, 30; ŹM 13, 167.

33 Eugippius, The Rule 18,14-16: CSEL 87, 30; ŹM 13, 167.

34 Eugippius, The Rule 18,17: CSEL 87, 30; ŹM 13, 168.
} 
because none of them want to give in, their conduct is never free of indignation. ${ }^{35}$

A monk showing undue obedience, described above as indolent and lazy, was aforementioned as the one who follows the wide path, which leads to perdition, the lay monk, the wandering monk or the sarabaite monk. ${ }^{36}$

The latter name is quite noteworthy. As Adelbert De Vogüé OSB noticed, in the Coptic language, the name referred to the monks with anchorite tendencies, separated from the convent. ${ }^{37}$ In the West, St. Jerome ${ }^{38}$ was the first one to describe such separatist monks. He depicted them in his Letter to Eustochium written in $384 .{ }^{39}$ When talking about the monks living together by twos or

35 Eugippius, The Rule 18: 18-23: "Nam et illud de duabus uiis congrue hic et conuenienter taxandum est, id est latam, quam ducit ad interitum, et angustam, quae ducit ad vitam. In quibus duabus uiis diuersorum hominum oboedientiae gradiuntur, id est, per latam uiam saecularium et sarabaitarum et girouagorum monachorum, qui aut singuli aut bini aut terni sine maiore ipsi sibi aequaliter uiuentes, et pro alterno imperio quidquid cuique placuerit sibi uicibus inuicem imperantes, et quae uoluerint peculiariter in se defendentes, cum in proprio unusquisque consilio non uult se uinci, scandalum sibi tales numquam faciant esse absentem": CSEL 87, 30; own English transl.; Polish transl.: ŹM 13, 168.

36 Eugippius, The Rule 27: 6-10: "Tertium uero monachorum deterrimum genus est sarabaitarum, quem melius adhuc laicum iam dixissem, si me propositi sancti non inpediret tonsura. Qui nulla regula adprobati et experientia magistro sicut aurum fornacis, sed in plumbi natura molliti, adhuc factis seruantes saeculo fidem, mentiri deo per tonsuram noscuntur. Qui bini aut terni aut certe singuli sine pastore, non dominicis sed suis inclusi ouilibus, pro lege eis est desideriorum uoluntas, cum quidquid putauerint uel legerint, hoc dicunt sanctum, et quo noluerint hoc putant non licere. Et dum in proprio arbitrio quaerunt habere cellas, arcellas et rescellas, ignorant quia perdunt suas animellas": CSEL 87, 48; Polish transl: ŹM 13, 185; cf. R.M. 1.

37 A. de Vogüé, Sarabaiti, [in:] Dizionario degli Istituti di Perfezione, vol. 8, a cura di G. Rocca, Roma 1988, p. 985.

38 More about the perception of monasticism by Jerome of Stridon in: B. Degórski, L'insegnamento monastico geronimiano, "Vox Patrum" 17 (1997) 32-33, p. 199214; V. Desprez, Początki monastycyzmu. Dzieje monastycyzmu chrześcijańskiego do Soboru Efeskiego (431), t. 2, tłum. J. Dembska, Kraków 1999, p. 259-265; B. Degórski, L'insegnamento monastico geronimiano (continuazione), "Vox Patrum" 20 (2000) 3839, p. 487-503.

39 Jerome of Stridon, Letter 22,34: PL 22, 419; 1. Polish transl.: "Trzy są w Egipcie rodzaje mnichów: cenobici, których tamtejsi mieszkańcy nazywają w swym języku sauses, 
The studies regarding monasticism and voluntary poverty...

threes, he called them "remnuoth." ${ }^{40}$ The first Polish translator of St. Jerome's Letter XXII to Eustochium, Rev. Jan Czuj, suggested, after the Jacques Paul Migne's edition, that the name "remnuoth" used by Jerome could have originated from the Greek $\rho \varepsilon \mu \beta o ́$, , i.e. meanderer ${ }^{41}$ The second translator of the text, father Bazyli Degórski O.S.P.P.E, chose a different solution. He used a Latin alliteration of the possible Coptic term "remnuoth," however, leaving the name not translated.

It appears that father Adalbert de Vogüé OSB explains well the meaning of the above term. Accodring to him, the name remnuoth,

my zaś możemy nazywać wspólnie żyjącymi; anachoreci, którzy w pojedynkę mieszkają na pustyni, i stąd ich nazwa, ze odosobnili się od ludzi; trzeci rodzaj: remboci”: PAX 2, tłum. J. Czuj, Warszawa 1952, p. 151; 2. Polish transl.: "Trzy są rodzaje mnichów w Egipcie: cenobici, których w barbarzyńskim języku nazywają 'sauhes,' a my możemy nazywać ‘żyjący we wspólnocie;' anachoreci, którzy mieszkają pojedynczo na pustyniach i są tak nazwani, ponieważ odchodzą daleko od ludzi; trzecim rodzajem jest ten, który zwie się 'remnuoth": ŹM 33, tłum. B. Degórski, Kraków 2004, p. 172-173.

40 Jerome of Stridon, Letter 22,34: PL 22, k. 419; 1. Polish transl.: "trzeci rodzaj: remboci, najgorszy i zaniedbany; jest to, jeśli nie jedyny, to przeważający rodzaj mnichów w naszej prowincji. Ci mieszkają razem po dwóch lub trzech albo niewielu więcej, żyjąc według swego upodobania, a z tego co zapracują, składają część do wspólnej kasy, by mogli mieć wspólne pożywienie. Mieszkają zaś prawie wszyscy w miastach i twierdzach; nie życie, ale przebiegłość u nich zdaje się być święta, bo cokolwiek sprzedają, to uważają za rzecz wielkiej wartości. Często powstają między nimi waśnie, bo żyjąc swym chlebem nie znoszą uległości wobec innych. Mają zwyczaj współzawodniczyć w postach, a to, co powinno być tajemnicą, robią przedmiotem zwycięstwa. Wszystko w nich jest przesadne: szerokie rękawy, obuwie wykrzywione, suknie grubsze, częste westchnienia, odwiedzanie dziewic, uwłaczanie duchownym, a gdy przyjdzie dzień uroczysty, objadają się aż do wymiotów": PAX 2, 151-152; 2. Polish transl.: “trzecim rodzajem jest ten, który zwie się 'remnuoth' - najgorszy i pogardzany, a który w naszej prowincji jest albo jedynym, albo pierwszym. Oni to razem mieszkają po dwóch lub trzech, względnie nie wiele liczniej, żyjąc według własnej woli i programu. Z tego zaś, co wypracowują, dają [jedynie] część do wspólnoty, w celu zapewnienia wspólnego pożywienia. Mieszkają zaś bardzo często w miastach i osadach, a cokolwiek sprzedają, więcej kosztuje, jakby rzemiosło było święte, a nie życie. Częste są wśród nich kłótnie, gdyż mając własny wikt - nie znoszą, by komuś podlegać. Prawdę powiedziawszy, mają zwyczaj uprawiać zawody w poszczeniu, czyniąc [przedmiot] zwycięstwa z czegoś, co powinno pozostać w ukryciu. Wszystko u nich jest sztuczne: szerokie rękawy, człapiące obuwie, grubsza szata, częste wzdychania, odwiedzanie dziewic, obgadywanie duchownych. Gdy zaś nadejdzie bardziej świąteczny dzień - jedzą aż do wymiotów": ŹM 33, 172-173. According to father J. Czuj, PAX 2, note 5, 151, Jerome, when he says "in our province," does not mean Palestine, but rather Pannonia.

41 PAX 2, note 4, 151. 
referring to a group of Egyptian monks, originates from the Coptic

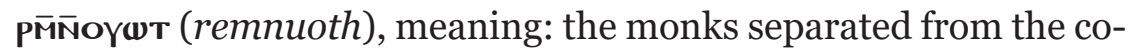

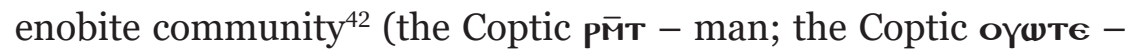
separation; the Coptic оүшт - alone).$^{43}$ The description provided by St. Jerome was taken over by John Cassian, ${ }^{44}$ who used a new term to name those monks - Sarabites ${ }^{45}$ (etymologically - either from the Coptic: сардвдыт; the Coptic cap - prefix used to create words naming performers of some actions, in this case "the separated," the Coptic двєт - the convent, that is separated from the convent; but also, and that seems more likely, from сдрдкшете, meaning a wanderer, a vagabond). ${ }^{46}$ After Cassian, the term Sarabaites was also used by the author of The Rule of the Master, ${ }^{47}$

42 A. de Vogüé, Sarabaiti, 895. This opinion is also shared by Antoine Guillaumont, Les "remnuoth" de saint Jérôme, [in:] Christianismes d'Egypte. Hommages à René-Georges Coquin, Louvain 1995, p. 87-92 (Cahiers de la Bibliothèque, copte 9).

43 W. Vycichl, Dictionnaire étymologique de la langue copte, Leuven 1983, p. 173-174.

44 A. de Vogüé, Monachisme et Église dans la pensée de Casien, [in:] Théologie de la vie monastique. Etudes sur la tradition patristique, ed. G. Lemaître, Paris 1961, p. 213-240 (Collection Théologie, 49).

45 John Cassian, Conferences 18,7,2: PL 49, 1103-1104; Polish transl.: "Ale ten przykład, przez stanowczość apostolską u Ananiasza i Safiry ukarany, powoli zanikł z oczu niektórych i z czasem wskutek długiego niedbalstwa zatarł się w pamięci. Wtedy zjawił się ów rodzaj sarabaitów, którzy dlatego, że się odłączali od zgromadzeń klasztornych i na własną rękę dogadzali swoim potrzebom, nazwani zostali z egipska sarabaitami, pochodzili zaś, jak wyżej powiedziałem, z liczby tych, którzy woleli raczej udawać doskonałość ewangeliczną, aniżeli rzetelnie do niej dążyć, powodowani zazdrością i sławą tych, którzy nad wszystkie bogactwa świata kładą doskonałe ubóstwo Chrystusowe (PL 49, 1104: "perfectam Christi praeferunt nuditatem')”: POK 7, tłum. L. Wrzoł, Poznań 1929, p. 245.

46 W. E. Crum, Coptic dictionary, Oxford 1939, p. 354; W. Vycichl, Dictionnaire étymologique de la langue copte, Leuven 1983, p. 196.

47 The Rule of the Master 1,6-10: SCh 105, ed. A. de Vogüé, Paris 1964, 330; English transl.: "The third kind of monks the sarabaites, is the worst. I would do better to call them still of the world, except that the tonsure of their religious intent prevents me from doing so. Untested, as gold in the furnace, by any rule or by experience as a master, soft as lead, they still keep faith with the word and manifestly lie to God by their tonsure. Two or three together, or even alone, without a shepherd, enclosed not in the Lord's but in their own sheepfold, they have as their law the willfulness of their own desires, whatever they think and decide, that they cal holly, and what they do not want, that they consider forbidden. And while they want to have cells, chests and various things according to their own judgment, they are unaware that they are losing their own petty souls," Cistercian Publications, trans. L. Eberle, 
208 The studies regarding monasticism and voluntary poverty...

then by Eugippius - in his Rule 18:20, and subsequently the name "Sarabaites" was repeated in The Rule of Benedicte, ${ }^{48}$ and in the form: "Sarabaites - remnuoth" also by Isidore of Seville. ${ }^{49}$

The monks of this type supposedly lived mostly in Egyptian cities. Then they started spreading, especially in the cities of Italia. Remnuoth/Sarabaites were accused by both St. Jerome and Cassian of being independent and concupiscent, of initiating quarrels and causing chaos. However, no responses of the said monks to such accusations can be found anywhere... What is more, no remnuoth/Sarabaites are mentioned by the Greek or oriental sources of that time. As Adalbert de Vogüe suggests, the discussed remnuoth/Sarabaites were most likely the category of monks depicted and judged negatively only by the Western writers, ${ }^{50}$ presumably created "for pedagogical reasons," to help keep discipline in the Western abbeys. The etymology itself could result from wrong interpretation of the Coptic сардкштє - wanderer, vagabond. ${ }^{51}$ The observations of Adalbert de Vogüé are confirmed by Malcolm Choat. In his article, Malcolm draws a conclusion that it is quite possible that in Egypt at the turn of the 3rd century, a third type of monks existed that fitted in the standards

Michigan 105, Polish transl.: ŹM 40, tłum. T. M. Dąbek OSB, Kraków 2006, p. 91-92; The Rule of the Master 7,24-25: SCh 105, 386; English transl.: "Thus, on the broad road go men of the world and the sarabite and gyrovague monks. These live alone or two or three together, without a superior, on an equal footing and moving about as they please," Cistercian Publications, trans. L. Eberle, Michigan 121, Polish transl.: ŹM 40, 119.

48 The Rule of St. Benedict 1,6-7: SCh 181, ed. A. de Vogüé, Paris 1972, p. 438; Polish transl.: "Sarabaici, to trzeci i wstrętny rodzaj mnichów. Nie są oni wypróbowani przez żadną regułę i pouczające doświadczenie, jak złoto w piecu, lecz miękcy jak ołów, jeszcze przez swoje postępowanie dochowują wiary służbie świata, kłamiąc Bogu przez tonsurę. Oni po dwóch lub trzech, albo nawet pojedynczo żyją bez pasterza, nie w pańskiej owczarni, lecz we własnej, mając za prawo zaspokojenie pragnień swej rozkoszy": ŹM 40, tłum. B. Turowicz OSB, Kraków 2006, p. 392-393.

49 Isidore of Seville, De ecclesiasticis officiis 2,16,9-10: "Aegiptiorum linguae sarabaitae, sive remobothitae nuncupantur": PL 83, 799B.

50 A. de Vogüé, Sarabaiti, 895.

51 Por. W. E. Crum, Coptic Dictionary, Oxford 1939, p. 354. 
of the Latin ascetic writers such as e.g. Jerome or John Cassian. Those writers depicted such monks in a negative way, even though they used the Coptic terms which in the case of Jerome as well as in Cassian were not so unequivocally negative in their meaning. However, Coptic monks depicted as the said third type were acknowledged in the Egyptian, Syrian or Judeo-Christian reality of the turn of the $3^{\text {rd }}$ century. ${ }^{52}$

The abovementioned names used to refer to separatist monks, separated from the coenobium, were evidently Latin pejorative terms, evaluating the monks negatively due to the fact that they were independent of the authority of the formal abbot, "by twos or threes without any superior." Moreover, those monks had their own concept of monasticism ("they live and order one another to do whatever they consider likeable; they defend what they desire for themselves; and because none of them ever yields, their conduct is never free of indignation"), which because of that was considered by R.M. and R.E. as demoralizing and showing the wrong intention, ${ }^{53}$ leading to disputes among the monks ${ }^{54}$ and conclusively to getting into the enemy's hands, herein compared to a wolf (cf. Mt 9:36; Ez 34:5; $1 \mathrm{Kgs} 22: 17) .{ }^{55}$ According to the authors of R.M. and R.E., even $\mathrm{God}^{56}$ did not take care of the monks who did not live according to an acknowledged canonic rule ("nulla regula adprobati") ${ }^{57}$ as

52 M. Choat, Philological and historical approaches to the search for the "third type" of Egyptian monk, [in:] Coptic studies on the threshold of a New Millennium. Proceedings of the seventh congress of Coptic studies, Leiden, August 27 - September 2, 2000 , eds. M. Immerzeel, J. Van Der Vliet, Leuven 2004, p. 857-865 (Orientalia Lovaniensia Analecta, vol. 2).

53 Eugippius, The Rule 18,24: CSEL 87, 30; ŹM 13, 168.

54 Eugippius, The Rule 18,24: CSEL 87, 30; ŹM 13, 168.

55 Eugippius, The Rule 18,25: CSEL 87, 30-31; own transl. from Polsih.: "and they wander like sheep with no shepherd, like sheep that disperses in various places and becomes a prey of a wolf": ŹM 13, 168.

56 Eugippius, The Rule 27,6: CSEL 87, 48; own transl. from Polish: "they do not accept any rule": ŹM 13, 185.

57 Eugippius, The Rule 18,26: "prouidente sibi non deo": CSEL 87, 31; Polish translation: "when God does not look after them": ŹM 13, 168. 
The studies regarding monasticism and voluntary poverty...

they took their decisions by themselves, ${ }^{58}$ e.g. "they decide themselves to change their cell," 59 or "they even usurp the title of abbot." 60

According to R.M. and R.E., another offence committed by the monks who, as it was said, followed the wide path of obedience, was that "they live together with the lay people taking up the common way of life, they tread - as it seems - a wide path ("via lata")."61 Accusing this group of monks of laicisation could prove the thesis of spreading so called Sarabaits in towns. The laicisation of those monks was not a form of evangelisation after the example of the Apostles - staying with people in order to live according to the Gospel in a radical way in their environment. It was a tendency of separating themselves from the coenobite community in order to live according to their own ascetic norms still retaining the outer signs of the priesthood ("on the outside only the tonsure distinguishes them"). ${ }^{62}$ The texts of R.M. and R.E. condemned the "wide path" monks for forming their own judgments, and especially for accepting the possibility of doing evil, ${ }^{63}$ for calling the things they did not want to do - prohibited, ${ }^{64}$ caring for body more than for soul, ${ }^{65}$ and for individual endeavours for their "food, clothing and footwear." ${ }^{66}$ R.M. and R.E. especially reproached them for renouncing the coenobite ideal of obedience, renouncing the council of elders, following their own spiritual discernment and being convicted that their way of life is the due monastic lifestyle ("they

\footnotetext{
58 Eugippius, The Rule 18,26: "arbitrio proprio": CSEL 87, 31; ŹM 13, 168.

59 Eugippius, The Rule 18,26: "nouas iterato cellas": CSEL 87, 31; ŹM 13, 168.

60 Eugippius, The Rule 18,26: "et de se solo sibi soli abbatis nomine inponentes": ŹM 13, 168.

${ }_{61}$ Eugippius, The Rule 18,27a: "in hoc enim uia lata talibus creditur ambulari, cum in nomine monachi communi more uiuentes cum laicis": CSEL 87, 31; Polish translation: ŹM 13, 168.

62 Eugippius, The Rule 18,27b: “solo tonsurae habitu”: CSEL 87, 31; ŹM 13, 168-169.

63 Eugippius, The Rule 18,28: CSEL 87, 31; ŹM 13, 169.

64 Eugippius, The Rule 18,29: CSEL 87, 31; ŹM 13, 169.

65 Eugippius, The Rule 18,30: CSEL 87, 31; ŹM 13, 169.

66 Eugippius, The Rule 18,31: "id est ut uictum et uestitum et caliciarium": CSEL 87, 31; ŹM 13, 169.
} 
think that [...] following only their own discernment they fulfilled all law and God's justice living in their cells"). ${ }^{67}$

The conflict between the coenobite ideal of life and the asceticism of so called Sarabaites, or in other words the proponents of the "wide path," was evident when they were visited by superiors of a certain monastery in order to convince those two or three monks living separately to join the community under the ruling of a given superior. The abbots of such canonical convents first admonished those monks - separatists and tried to convince them to live in closer community and, subsequently, tried to prove to them the futility of the recluse lifestyle. ${ }^{68}$ The advice of the coenobite superiors was usually rejected by the separatists. What they answered was that "they should be living simple life." ${ }^{\circ 9}$ Therefore they were accused by coenobite authors of R.M. and R.E. of demoralisation, ${ }^{70}$ heading for perdition, ${ }^{71}$ following the wide path to fulfill their own desires ${ }^{72}$ lusts ${ }^{73}$ dissipations and pleasures. ${ }^{74}$ According to the authors of R.M. and R.E., it was the way of fervency and spiritual deafness, ${ }^{75}$ leading eventually to the gallows ${ }^{76}$ and to death. ${ }^{77}$

It appears that the aforementioned formal opposition to eremitism is one of the most characteristic features of The Rule of Eugippius. It is possible that for that reason abbot Eugippius from the beginning of his monastic cento had been emphasising, after augustinian Praeceptum, the coenobite tendencies. As Adalbert

67 Eugippius, The Rule 18,32: "sub proprio arbitrio militantes, credunt se omnem legem et iustitiam dei perfecte in cellula operari”: CSEL 87, 31; ŹM 13, 169.

68 Eugippius, The Rule 18,33: CSEL 87, 31; ŹM 13, 169.

69 Eugippius, The Rule 18,34: CSEL 87, 31; ŹM 13, 169.

70 Eugippius, The Rule 18,35: CSEL 87, 31; ŹM 13, 169.

71 Eugippius, The Rule 18,36: CSEL 87, 31; ŹM 13, 169.

72 Eugippius, The Rule 18,37: CSEL 87, 32; ŹM 13, 169.

73 Eugippius, The Rule 18,38: CSEL 87, 32; ŹM 13, 169.

74 Eugippius, The Rule 18,39: CSEL 87, 32; ŹM 13, 169.

75 Eugippius, The Rule 18,42: CSEL 87, 32; ŹM 13, 170.

76 Eugippius, The Rule 18,40: CSEL 87, 32; ŹM 13, 169.

77 Eugippius, The Rule 18,41: CSEL 87, 32; ŹM 13, 169-170. 
The studies regarding monasticism and voluntary poverty...

de Vogüé notices, Eugippius chooses his quotations from the texts of Basil of Caesarea and Jerome of Stridon in order to condemn the eremitic way of life in the first case, and to challenge it in the second one. This literary means was an ideological indication of the fact that any attempts of moving away from the coenobium/ convent towards more individual or non-coenobite life were condemned. Eugippius also used a similar means when choosing texts from The Rule of the Master. He quotes in such a way to show the monks the necessity of not leaving the community and persevering in the monastery till death. ${ }^{78}$

\section{2b. The due, i.e. coenobite obedience}

Living the monastic life according to the rules of so called "narrow path" obedience, was different from the general understanding of obedience as "those who follow the 'narrow path' ('augustam uiam') are the ones who seek the eternal life."79 The link drawn between the future eternal life of a monk and his choice to follow the narrow path of coenobite obedience was an arbitrary and evidently rhetorical figure in R.M. clearly repeated by Eugippius. This kind of reasoning quite clearly indicated that all others, e.g. Sarabaites or Anachoretes, not being obedient to the abbot in a way that coenobites of a given rule were, would not bend their steps to heaven. The author of The Rule of the Master as well as Eugippius, who repeats similar expressions in his rule, clearly preferred coenobism ${ }^{80}$ as, in their understanding, it was the state indicating reformation,

\footnotetext{
78 A. de Vogüé, Il monachesimo prima di san Benedetto, Abbazia san Benedetto, Seregno (MI) 1998, p. 174.

79 Eugippius, The Rule 18,43: "e contrario, quibus uero ad uitam aeternam ambulandi amor incumbit, ideo angustam uiam arripiunt”: CSEL 87, 32; Polish transl.: ŹM 13, 170.

80 Eugippius, The Rule 27,19: CSEL 87, 49; Polish transl.: "Przeto uważając, że najlepszym jest pierwszy rodzaj mnichów, zwanych cenobitami, dla których wolą Bożą jest walka ze słabościami ciała i ducha oraz postęp na drodze doskonałości, przejdźmy do zasad regulujących ich życie”: ŹM 13, 186; cf. R.M. 1,75.
} 
renouncing evil and receiving the God's grace. ${ }^{81}$ A coenobite, as a humble disciple, subordinated himself to the superior because a coenobite always regarded himself as unwise..$^{82}$ The aim of such subordination of one's will to the orders of the superior was to spiritually form the monks-disciples under the supervision of superiors who, as the true teachers of the unwise, showed them the God's will. ${ }^{83}$ A coenobite was expected to resign his own will here on earth in order for the devil not to take control over him. A coenobite regarded his will to be weak, and the superior's will to be the right one and the one leading to God's glory. ${ }^{84}$ The monastery, in which monks renounced their will completely and subordinated it to their superiors, became the so called school of service to the Lord, and a monk staying in the monastery his whole life deserved in that way the eternal life. ${ }^{85}$

Therefore the coenobie monks, experiencing their obedience according to the rules of the "narrow path," were expected to renounce their own judgments, were not allowed to have desires (material $^{86}$ or spiritual), but were obliged to fulfill the orders of others and to act in compliance with their opinions. ${ }^{87}$ For coenobites, the norms of subordination to the orders of another person were as follow: subordination to the authority of the abbot, renouncing

81 Eugippius, The Rule 27,20-25: CSEL 87, 49; ŹM 13, 187; cf. R.M. 1,76-81.

82 Eugippius, The Rule 27,31: “quibus inspientia mater est”: CSEL 87, 50; ŹM 13,188.

83 Eugippius, The Rule 27,32-33: CSEL 87, 50; ŹM 13, 188.

84 Eugippius, The Rule 27,34-39: CSEL 87, 50; ŹM 13, 188.

85 Eugippius, The Rule 27,40-43: CSEL 87, 50-51; Polish transl.: "póki jeszcze jesteśmy w ciele i mamy możliwość - poprzez to, że żyjemy - gromadzić sobie te wszystkie dobra, trzeba się starać o to, co przyniesie nam pożytek w wieczności. Potrzeba nam zatem szkoły, w której moglibyśmy się nauczyć, jak służyć Panu, byśmy nigdy nie odstępując od jego przykazań i tej nauce będąc wierni w klasztorze aż do śmierci, zasłużyli stać się uczestnikami Męki Chrystusa przez cierpienie i współdziedzicami w Jego królestwie”: ŹM 13, 188-189.

86 To read more about the role of obedience according to Eugippius see: D. Kasprzak, Przepisy dotyczące ubóstwa monastycznego w Regule Eugipiusza (530/535), [in:] Lex Tua Veritas..., op. cit., p. 137-145.

87 Eugippius, The Rule 18,44-45: CSEL 87, 32; ŹM 13, 170. 
The studies regarding monasticism and voluntary poverty...

one's own name 88 and "renouncing one's own likes." 89 Both R.M. and R.E. referred to the words of Jesus from J 6: 38: "For I came down from heaven, not to do mine own will, but the will of him that sent me"90 as a model of denying oneself for Christ and noticing in the order of the superior following God. ${ }^{91}$ Obedience to the elder or the superiors was interpreted as a spiritual form of obedience to God. ${ }^{92}$

The role of a subordinate was compared to carrying a yoke. The yoke was the superior's order, ${ }^{93}$ patience in bearing the hardship of dependence - in comparison to martyrdom and the time of trial. ${ }^{94}$ The coenobite obedience itself was understood as mundane maceration of one's will which in effect was aimed at bringing the eternal life. ${ }^{95}$ In order for it to have a value of merit, it should be borne "without anxiety, devotedly, without indolence or showing reluctance, unrepiningly" 96 and also the subordinate should have positive attitude towards the superior. ${ }^{97}$ The subordinate was expected to fulfill all orders of the abbot with diligence and willingly ${ }^{98}$ and was not allowed to willfully abandon the task allotted to him. ${ }^{99}$ Only the superior allotted jobs in the monastery. ${ }^{100}$ When the time for saying the office came, a monk was obliged to leave his task and

\footnotetext{
88 Eugippius, The Rule 18,46: CSEL 87, 32; ŹM 13, 170.

89 Eugippius, The Rule 18,53: "ideo enim uia angusta a talibus creditur ambulari, quia propria in eis desideria minime adimplentur et non quo uolunt perficiunt”: CSEL 87, 33; ŹM 13, 171.

$90 \quad$ Eugippius, The Rule 18,47: CSEL 87, 32; ŹM 13, 170.

91 Eugippius, The Rule 18,48: CSEL 87, 32; ŹM 13, 170.

92 Eugippius, The Rule 18,64: CSEL 87, 34; ŹM 13, 172.

93 Eugippius, The Rule 18,54: CSEL 87, 33; ŹM 13, 171.

94 Eugippius, The Rule 18,55: CSEL 87, 33; ŹM 13, 171.

95 Eugippius, The Rule 18,61-62: CSEL 87, 33-34; ŹM 13, 171; cf. Ps 65:12.

96 Eugippius, The Rule 18,63: CSEL 87, 34; ŹM 13, 171-172.

97 Eugippius, The Rule 18,66-70: CSEL 87, 34; ŹM 13, 172.

98 Eugippius, The Rule 5,1-5: CSEL 87, 20-21; ŹM 13, 158-159.

99 Eugippius, The Rule 6: CSEL 87, 21; ŹM 13, 159.

100 Eugippius, The Rule 9-10: CSEL 87, 23; ŹM 13, 160-161; cf. The Rule of Basil $99,101,102,122$.
} 
to go to the oratory. ${ }^{101}$ If a monk was doing any work at a distance bigger that 50 feet from the gate, he was not obliged to participate in the common prayer, as he did not have enough time to come to the oratory with due dignity. ${ }^{102}$ Instead of that, he was to put the tools away in the place where he was working and to say appropriate prayers there. ${ }^{103}$ Similarly, provided it was necessary to do some urgent work in the monastery, the monks who were engaged in it, were obliged to chant individually in the place where they were working. ${ }^{104}$ After the evening prayers, a monk was not allowed to eat or drink on his own, ${ }^{105}$ neither was he allowed to fast or undertake any other religious practices without the abbot's permission. ${ }^{106}$

According to R.M. and R.E., the role of the superior in a monastery should be understood as being the God's vicarian ${ }^{107}$ or the Christ's vicarian, ${ }^{108}$ whose function was to be a spiritual shepherd leading the sheep-monks ${ }^{109}$ and ruling their hearts and minds. ${ }^{110} \mathrm{An}$ abbot should be more perfect than the others, which should be visible in his conduct, to be able to rule a monastery appropriately, ${ }^{111}$ as "the master of the holy art" ("sanctae huius 'artis' sit artifex") which can be performed through God and his grace. ${ }^{112}$ Therefore a subordinate was obliged to entrust all his worries to the abbot, both temporary needs - regarding food or clothing, and the spiritual ones, connected with the "future faith of the soul." 113 The superior was responsible for his decisions in front of God only, "on the

\footnotetext{
101 Eugippius, The Rule 19: CSEL 87, 34-35; ŹM 13, 172-173.

102 Eugippius, The Rule 20,8-12: CSEL 87, 36; ŹM 13, 174; cf. R.M. 55.

103 Eugippius, The Rule 20,1-4: CSEL 87, 35; ŹM 13, 173.

104 Eugippius, The Rule 20,13-16: CSEL 87, 36; ŹM 13, 174.

105 Eugippius, The Rule 22,21-23: CSEL 87, 40; ŹM 13, 178; cf. R.M. 30.

106 Eugippius, The Rule 23: CSEL 87, 40-41; ŹM 13, 178; cf. R.M. 74.

107 Eugippius, The Rule 18,60: CSEL 87, 33; ŹM 13, 171.

108 Eugippius, The Rule 25,2-3: CSEL 87, 43; ŹM 13, 181; cf. Rom 8:15; cf. R.M. 2.

109 Eugippius, The Rule 18,41: CSEL 87, 32; ŹM 13, 170.

110 Eugippius, The Rule 25,14-15: CSEL 87, 44; ŹM 13, 182; cf. Lk 12:48.

111 Eugippius, The Rule 25,1: CSEL 87, 43; ŹM 13, 181.

112 Eugippius, The Rule 25.21: CSEL 87, 45; ŹM 13, 182.

113 Eugippius, The Rule 18,49-50: CSEL 87, 33; ŹM 13, 170.
} 
The studies regarding monasticism and voluntary poverty...

day of judgment, not the one who fulfilled the orders, but the one who gave the good or bad ones will have to give a report on his conduct."114. The abbot's conduct and teaching should not go beyond the Lord's commandments, ${ }^{115}$ but rather should be "the beginning of God's justice" in himself and in other monks. ${ }^{116}$

\section{Conclusion}

In The Rule of abbot Eugippius one encounters two fundamental interpretations of the monastic obedience: the augustinian and the one according to The Rule of the Master. In the augustinian understanding of monastic obedience, an abbot should fulfill the role of the father in relation to his subordinates, (R.E. 1: 140), the earthly picture of God the Father (R.E. 1: 141), who, in his way of managing the monastery and ruling the monks, should follow the rule of service and love to fellow brothers (R.E. 1: 144; 1: 148), and in the cases when he did not know how to deal with something, he should ask a more experienced priest for advice (R.E. 1: 143). The vocation to life in obedience was a special grace of God for all monks (R.E. 1:150) which they should experience in the atmosphere of getting closer and closer to Jesus (R.E. 1: 150) and of free life choices (R.E. 1: 151). The norms of augustinian obedience repeated by Eugippius are more theologically coherent and are better acknowledged in the spiritual interpretation of appropriate fragments of the Bible.

Eugippius took the classification of obedience into the proper (with no hesitation) and improper (lazy, indolent) from the interpretation of the monastic obedience according to The Rule of the

\footnotetext{
114 Eugippius, The Rule 18,52: CSEL 87, 33; ŹM 13, 170; cf. Eugippius, The Rule 25,610: CSEL 87, 43; ŹM 13, 18; Eugippius, The Rule 25,16-20: CSEL 87, 44; ŹM 13, 170.

115 Eugippius, The Rule 25,4: CSEL 87, 43; ŹM 13, 181.

116 Eugippius, The Rule 25,5: CSEL 87, 43; ŹM 13, 181.
} 
Master. When discussing the aforementioned types of obedience in detail, Eugippius also divided it into improper (non-coenobite, Sarabaite, following the wide path and heading for damnation) and proper, that is the coenobite one, also basing his classification on R.M. According to R.M. and R.E. only coenobite obedience would have so called value deserving the eternal life. The Sarabaite obedience, on the other hand, would be regarded as improper and leading to a spiritual death of a monk. It seems that the negative opinions of R.M. and R.E. regarding the Sarabaites or the later ascetic authors took their origin from the fact of renouncing in the West the type of monasticism that was independent of the abbots' authority and that had its own, non-coeanobite ideal of monasticism as a small convent community. This is also the source of accusations formulated by the western authors of monastic rules and directed at so called Sarabaites of renouncing the coenobite ideal of obedience, renouncing the coenobite council of the elders and the authority of the abbots, what, in effect, was to lead the Sarabaites to making their own spiritual choices and swaps of monks' cells, to usurping the title of the abbot and to so called laicization (i.e. the life outside the norms of coenobium).

The coenobite obedience, clearly preferred as the most proper type, was depicted as the narrow path to heaven. For R.M. and R.E., coenobitism was the form of life indicating reformation, rejection of evil and receipt of the God's grace. Only obedience practised in compliance with the coenobite norms was the spiritual merit and should bring the eternal life. The rule of the narrow path of the coenobite obedience was to renounce any individual will or desire (either material or spiritual) and, at the same time, to subordinate completely one's own will to the decisions of the superior-abbot, as those were regarded as the will of God himself (R.E. 18: 46; 18: 64).

Obedience of so called narrow path was a form of spiritual slavery of a monk, compared to patient carrying of the burden of obedience (R.E. 18: 54), martyrdom and the trial of will (R.E. 18: 55). 
The studies regarding monasticism and voluntary poverty...

According to the authors of R.M. and R.E., the lack of any independent initiative of a monk, the complete identification of his own will with the decisions of the superior, was to have the saving power, as it would be the service leading to the eternal life (R.E. 18: 61-62). In the interpretation of the R.M. the superior-abbot was identified with the vicarian of God, Christ, who fulfilled the function of the mundane ruler of people's hearts and souls. The abbot should be more perfect than the other monks. Therefore he did not consult anybody regarding any matters (contrary to the previously quoted by Eugippius, R.E. 1: 147 augustinian Praeceptum 7:2) since, as a perfect person he had no doubts, and for his decisions he was responsible to only God on the Last Judgment day. In such a vision of Christianity, the salvation and eternal life could have been gained, in this case, by following the path of so called narrow obedience. The eternal life and heaven were not understood as the God's gift for the faithful any more or the participation in Christ's free grace given to all believers through faith and baptism. However, the obedience of a monk to the authority of an abbot undisputedly deserved heaven (R.E. 18:43).

The norms of monastic obedience quoted by Eugippius after The Rule of the Master were undoubtedly more practical than their augustinian equivalents. Unfortunately, in terms of Bible studies and theology, they seem to be half-baked. The R.M./R.E., emphasising so called spirituality of deserving the salvation, were in clear opposition to the saving evangelical kerygmat regarding the free salvation earned only by Incarnated God, Jesus Christ, for people. However, promoting the type of a Christian - monk as a slave of will, completely subordinated to the will of the superior, the norms of the R.M. repeated by Eugippius rejected the biblical vision of obedience as God's grace, given to the chosen ones, aimed at bringing the life of Jesus closer to people (paradoxically, this conception is present in the augustinian norms quoted at the beginning by Eugippius). The Rule of Eugippius, repeating the contradictory 
rules of obedience which was interpreted as the key to salvation, could not be more succesful in propagating monastic life. The Rule was created in Campania at the beginning of the $6^{\text {th }}$ century. It is a textual testimony of the synthesis of different monastic traditions, in this case an unsuccessful synthesis. The Rule of St. Benedict of Nurcia which was written a few/a few dozen years later in the same community was successful in that matter (The Rule of Eugippius 525 - 530, The Rule of Benedict - 530 - 560). 


\section{Conclusion}

From the analysed patristic texts the conclusion can be drawn that for the Fathers of the Church considering the issue of poverty the most important was the conviction that only God is the lord of everything and everybody. Two essential theological consequences result from it. Firstly, the belonging to the God's Kingdom is not equal to possessing wealth on earth. With time the due use of goods is more and more often emphasized. Secondly, if God is the absolute owner of all matter, then only the community of goods is a proper solution for the Christians being brothers to each other.

In the Christian texts of the first two centuries one does not find formal theological criteria pointing at organized asceticism or at ascetic poverty as the conditions of belonging to the Christian community. The texts of the New Testament show that each Christian can achieve perfection in Christ living in accordance with one's own form of life and according to charismas received from the Holy Spirit. The Christians of the first three centuries did not read from the Gospel teachings that faith imposes on them a duty of radical renouncement of material goods.

However, the early patristic tradition, on the basis of evangelical teachings, elaborated its own forms of realization of poverty, among which, starting from the $3^{\text {rd }}$ century in the Egyptian monasticism, only one began to be highlighted, that is the ascetic renouncement of the right to private property. In the early monastic 
222 The studies regarding monasticism and voluntary poverty...

rules the initiatory scheme of the rites of passage was gradually introduced and popularized, from the initial assimilation until the juridical inclusion of the rites of passage in the Christian monastic legislation of the Fourth century. Those rites were held according to the criterion of sex (exclusive initiation of men) and religion (the transition from the profanum to the sacrum world). The renouncement of the world took place through rejecting the right to property. In the analysed early monastic texts it is noticeable that in the $4^{\text {th }}$ and $5^{\text {th }}$ century Church the optimistic perception of the material goods, which in the $3^{\text {rd }}$ century was still well-known, disappeared. In the teachings of the Fathers' and writers' of the $4^{\text {th }}$ and $5^{\text {th }}$ century Church two essential approaches to the issue of owning property and to poverty can be distinguished: the realistic one and the pessimistic one. The first approach taught the fair way of acquiring, owning and using wealth accompanied by avoiding greed and usury. The second one propagated the ascetic approach to owning property. In St Augustine's monastic writings one can find the first ascetic doctrine in the theology of the western Church regarding voluntary poverty. Voluntary poverty of monks, in the St Augustine's interpretation, would then be ascetic poverty according to the qualitative rule: each monk was to be provided with according to his needs, adhering to the necessary minimum.

The domination of the coenobite type of monasticism affected significantly the Christian approach to the mundane goods. In the Sixth century the propagation of the realistic concept of fair acquisition, owning and using wealth disappeared in the Church. In the western Church the approach to the material property started to be perceived in the ascetic - pessimistic categories so the right to own was accepted in the case of the feudal lords while in the case of monks the analogical right became disingenuousness. In the $6^{\text {th }}$ century the gradual submission of ascetic poverty to the principal rule of obedience can be observed. Monastic poverty was then based on the absolute dependence on God and trust to his will 
expressed in the words of the abbot, and on renouncing the right to individual property, personal opinions and likes.

From the $6^{\text {th }}$ century the norms of monastic obedience were becoming more practical than evangelical. The western law makers emphasized the spiritual character of being worthy of salvation and at the same time ignored the evangelical kerygma about free salvation earned exclusively by Jesus Christ. In the rules of the $6^{\text {th }}$ century western Church also the type of a monk as a slave of will and entirely subordinated to his superior's will was promoted while the biblical vision of obedience as a grace given to the chosen one in order to bring Jesus' life closer to oneself and others was neglected. The consequences of such a slavish vision of the monastic obedience can still be found in the medieval monastic legislature. 


\section{Table of contents}

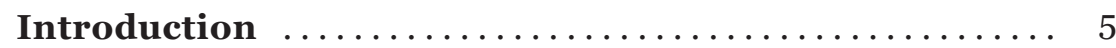

\section{The criteria of religion affiliation in the Christian} community of the first and second century $\ldots \ldots \ldots \ldots 11$

1. The criteria of orthodoxy and heresy in Judaism of the $1^{\text {st }}$ century after Christ $\ldots \ldots \ldots \ldots \ldots \ldots \ldots \ldots \ldots \ldots \ldots \ldots$

2. The criteria of orthodoxy and heresy in the New Testament $\ldots . .17$

3. The criteria of orthodoxy and heresy in the Church of the $2^{\text {nd }}$ century. Ignatius of Antioch, Justin Martyr, Irenaeus of Lyons ........................... 21

\section{The idea of poverty in the first to third century}

Church .................................. 29

1. New Testamental preaching and the ideal of consecrated

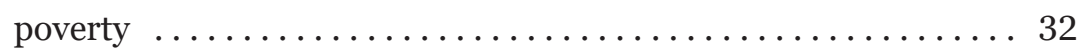

2. Forms of patristic interpretations of evangelical poverty ...... 36

3. Patristic Interpretation of Christ's poverty (First to Fourth

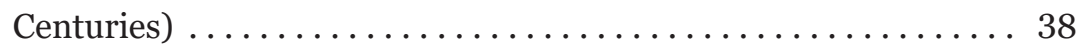


The studies regarding monasticism and voluntary poverty...

\section{Rites of passage during monastic initiation}

in the early monastic rules $\ldots \ldots \ldots \ldots \ldots \ldots \ldots \ldots$

1. Separation stage . . . . . . . . . . . . . . . 52

1.1. The initial separation - the trial at the gate $\ldots \ldots \ldots \ldots 53$

1.2. Renunciation of private property ............ 57

1.3. The clothing ceremony - the ritual of receiving the monastic garb (the habit) ............. 62

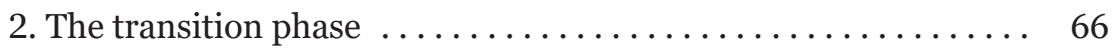

3. The incorporation phase $\ldots \ldots \ldots \ldots \ldots \ldots \ldots \ldots \ldots \ldots \ldots$

IV. Wealth and poverty in the Western Imperial Church of the Fourth and Fifth Centuries - the attempt

to synthesize the issue $\ldots \ldots \ldots \ldots \ldots \ldots \ldots$

1. The acceptance of the ownership right $\ldots \ldots \ldots \ldots \ldots . \ldots 89$

2. The destination of material goods $\ldots \ldots \ldots \ldots \ldots \ldots . \ldots . \ldots 2$

2.1. The universal destination of goods $\ldots \ldots \ldots \ldots \ldots 2$

2.2. Moderate and decent use of material goods . . . . . . . . 93

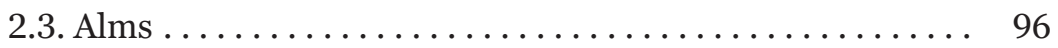

3. The criticism of the wrong usage of material goods.

Greed and usury ...................... 98

3.1. The criticism of greed $\ldots \ldots \ldots \ldots \ldots \ldots \ldots . \ldots . \ldots 9$

3.2. The criticism of usury $\ldots \ldots \ldots \ldots \ldots \ldots \ldots \ldots \ldots$

4. The Pelagian criticism of wealth $\ldots \ldots \ldots \ldots \ldots \ldots \ldots \ldots$

5 . The monastic criticism of wealth $\ldots \ldots \ldots \ldots \ldots \ldots \ldots$

V. The concept of voluntary poverty in the monastic writings of St. Augustine, the bishop of Hippo ... . . . 113

1. The early reflections of St. Augustine on monasticism and voluntary poverty $\ldots \ldots \ldots \ldots \ldots \ldots \ldots \ldots \ldots \ldots \ldots \ldots \ldots$ 
2. Augustine's mature/late reflections on the issue of voluntary

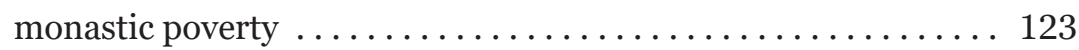

\section{The Eustathian context of the monastic poverty} doctrine in the ascetic writings of Basil the Great ..... 135

1. The pre-Basilian concepts in Asia Minor - Estathius and the Eustathian Monasticism ..................... 135

2. The concept of monastic poverty in the ascetic writings of St. Basil the Great ......................... 146

\section{An analysis of the issues related to the virtue} of poverty in the Western Church at the beginning of the sixth century. The case of the Rule of the Master (Regula Magistri) ........................... 159

1. Preliminary issues concerning the virtue of poverty in the Rule of the Master ..................... 160

2. General instructions regarding the virtue of poverty for the candidates beginning monastic life $\ldots \ldots \ldots \ldots \ldots 163$

3. Poverty as a precondition accepted during the vows

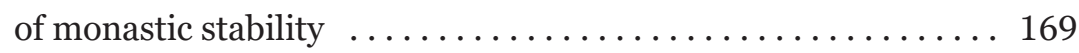

4. The juridical dimension of poverty in the Rule of the Master . . 172

5. The spiritual dimension of poverty in the Rule of the Master . . 174

\section{The Regulations concerning monastic poverty} in the rule of Eugippius (530/535) .............. 177

1. Eugippius of Noricum and his Rule ................ 177

2. The theme of monastic poverty in The Rule of Eugippius ..... 180

2.1. The Rule of Eugippius' principles concerning monastic poverty taken from St. Augustine's of Hippo Praeceptum . . 180 
The studies regarding monasticism and voluntary poverty...

2.2. The Rule of Eugippius' principles concerning monastic poverty taken from The Rule of the Master and The Rule of St. Basil . .

IX. The issue of possessing material goods in the teachings of St. Peter Chrysologus's, the bishop of Ravenna .

1. The acknowledgement of the right of property of material

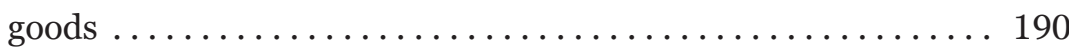

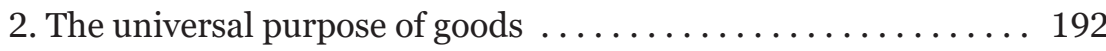

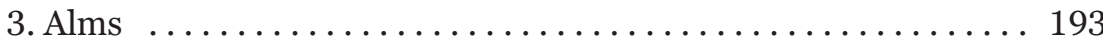

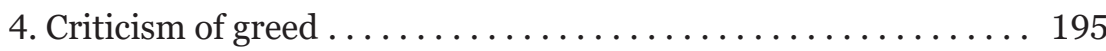

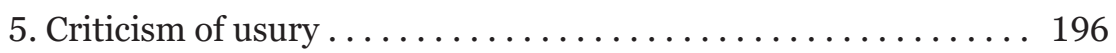

X. Monastic life as proceeding the "narrow path" of obedience according to the Rule of Eugippius . . . . . 199

1. Augustinian interpretation of monastic obedience ........ 201

2. Obedience according to The Rule of the Master . . . . . . . . . 203

2a. Undue obedience, i.e. non-coenobite (in other words: sarabaite obedience or following "the wide path") . . . . . 204

2b. The due, i.e. coenobite obedience . . . . . . . . . . 212

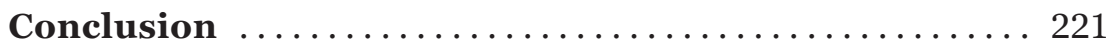

